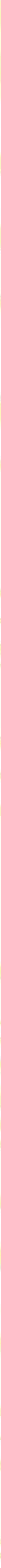




\section{ZEYTININ AKDENIZ'DEKI YOLCULUĞU}

KONFERANS BiLDiRILER i 


\title{
ZEYTININ AKDENIZ'DEKI YOLCULUĞU
}

Konferans Bildirileri

\author{
Yayına Hazırlayan \\ Ayşegül SABUKTAY \\ Yayın Koordinasyon \\ Ece AYTEKIN BÜKER \\ Ekrem TÜKENMEZ \\ Editörler \\ Alp Yücel KAYA \\ Ertekin AKPINAR
}

Grafik Tasarım ve Uygulama

Güven TOROS

\section{Afiş/Çizim ve Fotoğraflar}

İzmir Akdeniz Akademisi Arşivi-Tolga ÖZMEN-A. Ertan IPLiKÇi-Güven BAKIR

\section{Çeviri}

Ali ÇAKIROĞLU

\section{Yönetim Yeri}

IZMIR BÜYÜKȘEHIR BELEDIYESI AKDENIZ AKADEMISi

Mehmet Ali Akman Mah. Mithatpaşa Cad. No: 1087, 35290 Konak-Izmir

Tel: (0232) 2934613 Faks: (0232) 2934610

www.izmeda.org info@izmeda.org

Sertifika No: 22595

\section{Basım Yeri}

Dinç Ofset Matbaa-1145/4 Sokak No:11/C Yenişehir-iZMiR

Tel \& Fax: 023245949 61- 63 Sertifika No: 20558

Birinci Baskı: Temmuz 2016 Baskı Adedi: 1000 ISBN: 978-975-18-0198-2

íkinci Baskı: Ağustos 2018 Baskı Adedi: 1000 ISBN: 978-975-18-0241-5

Bu kitapta yayınlanan bildiriler, yazarların kişisel görüşünü yansıtır.

Bu kitap, İzmir Akdeniz Akademisi tarafından yayına hazırlanmış olup, İzmir Büyükşehir Belediyesi'nin ücretsiz kültür hizmetidir. İzmir Akdeniz Akademisi'nin, bedelsiz yayınıdır. Bütün hakları saklıdır. Kaynak gösterilmeden tanıtım için yayımlanacak yazılar dışında, İzmir Akdeniz Akademisi'nin yazıı izni alınmadan çoğaltılamaz. Satılamaz.

Copyright @ İzmir Büyükşehir Belediyesi 


\section{IÇINDEKILER}

\section{BASKI IÇîN ÖNSÖZ}

Prof. Dr. Alp Yücel KAYA Ege Üniversitesi Öğretim Üyesi

İzmir Akdeniz Akademisi Bilim Kurulu Üyesi ve Tarih Koordinatörü

\section{ÖNSÖZ}

Doç. Dr. Alp Yücel KAYA Ege Üniversitesi Öğretim Üyesi

İzmir Akdeniz Akademisi Bilim Kurulu Üyesi ve Tarih Koordinatörü

ZEYTiNiN AKDENIZ’'DEKi YoLCULUĞU-I:
13 Klazomenai Zeytinyağı İşliğinin Ayağa Kaldırılma Öyküsü

Klazomenai Zeytinyağı İşliği

A. Ertan iPLikçi Emekli Öğretmen

Prof. Dr. Güven BAKIR Ege Üniversitesi Emekli Öğretim Üyesi

ZEYTiNiN AKDENIZ'DEKi YOLCULUĞU-II:
XVIII. ve XIX. Yüzyıllarda Ege'de Zeytin ve Zeytinyağı Ticareti

İstanbul'a Zeytinyağı Gönderilmesi

Prof. Dr. Zeki ARIKAN Ege Üniversitesi Emekli Öğretim Üyesi

Dünyanın İştahını Kabartan İki Renk, Bir Kent:

"Zeytin Yeşili, Zeytinyağı Sarısı ve İzmir"

Doç. Dr. Cihan özGüN Ege Üniversitesi Öğretim Üyesi

ZEYTiNiN AKDENIZ'DEKi YoLCULUĞU-III:
Ege'de Zeytin Kooperatifçiliğinin Tarihi

Tariş Zeytin ve Zeytinyağı Tarım Satış Kooperatifleri Birliği Tarihi

Dr. Özlem YILDIRIR KOCABAŞ Dokuz Eylül Üniversitesi Öğretim Üyesi

Kırsal Kooperatifçilikte Gödence Örneği ve İzmir Kooperatifçiliğine Toplu Bir Bakış

Çağatay Özcan KOKULU Gödence Tarımsal Kalkınma Kooperatifi Başkanı

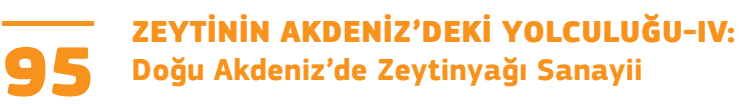

Zeytin ve Zeytinyağının Tarihselliği

Prof. Dr. Christos HADZıIIOSSIF Girit Akdeniz Araştırmaları Enstitüsü-FOR.T.H.

Erken Modern Osmanlı İmparatorluğu'nda

Zeytin ve Zeytinyağı Tüketimi

Prof. Dr. Suraiya FAROQHI İstanbul Bilgi Üniversitesi Öğretim Üyesi 


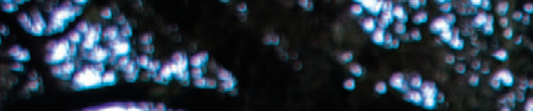

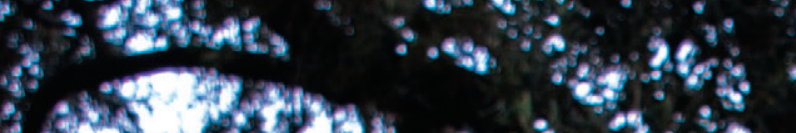

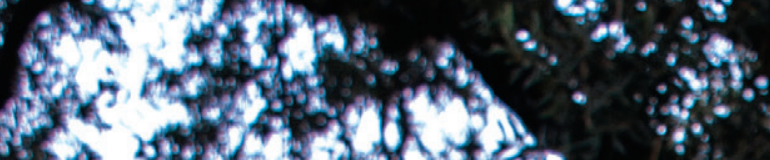

(a)

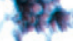

2.0. 20 .

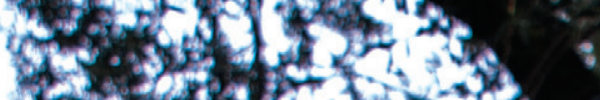

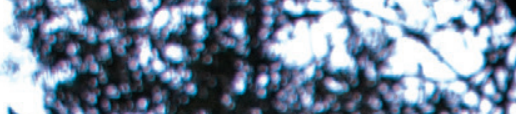

3.

s)en:
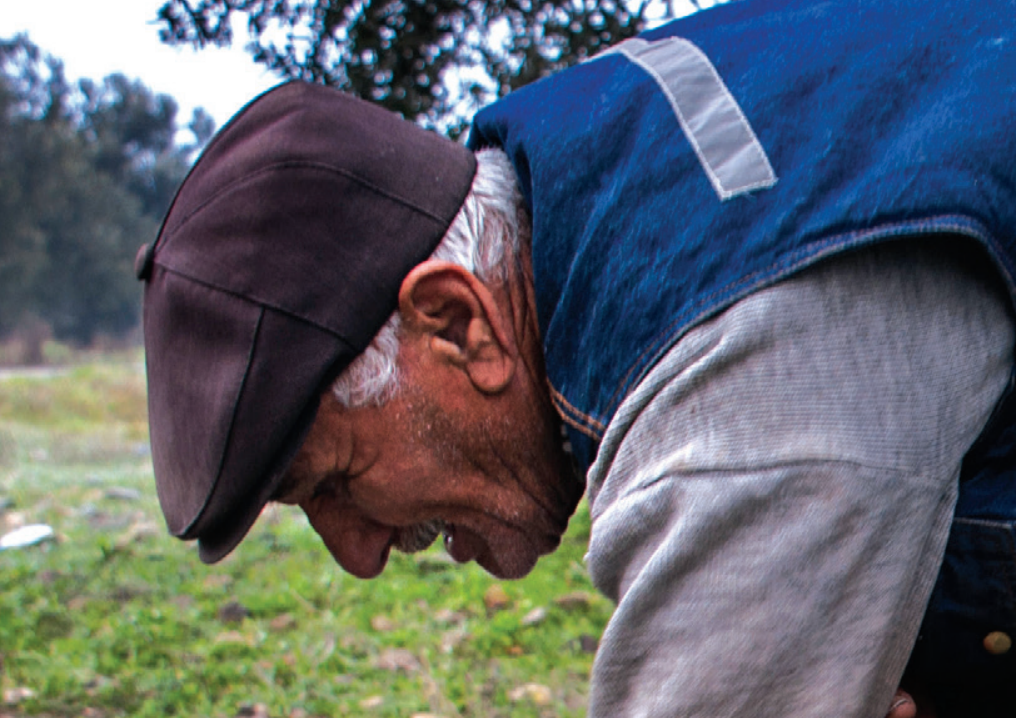

\section{0.}

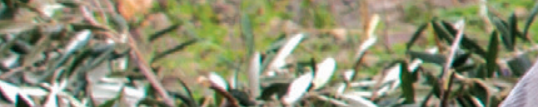

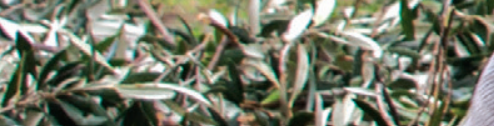

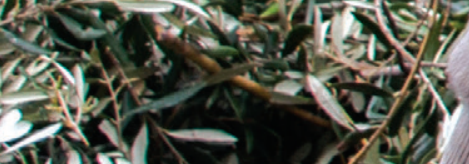

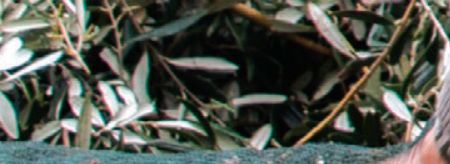

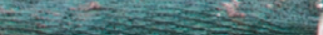

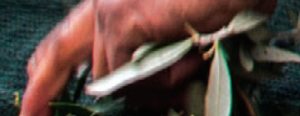

Q6.

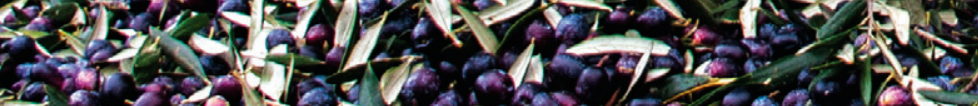

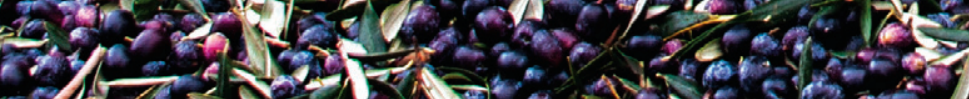

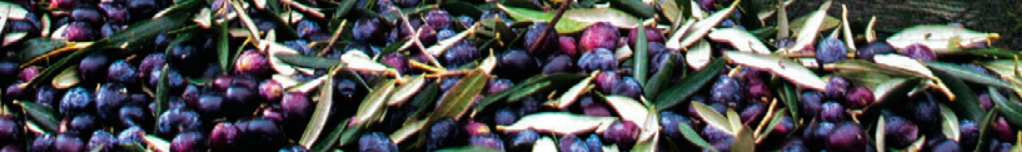

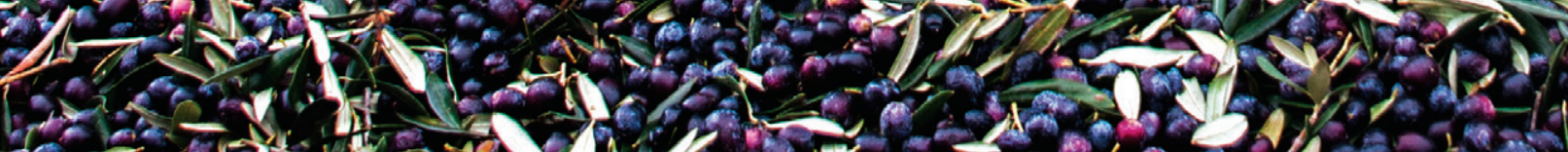

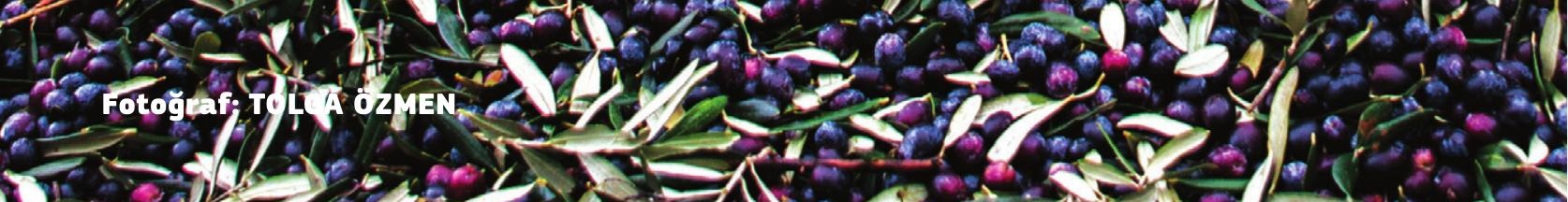




\section{Baskı İçin Önsöz}

\section{Zeytinin Akdeniz'deki Yolculuğu Mücadeleyle Devam Ediyor...}

2017 yılının Mayıs ayında, “Üretim Reform Paketi Yasa Tasarısı” başlığı altında Türkiye Büyük Millet Meclisi'ne [TBMM] sunulan “Sanayinin Geliştirilmesi ve Üretimin Desteklenmesi Amacıyla Bazı Kanun ve Kanun Hükmünde Kararnamelerde Değişiklik Yapılmasına Dair Kanun Tasarısı" zeytincilik alanında önemli değişiklikleri gündeme getiriyordu.

Kanun tasarısının 2. maddesi, "zeytinlik sahalarını, orman sınırları dışında kalan ve her bir dekar alanda, en az on beş zeytin ağacı bulunan yerler" olarak tanımlıyor ve yine 2 . maddeyle "zeytinlik alanlarının korunması, imara açılması, sanayi tesisi kurulması için illerde dokuz kişiden oluşacak Zeytinlik Sahaları Koruma Kurulu kurulması"nı öngörüyordu; 3. madde, zeytinlik alanlarda hayvan otlatılmasını yasaklıyor, daha önceki düzenlemelerdeki üç ay hapis cezasını kaldırarak, hayvan otlatanlara beş bin lira para cezası getiriyordu; 4. maddeyse 26 Ocak 1939 tarih ve 3573 sayılı Zeytinciliğin Islahı ve Yabanilerinin Aşılattırılması Hakkında Kanun'un 20. maddesini “Zeytinlik sahaları içinde ve bu sahalara en az üç kilometre mesafede zeytinliklerin bitkisel gelişmesini, çoğalmalarını engelleyecek kimyasal atık oluşturacak tesis yapılamaz ve işletilemez. Ancak, alternatif alan bulunmaması ve kurulun uygun görmesi şartıyla, bakanlıklarca kamu yararı kararı alınmış yatırımlar için zeytinlik sahalarında yatırım yapılmasına Gıda, Tarım ve Hayvancılık Bakanlığı tarafından izin verilebilir" şeklinde değiştirirken, zeytin ağacı kesenlere de ağaç başına iki bin lira ceza öngörüyordu.

Gündeme gelen tepkiler sonucu "üretim reformu" düzenlemesinden zeytinle ilgili maddeler çıkarıldı. Aslında bu 2002 yılından bu yana zeytinciliğe karşı TBMM gündemine gelen ve püskürtülen yedinci taarruz idi. Maddeler olumlu bir hava estiriyor gibi görünse de, maddelerin tersten ifade ettiklerini düşününce artık on beşten az zeytin ağacı içeren alanlar, zeytinlik niteliğini ve o niteliğin doğurduğu koruma kalkanını kaybetmiş olacak, tarım dışı çıkar çevrelerinin dahil olduğu bir kurul aracılığıyla tarım/zeytincilik dışı yatırımların, özellikle maden ve imar yatırımlarının, önü açılacak, parasını veren zeytin ağaçlarını kesebilecekti. 1939 tarihli Kanun'un 20. maddesini hatırlatmak bir taraftan zeytinliklerin var olan korunma kalkanını, diğer taraftan gündemde olan taarruzun boyutunu gösterecektir: "Zeytinlik sahaları içinde ve bu sahalara en az üç kilometre mesafede, zeytinliklerin bitkisel gelişimini ve çoğalmalarını engelleyecek kimyasal atık oluşturulacak tesis yapılamaz ve işletilemez. Bu sahalardaki zeytin ağaçlarının sökülmesi izne tâbi olup, izinlerin alınması durumunda dahi kesin zaruret görülmeyen zeytin ağacı kesilemez." 
Zeytinliklere yönelik bu taarruz Türkiye ile sınır değil. Yunanistan'da Selanik'in Halkidiki bölgesi de, zeytinliklere karşı madenciliğin kuşatması altında. ${ }^{1}$ Ama tabi ki 1939 kanununun getirdiği koruma kadar, günümüzdeki taarruzun da arkasındaki iktisadi, toplumsal ve siyasi dinamikler Akdeniz boyutunda tarihselleştirilerek tartışılmalı. Çünkü mesele yalnızca zeytini korumak veya ortadan kaldırmak ikileminden ibaret değil, toplumun farklı sınıflarının zeytin etrafındaki mücadelelerini ortaya koymak gerek. İkinci baskısını yapan bu kitap, günümüz mücadelelerini değerlendirebilmek için, zeytinin hikayesini Akdeniz'de tarihselleştirme çabasının bir ürünüdür.

Zeytinin Akdeniz'deki Yolculuğu kitabı ikinci baskısına hazırlanırken, kitaba önemli katkıda bulunan Prof. Dr. Güven Bakır'ı kaybettik. Uzun yıllar Urla Klazomenai Antik Kenti Kazı başkanlığını yürüterek, Klazomenai Zeytinyağı İşliği'nin ortaya çıkarılmasında büyük emekleri olan hocamızı saygıyla anıyoruz.

Prof. Dr. Alp Yücel KAYA

Ağustos-2018

1 Bunu, aynı bu elinizde tuttuğunuz kitapta olduğu gibi, tarihsel perspektifte inceleyen güncel bir çalışma için bkz. Basil G. Gounaris (ed.), Mines, Olives and Monasteries, Aspects of Halkidiki's Environmental History, Epikentro Publishers and PHAROS books, Selanik, 2015. 
Akdeniz coğrafyası denince ilk akla gelenler arasında, zeytin ağacı yer alır. Akdeniz toplumlarını tarih boyunca zeytin, zeytinyağı ve sabun üretimi ve tüketimiyle bir tarafta ziraattan sanayiye diğer taraftan da kırlardan kentlere bağlar. Yoksulun geçim, girişimcinin kar kaynağı olur. Küçük ve büyük üreticiler, zeytinlik sahipleriyle mülksüz tarım işçileri, yağ/sabun fabrikası sahipleriyle işçileri, üreticiler ve kooperatiflerle tüccarlar/ murabahacılar/yağhaneciler/sabunhaneciler/ihracatçılar arasındaki sınıf, çıkar çatışmalarını yansıtır... İşte bu kitap, coğrafya ve toplumları böylesine kesen zeytinin, Antik Çağlardan XX. yüzyıla Akdeniz'deki yolculuğunu konu ediniyor.

Fernand Braudel'in meşhur longue durée [uzun dönem] formülü, "plus ça change et plus c'est la même chose; plus c'est la même chose plus ça change" [aynı kaldıkça değişiyor, değiştikçe aynı kalıyor] Akdeniz'i olduğu kadar, zeytini de mükemmel anlatıyor. İ.ö. VI. yüzyılda, Klazomenai'de gerçekleşen zeytinyağı sıkımına dair teknolojik yenilik [dikey milin çevresinde dönen taşlarla zeytin ezme], bir taraftan Antik Çağ'dan bu yana ahşap teknelerde ayakla zeytin ezmenin devamlılığı, diğer taraftan XIX. yüzyılda geliştirilen buharlı zeytinyağı preslerinin varlığına rağmen kendisine, XX. yüzyıla kadar uygulama alanı bulabilmiştir. Doğayı dönüştürme yönünde Antik Çağ'da ortaya çıkan teknolojik yenilikleri, Ertan İplikçi ve Güven Bakır’ın beraber kaleme aldıkları ayrıntılı makaleden öğrenebiliyoruz ama Christos Hadziiossif'in de altını çizdiği gibi, Orta Çağ'daki zeytinyağı teknolojisine dair bir şey bilmiyoruz; rahatlıkla izleyebildiğimiz XIX. ve XX. yüzyıllardaki gelişmelerse, bize zeytinyağı teknolojisinde çok büyük sıçramaların söz konusu olmadığını gösteriyor.

Suraiya Faroqhi'nin makalesinde vurguladığı gibi, aslında zeytinyağı üretimi ve tüketimine dair bildiklerimizde de Antik Çağ'la, XIX. yüzyıl arasında büyük boşluk var. Faroqhi'nin yaptığı incelikli araştırma sonucu, XIX. yüzyıla kadar zeytinyağının pek de Antik Çağ'daki önemine sahip olmadığı anlaşılıyor. Bu da aslında bize, teknolojideki durağanlığın nedenini göstermiyor mu?

Bu kitaptaki araştırmalardan ortaya çıkan bir başka sonuçsa, zeytinin kapitalizmin gelişimiyle birlikte yeniden önem kazandığı, teknolojik gelişmelerin [ilk önce buharlı makineler sonra otomasyonun hakim olduğu kontinü makineler] verimlilik baskısı altında, yüzyıllar sonra ilk defa zeytinyağı teknolojisinde çok büyük de olmasa sıçramaları gündeme getirdiğidir. Bu süreç, karlılık arayışı çerçevesinde ürünler arasındaki rekabetle birlikte gündeme gelmiştir. XVIII. yüzyılda Girit'teki üzüm ve zeytin, XIX. yüzyıl Anadolu'sunda zeytin ve susam, XX. yüzyılda zeytin ve orman, XXI. yüzyılda zeytin ve tütün 
ya da maden ve zeytin rekabetleri her dönemin ekonomik konjonktürüne bağlı olarak, hep birinciler lehine gelişim göstermiştir. Girişimci sermayedarlar, bazen zeytin lehine bazen de aleyhine yatırım yapmışlar; lehine yatırım yapanlar zeytin ağacı ziraatından, yağhane ve sabunhaneye kadar uzanan dikey bir yapılanmaya gitmişlerdir. İlk önceleri Akdeniz coğrafyasında, sonraları Akdeniz coğrafyası dışına ihracatta söz sahibi olmuşlardır.

Cihan Özgün'ün makalesinde tartışıldığı üzere, ticari ve sanayi sermayenin XIX. yüzyıl sonundan itibaren bu şekilde yoğunlaşması, küçük üreticilerle girişimci sermayedar arasındaki ilişkiyi aracı katmanları da dahil ederek tefeciliğe kadar uzanan borçluluk ilişkisine çevirmiştir. Zeki Arıkan'ın makalesi, Midilli ve Ayvalık'taki bu gelişmeleri, Namık Kemal'in ince gözlemleriyle aktarmaktadır. Bu sürece karşı, üreticilerin kooperatifleşerek mücadele etmeleri gecikmemiştir, XX. yüzyılda Midilli'deki Agia Paraskevi, İzmir ve Aydın'daki Tariş Zeytinyağı Kooperatifleri buna en iyi örneklerdir. Hatta ithal ikameci kalkınma politikalarının izlendiği II. Dünya Savaşı sonrası yıllarda, Özlem Yıldırır Kocabaş'ın makalesinde görüldüğü üzere tüm tarım sektörü gibi zeytincilik de üreticilerin örgütlendikleri kooperatiflerle desteklenmiştir.

Kapitalist ekonomi içerisinde işlese de dayanışmayı içinde barındıran kooperatifler, küçük üreticilikle birlikte 1980’ler sonrası güç ve kalkınma politikalarında mevzi kaybetmiştir. Çağatay Özcan Kokulu'nun yazısında altını çizdiği gibi özelleştirme ve bireyselleşme, günümüzde de dayanışma ve kolektif üretime karşı sınırsız bir taarruz içerisindedir, kooperatiflerse bu sürece direnmeye çalışmaktadır.

Günümüzde de büyük girişimciler kar, küçük üreticiler geçim peşinde zeytincilik yapmaya devam ediyorlar. Hatta her iki kesimin de etkisiyle, 2000'li ylllarda Türkiye'de zeytin ağacı sayısı önemli ölçüde artış gösterdi. Ama yine aynı dönemde, zeytinlik alanların tarım dışı kullanıma açılmasını sağlayacak bir mevzuatın da yürürlüğe konulması karlılığı başka alanlarda arayan sermaye tarafından zorlanmakta.

Kitapta, XVII. yüzyılda Evliya Çelebi'nin dikkatini çeken aynı zamanda İstanbul iaşesinde de ön plana çıkan, Karaburun'un işlem görmeden ağacın dalında olgunlaşarak fermante olan, 'hurma zeytini'nden de bahsediliyor. Diğer taraftan biliyoruz ki, sonraki yüzyıllar boyunca yerelliğe hapsolmuş hurma zeytin, günümüzde madenlere ve RES'lere [Rüzgar Enerjisi Santralleri] direnerek yerellikten ve unutulmuşluktan çıkıp kendisine Akdeniz'de yeniden bir yer ve yol arıyor. Bu çelişkili ve çatışmalı süreçlerin hükmüne rağmen, bu kitapta gördüğümüz gibi zeytin ağacı ve zeytinin Akdeniz'deki mücadele dolu yolculuğuna devam ediyor.

Doç. Dr. Alp Yücel KAYA

Temmuz-2016 
Shen H

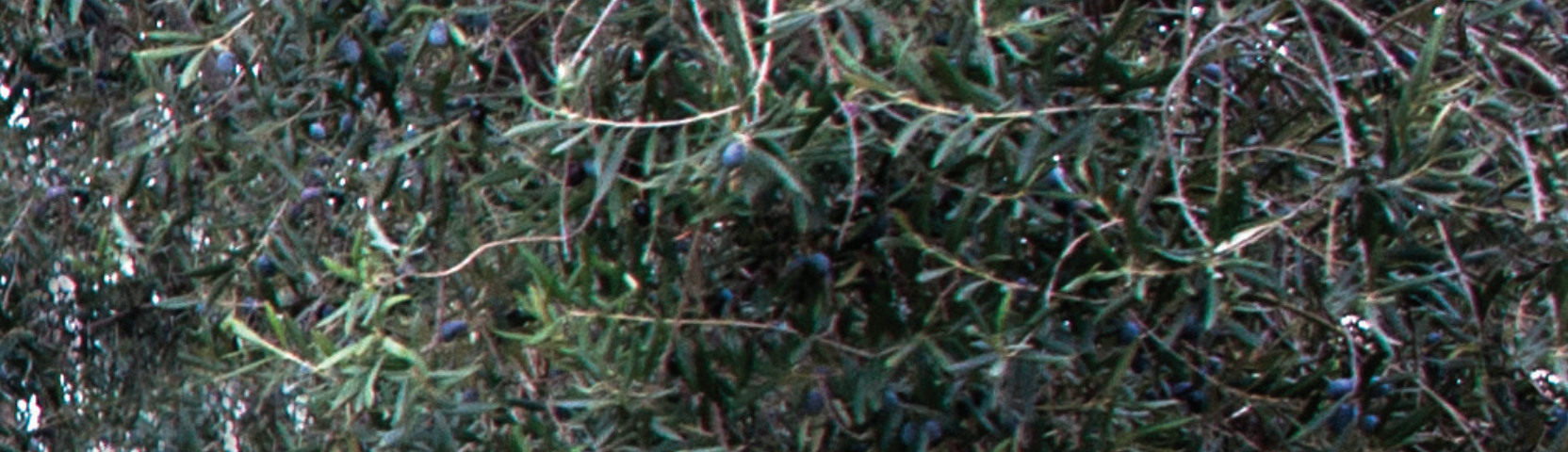
H. 3.120 (3)

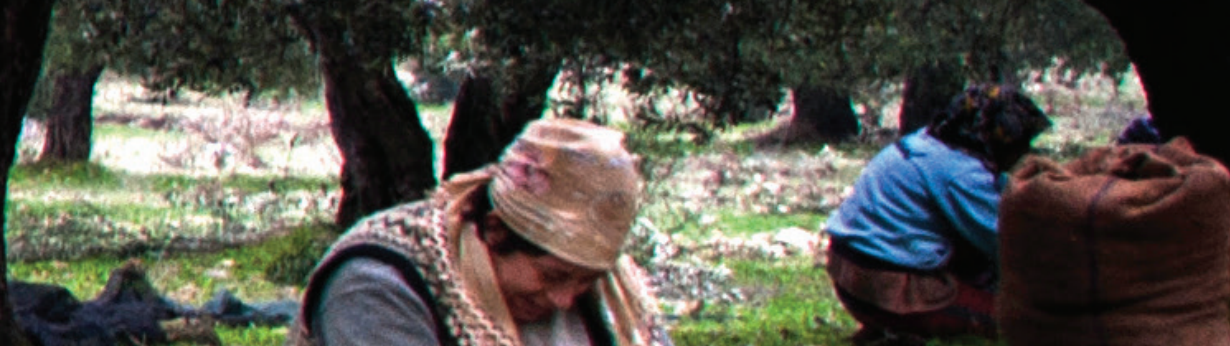

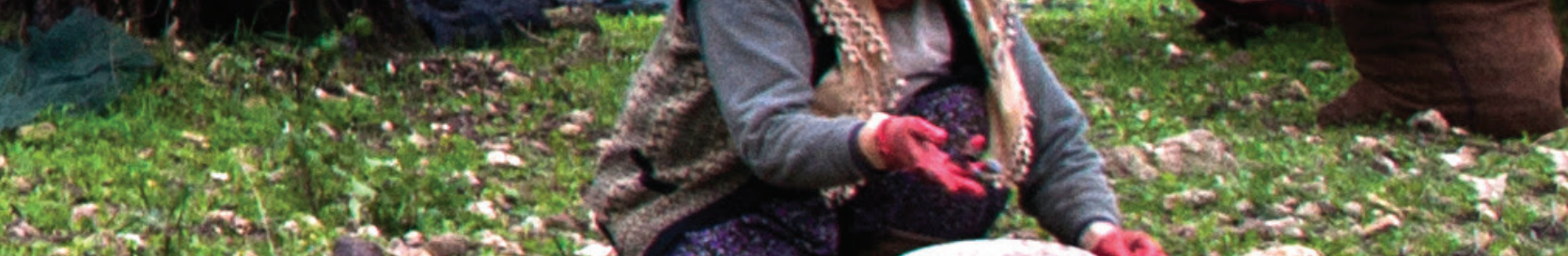
-

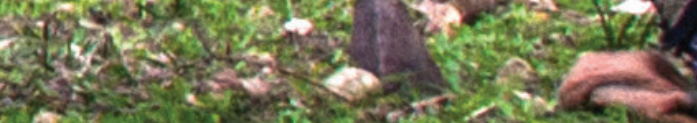

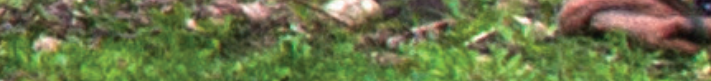
(n) xis

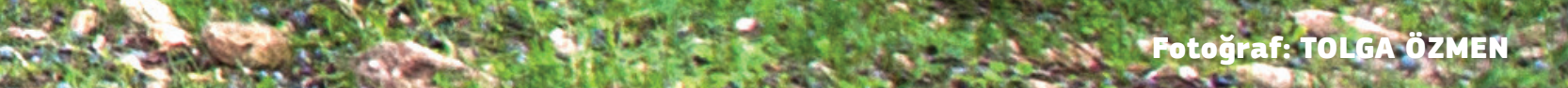

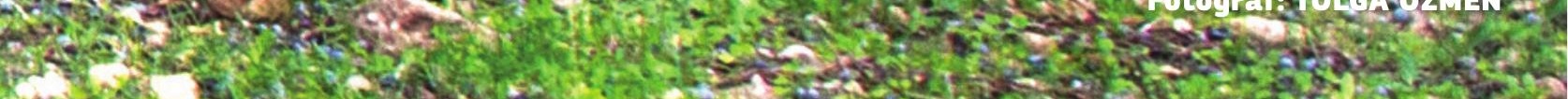





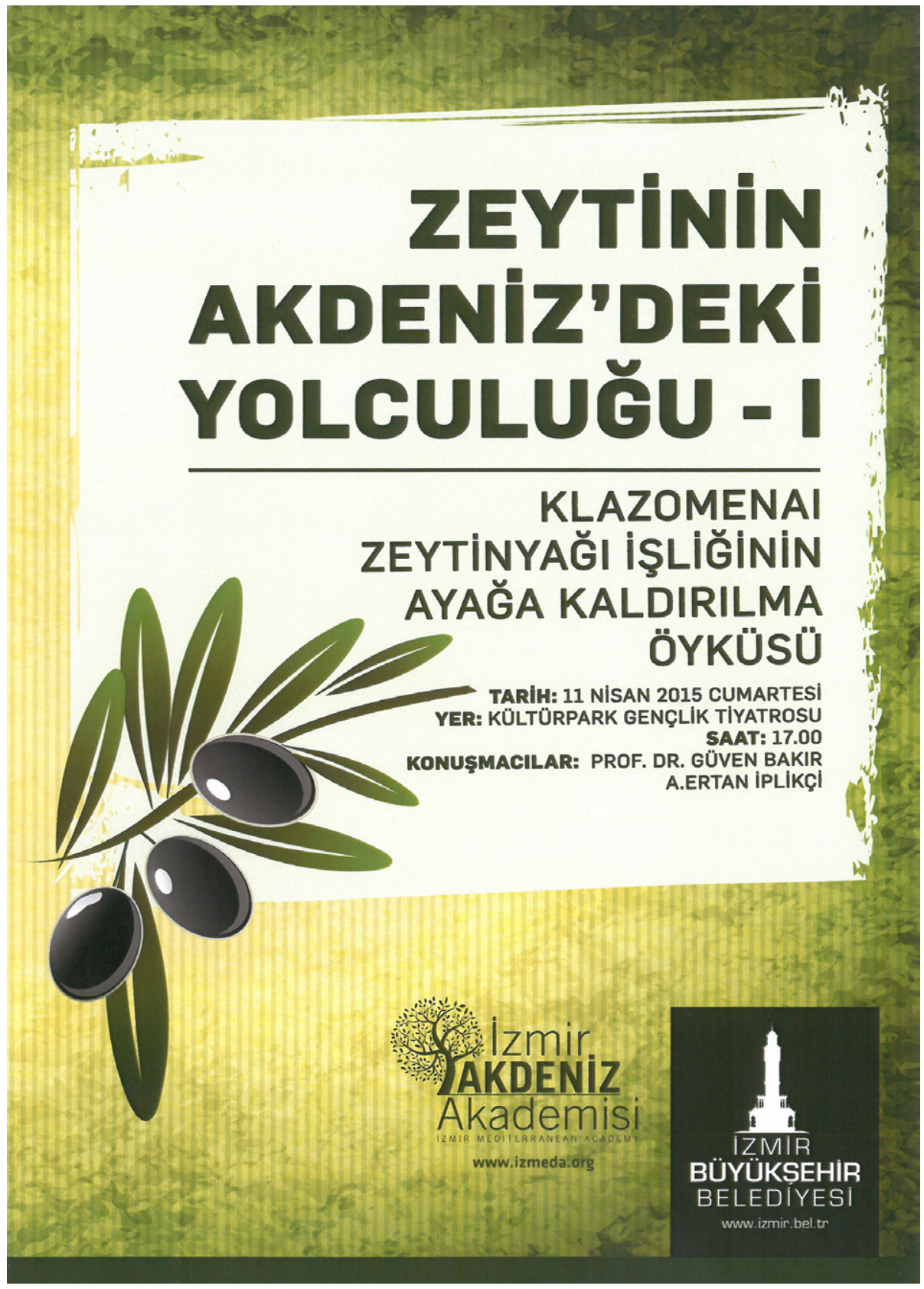





\section{Klazomenai Zeytinyağı İşliği}

\section{A. Ertan iPLikçi-Güven BAKIR}

Emekli Öğretmen-Ege Üniversitesi Emekli Öğretim Üyesi

Eski Çağ'da zeytin ağacı, kültür bitkileri arasında en değerlisi kabul edilirdi. Eski Çağ'ın barışçıl yarışmalarında galip gelenler ve bunun yanı sıra savaşlarda kahramanlık gösterenler, zeytin ağacının dalından örülmüş çelenklerle ödüllendirilmişlerdir. Toplumların zenginlikleri ve refahları zeytine bağlı olmuştur. Meyvesi vazgeçilmez bir besin kaynağıdır. Aydınlatmanın ana maddesidir. Vücudun yağlanmasında ve parfüm yapımında kullanılan zeytinyağı, cilt bakımının en önemli ve çok değer verilen bir maddesi, ayrıca ölü gömme törenlerinin ve dini törenlerin başta gelen bir unsuru olmuştur. Diğer ülkelerle yapılan ticarette, kendisinde bulunmayan bir malın karşı taraftan sağlanmasında zeytin ürünleri her zaman kabul gören bir takas maddesi niteliğine ulaşmıştır.

Romalı şair Vergilius, meyvelerinin verimli, etli ve barışa adanmış olmasından dolayı insanların zeytinle beslenmeleri gerektiğini vurgularken, ondan yaklaşık doksan yıl sonra, M.S. 60 yılında Romalı tarım uzmanı Columella, diğer ağaçlar arasında zeytini en ön sıraya yerleştirmektedir. Zeytinyağının insan sağlığındaki yeri eskiçağlarda da bilinmekteydi. "İnsan vücuduna iyi gelen iki tür sıvı vardır", diyor Romalı yazar Plinius, "içsel olarak şarap, dışsal olarak da zeytinyağı; her ikisi de ağaçlardan elde ediliyor, ama zeytinyağının yeri bambaşka".

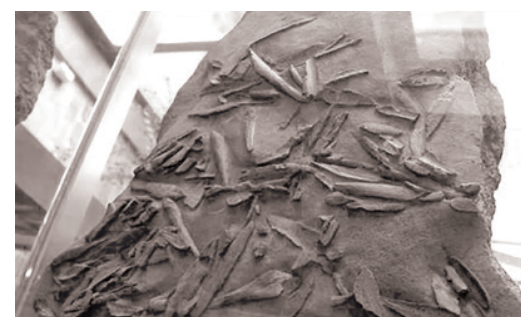

Karbonlaşmış Zeytin Sepeti M.Ö. VI. Yüzyıl
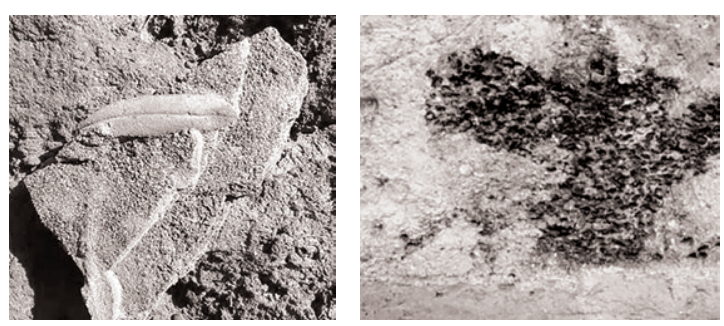

Thera'dan Zeytin Yaprağı Fosilleri

Akdeniz'i kapsayan zeytin ağacının geçmişiyle ilgili bir araştırmada geç miyosen döneminde, Türkiye'nin güneyinde yabani zeytin olduğu söylenmektedir. Özellikle İsrail, Kıbrıs ve İtalya'da zeytin ağacı üzerine yapılan bilimsel araştırmalar, Akdeniz havzasının doğasında günümüzden bir milyon yıl önce, 3. Jeolojik Zaman'da yabani zeytin ağacının bulunduğunu belirlemiştir. Bologna yakınlarındaki Mongardino'da, açığa çıkarılan fosil yapraklar bunun bir kanıtı olarak gösterilmektedir. İsrail'de, Har Hanegev'deki paleolitik merkezlerde yapılan kazılarda, M.0̈. 45000 ve M.0̈. 25000 yıllarına tarihlenen tabakalarda 


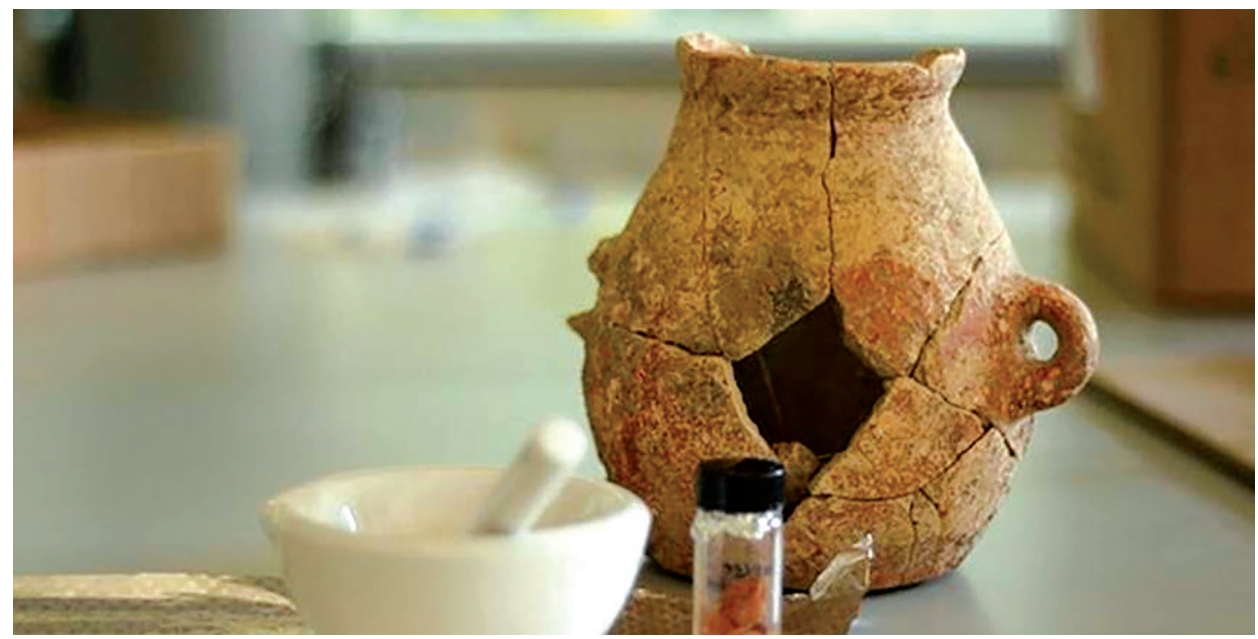

İsrail'de, En Zippori Bölgesinde Çıkan kap.

İ̧̧inden Alınan Örneklerin Analazi, Zeytinyağının M.Ö. 5800 yıllarına ait olduğu gösterildi

yabani zeytin odunu kalıntılarına rastlanmıştır. İnsanların yerleşik düzene geçtikleri, ancak henüz seramik üretiminin başlamadığı döneme tarihlenen birçok merkezde de, M.ö. 8000 yıllarından itibaren kömürleşmiş zeytin çekirdekleri açığa çıkarılmıştır. İtalya'da, Bari'nin güneyinde Torre Canne'de ele geçen buluntulara göre zeytin meyvesi, günümüzden 7000 yıl önce bu bölgedeki insanlar tarafından besin olarak tüketilmiştir.

Açığa çıkarılan buluntulara dayandırılan bugünkü genel kanıya göre, insanın yabani zeytin ağacına müdahale edip onu ıslah etmesinin, daha verimli bir kültür bitkisine dönüştürmesinin ve giderek zeytin meyvesinin içerdiği yağı elde etmeye yönelik girişimlerde bulunmasının, kalkolitik dönemde, günümüzden yaklaşık 7800 yıl önce Doğu Akdeniz kıyılarına komşu topraklarda başladığı kabul edilmektedir.

İsrail'in kuzeyindeki En Zippori bölgesinde, 2011 yılında başlayan anayol çalışmaları esnasında ortaya çıkarılan tarihi eserlerden yirmi tanesinin analiz sonuçlarında, zeytinyağı kalıntılarına ulaşılmıştır. Alınan örneklerin analizi, zeytinyağının M.0̈. 5800 yıllarına ait olduğunu göstermiştir.

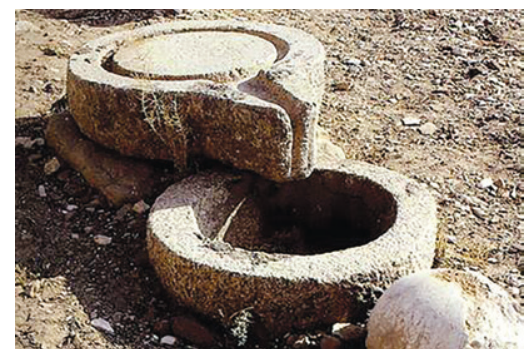

Medinet Habu'da Zeytin Presi M.Ö. XII. Yüzyıl

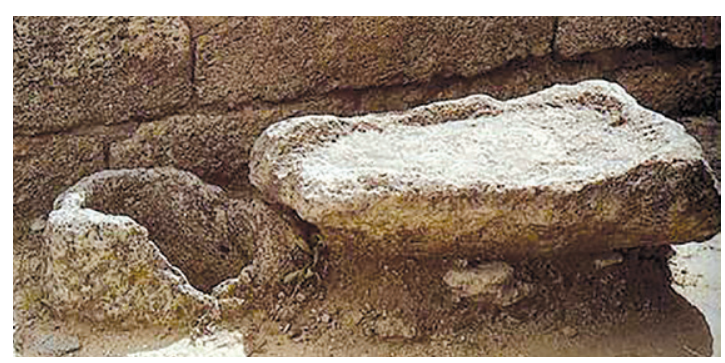

Girit’te Zeytinyağı Presi M.Ö. XVII. Yüzyıl 
Girit saraylarının işliklerinde görülen zeytinyağı üretimine işaret eden buluntular, bu yeni teknolojinin M.ö. 2000-1500 yılları arasında Girit’te uygulanmakta olduğunu göstermektedir.

M.0̈. 1500-1100 yılları arasında Mısır, Doğu Akdeniz, Kuzey Ege Denizi ve Güney İtalya arasındaki dünyada görülen Myken etkinlikleri, islah edilmiş zeytin ağacının ve zeytinyağ elde etme teknolojisinin batıya doğru yayılmasında ikinci dalgayı oluşturmuştur.

Akdeniz'de Tunus, Sardinya ve İspanya, Atlantik Denizi'nde de Fas ve yine İspanya sahillerinde, M.Ö. 1000 yıllarında başlayan Fenikelilerin koloni kurma hareketleri, bu yayılmanın alanını Akdeniz'in batı ucuna ve hatta Atlantik Denizi'nin, Akdeniz'e komşu kıyılarına ulaştıran bir üçüncü yayılma dalgasıdır.

M.Ö. VIII. yüzyılda, Ege Denizi kıyılarında oturan halkların, aracısız olarak kendilerinin Doğu kültürleriyle ilgilenmeye başlamaları, oralara bir yandan ticaret yapmak, bir yandan paralı asker olarak çalışıp para kazanmak, diğer bir yandan da koloniler ve ticaret merkezleri kurmak amacıyla gidip gelmeleri sırasında, bir çok doğulu unsur Ege dünyasına girmiştir. Ege Denizi insanlarının bu girişimleri, onlara ıslah edilmiş zeytin ağacı ve aradaki zaman dilimi içinde oralarda gelişen zeytinyağı üretimine yönelik teknolojilerle, dördüncü defa tanışma fırsatı vermiştir. Bundan sonraki dönemlerde, o günkü dünyanın küçülmesi, özellikle Hellenistik ve Roma dönemlerinde ilişkilerin artması, bunun da ötesinde işgaller, doğuyla batıyı birbirine iyice yaklaştırmış ve çok eski zamanlardan beri doğada yabani olarak bulunan zeytin ağacının kültür bitkisine dönüştürülmesi girişimleri yaygınlaştırmış ve böylece de zeytinyağı elde etmeye yönelik bilgiler Akdeniz insanlarının ortak malı olmuştur.
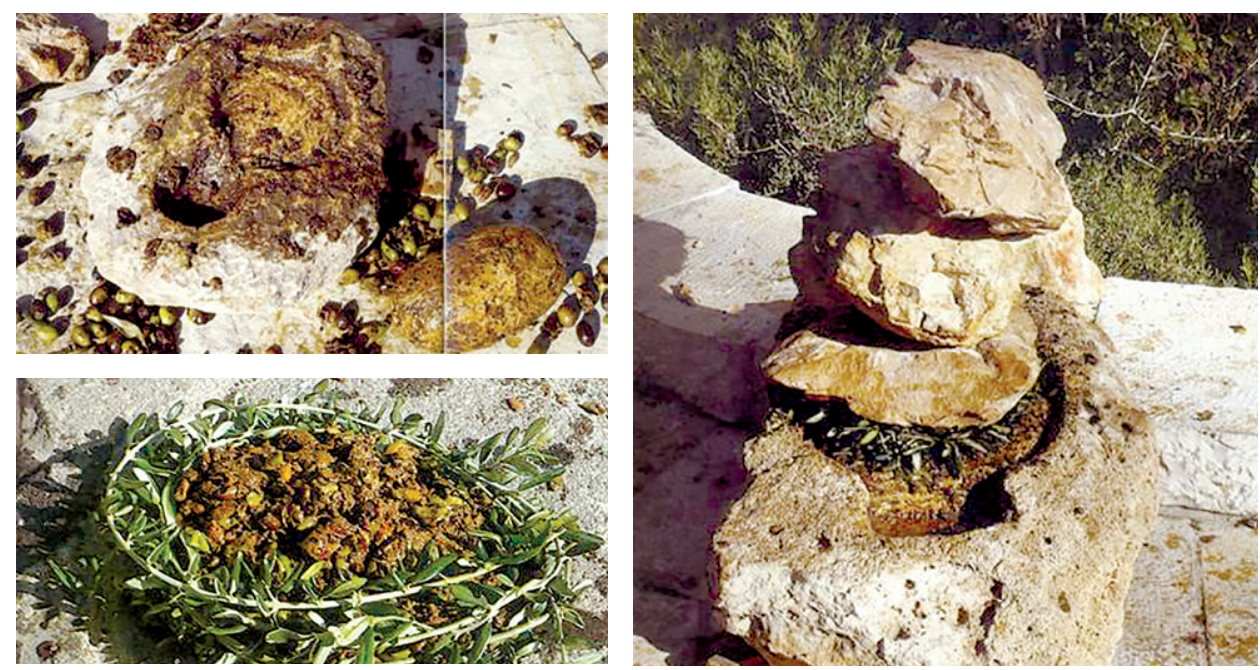

M.Ö. 5800 yıllarından günümüze kadar her dönemde kullanılan, basit ve taşınabilir zeytin havanlarında da yağ elde edilebiliyordu. 
Zeytinyağını elde etmenin basit yolu, zeytini bir taşla vurarak ya da ezerek hamur haline getirdikten sonra elde sıkıştırarak, zeytin meyvesinin suyunu çıkarmak, bir süre bekledikten sonra kara suyun üstüne çıkan zeytinyağını almaktır.

Düz bir zemin üzerinde silindir şeklindeki taş yada taşlarla zeytinin hamur haline getirilmesi ve basit preslerde içindeki yağın çıkarılmasının tam olarak tarihi verilememekle birlikte Girit’te, Geç Bronz Çağı yerleşimi olan Palaikastro'da saptanan taş bir zemin, üzerinde silindir biçimli bir değirmen taşının kullanıldığı bir 'pres yatağı' olarak yorumlanmaktadır.

Günümüzde de çevre olanaklarının yetersizliğinden birçok yerde ilkel diyebileceğimiz yöntemlerle zeytinyağı yapılmaktadır.

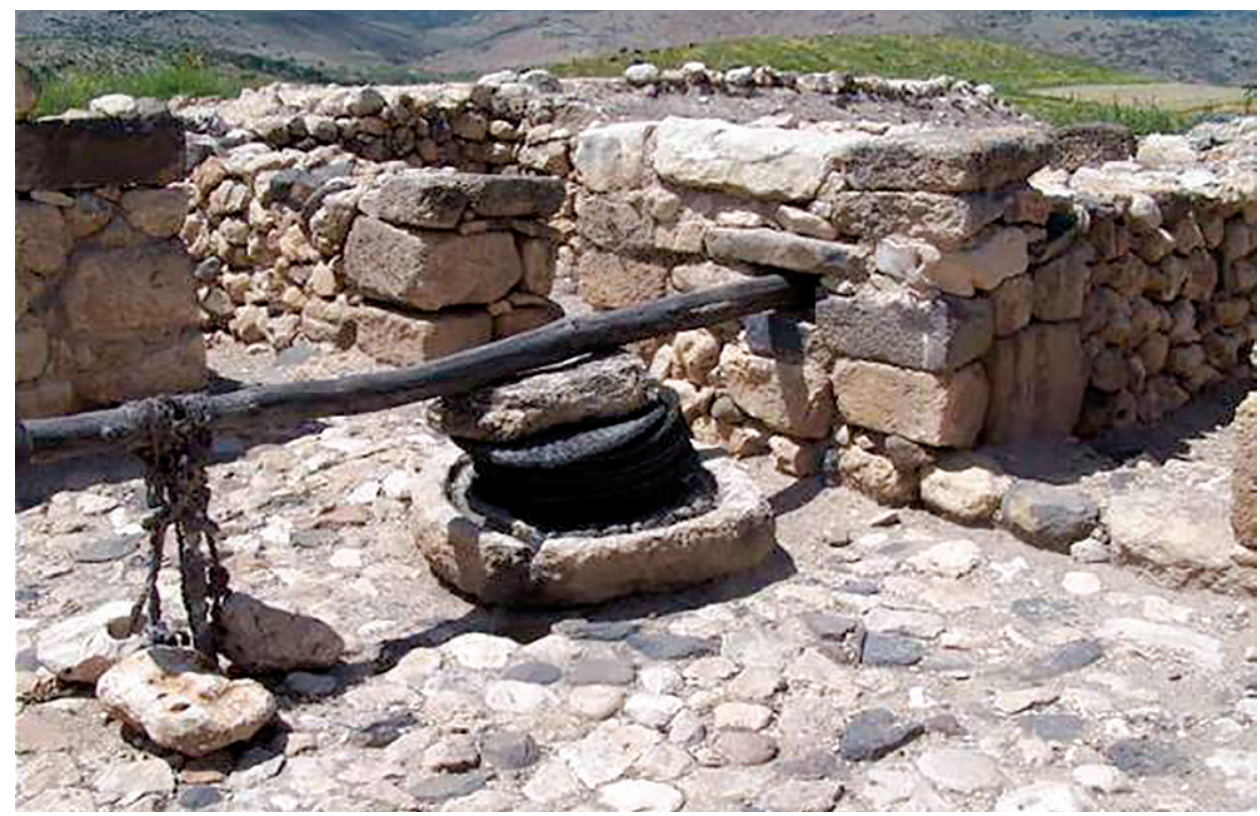

Basit Pres

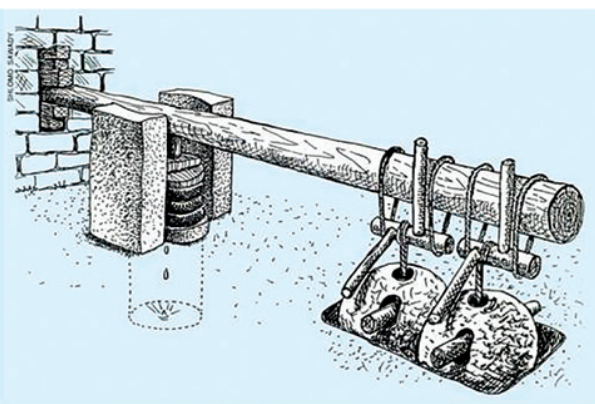

İsrail'de Güney Tipi Zeytinyağı Presi

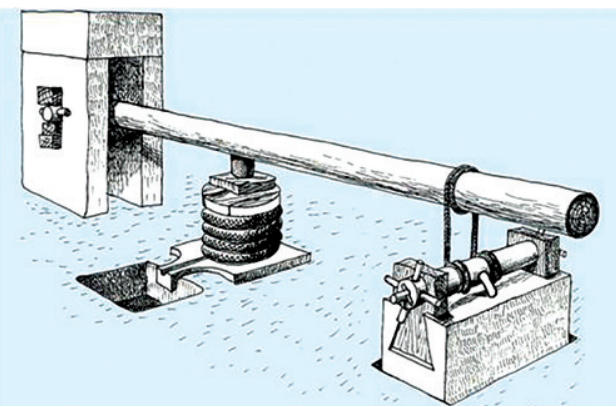

İsrail'de Kuzey Tipi Zeytinyağı Presi-Roma Dönemi 


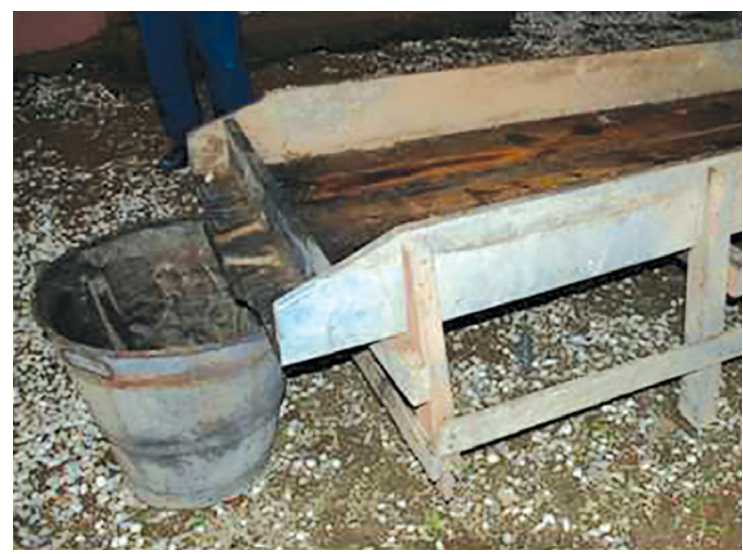

Günümüzde çevre şartlarında kaynaklanan nedenlerle, basit kırma sistemleriyle zeytinler hamur haline getirilmekte ve içindeki zeytinyağı alınmaktadır.

Bu Sistemde 2013 yılında zeytinyağı elde edilmiştir.

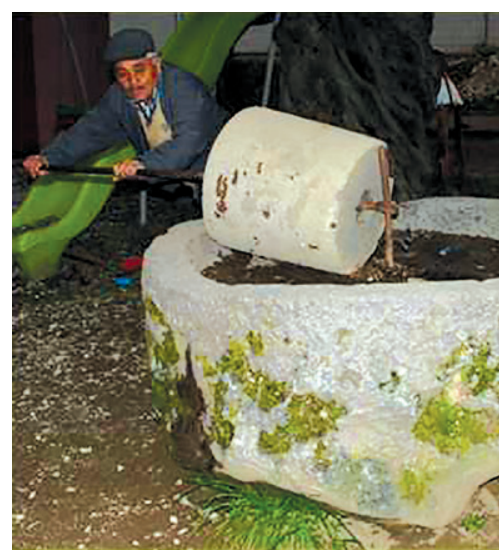

Ayak Yağı elde etmek için kullanılan düzenek (Sıkına ve polüm)

İzmir, Menderes, Ataköy

\section{Klazomenai İşliği}
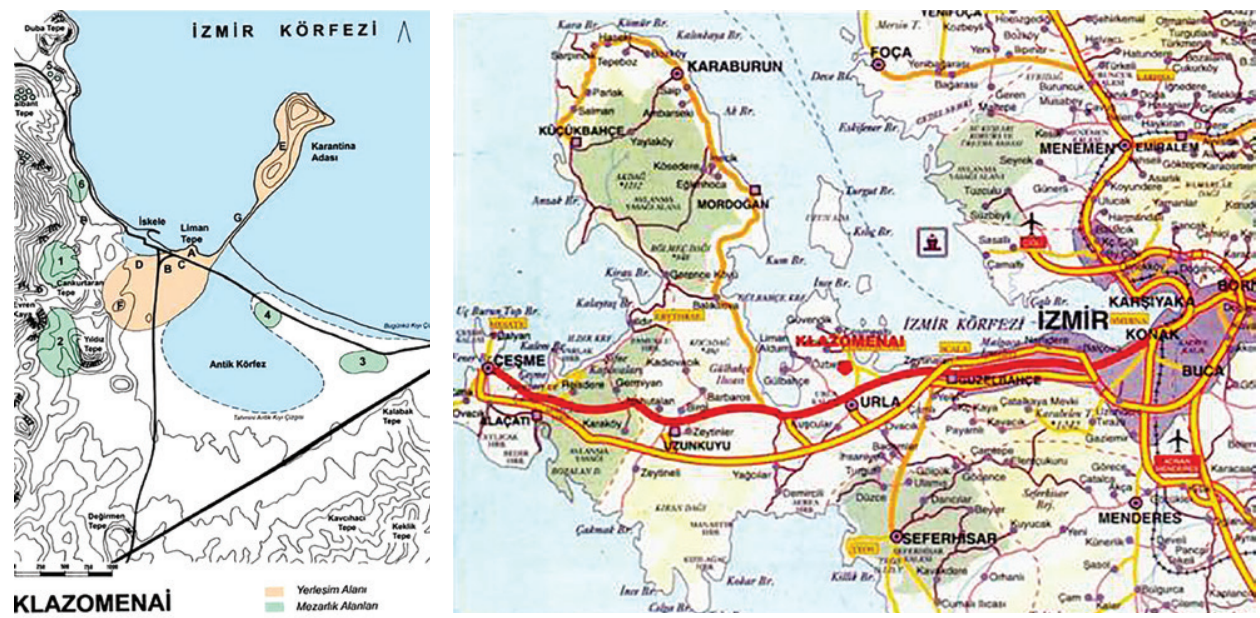

Klazomenai Antik Kenti-Konum

1992-2004 yılları arasında yürütülen kazı çalışmaları sırasında Hamdi Balaban Tarlası mevkiindeki Klazomenai işliği, içinde kendi dönemine ait küçük buluntularla birlikte açığa çıkarılmıştır. İki kullanım evresi olan zeytinyağı işliği kazılarında, iki depo ve iki kuyu ortaya çıkarılmıştır. Zeytinyağı işliğinin -benzerleri M.ö. 630’larda Akdeniz'in doğu ülkelerinde görülen- birinci kullanım evresi M.Ö. VI. yüzyılın başlarında kurulmuş ve M.0̈. 546'da, Persler'in İonya'yı işgaliyle terk edilmiştir. İkinci kullanım evresi M.ö. 530/520'de, birinci kullanım evresine ait ana kayaya oyulmuş altyapı çukurlarının doldurulup, yeni 
altyapı çukurlarının açılması ve bu çukurların üzerine dönemine göre yenilikçi araçların yapılmasıyla tekrar açılmıştır. İkinci evre işliği, M.Ö. 500/490'da Persler'in İonya ayaklanmasını sert bir şekilde bastırmasıyla kapanmıştır. M.Ö. IV. yüzyılda işliğin bulunduğu alan üzerine inşa edilen büyük bir yapılar için gerekli tesviye çalışmaları sırasında, kaya içine oyularak yapılan tesisin içi doldurulmuş, üzeri örtülmüş ve kayaya oyulmuş alt yapısı bu şekilde günümüze kadar korunup gelmiştir.

\section{İşliğin Kazısı}

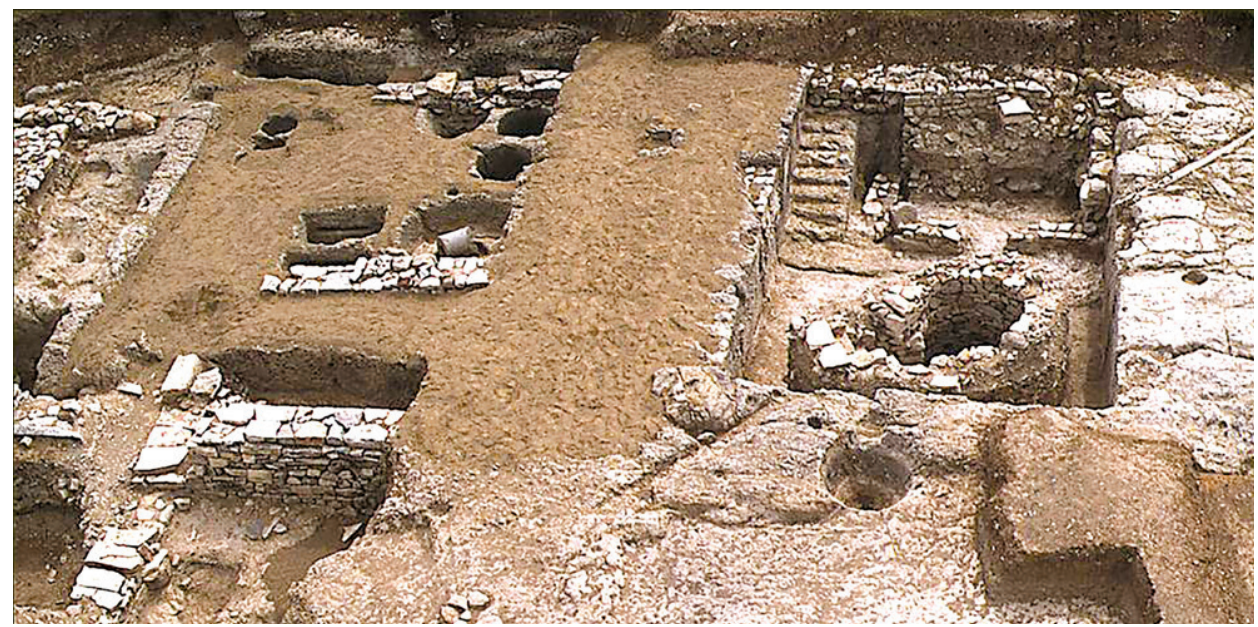

Klazomenai Antik Zeytinyağı İşliğinin Kayaya Oyulmuş Çukurları

İşliğin merkezi durumundaki üretim bölümü, anakayanın yontularak derinleştirilmesiyle elde edilmiş, içine batıdaki açık alandan bir basamak merdiveniyle inilen, düzensiz şekilli bir dörtgen mekandır. Bu mekan içinde, yine anakayanın oyulmasıyla elde edilmiş, çeşitli derinlik ve şekillerde -dolayısıyla çeşitli işlevlere sahip- on beş çukur saptanmıştır.

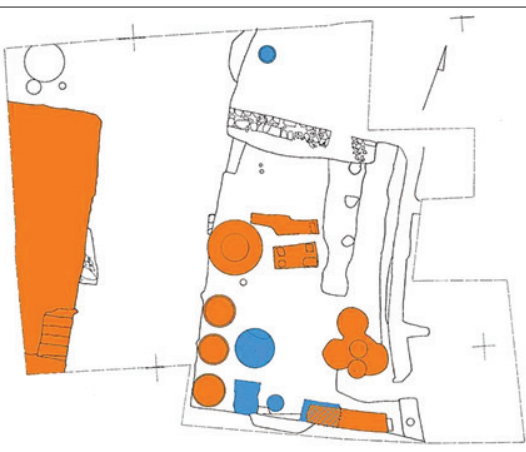

Mavi renkli alanlar 1. evreyi [M.Ö. 580-550] göstermektedir.

Turuncu renkli alanlar 2. evreyi [M.Ö. 530/520-500/490] göztermektedir. 
Çukurların işlevleri göz önünde tutulduğunda, sayının çokluğu ve aynı işlevi görebilecek, ancak zeytinyağı üretim işliğinde bir tane olması gereken bir araç için birden fazla altyapı oluşturulmuş olması, bu işlikte iki değişik sistemin bulunduğu izlenimini uyandırmıştır. Bu izlenimden yola çıkılarak, çukurların doldurulmasında kullanılan malzemenin niteliğiyle içerdiği seramik gibi küçük buluntular incelenmiş ve çukurların tümünün aynı anda doldurulmadığı ortaya çıkmıştır. Böylece işlikte, iki kullanım evresinin varlığı saptanmiştır.

\section{Evre}

Üretim bölümü planında mavi renkle vurgulanan çukurların, işliğin l. evresine ait oldukları anlaşılmaktadır. Her üç çukur, M.Ö. VI. yüzyıl içersinde doldurulmuş, diğer bir deyimle kullanımdan çıkarılmışlardır.

İlk evreye ait çukurlar arasında, biri baskı kolunun uç kısmının dayandığı ahşap dikmelerin yerleştirilmesi için oyulmuştur. Çukurun karşılıklı her iki yan duvarına yatay olarak oyulmuş oluklara yerleştirilen kalasların baskı kolu ucunun dayandığı dikmelere bağlanmasıyla, baskı sırasında yukarıya doğru çekilmeye zorlanan dikmelerin yuvalarından çıkması önlenmiştir. Dikmeler için açılmış çukurun dar olmasına bakıldığında, bu preste tek parçalı, düz bir baskı kolunun kullanıldığı anlaşılmaktadır.

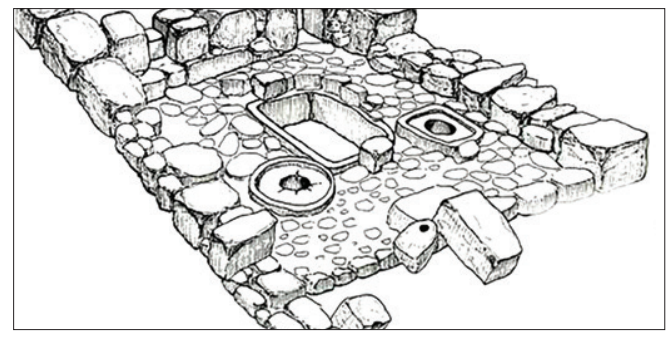

Tel Batash-Timnah

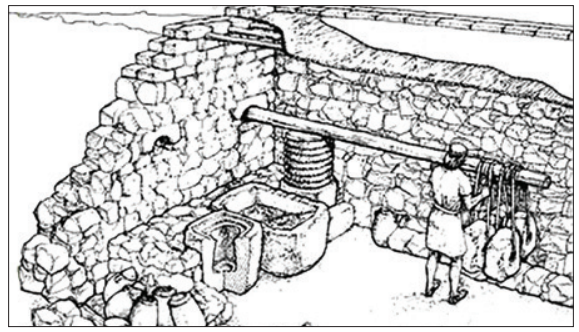

Tel Migne-Ekron

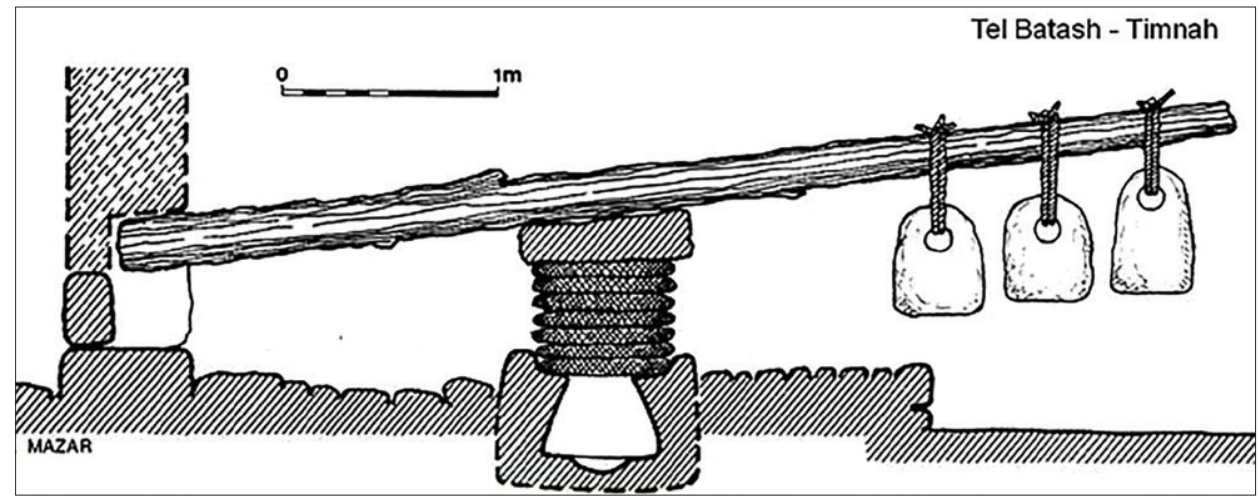

Illk Zeytinyağı İşlikleri M.Ö. 700-600 Yılları Arası/Israil 
Doğu Akdeniz havzasında, İsrail ve Kıbrıs'taki benzer işliklerde baskı kolunun ucu, taştan özel olarak yontulmuş dikmelerdeki yarıklara veya dayanıklı taş duvarlar içine açılmış özel yuvalara sokulurken, Klazomenai işliğinde ahşap dikme kullanıldığı anlaşılmaktadır.

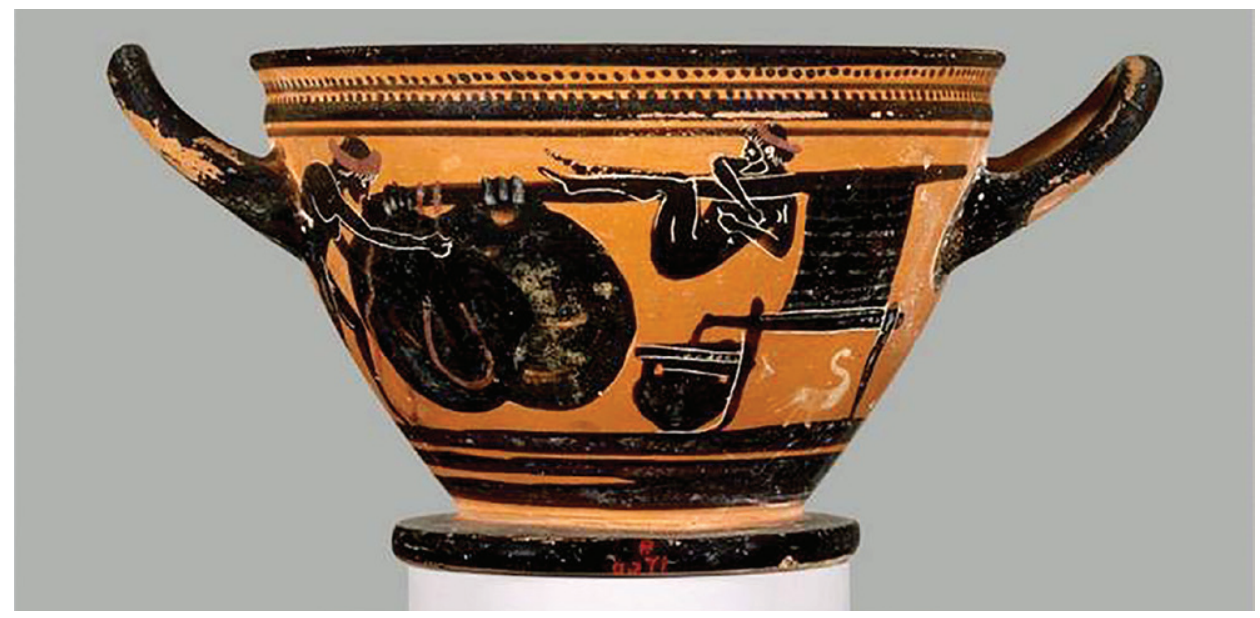

İçki Kabı (Skyphos). M.Ö.VI. Yüzyıl

Üzerinde Klazomenai işliği 1.evresi tarzında çalışan bir iş̧lik betimlenmiştir.

Boston, Museum Of Art

Boston, Güzel Sanatlar Müzesindeki, M.Ö. VI. yüzyılın sonlarına tarihlenen, Attika'da üretilmiş bir içki kabı üzerindeki sahnede, konu olarak zeytinyağı üretimi seçilmiştir. Buradaki oluklu baskı tezgahı, masaya benzer dört ayaklı bir tabla şeklindedir. Masa şekilli bu tezgahın altının boş olduğu, ayaklar arasındaki kaz figürüyle vurgulanmıştır. Boston vazosuyla, Klazomenai işliğinin birbirlerine yakın tarihleri göz önünde tutulduğunda, işliğinin 1. evresi için de bu vazo üzerinde görülen masa şekilli baskı tezgahının bir benzeri düşünülmelidir.
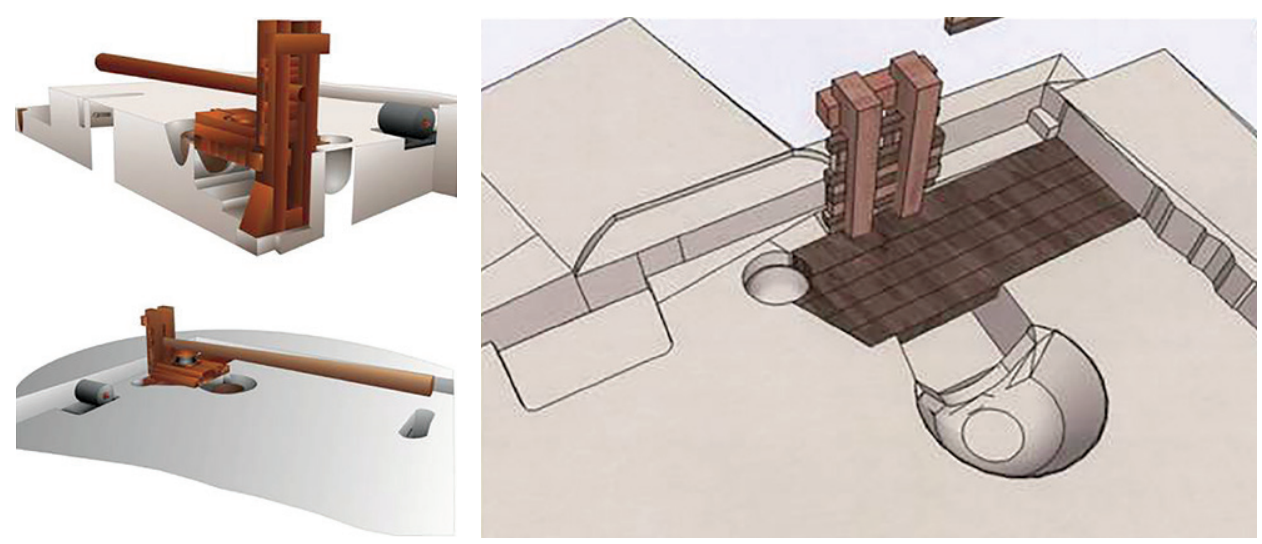
Değirmende ezilip hamur kıvamına getirilen zeytin, hamurunun doldurulduğu keçi kılından yapılmış yuvarlak ve yassı torbaların baskı tezgahında üst üste dizilip, bunların üzerine baskı kolu aracılığıyla basınç uygulanması sonucunda açığa çıkan yağ ve su karışımın ayrıştırılması işlemi, bu sisteme en yakın eleman olan 4 numaralı çukurda gerçekleştirilmiş olmalıdır. Çevresine göre yetmiş santimetre kadar derin olan bu çukura yerleştirilmiş bir kabın [günümüzde üreticiler arasındaki adı polima] içine baskı tezgahından gelen oluk şeklindeki bir araçla, yağ-su karışımı sıvı akıtılmaktadır. Karışım bu kabın içinde beklerken, zeytinyağı ve kara su olarak birbirinden ayrılmaktadır. Boston vazosu üzerinde tasvir edilen baskı düzeneğinde, tezgah tablası üzerinde toplanan yağsu karışımı sıvı bir oluk aracılığıyla krater adı verilen büyük bir kap içine akıtılmaktadır. Buradaki dinlenme sırasında doğası gereği üstte kalan yağ, kepçelerle veya benzeri gereçlerle başka kaplara aktarılmaktadır.
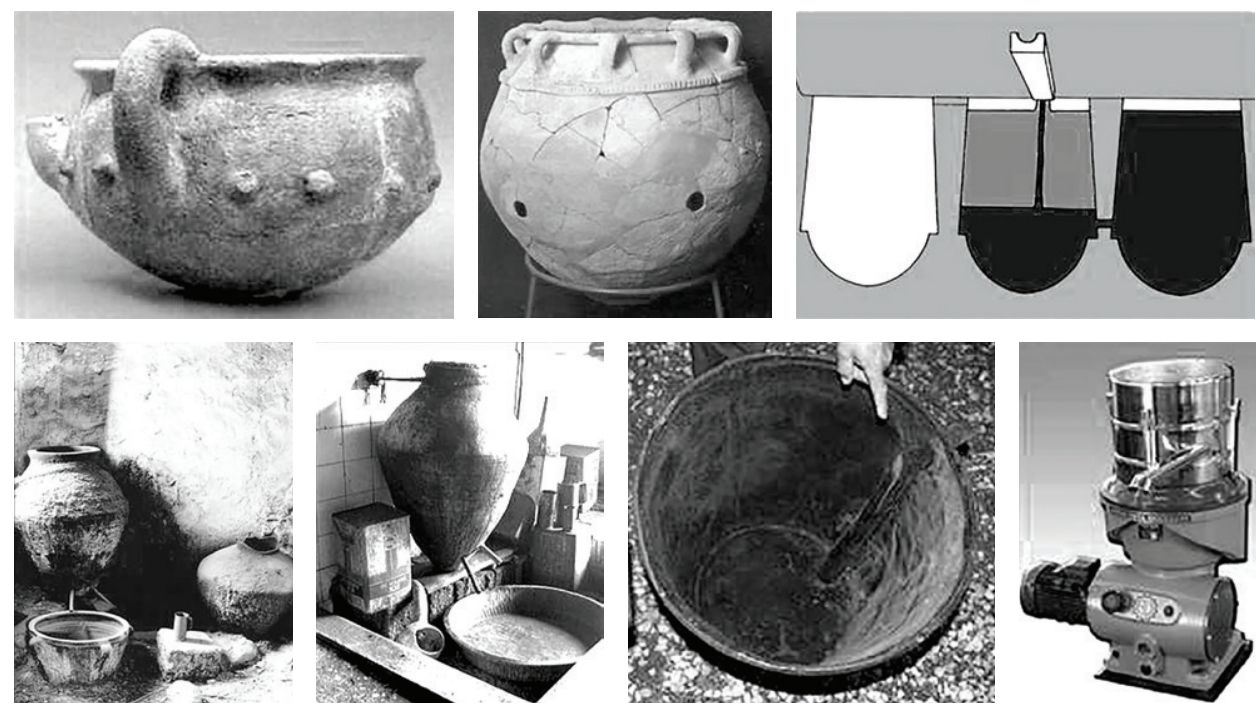

Tarih Öncesi Dönemden Günümüze Kadar Zeytinyağı Separatörleri

$\mathrm{Bu}$ işlemlerin ardından, yağın içinde kısmen kalmış olan suyu ve presleme sırasında kıl torbalardan kaçıp, yağa karışan küçük zeytin parçacıklarından oluşan posayı temizleme işlemi yapılmış olmalıdır. Bugünkü işliklerde de hala kullanılan ve süzgü adıyla tanınan basit bir düzeneğin kökü, kuşkusuz eski çağlara gitmektedir. Bu kap, dibine yakın bölümünde, birbirinden farklı seviyelerde iki akıtıcısı olan bir kaptır. Temizlenmesi istenen yağ, üzerine sıcak su eklenerek bu kabın içinde bekletilir ve bir süre sonra alttaki musluk açllarak dibe çökmüş olan su ve tortu temiz yağ gelinceye kadar akıtılır. Bugünkü zeytinyağı işliklerinde halen kullanılan basit zeytinyağı süzgüleri metalden yapılmışlardır. Ancak, Zeytineli ve Sarpıncık köylerinde, terk edilmiş iki işlikte topraktan yapılmış 
birer yağ süzgüsü görülmektedir. Suyun ve posanın akıtılması işleminden sonra süzgü kabının içinde temizlenmiş olarak kalan yağ, esas depolanacağı küp gibi büyük kaplara boşaltılmaktadır. Klazomenai zeytinyağı işliğinin kuzey duvarına bitişik deposunda bu pithos'lardan bir tanesi anakayaya oyulmuş bir çukur içine yerleştirilmiş olarak günümüze kadar korunup gelebilmiştir.

\section{Evre}
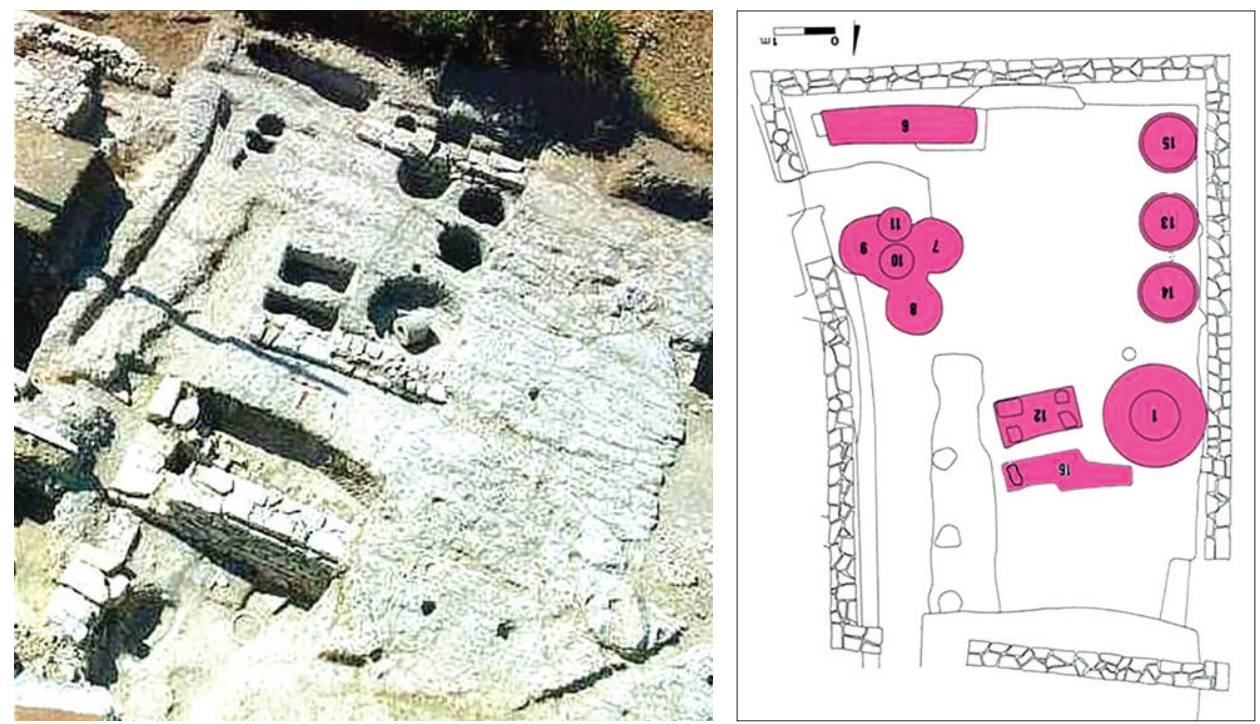

Klazomenai İşliği 2.Evre-Buluntu Durumu ve Planı

M.0̈. 600 yılları dolaylarında kullanılmaya başlanan ve büyük olasılıkla M.0̈. 546'da, Persler'in İonia'yı işgalleri sırasında terk edilen Klazomenai işliğinin, yaklaşık yirmi yıl sonra tekrar çalışır duruma getirildiği anlaşılmaktadır. 2. evrede de işlik olarak aynı mekan kullanılmış, ancak değirmen, pres ve polima'da bir yandan üretim kapasitesini arttırmaya, diğer bir yandan da daha ileri tekniklerin kullanılmasına yönelik yenilikler getirilmiştir.

Rekonstrüksiyonu yapılmış olan 2. kullanım evresinde ana kayaya oyulmuş on iki çukur bulunmaktadır. 


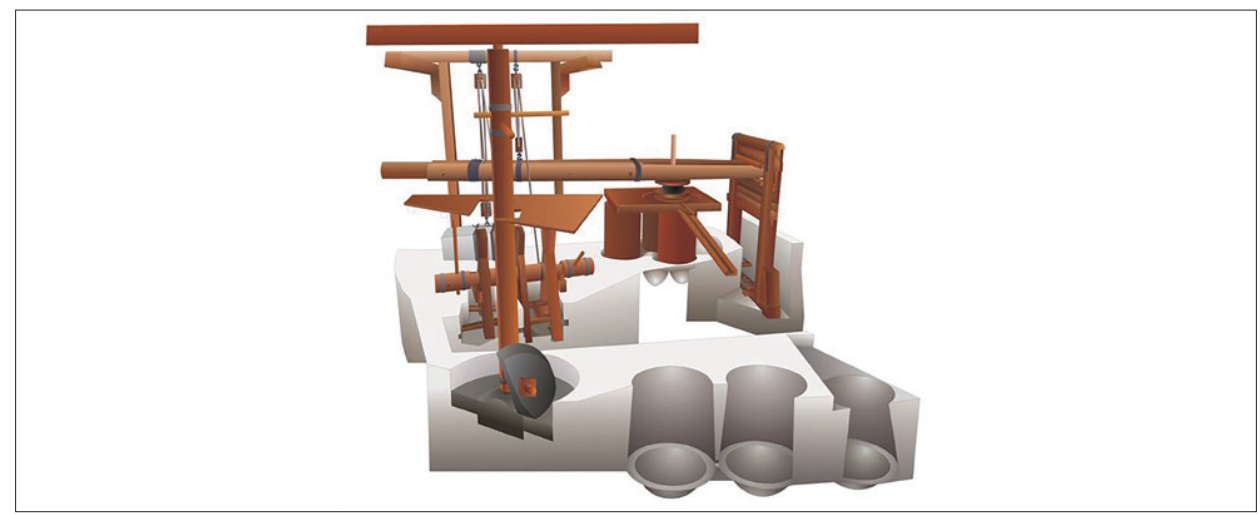

2. Evre
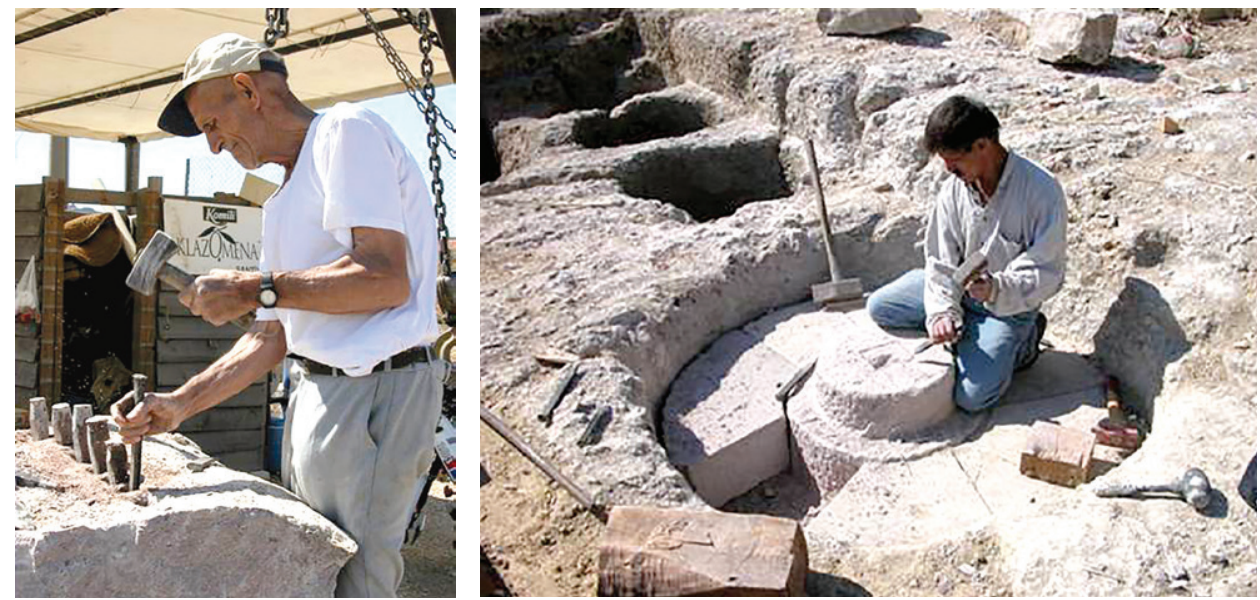

Taş ustası Ömer Engindeniz değirmen taşlarını hazırlıyor.

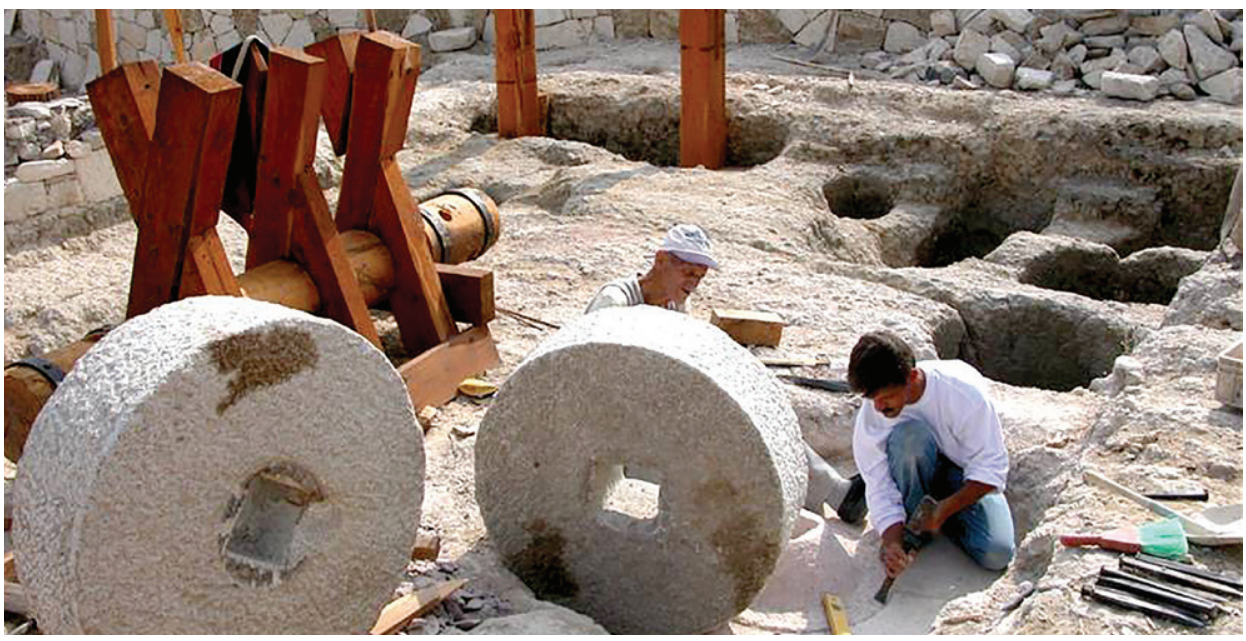

Değirmen yuvası ve taşlar montaja hazırlanıyor. 


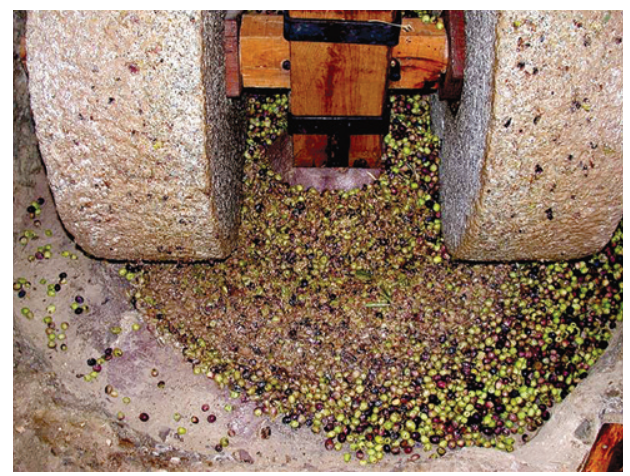

Zeytinlerin Ezilmesi

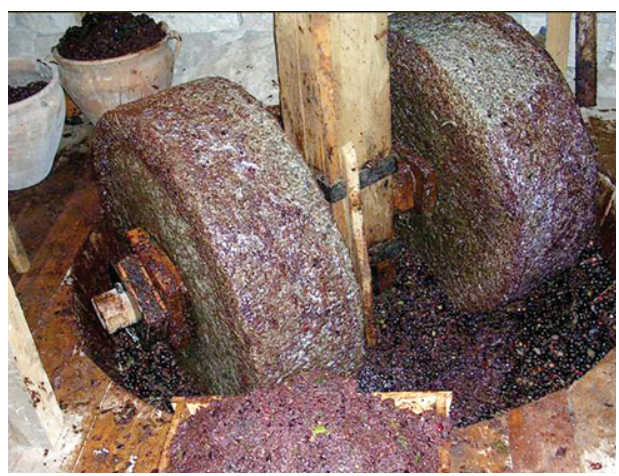

Zeytinlerin Hamur Haline Getirilmesi

Zeytinlerin ezilip hamur haline geldiği daire şeklinde tabanı düz olan çukur, işliğin batı duvarına yaslanmaktadır. Yeniden kurma aşamasında bu çukurun ortasında bulunan daire şeklindeki sığ çukura, ahşap dikey milin dönme sırasında yalpalamaması için merkez taban taşı ve bu taşın çevresinde zeytinleri ezen taşların döndüğü taban taşları yerleştirilmiştir. Dikey milin çevresinde dönen taş/taşlar zeytinyağı teknolojisi için yeniliktir. Zeytin ezme çukurunun çevresinde yeterli yürüme alanı olmadığı için, dikey mil batar kattan çevrilmektedir. Zeytin ezme değirmeninde yapılan denemelerde iki yüz kilogram zeytinin, otuz beş-kırk dakika da hamur haline geldiği gözlenmiştir.

Zeytin kırma değirmeninin yapısı, zeytinyağı teknolojisinin Eski Çağ'daki gelişimi içinde bir yeniliktir. Bir mil etrafında dönen silindir şekilli taşlardan oluşan zeytin kırma değirmenleri, İsrail ve Kıbrıs'ta geç tarihlerde ortaya çıkmıştır.

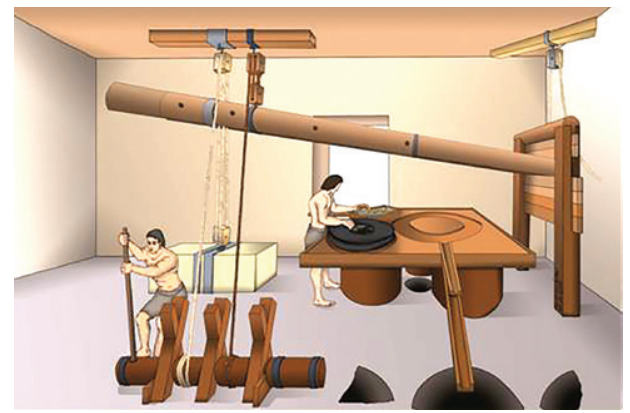

Bocurgat yardımıyla pres kolunun yukarı kaldırılması ve zeytin hamurunun torbalara doldurulması.

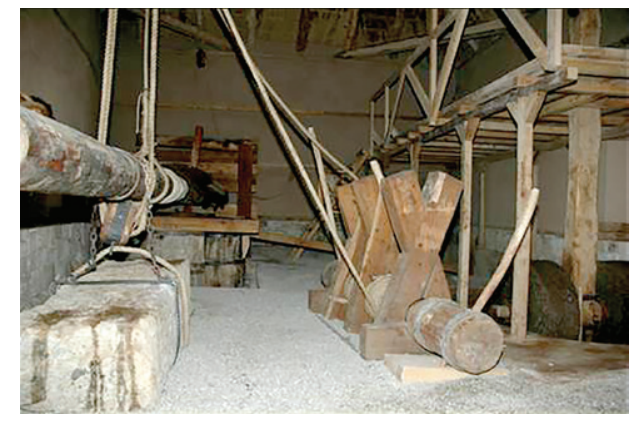

Bocurgat

Baskı kolunun kuzeybatısında dikdörtgen şeklinde, tabanlarında birinin dört diğerinin iki tane ayak izi ve yan yüzeylerinde ayakların yukarıya çıkmaması için kama delikleri olan çukurlara, iki çalışma gözü olan bocurgat yerleştirilmiştir.

Gözlerden birine sarılan halat, makara yardımıyla baskı kolunu yukarıya kaldırılır. 


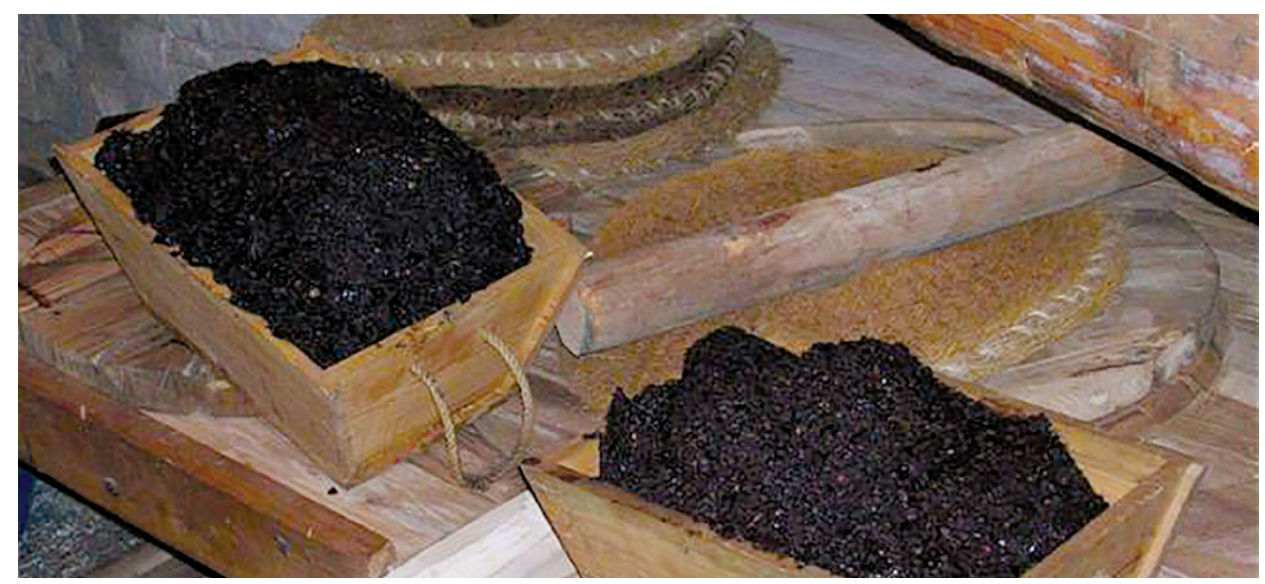

Preslenmek Üzere Hazırlanmış Zeytin Hamuru
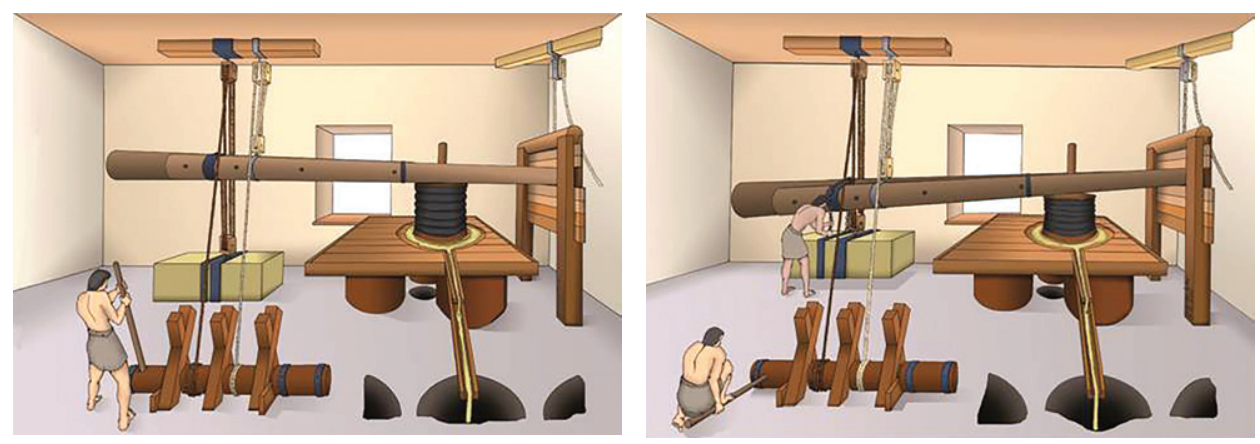

Pres tablasına yerleştirilen torbalar bocurgatın pres kolunu aşağı doğru çekmesiyle sıkıştırılır. Torbalardan çıkan zeytinyağı ve karasu tablanın üzerinde toplanır. Kanal yardımıyla ayrıştırma çukuruna akar.

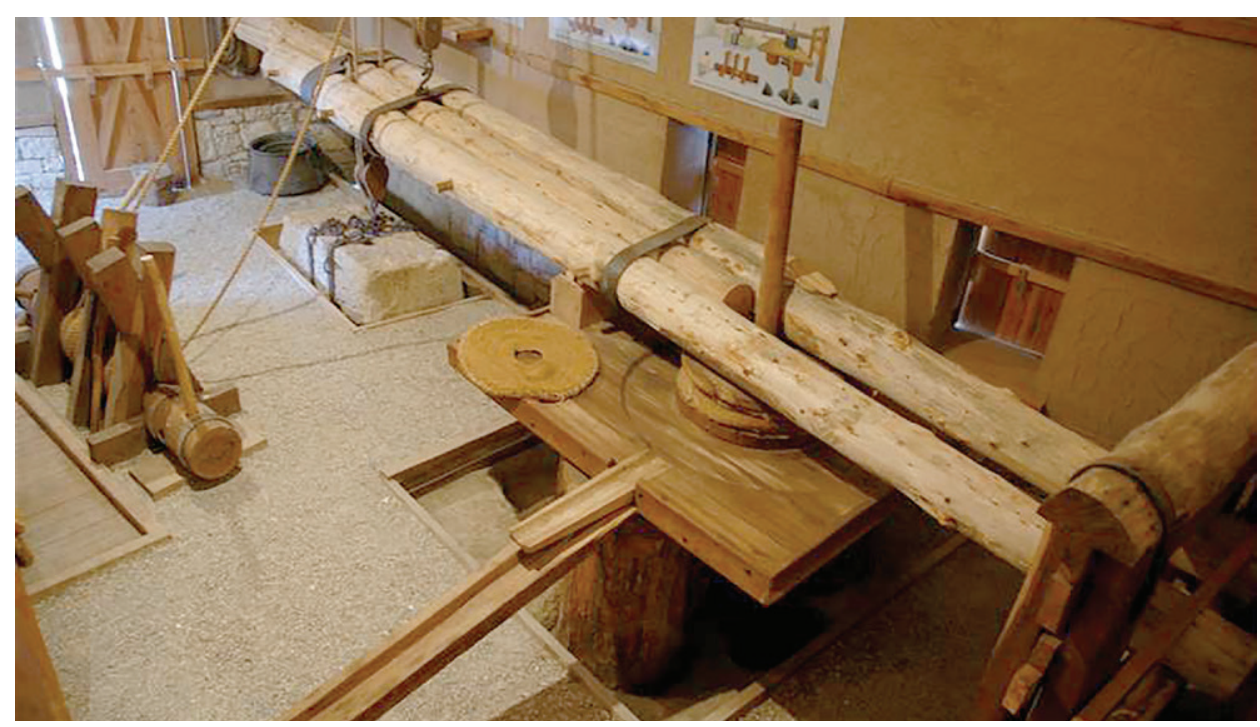

Baskı Sistemi (Bocurgat, pres tablası, pres kolu) 


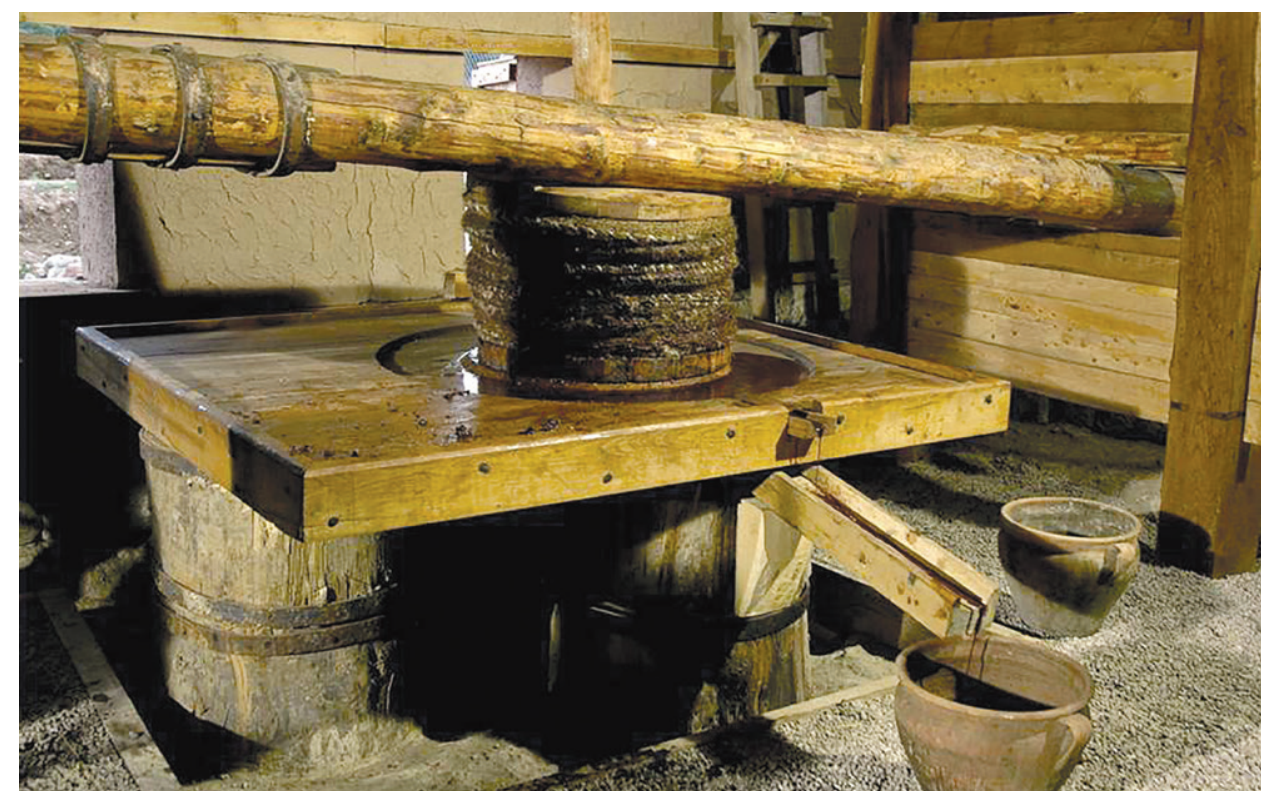

Baskı Kolu Dikmenleri, Baskı Tablası ve Baskı Kolu Rekonstrüksiyonu

2. evre işliğinde bol miktarda elde edilen zeytin hamurunu, bir kerede preslemek için büyük bir baskı sisteminin yapıldığını görüyoruz. Bu sistem işliğin doğu tarafında güney-kuzey doğrultudadır. Baskı kolu ve dikmeleri, baskı tablası ve bocurgattan oluşmaktadır. Baskı kolu dikmeleri, derin dikdörtgen bir çukurun içindedir. Yukarıya doğru çıkmamaları için, kayanın yan yüzeylerine açılmış kama deliklerine ahşaplarla sabitlenmişlerdir. Baskı kolu dikmelerinin kuzeyinde, baskı tablasının ayaklarının oturduğu daire şeklinde üç tane sığ çukur ve bunların ortasında da, tabanı yarım küre şeklinde iki silindir çukur bulunur. Ahşap ayakların üzerine yerleştirilen ahşap baskı tablasının boyutları da zorunlu olarak büyüktür. Ayakların arasında kalan çukurlara baskı tablasından sızan karasu-zeytinyağı toplanmaktadır. Baskı kolu dikmeleri arasının geniş, baskı tablasının büyük olması burada işliğin kuzey duvarına kadar uzanan büyük ve çatal bir baskı kolunun varlığına işaret eder.

Daire şeklindeki çuvalların içine zeytin hamuru, yirmi santimetre kalınlığında doldurulur. Ortalama on üç tane çuval, bir diskin üzerine üst üste yerleştirilir. Disk kaydırılarak, baskı tablasının ortasına yerleştirilir. Üzerine ortası delik bir disk daha yerleştirilip, ortalarına çuvalların kaymaması için kalın bir mil takılır. Bocurgatın diğer gözüne ters sarılan halat, makaralar ve ağırlık yardımıyla baskı kolunu aşağıya doğru çeker. Manivela sistemiyle sıkışan çuvalların içindeki karasu-zeytinyağı çıkarak baskı tablasının üzerine, buradan da ahşap bir kanal yardımıyla polüme [ayrıştırma çukurlarına] akar. 


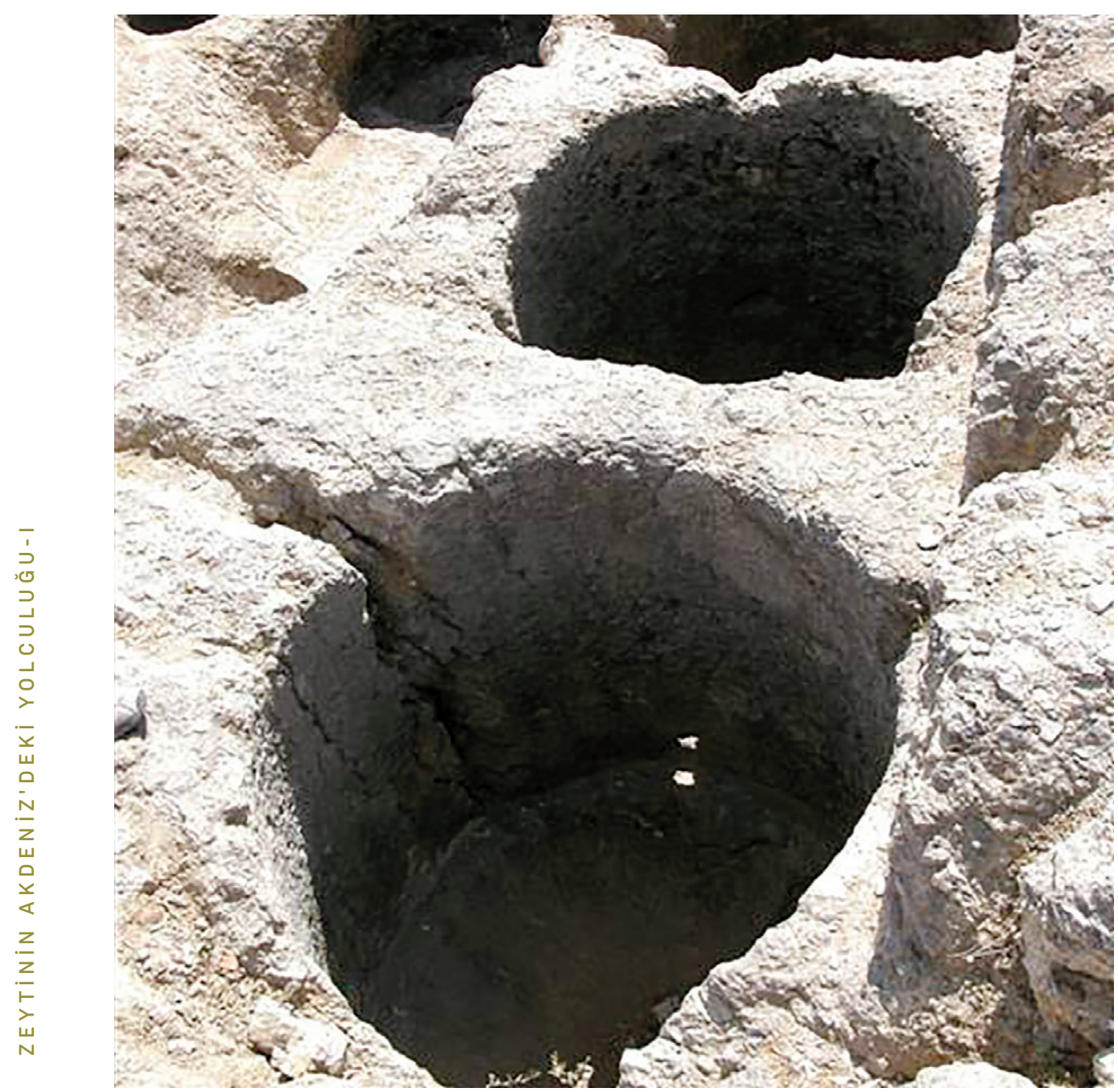

Bileşik Kaplar Prensibine Göre Çalışan Yağ Ayrıştırma Düzeneği

Birinci evrenin yağ ayrıştırma kabının içine yerleştirildiği çukur, doldurulmuş ve yeni yağ ayrıştırma düzeneği için üç kuyu kazılmıştır. Polüm işliğin batı duvarına yaslanmış, silindir biçiminde her biri yedi yüz litre sıvı alabilen üç tane çukurdur. Bunlardan ikisi, bir delikle birbirine bağlanmış ve bileşik kaplar sistemi oluşturulmuştur. 


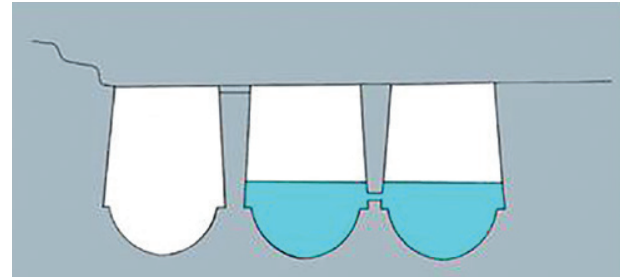

1- Birbirleriyle bağlantılı iki kuyu yarıya kadar su ile doldurulur.

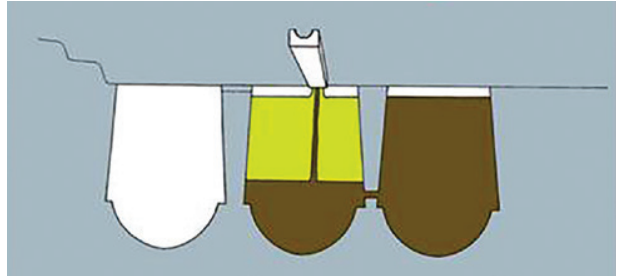

2- Baskıdan gelen karasu-yağ karışımı sıvı ortadaki kuyuya akıtıyor. Hafif olan yağ, ortadaki kuyuda üstte kalıyor. Ağır olan karasu delikten öteki kuyuya geçiyor.

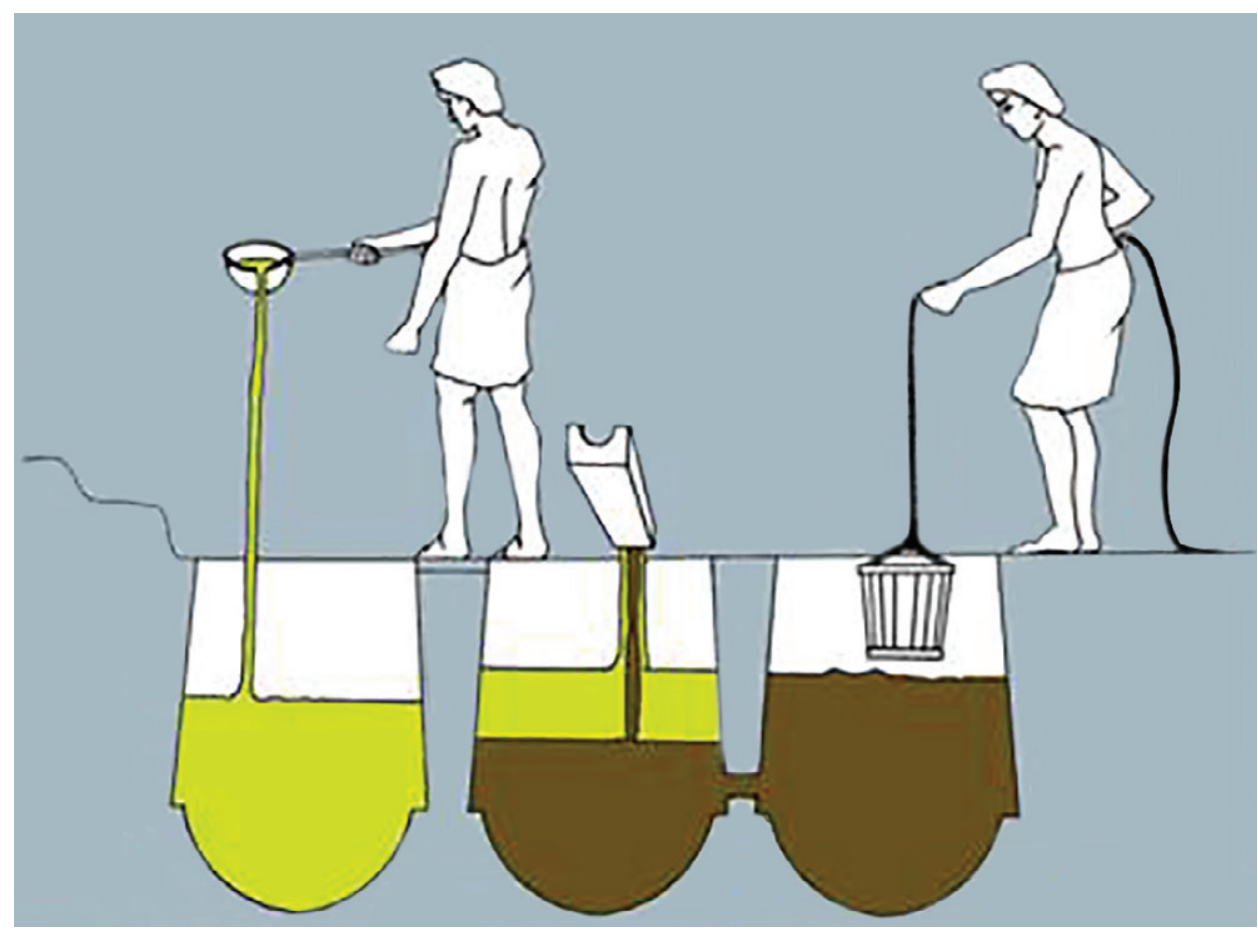

3- Kuyular dolunca, ortadaki kuyuda üstte kalan yağ, yayan kepçe ile dinlenmek üzere üçüncü kuyuya aktarıııyor. Karasu ile dolu birinci kuyu da boşaltılıyor.

Bu iki kap, sıkım başlamadan önce yarıya kadar suyla doldurulur. Zeytin sıkımı başlayınca, baskı tablasından ahşap kanal yardımıyla ortadaki çukura karasu-zeytinyağı akar. Bu karışım, sudan hafif olduğu için suyun üstünde kalır. Bir süre sonra karasu, zeytinyağından ayrışarak dibe doğru çöker ve zeytinyağı üstte kalır. Her iki çukurda sıvı seviyesi eşit olacağından, alttaki delikten su-karasu karışımı ikinci kuyuya geçer. Burada kesintisiz bir ayrıştırma olmaktadır. Ortadaki kuyuda biriken zeytinyağı bir süre sonra, bir kap yardımıyla üçüncü kuyuya alınarak dinlendirilir. Bu ayrıştırma sistemi dönemi için önemli bir yeniliktir. 
İsrail ve Kıbrıs'ta yapılan kazılarda ve araştırmalarda, belirlenen Eski Çağ'a ait ve Klazomenai işliğiyle, çağdaş zeytinyağı üretim işliklerinde üç gözlü polima'ya rastlanmamaktadır. Oralardaki işliklerde presten gelen sıvı, pres tablasının altında yer alan basit ve tek gözden oluşan bir kuyuda veya toprak bir kap içinde bekletilerek ayrıştırılmakta ve bu kuyu veya kap doldukça, yağın alınması ve alt kesimde biriken karasuyla tortunun boşaltılması için işleme ara vermek zorunluluğu ortaya çıkmaktadır.

Klazomenai işliğindeki üç gözlü yeni yağ ayrıştırma düzeneğiyle, sürekli çalışma olanağı yaratılmıştır. Bu özellik, İonia'da doğanın yoğun gözlenmesi sonucu elde edilen bilgi birikimi ve hidrolik biliminin ulaştığı düzeyi de yansıtmaktadır. Daha eski bir örneğine rastlamadığımız, bileşik kaplar esasına göre düzenlenmiş üç gözlü polima'nın ilk olarak M.ö. VI. yüzyılda Klazomenai'deki bir işlikte karşımıza çıkması da, o tarihlerdeki teorik bilgi birikiminin uygulama alanına sokulmuş olmasıyla açıklanabilir.

M.Ö. VI. yüzyılda Klazomenai işliğinde, dikey bir mil çevresinde dönen taşlarla bol miktarda zeytin hamuru elde edilmiştir. Bu zeytin hamurları büyük baskı tablası ve baskı koluna gereksinim duyulmasını sağlamış, büyük baskı kolu da bocurgatı zorunlu hale getirmiştir. Bol miktarda çıkan karasu-zeytinyağı, sürekli ayrıştıran polümün ortaya çıkmasını sağlamıştır.

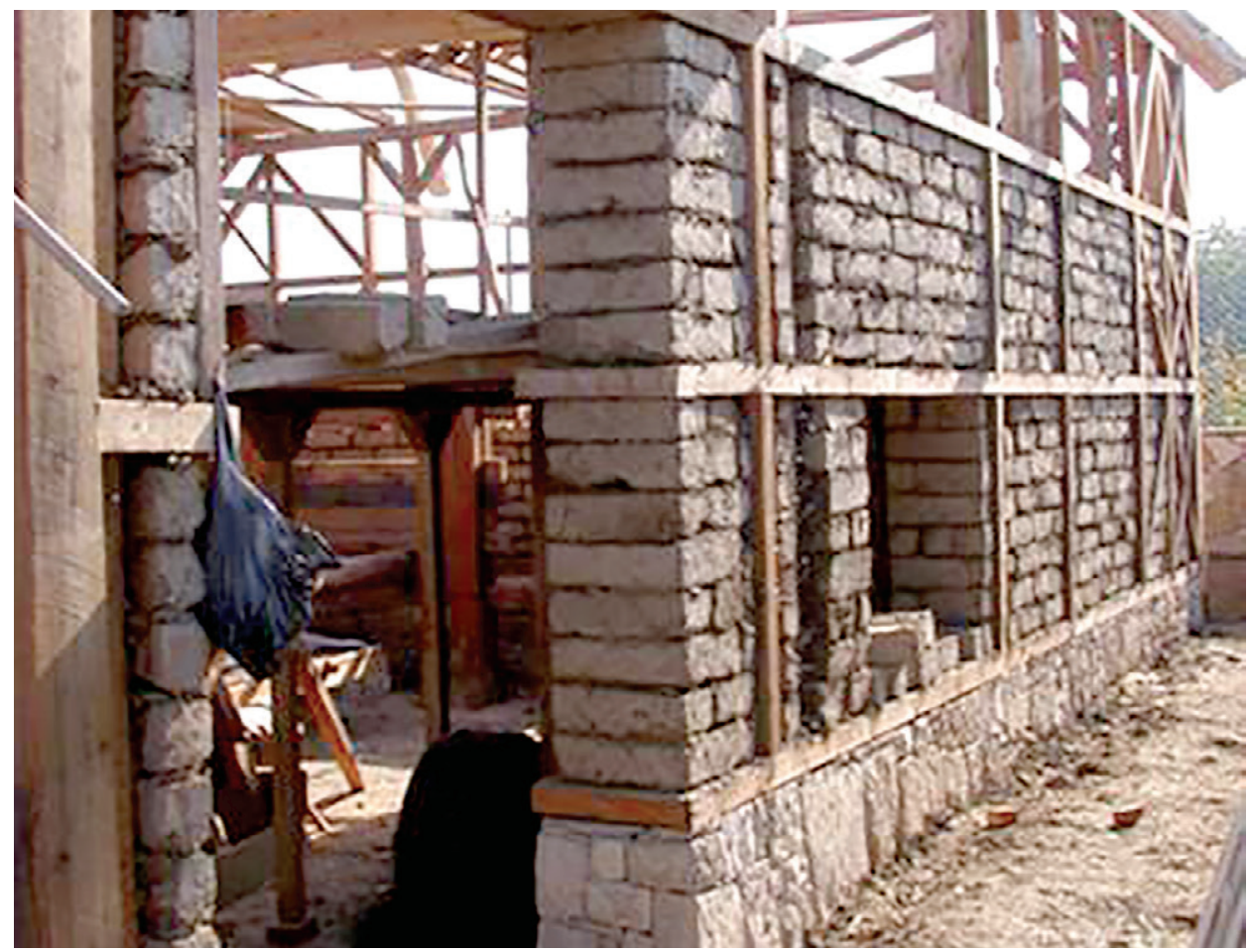

Klazomenai Zeytinyağı İşliğinin Ahşap Karkasla Desteklenen Kerpiç Duvarları 
Rekonstrüksiyon çalışmasında, deneysel arkeoloji dikkate alınarak duvar ve çatılar döneminin yapı tekniğine göre inşa edilmiştir. Duvarlar, taş subasman ve ahşap karkasla desteklenmiş kerpiçtir.

İşliğin çatısı, Klazomenai'de bulunup M.Ö. geç VII. yüzyıla tarihlenen ve kapağı saz çatılı bir eve benzetilen pişmiş topraktan lahdin şekline uygun olarak yapılmıştır.
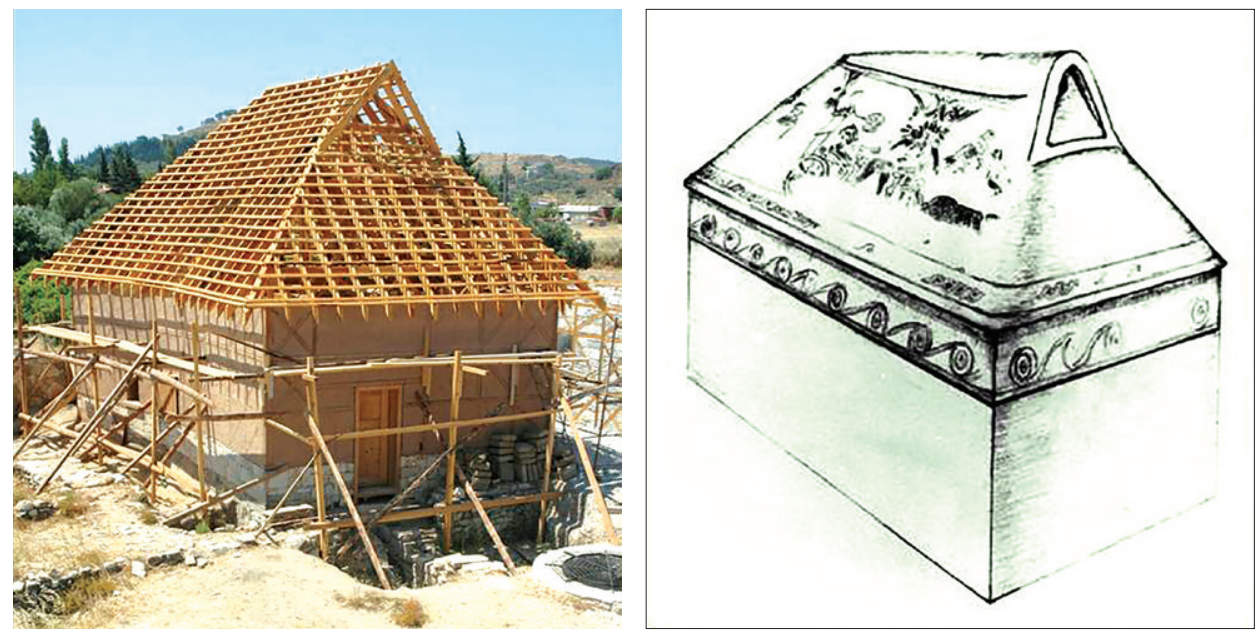

Çatı Kurgusu İçin Örnek Alınan, M.Ö. VII Yüzyılın Son Çeyreğine Tarihlenen Bir Klazomenia Lahiti ve İşliğin Çatısı
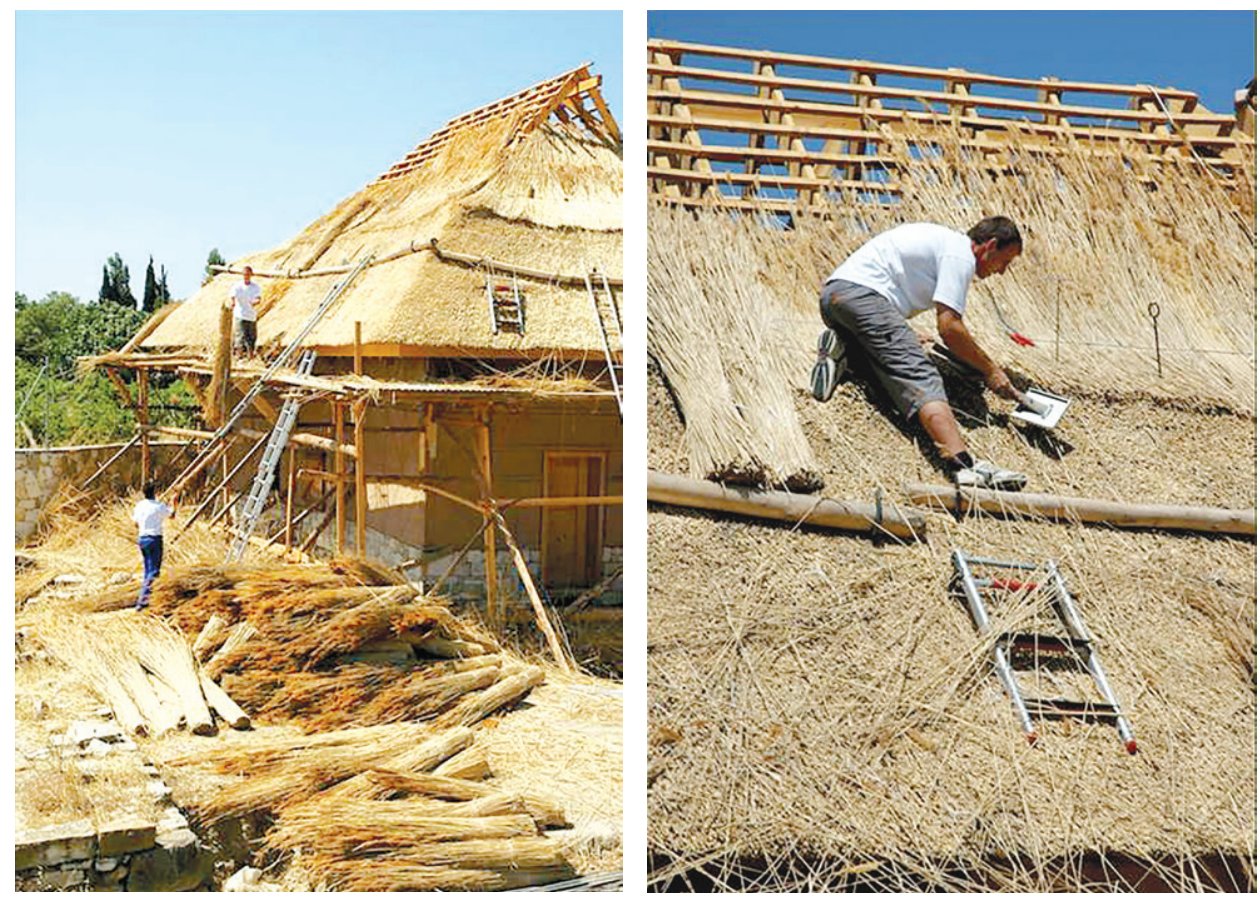

Baba oğul Barfuss ustalar çatıyı kamıș ile örüyorlar. 


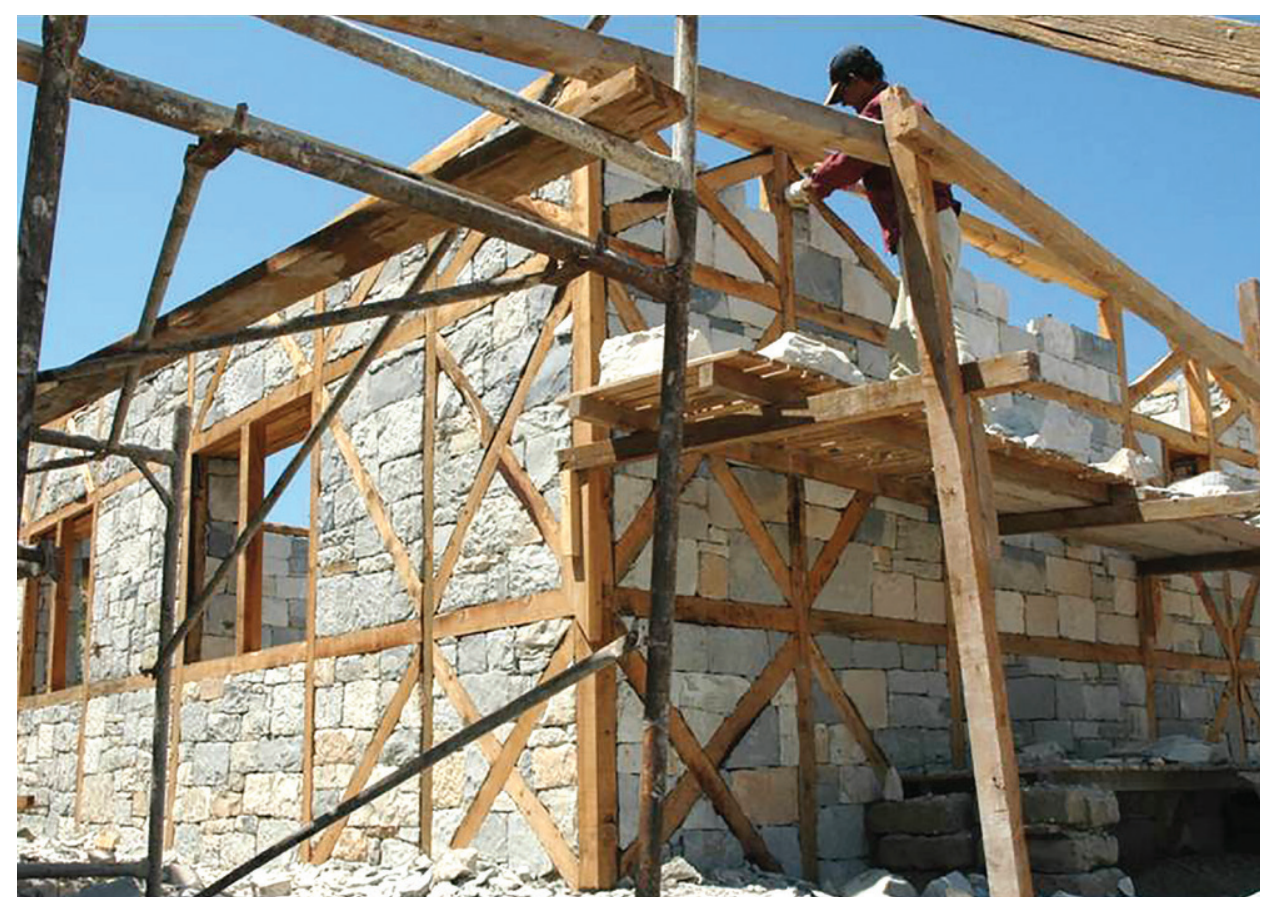

Ahşap karkaslı taş depo binasında restarasyon çalışmaları.

Ancak, M.Ö. VI. yüzyılın ilk yıllarına tarihlenen, ev şeklindeki bir pişmiş toprak lahitin sazdan yapılmış kırma çatıyı taklit eden kapağına göre, o yıllarda yapılarda düz toprak damların yanı sıra saz örtülü kırma çatılar da kullanılmaktaydı. Depodaysa, düz toprak çatı uygulanmıştır.

\section{Depolar}

Birinci kullanım evresi deposu, işliğin kuzeyinde yer almaktadır. Deponun zeminine ağzı zemin seviyesinde küçük bir küp gömülmüş ve çevresi yassı taşlarıyla döşenmiştir. Bunun dışında, aynı alanda üç tane daha küp yuvası vardır.

İkinci evre deposu, işliğin batısında bulunur. Burada, kayaya oyulmuş merdivenlerden bodrum katına inilmektedir. Zemin ve bodrum katı döşeme tahtalarıyla birbirinden ayrılmıştır. İşlikte elde edilen zeytinyağı, büyük bir olasılıkla burada küpler ve amphoralar içinde saklanmaktaydı. Ağız ve gövdesinde boya bandlar taşıyan ve literatürde Klazomenai amphorası olarak adlandırılan çift kulplu vazolar denizaşırı topraklarda, örneğin Karadeniz'deki Ion kolonilerinde, Kuzey Afrika'da Nil deltasında ve Batı Akdeniz İberik Yarımadası'na kadar uzanan çok geniş bir coğrafyada rastlanmıştır. Büyük bir olasılıkla bu tür amphoraların içinde taşınan Klazomenai zeytinyağları, Antik Dönem'de kent için önemli bir ticari kaynak durumundaydı. 


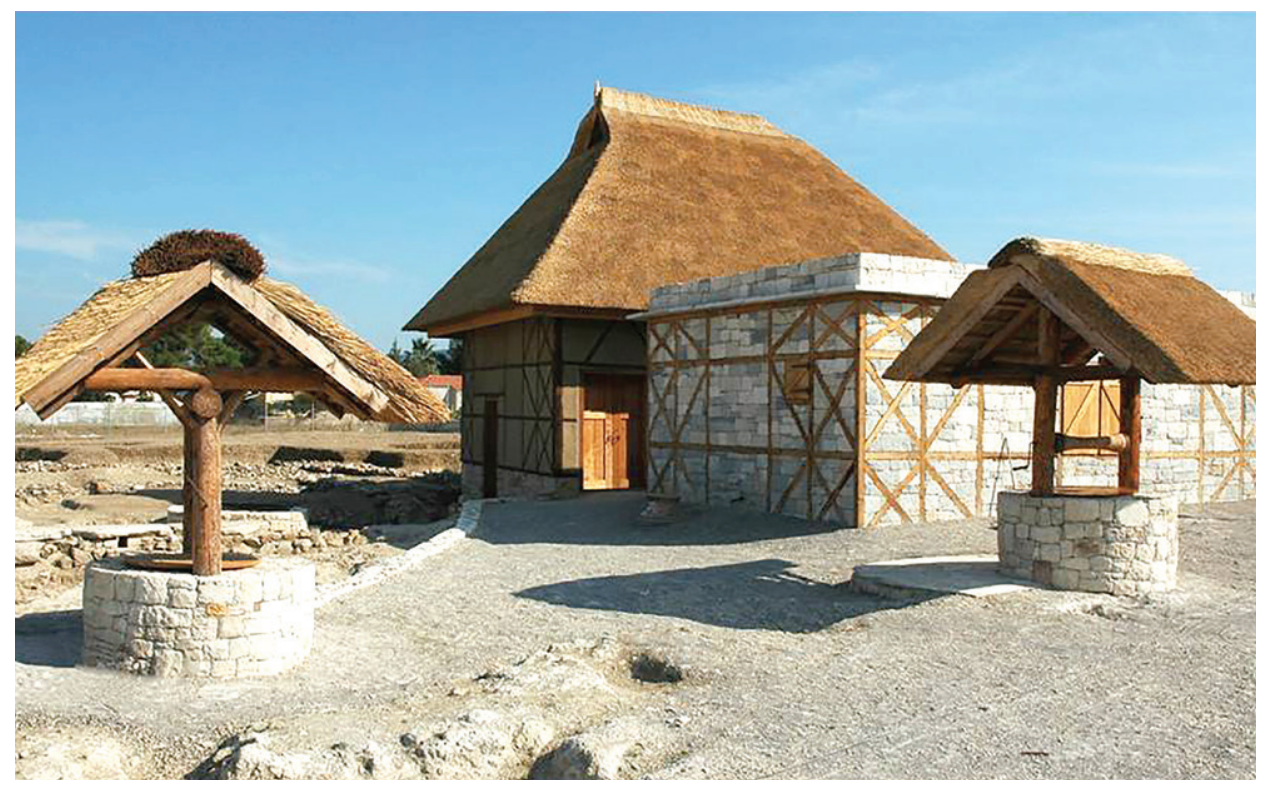

Klazomenai Antik Zeytinyağı İşliği Restorasyondan Sonra

\section{EVRE DEPOSU}

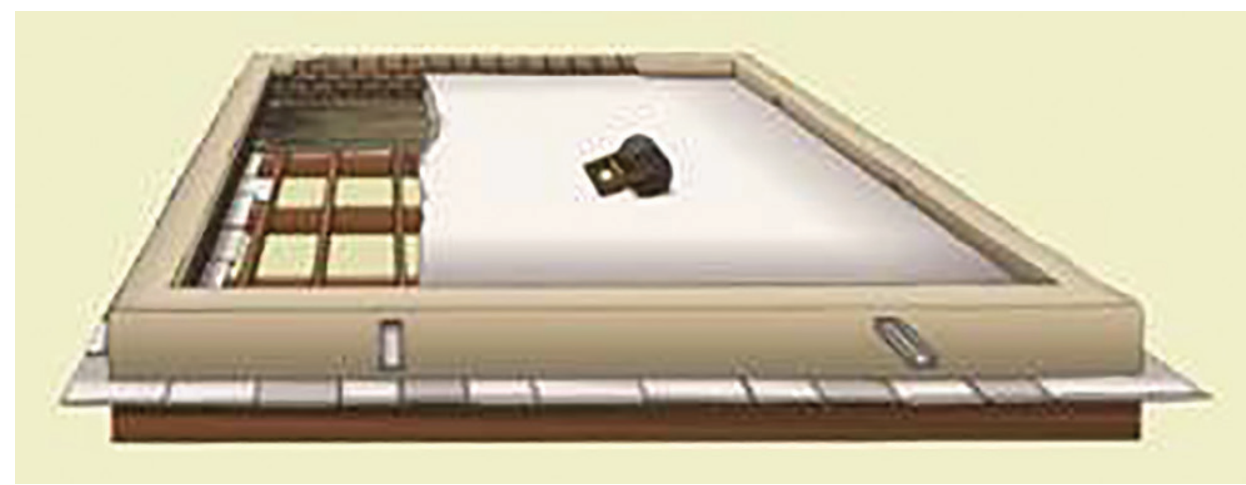

Sıkıştırılmış Toprak Çatı

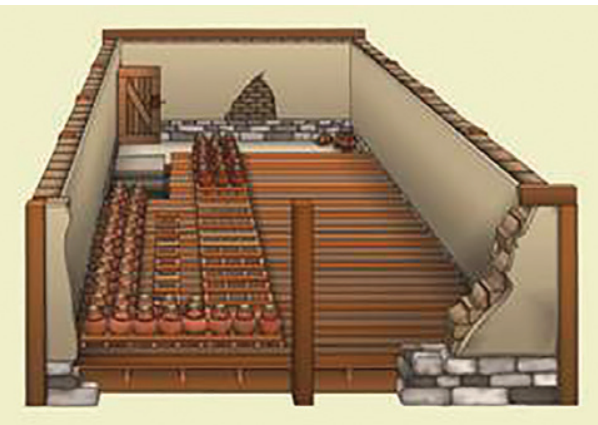

Zemin Kat

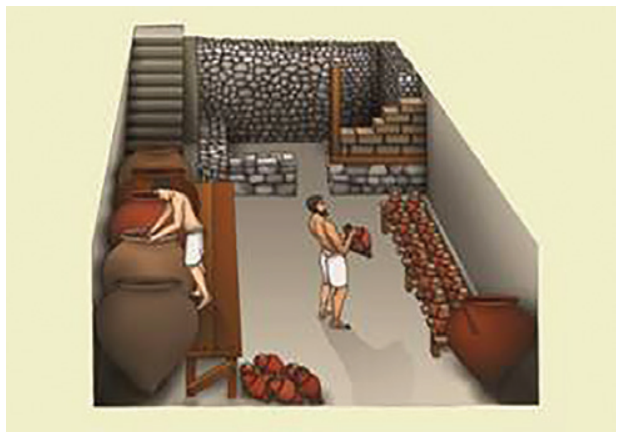

Bodrum 

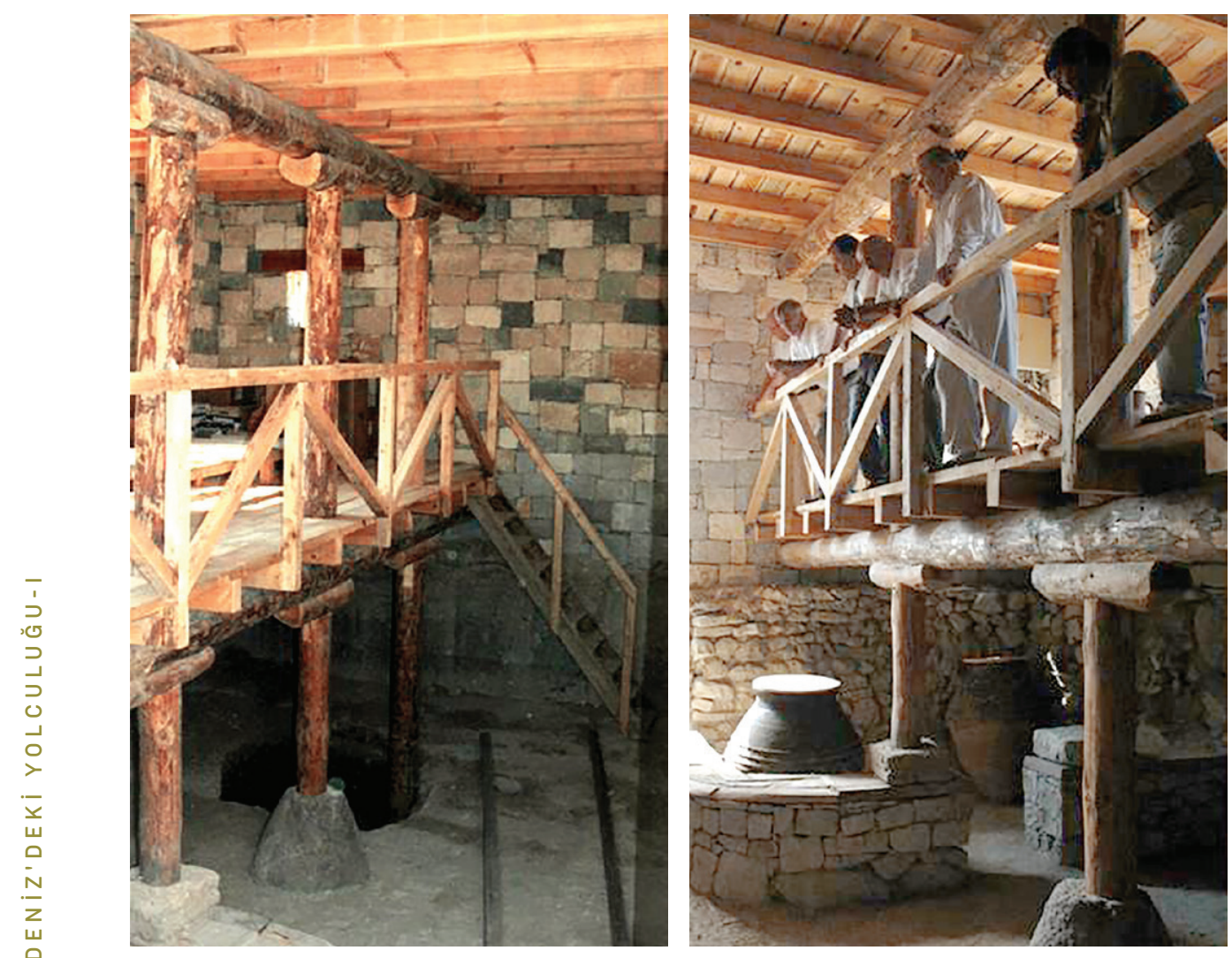

Klazomenai İşliğinin Bodrum ve Zemin Kattan Oluşan İki Katlı Deposu

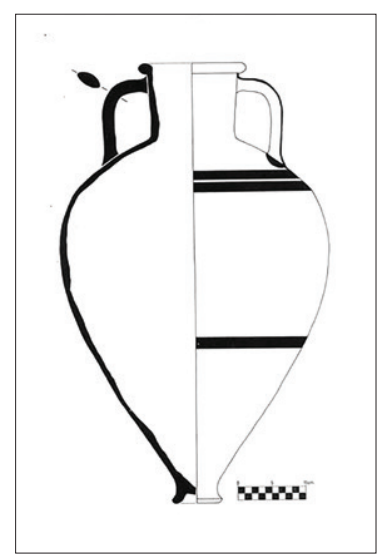

Zeytinyağı ve Șarap Tașıma ve Depolama İçin Klazomenai'de

Klazomenai Amphoraları Üzerindeki Üretici veya Satıcı Firma Markaları Üretilmiş Amphoralar

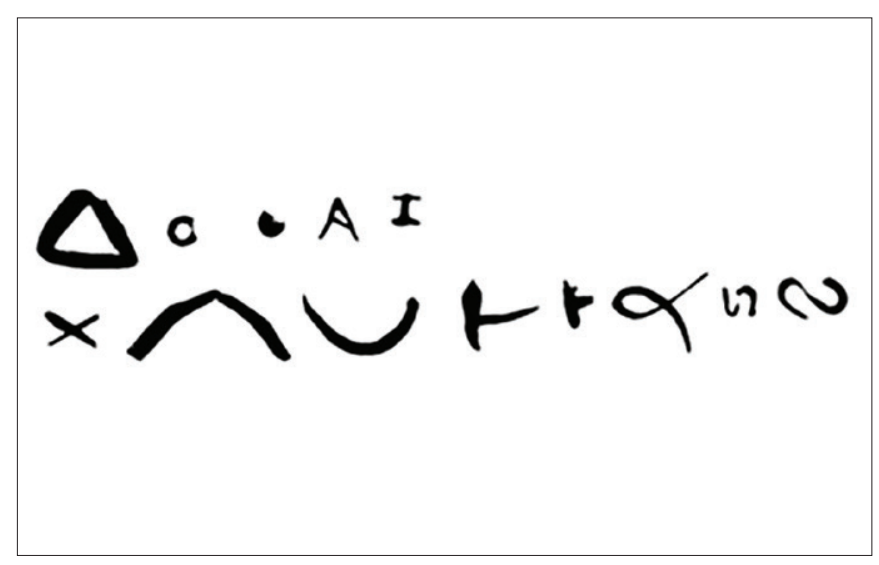




\section{Klazomenai İşliğinin, Zeytinyağı Teknolojisine Katkıları}

Klazomenai zeytinyağı işliğinde, M.Ö. VI. yüzyılda karşılaşılan yenilikler, tarihin akışı içinde Doğu Akdeniz havzasından Batı Akdeniz havzasına doğru dağılan yabani zeytin ağacının islah edilip kültür bitkisine dönüştürülmesinde ve meyvelerinden yağ elde edilmesinde, İonia'nın hiç değilse teknolojik açıdan büyük katkılarının olduğunu göstermektedir. Bu katkılar şu şekilde sıralanabilir:

1- Bileşik kaplar esasına göre çalışan ve kesintisiz üretim sağlayan üç gözlü yağ ayrıştırma düzeneği [polima],

2- Zeytin kırma değirmeninin, sert taştan yontulmuş ve bir mil etrafında dönen ağır silindirlerden oluşturulması,

3- Büyük kapasiteli üretimi sağlamak için büyük pres ve bunun zorunlu bir sonucu olarak baskı sırasında bocurgat kullanılması.

Zeytinyağı teknolojisinin gelişim süreci içinde, M.ö. VI. yüzyılda Klazomenai işliğinde ilk defa uygulanmaya başlanan bu buluşlar, yapılan işin doğasının rasyonel bir şekilde gözlemlenmesi ve bu gözlem sonuçlarının hidrolik, mekanik alanlarında elde edilmiş olan bilgilerle bütünleştirilmesinden sonra ulaşılan teknolojik yeniliklerdir. Günümüzde bazı işliklerde hala kullanılmakta olan teknolojinin temelini oluşturmaktadırlar.

\section{Klazomenai ve Zeytinyağı}

Klazomenai'de, Hamdi Balaban'ın tarlasında açığa çıkarılan ve geliştirilmiş 2. evresi M.ö. VI. yüzyıl ikinci yarısına tarihlenen zeytinyağı işliğinden başka, yine aynı döneme tarihlenen iki işlik daha belirlenmiştir. İleride yapılacak araştırmalarla, bu sayı artacak gibi görünmektedir. Bu üç işlik, Klazomenai'nin M.Ö. VI. yüzyılın ikinci yarısında zeytinyağı üretiminde büyük bir atılım yaptığını göstermektedir. İşliğin küçük kapasiteli l. evresinde üretim, kentin ve yakın çevresinin gereksinimi karşılamaya yönelikken, 2. evresinde dış satış önem kazanmış gibi görülmektedir. Klazomenaililer sıvı ürünler için kendilerine özgü depo kabı olan kuşak bezemeli amphoralar üretmişler ve bunları şarapla, zeytinyağının depolanmasında ve taşınmasında kullanmışlardır. Klazomenai'de kazı sonucu açığa çıkan amphoraların bir çoğunun boyun veya omuzlarında zeytinyağı üretimini yapan kişiyi/firmayı ya da ihracatı yapan kişiyi/firmayı tanıtan harfler, semboller bulunmaktadır.

Bu tür ambalaj kaplarının, M.Ö. VI. yüzyılın ikinci yarısında hem üretildiği merkez olan Klazomenai'de hem de deniz aşırı ülkelerde çok sayıda ele geçmesi, dış ticarete yönelik bu atılımın bir kanıtıdır. Klazomenai, diğer İon kentleriyle birlikte Mısır, Nil deltasında 
Naukratis adlı bir ticaret merkezinin kuruluşuna, ayrıca Miletos'la birlikte Karadeniz'in tüm sahillerine yayılan İon kolonilerinin kuruluşlarına katılmıştır. Klazomenai işliklerindeki sürekli üretime yönelik teknolojik yenileştirme girişimlerine ve Klazomenaililerin ilişki içinde oldukları merkezlerde bol sayıda ele geçen Klazomenai'ye özgü depo amphoralarına bakıldığında, Klazomenai'nin M.Ö. VI. yüzyılın ikinci yarısında zeytinyağı üretiminde ve ihracatında o günkü dünya içinde önemli bir konuma ulaştığı anlaşılmaktadır.

Klazomenai işliğinin, zeytinyağı teknolojisinin gelişmesine katkıları önemlidir. M.Ö. VI. yüzyılda bu işlikte ortaya çıkan yenilikler, neredeyse günümüze kadar değişmeden Anadolu topraklarında kullanılmıştır. Tarihin akışı içinde ilk defa bu işlikte karşılaştığımız, zeytinyağı elde etme teknolojisinde yeni bir dönem açan yenilikler, Batı Anadolu uygarlığına özgü olmalıdır. İon uygarlığını oluşturan bu unsurların arkasında inançlı ancak laik, akılcı, isonomia [eşit paylaşma] ilkesini benimsemiş, girişimci, kader kavramını tanımayan, meraklı ancak merakta ölçüyü kaçırmayan, her durumda çözüm arayan, doğanın kanunlarını belirlemeye çalışan, onları günlük yaşama uygulayan, sentezci bir insan tipi belirginleşmektedir. İşte bu insan, Batı Anadolu'nun insanıdır. 



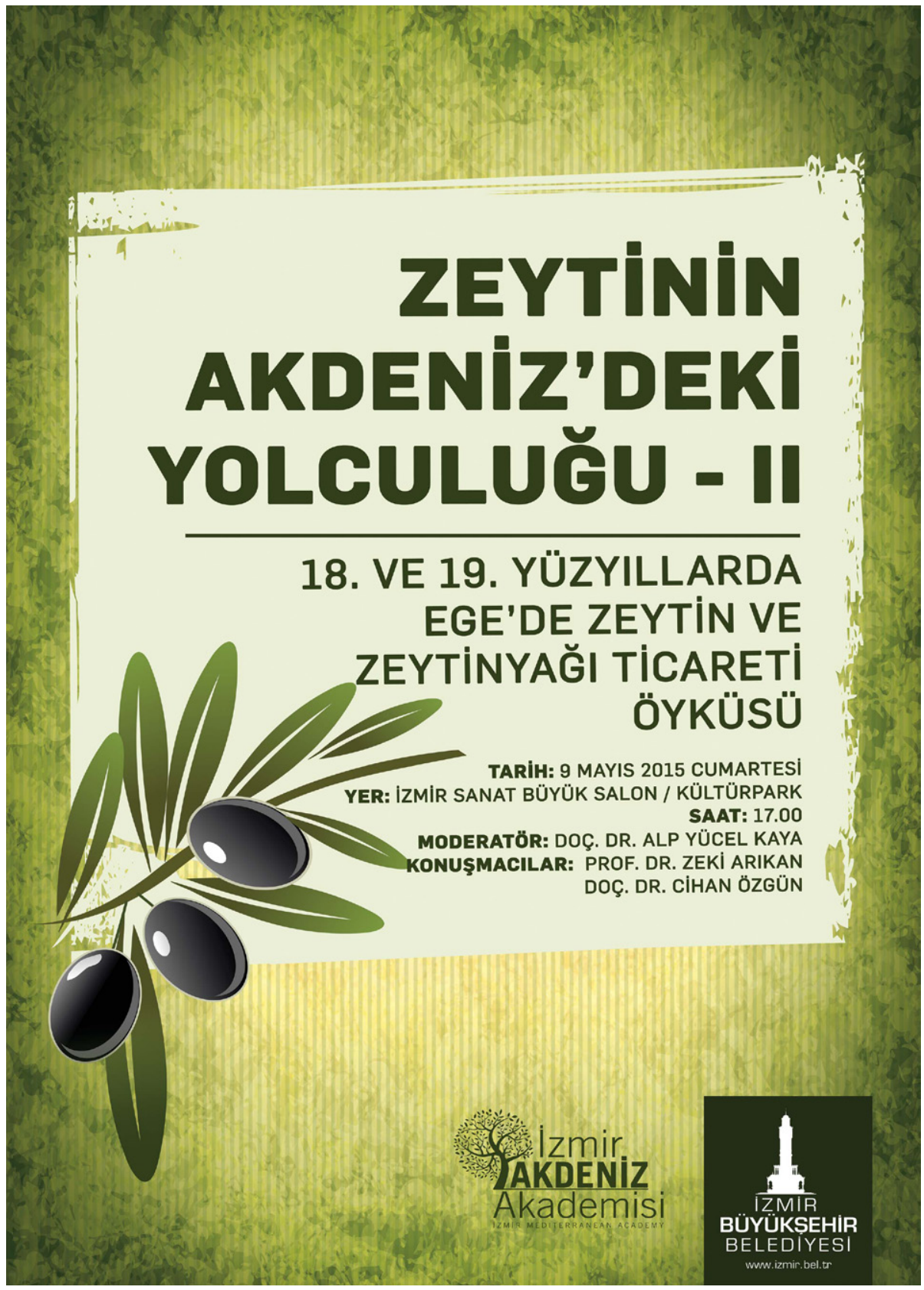




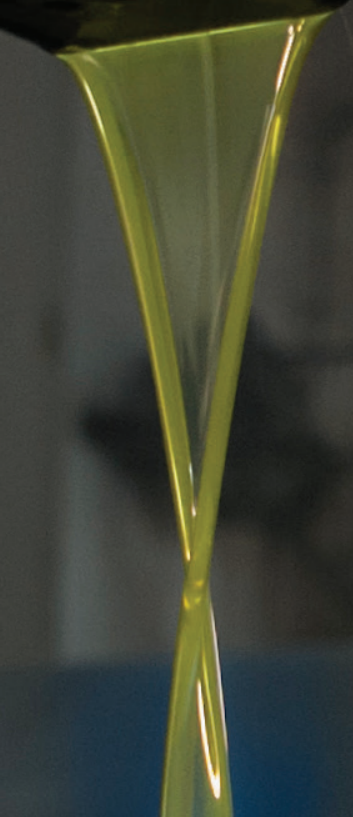

Fotoğraf: TOLGA ÖZMEN 


\section{İstanbul'a Zeytinyağı Gönderilmesi}

\section{Prof. Dr. Zeki ARIKAN}

Ege Üniversitesi Emekli Öğretim Üyesi

Prof. Dr. Robert Mantran'ın deyimiyle, bir mide kent [capitale ventre] olan İstanbul'un beslenmesi önemli bir sorundu ve doğrudan doğruya devleti ilgilendiriyordu. Çok kalabalık bir nüfusu barındıran [XVII. yüzyılda, 700.000] İstanbul'un beslenmesi, öncelikli sorunlardan biriydi. İstanbul'a gönderilen ürünler arasında, zeytinyağı da vardı. Osmanlı İmparatorluğu, zeytinyağı üretim ve tüketiminde tarihin deriliklerine giden bir mirası devralmış ve sürdürmüştür. Osmanlı egemenliğinde bulunan Kuzey Afrika, Doğu Akdeniz, Batı Anadolu ve adalarda zengin bir zeytincilik kültürü vardı. Adalar ve Ege Bölgesi'nde üretilen zeytinyağının büyük ölçüde İstanbul'a gönderilmesi, başkentin gereksiniminin karşılanmasına yönelik bir önlem olarak görülmektedir. Adalar içinde, Midilli ve Anadolu'da Ayvalık bu bağlamda önemli merkezlerdi.

Zeytin, Akdeniz ülkelerinin kıyı şeridinde yetişen en eski ürünlerden biridir. Fernand Braudel, zeytinin Akdeniz havzasında yaygınlaşmasını, bitkilerin yer değiştirmesiyle açıklar. Ona göre zeytin, Mezopotamya'dan Akdeniz'e kaymış ve buranın malı olmuştur. Osmanlı İmparatorluğu; Batı Anadolu, Ege Denizi, Akdeniz Havzası, Suriye ve Kuzey Afrika'da yayıldıkça geniş zeytin alanlarını tasarrufu altına aldı. Kanunnameler, vakıf kayıtları, narh defterleri, tapu defterleri bu konularda zengin malzeme içermektedir. Osmanlı'dan önceki dönemle ilgili, Roma ve Bizans dönemlerine ilişkin kayıtlar dikkati çeker. Sözgelimi Suriye sancaklarında Zeytuni Romani, Roma ve Bizans dönemi zeytinliklerine işaret eder. Zeytuni İslami kaydı da, daha sonra dikilen zeytin ağaçlarını belirlemek için kullanılır. Bu deyimler, yalnızca Suriye sancaklarında vardır. Başka yerlerde görülmez.

Osmanlı İmparatorluğu'nun yayıldığı alanlarda, var olan zeytin üretiminde herhangi bir kesinti olmadı. Kaldı ki, İslam dünyası daha ilk zamanlardan başlamak üzere zeytini biliyordu. Hatta, Kur'an-ı Kerim de bir çok yararlı ağaç ve meyve arasında, sık sık zeytine ve zeytinden elde edilen yağa gönderme yapılır. İslam'ın yayıldığı, Akdeniz dünyasında zeytin ve zeytin kültürü önemli bir yer tutar. Bu kültür, geniş ölçüde işlenmiş ve değerlendirilmiştir.

Ege Adaları, Batı Anadolu, Akdeniz ve Suriye kıyıları, zeytinin bol yetiştiği yerler olarak görülmektedir. Türklerin yönetimi altına giren ülkelerde alışkanlıklar pek değişmemiş, daha önce var olan üretim/tüketim ilişkilerinde de köklü bir değişiklik olmamıştır. Yeni değişimlerin ülkeyi sarsacağından kaygı duyulduğu için bu yola başvurulmuştur. Ancak vergilendirme, pazarlama, işletme alanlarında yer yer müdahaleler olmuştur. Bundan 
ötürü adaların ve Girit'tin ekonomisinde büyük bir yer tutan zeytin ve zeytinyağı üretimi, varlığını korumuş ve sürdürmüştür. Zeytin meyvesinin daha doğrusu çekirdeğinin en belirgin özelliği, yağ çıkarılmaya elverişli olmasıdır. Tane olarak da tüketilir. Sabun üretiminin en önemli girdisi, zeytinyağıdır. Zeytinyağı, mutfakta yemeklik olarak kullanıldığı gibi çok geniş ölçüde, hassa ahırlarında da tüketilmektedir. Bu tüketim, at ve deve gibi hayvanların yağlanmasıyla ilgilidir. Elbette zeytinyağı çok geniş ölçüde, aydınlatmada da kullanılmaktadır.

Suraiya Faroqhi, klasik dönemde Ege ve Rumeli kıyılarında zeytinyağının yemeklik olarak tüketilip, tüketilmediğini sorgulamaktadır. Ancak saray mutfağıyla ilgili son yapılan araştırmalar, Fatih döneminden beri burada zeytinyağı tüketildiğini ortaya koymuştur. Osmanlı İmparatorluğu'nda haşhaş ekimi de, yağ çıkarmaya yöneliktir. Bu iş için yağhane ya da tahunhane denilen işyerleri vardı. Öte yandan Manisa'da, susam ziraatı oldukça gelişmişti. Bu bitkiden, şırlağan denilen bir yağ elde ediliyordu. Susam işleyen yağhaneler oldukça yaygındı. İç tüketim karşılandıktan sonra bu yağ, dışarıya da satılıyordu.

Zeytinin yetiştiği, tüketildiği yerlerde genellikle zeytinyağı değirmeni bulunur. Sözgelimi İzmir kazasında 1528 yılında, yedi köyde otuz üç değirmen taşı varken, 1575 yılında değirmen taşı bulunan köy sayısı, on ikiye, değirmen taşı sayısı da altmış altıya çıkmıştı. Tapu defterlerinde zeytinliklerden, zeytin ağaçlarından ve zeytin pazarından söz edilir, Girit'in fethinden sonra çok geniş zeytinlikler, Osmanlı yönetimine geçmiştir.

Zeytinyağının, Osmanlı mutfağında da yer tuttuğuna işaret ettik. İmaret tesislerine alınan zeytinyağları yalnız aydınlatma için değil, aynı zamanda mutfakta da yemeklik olarak tüketiliyordu. Prof. Dr. Robert Mantran, XVII. yüzyılda İstanbul'da Türklerin, etlerini ve ekmeklerini tatlandırmak için zeytinyağını bir çeşit sos olarak kullandıklarına dikkati çekmektedir. Biraz tuzla birlikte, tereyağı yerine ekmeğin üstüne sürerek de yenilmektedir. Eğer zeytinyağına biraz limon, ya da sirke ve karabiberle tuz katılıp birlikte karıştırılırsa, kimi balık türleriyle iyi giden bir sos elde edilmektedir. Kaldı ki, XVIII. yüzyılla ilgili arşiv belgeleri Midilli, Kolonya ve Molova kazalarından gelen yağların bir kısmının, ahalinin yemekliğine tahsis edildiğini açıkça ortaya koymaktadır. Zeytinyağının, dışarıya satılması yasaktı. Ancak zaman zaman dış satışına, izin veriliyordu. Sözgelimi, öteden beri Ağriboz'da bulunan Fransız tüccarları, satın aldıkları zeytinyağının gümrük ve diğer resimlerini ödüyor ayrıca, “beher kıyye için de üç akça resm-i miri” vererek zeytinyağını Fransa'ya götürebiliyorlardı. Bu zeytinyağı, Marsilya'da gelişmekte olan sabun sanayinin girdisini oluşturuyordu.

XVII. ve XVIII. yüzyıllarda, Batı Anadolu'da zeytinciliğin önemli bir gelişme gösterdiğine şüphe yoktur. Midilli'den gelen Rumların, XVIII. yüzyıl ortalarında Ayvalık’ı [Kidonya] 
kurmaları Batı Anadolu zeytinciliğine yeni ufuklar açtı. Ayvalık'ı çevreleyen zeytinlikler sayesinde, burası kısa sürede büyük bir zeytinyağı ve sabun üretim merkezi durumuna geldi. Bu ekonomik gelişmeye şarapçılık, dericilik ve tuz üretimi de eklenince daha geniş açılımlar sağlandı. Yine bu yörede dikilen zeytin ağaçları da önemlidir. Bununla ilgili kayıtlar, tapu defterine eklenmiştir. Bu kayıtlar, 1182 [1768-1769] tarihlidir ve yöreye binlerce zeytin ağacı dikilmiştir [TT 153, Karesi muhassılına ekli risale].

XVII. yüzyılla ilgili ‘Narh Defteri’nde, İstanbul piyasalarında Edincik ve Karaburun zeytinlerinden söz edildiği gibi zeytinyağından da söz edilmektedir. Prof. Dr. Robert Mantran'ın deyimiyle, "bir mide kent olan İstanbul'un iaşesi devleti ilgilendiren temel bir sorundu." XVII, yüzyılın ikinci yarısında çevresiyle birlikte, yedi yüz bin kişilik bir nüfusu barındıran İstanbul'un beslenmesi öncelikli sorunlardan biridir. Saray, saray hizmetlileri, ordu mensupları, vakıf görevlileri, medrese öğrencileri gibi bütün bunların iaşesinin sağlanması o günkü koşullara göre oldukça zordu. Kaldı ki İstanbul, bir tüketim merkezi olarak görülmektedir. Daha doğrusu İstanbul, birinci derecede önemli bir üretim merkezi değildir. 'Endüstri' burada az gelişmiştir. Beslenme için gerekli olan tahıl, pirinç, sebze, kuru ve yaş meyve, yağ, bal, kasaplık hayvan, İmparatorluğun çeşitli yerlerinden gemilerle, Haliç'teki iskelelere getiriliyor ve buralardan dağıtımı yapılıyordu. İmparatorluk, başkentin iaşesi için belirli bölgelere ayrılmış ve bu yerlerde elde edilen ürünlerin, İstanbul'a gönderilmesi için yükümlü kılınmıştı. Sözgelimi Mısır'dan pirinç, şeker ve baharat geliyordu. Kefe'den yüklenen sadeyağ ve peynir İstanbul'a ulaşıyordu. Limni ve Midilli'den beyaz peynir, Bursa'dan kestane, Ege kıyılarından sebze, yaş ve kuru meyve geliyordu.Tahıl için, İmparatorluk seferber edilmişti. Akdeniz kıyıları, Batı Anadolu, Marmara Bölgesi, Eflak-Boğdan, Karadeniz gibi yerler İstanbul'a buğday göndermekle yükümlü kılınmıştı. Midilli ve Ayvalık'tan İstanbul'a zeytinyağı gönderilmesine gelince; Başbakanlık Osmanlı Arşivi'nde bulunan bir belge [Cevdet, İktisat, no 1451] öteden beri Akdeniz canibinden İstanbul'a, zeytinyağı ve sabun gelen mahalleri teker teker sayar. Buna göre: Midilli'den zeytinyağı, sabun. Kazdağı'ndan zeytinyağı sabun. Girit Adası, Kandiye, Hanya, Resmo'dan zeytinyağı, sabun. Atina'dan, zeytinyağı, sabun. İzmir'den, sabun. Edremit'den, zeytinyağı. Molova'dan, zeytinyağı. Ayvalık'tan zeytinyağı. Cunda Adası'ndan zeytinyağı. Eğriboz'dan zeytinyağı. Bu listeden anlaşıldığına göre, Akdeniz'de çok geniş bir alanın zeytinyağı ve sabun ürünü İstanbul'un ihtiyacına tahsis edilmiştir.

Midilli, Anadolu kıyılarına oldukça yakın bir adadır. Ada, Cenevizlilerin elindeydi ve Osmanlılara vergi veriyordu. 1462 yılında Fatih tarafından, Osmanlı topraklarına katıldı. Suyu kendine yeterli olan ender yerleşim yerlerinden biridir. Bağ, zeytin ağaçları ve meşeliklerle kaplıdır. Bundan ötürü adada; zeytinyağcılık, şarapçılık ve balıkçılık oldukça gelişmiştir. Meşeliklerden, palamut elde edilir. Zeytincilikten ötürü Midilli, bir sabun üretim 
merkezidir. Adada, revgan-ı zeyt ve zift işliklerinin bulunduğu 'Midilli Kanunnamesi'nde yazılıdır. Kaldı ki Midilli'den, İstanbul'a zeytinyağı dışında Prof. Dr. Robert Mantran'ın da vurguladığı gibi zift, reçine, peynir ve gemi yapımında kullanılmak üzere kereste gönderiliyordu. Burada bir de, tuzla işletmesi vardı.

Midilli'nin zeytinyağı kaynakları, fetihten sonra bir mali kaynak birimi olarak mukataa haline getirildi. Zeytinyağı ihracı, İstanbul'a bağımlı kılındı. Adanın, Osmanlı yönetimine geçmesinden sonra, burada bulunan on manastır arazisi vergiden ve cizyeden muaf tutulmuş, buna karşılık saray ahırları için, zeytinyağı vermekle yükümlü kılınmıştır. 1790 yılında Midilli'yi gezen Olivier'in, Türkiye Seyahatnamesi kitabında burada üretilen 40.000 kental zeytinyağının tamamının İstanbul'a gittiğini yazmaktadır. [1 Kental 100 kg]. 1310/1893 salnamesine, Midilli'deki bir buçuk milyon zeytin ağacından yılda kırk beş milyon kilogram zeytin ve on iki milyon ton zeytinyağı elde edilmektedir. Midilli'den, İstanbul'a gönderilen zeytinyağının hangi gemilere ve ne ölçüde yüklendiği, arşiv belgelerinde ayrıntılı olarak yer almaktadır.

İstanbul'a, zeytinyağı ve sabun göndermekle yükümlü yerlerden birisi de Ayvalık'tı. Burası, 1818-1819 [1234] tarihinde başkente 27.900 kantar zeytinyağı ve 4.852 kantar sabun göndermeyi yükümlenmişti. Bu miktar “tamam olmadıkça bundan böyle mahall-i ahara bir vukiyye ve bir dirhem revgan-1 zeyt ve sabun verilmemesi” tenbih olunmuştu [Kantar: 44 eski okka= 56.41 kilogram; vukiyye: okka]. Ayvalık, 1821 ayaklanmasında tahrip edilmiş, sonra yine canlanmıştı.

Ayvalık'ın yanı başındaki Cunda [Alibey] Adası, [Cunda] Ayvalık’a değil Midilli'ye bağlıydı. Cunda Adası, İstanbul'a zeytinyağı ve sabun göndermekle yükümlüydü. Burası 800 kantar zeytinyağı, 400 kantar sabun sağlamakla yükümlüydü. Yunda'nın, Midilli'ye bağlı bir kaza olması, mutasarrıf Namık Kemal'in de bir türlü anlayamadığı bir şeydi. Ayvalık’a bağlanması yönünde yapılan bütün girişimler sonuçsuz kalmış ve Midilli'nin elden çıkmasına kadar bu durum devam etmiştir.

1877 yılında Midilli'de ikamete memur edilen Namık Kemal, 18 Aralık 1879 tarihinde sancağın mutasarrıflığına getirildi ve 1884 tarihine kadar bu görevde kaldı. Namık Kemal, burada büyük bir yönetici ve devlet adamı olduğunu kanıtladı. Saraya gönderdiği raporlar ve yazdığı mektuplar Midilli'nin sosyal, ekonomik durumuna ve özellikle adanın zeytinciliğine büyük bir ışık tutmaktadır. Ona göre adanın, birinci ürünü zeytin tarımıdır. Ada halkının geçimi zeytinciliğe ve bağcılığa bağlıdır. 1264 [1849] yılı kışının çok şiddetli geçmesinden ötürü, hemen hemen bütün zeytin ağaçları donmuş ve bundan sonra ağaçların köklerini üretken kılmak, yeniden zeytin yetiştirmek ya da yabani açıp aşılamak pek kolay olmamıştır. Bunun sonucunda, halk için bir de 'murabaha' belası çıkmıştır. 
Kısacası, zeytinciliği geliştirmek için uygulanan borç-faiz yöntemi pek verimli olmamış halk, sürekli olarak borç altında ezilmeye mahkûm edilmiştir. 'Menafi Sandıkları'nın kurulması gündeme gelmiş fakat istenen yarar sağlanamamıştır. Bilgisizlik ve parasızlık, MAARİF ve SERMAYE noksanı yalnız tarımda değil ticarette de kendini göstermektedir. Namık Kemal'e göre, zeytinciliği ilerletmek ve çöküşü durdurmak için yapılması gereken işlerin başında burada bir banka şubesi açmaktır.

İstanbul'a gönderilen, Ayvalık zeytinyağlarına kimi zaman pamuk yağı karıştırılıyordu. Bu durum, yönetimi ve zeytinyağı tüccarlarını güç durumda bırakıyordu. Ancak bu durumun, birkaç kez tekrarlandığı görülmektedir. Yani zeytinyağına, pamuk yağı karıştırmak neredeyse alışkanlık haline gelmiştir. Bu belgelerden birini örnek olarak buraya alıyoruz:

“Başbakanlık Osmanlı Arşivi DH MKT 1524/116, 13052015.

\section{Hüdavendigâr Vilayet-i Celilesine 10 Temmuz 1304}

Ayvalık mahsulünden, Dersaadet'e irsal edilen zeytinyağlarının pamuk yağıyla mahlut denilerek ihraç ve füruht ettirilmekte olduğundan ve halbuki Ayvalık'a pamuk yağı gelmediği cihetle yağları muayene eden etıbbanın muayenelerinde sehv vukubulduğundan bahisle icra-yı icabı hakkında bazı inhaları havi Ayvalık tüccarından müteaddit imzalarıyla gelen telgrafname üzerine Rüsumat Emanet-i Aliyyesiyle bilmuhabere emanet-i celileden yani Karasi namına Ayvalık’tan Galata gümrüğüne çıkarılan yirmi fuçu yağın bilmuayene on fuçusunun halis olduğu anlaşılmakla imrarına ruhsat verilip diğer on fuçusunun pamuk yağıyla mahlut idüğü tebeyyün etmesine mebni tevkif olunarak usulü veçhile gaz yağı karıştırılıp icabının icra olunacağı ve bununla beraber fuçuların sahibi tarafından bir fabrikaya satılmışlar ise... keyfiyetin tefhimi..."

\section{Zeytinyağında Tekelin Kaldırılması İçin Baskı}

Tekel daha doğrusu yed-i vahit sistemi, ürünün devlet tarafından alınıp satılması demektir. Prof. Dr. Mübahat Kütükoğlu'na göre, önce afyon üzerine konulan tekel daha sonra ipek, zahire, zeytinyağı, pamuk, tiftik, yapağı gibi diğer önemli ürünleri de kapsamına aldı. Yed-i vahit, gittikçe genişleyen Avrupa ticareti açısından bir ayak bağı olarak görülüyordu. İngilizlerin bu konudaki yakınmalarından biri de, Mısır Valisi Mehmet Ali Paşa'nın sistemi bütün Mısır'ı kapsayacak biçimde genişletmesidir. İngilizlerin esas amacı, kimi stratejik ürünlere uygulan tekelin yani yed-i vahidin kaldırılmasıydı. Bunun için İngiliz diplomatları, tekelin kötü bir uygulama olduğunu, kaldırılmasının halkın yararına olacağı tezini işlemeye başladılar. Osmanlı devlet adamlarını da buna inandırmaya çalıştılar. Ancak Osmanlı, sistemin kaldırıldığı takdirde yabancıların iç işlerine karışabileceğinden kaygı duyuyorlardı. 
Yed-i vahidin kaldırılmasıyla ilgili görüşmeler, 1254/1838 yılına kadar devam etti. Sonunda, Balta Limanı Antlaşması'nın dördüncü maddesi uyarınca kaldırıldı. Buna göre Britanya tebaası, Osmanlı ülkesinde üretilen bütün maddeleri, istisnasız olarak ihraç etmek iznini elde ediyordu. Bu madde aynen şöyledir: "Saltanatı seniyye gerek ziraat ve hırasetle hasıl olur ve gerek cemi eşyanın emri mübayaasını men eden yed-i vahit usulünün bilkülliye terk ve iptalini resmen taahhüt eyler."

Üzerinde durmak istediğimiz asıl nokta şudur: Yed-i vahitin 1838 Balta Limanı Antlaşması'yla kaldırıldığı bilinmekle birlikte böyle bir kararın çok daha önceden uygulamaya konulduğu anlaşılmaktadır. 18 Eylül 1833 tarihli bir belgede, "revgan-1 zeyt hususunda yed-i vahit usulü külliyen fesh ve hüsn-i nizamı istikmal olunmuş omağla..." denilmekte ve bunun o tarihte kaldırıldığı açıkça anlaşılmaktadır.

Zeytinyağının, "Der Aliyye tertibi fazlası” dışarıya ihraç edilebiliyordu. Bu yeni uygulama, İstanbul için gerekli olan zeytinyağı ve sabunun sağlanması konusunda bir takım yükümlülükleri de birlikte getiriyordu. İstanbul'a zeytinyağı sağlamakla yükümlü yerler şunlardı: Midilli, Yunda, Molova, Ayvacık, Emrutabad. Anlaşıldığına göre, İstanbul'a tahsis edilen zeytinyağı 150.000 kantardı.

\section{Sonuç}

Osmanlı İmparatorluğu, geniş bir alana yayıldığı için zeytinlikler de geniş topraklar işgal ediyordu. Zeytin, zeytinyağında üretim ve tüketim ilişkilerinde tarihin derinliklerine giden bir mirası devralmış ve sürdürmüştür. Öyle ki Osmanlı egemenliğinde bulunan Kuzey Afrika, Batı Anadolu, Doğu Akdeniz ve adalarda zeytincilik kültürü varlığını devam ettirmiştir. Zeytin, zeytinyağı üretimi, vergilendirilmesi, pazarlanması belirli kurallara bağlanmış ve kurallar kanunnamelerde açıklanmıştır. Adalarda ve Ege Bölgesi'nde üretilen zeytinyağının ve sabunun İstanbul'a tahsis edilmesi, başkentin ihtiyacını karşılamaya yöneliktir. Adalar içinde Midilli, önemli bir merkezdir. Anadolu'da, Ayvalık onu izler.

İngilizlerin direnmesi sonucu, 1838 Balta Limanı Antlaşması'yla zeytinyağında tekel usulü kaldırıldı. Ancak, arşiv belgelerine göre, zeytinyağında bu tekel daha önce kaldırılmıştı. İstanbul için gerekli olan zeytinyağı ve sabunun sağlanması için gerekli önemler alınmıştır. 


\section{Kaynakça}

Adıyeke, Nükhet. Osmanh Imparatorluğu’nda Girit Bunalımı, 1896-1908, TTK, Ankara, 2000.

Altnay, Ahmet Refik, On İkinci Asr-ı Hicri'de İstanbul Hayatı [1689-1785], İstanbul, 1930.

Arıkan, Zeki. “1821 Ayvalık İsyanı”, Belleten, 203, 1988.

Arıkan, Zeki. "Osmanlı İmparatorluğu'nda İhracı Yasak Mallar [Memnu Meta]", Bekir Kütükoğlu Armağam, İstanbul, 1997.

Arıkan, Zeki. "Midilli-İstanbul Arasında Zeytinyağı Ticareti", Tarih Araştırmalan Dergisi, XXV/2006, sayl: 40 .

Ayoğuz, Şengül. Cezayir-i Bahr-i Sefid Vilayeti, Ege Üniversitesi Sosyal Bilimler Enstitüsü, Yüksek Lisans Tezi, 1989.

Bahr-i Sefid Kilavuzu [Adalar Denizine Ait], İstanbul, 1331, İngilizceden çevrilmiştir.

Bağış, Ali İhsan. Osmanh Ticaretinde Gayri Müslimler, Kapitiulasyonlar, Avrupa Tüccar, Berath Tüccarlar, Ankara, 1983.

Balta, Evangelia. L'Eubée á la fin du XVI siécle. Economie et Population. Les registres de l'année 1474, Athens, 1,1989 .

Balta, Evangelia. "Olive Cultivation in Crete at the time of the Conquest" Osmanh Araştrrmalan/Fournal of Ottoman Studies, XX, 2000.

Balta, Evangelia.-Oğuz, Mustafa. Liva-i Resmo Tahrir Defteri, TTK, Ankara, 2009.

Barkan, Ömer Lütfi. XV-XVI. Asirlarda Osmanh İmparatorluğu’nda Kanunlar I, İstanbul, 1943.

Barkan, Ömer Lütfi. "Edirne Civarında Bazı İmaret Tesislerinin Yıllık Muhasebe Bilançoları”, Belgeler, $\mathrm{I} / 2,1964$.

Braudel, Fernand. La Méditerrenaée et le monde méditerrenéen á l'époque de Phililippe II, Paris, 1966, 2 vols.

Boulanger, Patrick. Marseille marché international de huile d'olive, un produit et des hommes, Marseille, Institut Historique de Provence, 1996.

Boulanger, Patrick. "L'ile de Mytilène et le négoce français au XVIIIe siecle", Les villes dans l'Empire Ottoman: Activités et Sociétés, Paris, 1991, I.

Cornelius le Brun. Voyage au Levant, Rouen-Paris, 1728, I.

Darkot, Besim. 'Midilli', İslam Ansiklopedisi, VIII.

Darkot, Besim. 'Ayvalık', İslam Ansiklopedisi, II.

Dukas. Bizans Tarihi [çev. V. L. Mirmiroğlu], İstanbul, 1956.

Emecen, Feridun M. "Ege Adaları'nda Mali Yapı", Ege Adalarn'nda İdari, Mali ve Sosyal Yapr [ed. İdris Bostan], SAEMK, Ankara, 2003.

Erim, Hıfzı. Ayvalk Tarihi, Ankara, 1948.

Evliya Çelebi Seyahatnamesi, İstanbul, 1935, IX.54-55.

Faroqhi, Suraiya. "Rural society in Anatolia and the Balkans during the sixteenth century", Turcica, IX/1, 1977.

Faroqhi, Suraiya. Osmanli'da Kentler ve Kentliler, Tarih Vakfi, İstanbul, 1993.

Faroqhi, Suraiya ve NEUMANN, Christoph K. [ed.], Soframz Nur Hanemiz Mamur Osmanl Maddi Kültüründe Yemek ve Barnnak [çev. Zeynep Yelçe], Kitap Yay., İstanbul, 2006. 
Frangakis-Syrett, Elena, The Commerce of Smyrna in the Eighteenth Century (1700-1820), Athens, Centre for Asia Minor Studies, 1992.

Güçer, Lütfi. "XVII. Yüzyıl Ortalarında İstanbul'un İaşesi için Lüzumlu Hububatın Temini Meselesi”, Íktisat Fakültesi Mecmuası [IFM], XI/1-4, 1949-1950.

Güçer, Lütfi. "XV- XVII. Asırlarda Osmanlı İmparatorluğu’nda Tuz İnhisrı ve Tuzlaların İşletme Nizamı”, IFM, 23, 1961-1963.

Hinz, Walther, Islamische Masse und Gerwichte, Leiden, 1955.

İnalcık, Halil. Ottoman Empire, The Classical Age, 1300-1600, London, 2003.

İnalckk, Halil. 'İmtiyazat', Encyclopedia Of Islam 2, IV.

Kalodny, Emile. La Population des İles de la Grece, Aix-en-Provence, 1974, I.

Kritovulos. Tarih-i Sultan Mehmed-i Han-ı Sani [çev. Karolidi], İstanbul, 1328.

Örenç, A. F., Ege Adalarnmn Egemenlik Devri Tarihçesi, [F. Emecen, İ. Bostan, İ. Şahin, V.

Engin, M. Oğuz, Ö. İşbilir ve F. Yılmaz’la, birlikte], ed., C. Küçük, SAEMK, Ankara 2001.

Kütükoğlu, Mübahat S. Osmanllarda Narh Müessesi ve 1640 Tarihli Narh Defteri, Ende ᄀrun, İstanbul, 1983.

Kütükoğlu, Mübahat S. XV ve XVI. Astrlarda İzmir Kazasinnn Sosyal ve İktisadi Yapısl, İzmir, 2000.

Kütükoğlu, Mübahat S. Osmanl-İngiliz İktisadi Münasebetleri [1580-1838], Ankara, 1974, I.

Lowry, Heath W. Fifteenth Century Ottoman Realiyies Christian Peasant Life on the Aegean Islands of Limnos, Eren, İstanbul, 2002.

Mantran, Robert\&Sauvaget, Jean. Règlements fiscaux ottomans Les provinces syriennes, Beyrouth, 1951.

Mantran, Robert. Istanbul dans la second moitié du XVII e siècle, Paris, 1962.

Masson, Paul. Histoire du Commerce français dans le Levant au XVIIe siecle, Paris, 1896, 1911.

Olivier, Türkive Seyahatnamesi [çev. Oğuz Gökmen], II. Kitap, İstanbul, 1991.

Planhol, Xavier de. De la plaine pamphylienne aux lacs pisidiens, Nomadisme et vie paysanne, Paris, 1958.

Planhol, Xavier de. Les fondements géographiques de l'histoire de l'Islam, Paris, 1968.

Tansel, Fevziye Abdullah. Namık Kemal'in Hususi Mektuplar, TTK, Ankara,1973.

Tengirşenk, Yusuf Kemal. "Tanzimat Devrinde Osmanlı Devleti'nin Harici Siyaseti”, Tanzimat I, İstanbul, 1940.

Uluçay, Çağatay. XVII. Yüzyllda Manisa'da Ziraat, Ticaret ve Esnaf Teşkilat, İstanbul, 1942.

Ünal, Ayhan Afşin. XVI. Yüzyllda Midilli Sancağr, Erciyes Üniversitesi Sosyal Bilimler Enstitüsü, Doktora Tezi, 2001.

Yerasimos, Stefanos. Sultan Sofralar, XV-XVI. Yüzynllarda Osmant Saray Mutfă̆ı, YKY, İstanbul, 2001.

Yorulmaz, Ahmet. Ayvalık’ Gezerken, Ayvalık, 2000, s. 56-57. 


\section{Dünyanın İştahını Kabartan İki Renk, Bir Kent: "Zeytin Yeşili, Zeytinyağı Sarısı ve İzmir"}

\section{Doç. Dr. Cihan ÖzGÜN}

Ege Üniversitesi Öğretim Üyesi

İzmir ve çevresindeki bereketli topraklar... Büyük çiftlik sahipleri, köylü, tüccar, hamal, deveci ya da altın ağacından zeytin toplayan işçiler... Bereketli toprakların zenginliğini sırtında taşıyan develer... Vagonlarından yağ damlayan trenler... Altın sarısı zeytinyağına doymak bilmez gözlerle bakan tüccarlar, ortaklar, simsarlar, ithalatçılar, ihracatçılar... Gelişen, büyüyen, değişen insanlar ve alışkanlıklar içinde, XIX. yüzyılın ikinci yarısında İzmir ve çevresinde zeytin, zeytinyağı...

\section{Osmanlının Araladığı Kapı 'Tanzimat': Toprak ve Üretim Düzeninde Yeni Gelişmeler}

Tanzimat'tan hemen sonra Osmanlı dünyasında devlet-köylü ilişkileri, klasik dönemden farklı olarak değişmeğe başladı. Bu değişimi tetikleyen nedenlerden belki de en önemlisi, tarımın ticarileşmesi oldu. XIX. yüzyılda hızla sanayileşen Avrupa ülkelerinin tarımsal ürün talebindeki artış, tarımın ticarileşmesini de beraberinde sürükledi. Devletin köylüye ve köylü sorunlarına yaklaşımı, klasik dönemden farklı olarak daha belirgin bir hal aldı. Örneğin devlet, köylüyü klasik dönemde olduğu gibi üç yıl üst üste toprağını ekmeyince cezalandırma yöntemini uygulamaktan vazgeçti. Tanzimat'tan sonra devletin nazarında halk artık reaya değil; üreten, sorumluluk üstlenen bir konuma ulaştı ve devlet de bunu yaptığı yeni düzenlemelerle fark ettirdi. Tanzimat'la birlikte Osmanlı Devleti, taşrada Ziraat Müdürlüklerini kurarak, çiftçiye gübre ve tohum yardımı yaparak, köylüye kredi verilmesini sağlayarak, köylüyle olan ilişkilerinde yeni düzenlemelerde bulundu. Tanzimat'ın tarımsal üretimi teşvik amacıyla getirdiği ilk ve en önemli değişimlerden biri, tarımsal ürün ticaretinin serbestleştirilmesi oldu. Böylece tarımsal ürünlerin devletçe tespit edilen fiyatlarla satın alınması yani miri mübayaa usulü kaldırıldı, herkesin ürününü istediği yerde ve piyasa fiyatlarıyla satabilmesi esası getirildi. ${ }^{1}$

Tanzimat döneminde sosyal ve idari reformlarla, modernleşmeyi ve bu reformların başarısını ekonomik gelişme alanında atılacak adımlarla desteklemeyi hedef alan bir

1 İsmail Arslan, XIX. Yüzynlda Bahkesir'de Tarmsal Üretim ve Köylüler, Basılmamış, Yüksek Lisans Tezi, Balıkesir 2004, s. 99-105. 
yönetim anlayışı doğdu. Bu anlayışın politikalarını oluşturacak olan tarımsal bürokrasi de kuruldu. Yeni dönemin yeni hedefleri; üretimin ve çeşitliliğin arttırılması, dış talebe yönelik üretimin teşvikiyle dış ticaret dengesinin sağlanması, yerli sanayinin ihtiyacı olan hammaddenin yurtiçinde üretilmesi, araç ve metotların modernleştirilmesiydi. Böylelikle Osmanlı tarımı, 'devletin de desteğiyle' ülke genelinde belli bir gelişme ve yapısal bir değişim sürecine girdi. Bu sürecin elbette başka iticileri de vardı. ${ }^{2}$ XIX. yüzyılda Osmanlı İmparatorluğu ekonomisi tarıma bağımlıydı, vergilerin büyük çoğunluğu tarım kaynaklı olup ihracatın çoğunluğu da tarım ürünlerinden oluşuyordu. ${ }^{3}$ Devlet tarımsal üretimin ürünlerinden yalnızca ticarete konu edildiğinde veya pazara sunulduğunda vergi alıyordu. Bir çiftçi evinin bahçesinde veya sahip olduğu toprağın küçük bir bölümünde yaptığı tarımsal üretimden dolayıı vergi ödemiyordu. Tanzimat’a kadar tarımsal ürünlerden alınan verginin ölçü birimi ve miktarı da sancaktan sancağa değişiklik gösteriyordu. ${ }^{4}$ Tanzimat sonrasında hangi türden olursa olsun, kırsal araziler için ödenmesi gereken vergiler içinde yetiştirilen tüm ürünlerin, 1/10'undan alınan öşür vergisinin yanı sıra arazinin ve üzerindeki çiftlik binalarının yaklaşık değerinin 1/1000'inden yıllık kesilen vergi, bu eşitsizliği kısmen de olsa giderdi. Bunlardan başka şehirlerdeki binalarınsa yaklaşık değerinden, yıllık 8/1000 vergi alımı da söz konusuydu. ${ }^{5}$

XIX. yüzyılın ortalarında Batılı ekonomik sistemlerin, Osmanlı ülkesindeki etkileri değişik bölgelerde ve değişik düzeylerde ortaya çıktı. Bir başka deyişle, farklı özellikleri olan bölgeler kapitalist ilişkilerden görece eşitsiz oranda etkilendi. Bu etkilenmede, İzmir ve art alanı bu eşitsizliğin en üst noktasına erişti. Kapitalist ilişkiler, tarımda belli bir ticarileşmeyi gerektirdi bu da, tarımsal üretimin tahıl ve diğer geçimlik ürünlerden sanayi hammaddelerine ve diğer pazar ürünlerine doğru kaymasına neden oldu. Osmanlı

2 Olcay P. Yapucu, Modernleşme Sürecinde Bir Sancak: Aydın, İstanbul, 2007, s. 67-68.

3 Donald Quatert, "Osmanlı İmparatorluğu'nda Tarımsal Gelişme”, Tanzimat'tan Cumhuriyet'te Türkiye Ansiklopedisi, C. IX, 1985, s. 1556-1562.

4 Bu durum Osmanlı Kanunnamesi’nde, “... sebzeden ve meyveden kendi maişetleri için olmayup, bazara getürüp satılırsa, sahib-i arza defterde öşr-i bostan ve meyve hasıl kaydolunan ösrr-i sebze ve meyve alınur...” şeklinde belirtilmekteydi. Örneğin Kanuni döneminde, Umumi Osmanlı Kanunamesi’nde bağclıktan alınacak öşürle ilgili şöyle denilmekteydi: “... Bağ dönümüne bazı vilayette on akçe ve bazı vilayette beş akçe alinı. Ve hadaikdan ve harimlerden dahi öşüllerine göre kesim alını. Amma bazı yerlerde bağın dönümüne yedişer ve bazı yerlerde sekizer ve bazı yerlerde onar akçe alını. Bağdan ve bağçeden össr-i hasıl alınmak kanuna ve şer'a mutabıkdır..." Kanunname'de de belirtildiği gibi alınacak verginin miktarının belirlenmesinde farklı yollar izlenmekteydi. Bazı sancaklarda kök başına, bazı sancaklarda dönüm başına, bazı sancaklardaysa kıta başına öşür alınıyordu. Tanzimat'tan sonra yapılan yeni mali düzenlemeyle ziraatı yapılan ürünlerden $1 / 10$ oranında öşür alınacağı, "her bölgenin verim gücü dikkate alnarak değişik oranlarda tahsil edilen öşrün lafiz ve manasina uygun olarak her tarafta onda bir hesabryla alınması" kanunlaştırıldı. İbrahim Solak, "Osmanlı İmparatorluğu Döneminde Anadolu'da Meyve ve Sebze Üretimi”, Tiurkiyat Araştirmalan Dergisi, sayı: 24, 2008, s. 220 ve 222.

5 S. Stab, "Tenure And Produce Of Land In The Province Of Smyrna", Journal Of The Society Of Arts, 12 November 1880, s. 919-920. 
tarımında tahıl, üretimin önemli bir parçası olduğu için toplam üretimde ve ihracatta her zaman önemli bir yere sahip oldu. ${ }^{6}$ Ancak buna rakip olacak, meyankökü gibi yeni ürünlerin de önem kazandığını da gözardı etmemek gerekir. Sözü edilen yüzyılın ortalarında, İzmir ve yakın hinterlandında tarım birincil önemli bir geçim kaynağı olmayı sürdürdü. Bölge tarımı değişen ve gelişen ekonomik koşullara bağlı olarak hızla ticarileşerek, kapitalist dünya ekonomisine uyum sağlama konusunda başarılı bir çizgi yakaladı.

Tanzimat dönemi idari reformlar, ülkenin kalkınmasında ve tarımsal gelişmesinde büyük bir paya sahip oldu. Bu amaçla, Tanzimat döneminde önceleri Hariciye Nezareti'ne bağlı olarak Ziraat ve Sanayi Meclisi adıyla kurulan ve sonra Ticaret Nezareti'ne bağlanarak Meclis-i Umur-u Nafia adını alan kuruluş oluşturuldu. Bu kurum, zirai gelişmeyle ilgili konuları ve bu alanda verilecek imtiyazları görüşerek karara bağlamakla görevlendirildi. Aynı zamanda her yıl vilayetlerde toplanan, Vilayet Genel Meclislerinin düzenleyeceği ve o bölgenin ekonomik gelişmesiyle ilgili tekliflerinin yer alacağı raporları düzenleyerek gereğini yerine getirmek bu kurumun başlıca görevleri arasındaydı. ${ }^{7} 1843$ yılında Maliye Nezareti'ne bağlı olarak kurulan Ziraat Meclisi'nin ilk önemli çalışması, Meclis-i Vala-yı Ahkam-1 Adliye'de hazırlanan ve Meclis-i Ziraatta görüşülen, tarım ve sanayinin geliştirilmesi, yol ve nehir ulaşımı gibi altyapı yatırımlarının yapılması, üreticilerin kredi ihtiyaçlarının karşılanması gibi konuları ele alan bir program oluşturdu. Bu program çerçevesinde, her eyalete bu konuda alınacak tedbirleri bildirmelerini isteyen yazılar gönderildi. Bu buyrultuda sancaklara bağlı kazalarda hangi ürünlerin yetiştirildiği, ulaşıma elverişli akarsu olup olmadığı, sanayi geliştirmek için hangi tedbirlerin alınabileceği ve bu konuda ahalinin ne gibi alet ve edevata ihtiyacının olduğunun, mecliste etraflıca görüşülerek layiha şeklinde sunulması ve üreticinin borçlanması ve faiz konularında ele alınacak kararının bildirilmesi istendi. ${ }^{8} 1846$ yılında müstakil bir Ziraat Nezareti'nin kurulmasıyla, zirai işlerle ilgili sorumluluk kısa bir süre için ayrı bir kurumsal varlığa sahip oldu. 1850’li yıllar boyunca tarımsal işlerle Nafia Meclisi ilgilendi. 1860'ların sonlarında ayrı bir Ticaret ve Ziraat Nezareti'nin kurulması, tarımsal meselelerden sorumlu olan daimi bir gurubun ortaya çıkmasını sağladı. ${ }^{9}$

1858 Arazi kanunnamesi, gelişen ve hızla kurumlaşan tarım bürokrasinin faaliyet alanının yasal zeminini hazırladı. Arazi kanunuyla arazinin el değiştirmesi, yeni binaların

6 Şevket Pamuk, Osmanh Ekonomisinde Bağımllhk ve Büyüme [1820-1913], İstanbul, 1994, s. 97.

7 Türk Ziraat Tarihine Bir Bakış [Bundan sonra TZTB], İstanbul, 1938, s. 204.

8 Hilal Ortaç, Tanzimat'tan Birinci Meşrutiyet'e Manisa, [Basılmamış Doktora Tezi], Ege Üniversitesi Sosyal Bilimler Enstitüsü, İzmir, 1996, s. 59-60.

9 Donald Quataert, Anadolu'da Osmanlı Reformu ve Tarm [1876-1908], çev. N. Gündoğan-A. Gündoğan, İstanbul, 2008, s. 87. 
inşası, eskilerin yıkılması, genel olarak mevcut düzenin bozulması için devlet iznini gerektiren maddeler yer aldı. Ayrıca ürün çeşitliliğine yönelik, yasal düzenlemeler de yapıldı. Arazi kanunnamesinin 25. maddesinde, toprağın kullanımına ilişkin hüküm yer aldı. Bu hükme göre, örneğin tahıl ekiminden üzüm bağına geçilmesi gibi değişikliklerin, sicil dairesinin onayını gerektirdiği belirtildi. Fakat yasadışı olarak dikilmiş ve olgunlaşmış bağ kütükleri ya da ağaçlar, fark edildikleri zaman olgunlaşmışlarsa kalmalarına izin verildi. Devletin gözünde bunların yok edilmesi, üreticinin izin almamasından çok daha büyük kötülüğe neden olacaktı. Bu tedbirlerden de anlaşıldığı üzere, devletin temel kaygısı arazilerin ekilip biçilmeden boş kalmasını engellemekti. ${ }^{10}$

Ziraat Meclisi'nin bir kararı da taşrayla ilişkileri güçlendirmek için, temel görevleri ekonomik gelişmeyle ilgili teklifler iletmek olan, Anadolu ve Rumeli'de bölgenin vücuh ve hanedanı arasından mahalli meclisler aracılığıyla seçilecek ziraat müdürleri tayiniydi. ${ }^{11}$ Ziraat Meclisi bu amaçla, ülkenin gerekli görülen yerlerine maaşsız olarak halktan birer Ziraat Müdürü tayinini önerdi. Müdürler, her bölgenin merkez niteliğindeki kazalarına tayin edilecekti. Müdürlerin temel görevleri, bulundukları bölgenin ekonomik gelişmesi için yapılabilecek çalışmalar hakkındaki tekliflerini Ziraat Meclisi'ne bildirmekti. Ayrıca, çiftçilerin üretimi arttırma ve çeşitlendirme çalışmalarına destek olacaklardı. Önerilerin kabulü üzerine, Anadolu'da yirmi ve Rumeli'de on kaza da mahallî meclisler tarafından, çoğunluğu bölgenin vücuh ve hanedanı arasından seçilen ziraat müdürleri, Ziraat Meclisi'nin onayıyla görevlerine başladı. ${ }^{12}$ Ziraat müdürlerinin vezaifine dair talimat'da, icabına göre envai hububat ve kök boya ve penbe ve arazinin tabiat ve kabiliyetine göre yetiştirilmesi lazım gelen sair şeylerin husule getirilmesine gayret etmeleri istendi. ${ }^{13}$

Tanzimat Dönemi'nde, taşra açısından tarımsal gelişme çalışmalarının bir diğer önemli sonucu da, Nafia Hazinesi'nin kurulması oldu. Bu hazineden sadece, 1843-1846 yılları arasında devlet tarafından çeşitli bölgelerin çiftçilerine on iki buçuk milyon kuruşu aşan miktarda kredi dağıtıldı ve yine bunun devamında, halktan tahsil edilecek kredilerin halkın ihtiyacı olan yol ve köprü yapımı ve onarımında, halkın kredi taleplerinin karşılanmasında kullanılması kararlaştırıldı. 1868 yılında kurulan Nafia Dairesi'ne aynı yıl içinde ulaşan raporlarda; okul, yol ve liman yapımı, bataklıkların kurutularak tarıma elverişli hale getirilmesi, sulama tesisleri inşası, bazı vergilerin kaldırılması ya da oranlarının düşürülmesi, zirai işgücü ihtiyacının karşılanması için tedbir alınması, kıtlık nedeniyle

10 Donald Quataert, age, s. 58-62.

11 Hilal Ortaç, agt, s. 60.

1212 Tevfik Güran, “Tanzimat Döneminde Tarm Politikast [1839-1876]”, Türkiye'nin Sosyal ve Ekonomik Tarihi [1071-1920], Ed. Osman Okyar-Halil İnalcık, Ankara, 1980, s. 271-272.

13 Ziraat Müdürlerinin Vezaifine Dair Talimat”, Düstur, T. 1, G. 2, 27 Ocak 1864, s. 434. 
doğan kredi ihtiyaçlarının karşılanması, hayvan hastalıklarının önlenmesi, panayır ve pazar gibi ticaret yerleri kurulması, göçebe toplulukların yerleşik tarıma verdikleri zararların önlenmesi; fabrika yapılması, modern tarım aracı, iyi cins tohumluk ve daha önce üretimi yapılamayan pazara dönük bazı ürün çeşitlerinin tohumunun gönderilmesi gibi çok çeşitli tekliflerde bulunuldu ve bu teklifler, Şûra-yı Devlet'de görüşülerek bir kısmının gerçekleştirilmesi için harekete geçildi. ${ }^{14}$

Anadolu tarımını geliştirmeye yönelik yerli çabalar, büyük ölçüde Osmanlı hükümetinin elindeydi ve 1876 yılında İstanbul ve taşrada Ticaret ve Ziraat Cemiyetleri kuruldu. Her bir cemiyet mahalli olarak seçilmiş üyelerden oluşacaktı. İstanbul'da on dört, vilayet merkezlerinde sekiz ve kazalarda dörder kişi seçilecekti. Maaşlı olmayan bu üyeler, her bölgenin önemli ziraatçıları ve tüccarları arasından seçilecekti. 1880 yılındaysa Sadrazam Said Paşa, İstanbul ve vilayetlerde ziraat odalarının kurulması emrini verdi. Üyeleri, bölgelerin önde gelen üreticileri ve nitelikli adamlarından seçiliyordu. Ayda iki kez yapılan toplantılarda, tarımsal gelişimi yavaşlatan etkenler ve tarımın gelişmesi için alınması gereken önlemler, yerel koşullara uygun türleri saptamak için tahıl, sebze tohumları ve bunların yanı sıra meyve ağaçları inceleniyordu. ${ }^{15}$ Ziraat Odaları; ziraat, baytar ve fen memurlarıyla faaliyet gösterdikleri bölgelerde, tarım hakkında teknik ve fenle ilgili bilgiler veriyorlardı. Görevleri arasında lise ve ortaokullarda ziraat dersleri okutmak, isteyen arazi sahiplerinin tarlalarında tarım teknik ve yöntemlerini köylüye uygulamalı olarak anlatmak, konferans tarzında genel ziraat dersleri vermek, çeşitli tohumların ıslah edilmesini göstermek, yeni tarım makinelerinin kullanılmasını ve bitki hastalıklarının tedavilerini köylülere göstermek, bütün tarım ürünlerinin istatistiğini düzenlemek ve tüm bunların yanı sıra tarımsal üretimin gelişmesine yardımcı olan bütün tedbirleri yerine getirmek vardı. Ziraat Odaları aynı zamanda panayır ve yarışmalar düzenlemek gibi önemli görevlerde üstleniyordu. ${ }^{16}$

Osmanlı'nın, Tanzimat'tan beri tarımsal düzenin modernleştirilmesine yönelik sarf ettiği çabalar İzmir ve çevresinde uygulanan tarım reformu örneğinden hareketle, bu sürecin/ çabaların merkez ve taşrada başarıya ulaştığını gösterdi. Osmanlı Bankası'nın krediler vererek tarımsal üretim sürecinde köylüye destek vermesi, patates, pirinç gibi İzmir'in ithal malları arasında yer alan ürünlerin bölge içinde üretilmesi için aralıklı olarak aşar vergisinden muaf tutulması, hükümetin gül tarımını desteklemek için ücretsiz gülfidanı dağıtması ve benzeri örnekler, bu politikanın başarıyla sürdürüldüğünü ortaya koymak-

14 Tevfik Güran, "Ziraî Politika ve Ziraatte Gelismeler 1839-1876", 150. Yilinda Tanzimat, haz. Hakkı Dursun Yıldız, Ankara, 1992, s. 220-221.

15 Donald Quataert, age, s. 79-80.

16 Osmanh Ziraat ve Ticaret Gazetesi, 9 Teşrinisani 1908. 
taydı. ${ }^{17}$ İzmir ve çevresinde tarımsal üretim ve ticaretini en çok etkileyen hastalıkların başında gelen bir bağ hastalığı olan filokseraya karşı verilen mücadeleler ve durumun incelenmesi için İzmir, Saruhan, Denizli ve Aydın Sancakları başta olmak üzere bölgeye ziraat öğretmenlerinin tayin olunması, ücretsiz Amerikan asma çubuklarının çiftçiye dağıtılması, bu asma çubuklarının dikileceği toprakların devlet tarafından muayenesi, tarım reformunun taşrada başarıyla sürdürülmeye çalışıldığını gösteren örnekler arasında yerini aldı. ${ }^{18}$ İzmir ve yakın artalanında toprak sahipleri, tarımsal etkinliklerinde kullanacakları yeni tarım aletleri veya tarımsal üretim sırasında karşılaştıkları hastalıklarla mücadelede sırasında hükümet tarafından kaza ve sancaklara gönderilen fen me-murları ve ziraat öğretmenleri tarafından bilgilendirilmeye çalışıldı. ${ }^{19}$

Ülke genelinde özellikle sanayi ürünleri başta olmak üzere uluslararası piyasanın taleplerine cevap verebilecek dereceye gelmesi için belli başlı ürünlerin yetiştirilmesinde üstün gayretleri görülen çiftçiler devlet tarafından madalyayla ödüllendirildi. Örneğin, on dönüm gülistan yetiştirenler dahi [diğer muafiyetlerden başka] bakır; yirmi dönüm kadar yetiştirenler gümüş ve kırk dönüm kadar yetiştirenler dahi altın ziraat madalyası aldı. ${ }^{20}$ Bu sadece Osmanlı devleti tarafından değil, yabancı sermaye sahipleri tarafından da uygulandı. Ülke genelinde artan pamuk hasılatı yüzünden fazlasıyla memnun olan İngiliz pamuk şirketleri pamuk üretiminin artışına katkısı olanları madalyayla onurlandırdı. ${ }^{21}$ Pamuk üretiminin artması başta İngilizler olmak üzere büyük yabancı sermaye guruplarını o kadar memnun etmişti ki, Asia Minor Cotton Company pamuk ziraatı konusunda yapmış oldukları teşvikten dolayı Ticaret Nazırı ve müsteşarına birer nişan gönderdi. ${ }^{22}$

XX. yüzyılın başlarında Osmanlı Devleti yüksek tarımsal üretim için gerekli koşulları sağlama yolunda dikkate değer başarılar elde etti. Osmanlı hükümeti 1907 ve 1909 yıllarında çiftçilik üretiminin bileşimi, tarım işletmelerinin özellikleri, üretim teknikleri, üretim girdileri ve benzerleri konularının yer aldığı iki istatistik araştırması yaptırdı. 1907 yılında imparatorluğun Avrupa ve 1909 yılında Asya ve Afrika toprakları için hazırlanan Ziraat İstatistikleri basıldı. ${ }^{23} 1907$ yılında Osmanlı Ziraat ve Ticaret Gazetesi çıkarılmaya

\footnotetext{
17 Accounts and Papers, Vol. 116, Smyrna, 1908, s. 4.

18 B.O.A., DH.MKT., 634/25 [1908].

19 Ahenk, 3 Ağustos 1901.

20 B.O.A., İ.OM. 5/ 1316. [1899].

21 B.O.A., İ. HR 219 /12721. [1865]; B.O.A.,̇. DH 533/36960 [1864].

22 B.O.A., A. MKT. MHM $325 / 2$ [1864].

23 Hüseyin Haşimi Güneş-Cahit Aydemir, "Türkiye'de Tarım Topraklarının Mülkiyet Yapısı ve Tarihsel Süreçteki Değişimde Diyarbakır Örneği”, Dicle Üniversitesi Sosyal Bilimler Dergisi, c. 3, s. 12, Bahar 2005, s. 78.
} 
başlandı. Gazete, bölgenin tarımsal üretim etkinliklerinin artırılması ve çağdaş bir görünüm kazanması için büyük çabalar harcadı. Avrupa'daki tarım ve ticaret üzerine gelişmeleri, modern tarım makinelerini, tarıma ilişkin yayınları, kullanılması önerilen tohum ve gübrelerin getirilmesine aracllık etti. Tarım makinelerinden hangisinin çiftçinin toprağına daha uygunsa muayene ederek müşterilere tavsiye etti ve isteyenlere gönderdi. ${ }^{24}$

Bölgede görev yapan ziraat müfettişleri, müdürleri veya tarıma ilişkin bürokrasideki resmi görevlilerin tarımın modernleşmesi ve tarımda yeni tekniklerin uygulanabilmesini sağlayan çabaları da büyüktü. Amasyan, Zakaryan, Bekyan Efendi gibi birçok yetkili isim, İzmir ve çevresinin tarımsal etkinliklerinin modernleşmesine ilişkin dikkate değer çalışmalar yaptı. Örneğin, XIX. yüzyllın sonlarında İzmir Ziraat Müfettişi olarak görev yapan Bekyan Efendi, İzmir ve hinterlandında gübre kullanımını artırmak için büyük çabalar harcadı. Tüm bu çabalara rağmen istenen sonuca ulaşılamadıysa da, bu konuda Ziraat Mektebi öğrencilerinin aldığı eğitimle çiftçinin bilinçlendirilmesi ümidi korunmaya devam etti. ${ }^{25}$ Yeni tarım araçlarının anlatılmaya ve tanıtılmaya çalışılmasıyla, çiftçiyi kullandıkları alat ve edevat ezmine-i kadimeden menkul saban, tırmık, sürgüden kurtarmak için XIX. yüzyılın sonlarında Ziraat Müdürü ve müfettişleri tarafından hala büyük bir mücadele veriliyordu. ${ }^{26}$

Osmanlı Devleti'nin tarımsal üretimine ilişkin uluslararası ilk ciddi sınavını, 1851 tarihinde verdi. Sanayi devriminin yol açtığı gelişmeler sonucu hızlı üretim artışı ve çeşitlerinin çoğalmasıyla, sanayi ürünlerinin ve üretim araçlarının tanıtımı amacıyla uluslararası sergiler düzenlenmeye başlanmıştı. 1851 yılında böyle bir sergi, ilk kez Londra'da açıldı. Osmanlı Devleti bu sergiye el işleri ve tarım ürünleriyle katıldı ve büyük ilgi topladı. Bunlardan bir kısmı, sergi sonlarında kurulan komisyonlarca ödüle değer bulundu. 1855 yılında, Paris'te açılan sergiye ilgi daha da büyük oldu. Bu sergiden de içlerinde kuru üzümüyle İzmir, inciriyle Aydın'ın da yer aldığı pek çok ödül kazanıldı. 1862 yılında da Londra'da ikinci kez düzenlenen uluslararası sergiye, Osmanlı Devleti yine çoğunluğu hammadde ya da yarı işlenmiş ürünlerin oluşturduğu mallarla katıldı ve çeşitli ödüller kazandı. Bunlar arasında sergiye, İzmir'den katılan üreticiler de vardı. İzmir'den üzüm ve incir çeşitleriyle P. Giudici, palamutla Malini Ağa ve bazı sanayi bitkileriyle Sidney Maltass madalya aldı. ${ }^{27}$

28 Şubat 1863 tarihinde İstanbul'da gerçekleştirilen ilk sergi [tarım sergisi], Sultanahmet

\footnotetext{
24 Osmanh Ziraat ve Ticaret Gazetesi, 23 Nisan 1907.

25 M. 1307 Salname-i Vilayet-i Aydnn, s. 697.

26 M. 1307 Salname-i Vilayet-i Aydnn, s. 711.

27 Abdullah Martal, Değişim Sürecinde İzmir'de Sanayileşme, Dokuz Eylül Yay., İzmir, 1999, s. 29-30.
} 
Meydanı'nda yapılan sergi binasında açıldı. Yerli ve yabancı mahsullerle eşyanın sergilendiği bu sergi, on üç kısma ayrıldı. Sergi açıldıktan bir ay sonra, ayrıca ziraat aletleri ve makineleri sergilemek için ayrı bir daire daha kuruldu. ${ }^{28}$ Sergide teşhir edilen hububat içinde, buğdaya ayrı bir önem verildi. Bu hububattan elde edilen unlarla, onları öğütmek için kullanılan değirmen ve ziraat makinelerine ait planlar vardı. Buğday temizleme makineleri de sergide çok dikkat çekti. Özellikle Bulgaristan'da, bu makinelerin üretimiyle ün yapmış firmalar sergide büyük takdir gördü. Buğdayları temizlemek için kullanılan en elverişli makine örneği olarak, Vachon temizleme makinesi adıyla H. Michel tarafından teşhir edilen bu makinenin, buğdayı mükemmel bir şekilde temizlediğine ilişkin örnekler sunuldu. Bu makinenin Osmanlı İmparatorluğu çiftçileri arasında yayılması halinde, buğdayın her türlü yabancı maddeden temizlenmiş olacağı ve buğday mahsulünün çok daha yüksek fiyatlarla satılabileceği anlatıldı. Sergide İzmir'i temsil eden iki tütün numunesi, Sarayaltı'dan ve Manisa'nın Kürsen köyünden verildi. Yaprakları orta büyüklükte, oldukça güzel renkte ve birbirlerine sicimle tutturulmuşlardı ve bu haliyle Yanya ve Sürmene'nin bazı tütünlerine de uygulanabileceğine ilişkin düşünceler ortaya çıktı. ${ }^{29}$

Osmanlıların ilk tecrübesi olan bu serginin ardından, Dünya da buna benzer sergiler yakından takip edilir hale geldi. Osmanlı Devleti 1872 yılındaki Viyana sergisine, 1874 yılında da Kaliforniya sergilerine katıldı. ${ }^{30}$ 1900'lerin başında Amerika'daki Sen Luis sergisi, İzmir basını tarafından ayrıntılı bir şekilde halka duyuruldu. Dünyadaki gelişmelerden uzak olmayan tavrı açısından İzmir basını bu sergi hakkında değerlendirmelerde bulunurken, Osmanlı ülkesiyle Avrupa ve Amerika arasında kıyaslamalar yapmaktaydı. ${ }^{31}$ Amerika, Sanayi ve Madencilikte büyük yatırımlar gerçekleştirmiş, 1870 yılında 2,786 milyon franklık ihracat değeri, 1902 tarihinde 8,021 franka ulaşmıştı. Önceki ihracat kalemlerinden farklı olarak sanayi ürünlerinin ihracatına ağırlık veren Amerika, Avrupa için hiç de küçümsenmeyecek bir rakip olarak hızla gelişti. Ziraatta ileri gitmeleri, bağcılığa büyük önem vermeleri ve büyük miktarlarda şarap üretimiyle uğraşması Amerikan

\footnotetext{
28 TZTB, age, s. 148.

29 TZTB, age, s. 161.

30 Abdullah Martal, age, s. 30-31

31 İzmir basını XIX. yüzyılın ortalarından itibaren tarımsal üretimin artırılmasına ilişkin büyük çabalar sarf etmeye başladı. Bunu gazete sütunlarına taşıyarak her şeyin hükümetten beklenmemesi gerektiğini, basının da icraatlar yapmaya hazır olduğunu belirten yazıların daha sık görülmesi izledi. Bir gazete yazısında şunlar yazılmaktaydı: “... Biz evvela köylülerimizi uyandıralım. Bunun için uğraşalım, sonra da icraatı hükümet-i seniyyeden bekleyelim...” Ahenk, 2 Kanunusani 1901. Tarım konusunda çok bilgili olmadıkları halde, iç bölgelerdeki köylüler Avrupa'nın zirai üretim yöntemlerine ilişkin konulara çok da habersiz değillerdi; köylüler, yavaş yavaş, eski çalışma alışkanlıklarından vazgeçmekte ve sık sık yeni ve daha kazançlı yöntemler denemekteydiler. Charles Issawi, The Economic History of Turkey [1800-1914], The University of Chicago Pres, London, 1980, s. 229.
} 
ekonomisini büyütmüştü. ${ }^{32}$ Bu yüzden, 1900'lü yılların başında üzüm ve şarap satın alımında Amerika'nın Almanya, İngiltere gibi ülkelerden sonra gelmesi hiç de şaşırtıcı değildir.

Osmanlı hükümetinin ilk büyük ve kapsamlı sergisinin yanı sıra yurtdışındaki sergiler, vilayetlerde gerçekleşen küçük çaptaki sergiler için birer örnek oluşturdu ve yerel ürünlerin durumu hakkında bir çeşit keşifte bulunulmasına imkân verdi. Buna ilişkin, 7 Eylül 1907 tarihinde İzmir'de bir üzüm müsabaka sergisi düzenlendi. Tüm üzüm üreticilerine açık olan bu sergide nefaset noktayı nazarınca tedkikat icra olunarak ve bu surette renk, irilik, körpelik gibi hususlar gözetilerek çekirdeksiz üzüm için birincilik kazanan üzüm sahibine beş yüz [kuruş], razakı için de birinciye bin, ikinciye beş yüz kuruş ödül verildi. Yapılan yarışmanın çekirdeksiz üzüm kısmının birinciliğini -Hacı Atenas, Konstanti, Hacı Yorgi adında- üç Rum paylaştı. ${ }^{33}$ Benzer sergi ve yarışmalar, XX. yüzyılın başlarında periyodik olarak her yıl tekrarlanmaya devam etti. Ziraat ve sanayinin terakkisi için [Aydın] Vilayet dâhilinde dahi mahsulat ve mamulat-ı dâhiliye sergilerinin masrafları dönemin Aydın Valisi Kamil Paşa'nın yazışmalarından anlaşıldığına göre bizzat hükümet tarafından karşılandı. ${ }^{34}$

\section{Íki Dünya Arasında Değișen ve Büyưyen Bir Ticaret Kenti: İzmir}

XIX. yüzyılın ortalarında, İzmir ve çevresine ilişkin değerlendirmelerde bulunan pek çok yazar veya seyyah, İzmir'i besleyen yakın art alanı olarak Gediz ve Menderes havzalarına işaret etmektedir. Örneğin, 1850'lerde İzmir ve çevresinde seyahat eden Rolleston'un ifadesine göre, "İzmir'e birkaç saatlik ulaşım mesafesinde olan bir-iki ovayla şehrin kendisinin sınırında bulunan ova, tarımsal üretim yapıldığı ölçüde her çeşit ürünü sağlamaktaydl." ${ }^{35}$ Döneme ilişkin ticaret ve endüstri kitaplarında da İzmir'in yakın art alanı olarak Gediz, Küçük ve Büyük Menderes vadileri gösterilmektedir. Aynı zamanda İzmir'in hinterlandında, tarımın ticarileşen ürünlerinin bu havzalardan İzmir limanına gelerek ihracat değerlerini oluşturduğu üzerinde durulur. ${ }^{36}$

XIX. yüzyılda sanayileşen Avrupa ülkeleri, iktisadi örgütlenmeyle ekonomilerinde büyük dönüşüm ve büyüme yaşadı. Bu dönüşüm ve büyümenin en önemli etkenlerinden biri, tarımsal ürün talebinde görüldü. Bu bağlamda İzmir ve yakın art alanı, tarımsal üretim ve ihracı bakımından batılı ülkelerin ihtiyaçlarına cevap veren cazip bir bölge olarak, Batı

32 Ahenk, 28 Kanunuevvel 1904.

33 Ahenk, 2 Teşrinievvel 1907.

34 B.O.A., Y.A. HUS., 456/4 [1904].

35 George Rolleston, İzmir 1856, Çev. Uygur Kocabaşoğlu, İzmir, 2010, s. 22.

36 G. Bie Ravndal, Turkey-A Commercial And Industrial Handbook, Washington, 1926, s. 79. 
Avrupa temelli dünya ekonomisinin etki alanına girdi. İzmir ve hinterlandında, Avrupa'nın tarımsal ürün talebinin artmasına bağlı olarak büyük bir ekonomik büyüme ve değişim yaşandı. Pamuk, meyan kökü, tütün, üzüm, incir, zeytinyağı, palamut fazlaca talep edilen ürünler arasında yer alıyordu. Patates gibi yeni ürünler, bölge tarımında önemli bir rol oynamaya başladı. Bu değişim, Batı Anadolu'da daha önce mevcut olamayan bazı yapısal ve kurumsal faaliyetleri de beraberinde getirdi. Bu değişim sürecinin temelinde, 1840'lardan itibaren serbest ticaret anlaşmalarının getirdiği hükümlerden ve Tanzimat Dönemi politikalarından kaynaklanan gelişmeler söz konusuydu. 1838 yılında, Balta Limanı Ticaret Antlaşması'yla neredeyse tamamı tarımsal ürünlerden oluşan Osmanlı ihracatı üzerindeki yasaklama ve sınırlamaların yanı sıra karmaşık bir yapı gösteren ve esasen her malın üretildiği bölgede tüketilmesi amacına [iaşecilik/provizyonizm] yönelik olan iç gümrükler kaldırıldı; yabancı tüccarlara Osmanlı ülkesinde yetiştirilen ya da işlenen her türlü ürünü satın alma hakkı tanındı; vergi ve gümrük kolaylıkları getirildi. Öte yandan Tanzimat'la birlikte, devletin tarıma yönelik bilinçli politikaları görüldü. Öncelikle tarımı geliştirmek için politikalar oluşturacak ve uygulayacak bir tarımsal bürokrasi kuruldu. Tarımsal üretimin artırılması, çeşitlendirilmesi ve tarımsal üretim araçlarının ve yöntemlerinin modernleştirilmesi hedeflendi. Yüzyıl boyunca, üreticilerin tarımsal kredi taleplerinin karşılanması amacıyla resmi kredi kurumlarının oluşturulması, üreticilerin teorik ve pratik bilgi edinmelerini sağlayacak eğitim kurumlarının ve model çiftliklerin kurulması, atıl toprakların ve tohum, bitki ve hayvan ırklarının ıslahına çalışılması, öşür muafiyetleri ve çeşitli yarışmalarla üretime teşvik sağlanması, tarımda yenilikleri yaygınlaştırmak için tarımsal araç gereçlere gümrük muafiyeti tanınması, devlet tekellerinin kaldırılması gibi politikalar izlendi. Bunların yanı sıra Osmanlı İmparatorluğu'nda özel sermaye birikimine en büyük engeli oluşturan müsadere uygulaması 1840 tarihli Ceza Kanunu ile suç sayıldı. ${ }^{37}$ Tımar sisteminin kaldırılmasından sonra özel mülkiyette yasal düzenlemelere gidildi, 1847 düzenlemeleriyle mülk sahiplerine tapuları verildi, 1858 yılındaysa kapsamlı bir Arazi Kanunnamesi hazırlandı. ${ }^{38}$ Bu kanunnameyle toprakta küçük köylü mülkiyeti, olası mal varlığının büyümemesi için açık sınırlamalar getirilerek fillen tanındı. 1867 yılında büyük bir ödün vererek, Bab-ı Ali yabancılara Osmanlı İmparatorluğu'nda taşınmaz mal edinme hakkı verdi. ${ }^{39}$ Bu yasanın çıkmasından çok önce İngilizler, İzmir ve hinterlandında az da olsa toprak satın almışlardı. Yabancıların, içerilerde satın aldıkları topraklar hızla genişledi ve 1860 yılında -yasanın çıkmasından yedi yıl

37 Murat Baskıcı, "Osmanlı Tarımında Makineleşme: 1874-1914”, Ankara Üniversitesi Siyasal Bilgiler Fakültesi Dergisi, 58 [1], Ocak-Mart 2003, s. 31-32.

38 Saadet Tekin, Tanzimat'tan Cumhuriyet'e Nazilli, D.E.Ü. A.I.I.I.T. Enstitüsü, Yayınlanmamış Doktora Tezi, İzmir, 1997, s. 102.

39 Reşat Kasaba, Osmanh İmparatorluğu ve Dünya Ekonomisi, Belge Yay., İstanbul, 1993, s. 48. 
önce- İngiliz konsolosu, büyükelçi Sir Henry Bulwer'e, bölgenin genel durumunun gün geçtikçe iyileşmekte olduğunu ama bu iyileşmeden yararlananların aslında Türkleri soyup soğana çeviren Hıristiyanların olup, ‘Gülhane Hatt-ı Şerifi'nin [Padişah Yazısı] öngördüğü reformlarla beraber Hıristiyanların tarımla ilgilenmeye başladıklarını, askerden dönen Türklerin köy ve kentlerini tanınmayacak kadar değişmiş bulmaya başladıklarını; tarlalarını işlemek isteyen Türklerin, hemen Hıristiyan bir tefecinin pençesine düşerek eninde sonunda toprağını satmak zorunda bırakıldığını içeren, ilginç raporu yollamak zorunluluğunu duyuyordu. ${ }^{40}$

1858 Arazi Kanunu, tapu senedini muhakkak toprağı gerçekten ekip biçen kişinin alacağına dair açıkça bir şey belirtmiyordu. Kanunun 3. maddesi, arazinin sahibini yani araziyi ekip biçme hakkına sahip olan kişinin tapuyu alacağını belirtiyordu. 78. maddeyse, araziye sahip olan ve toprağı on yıl boyunca ekip biçen kişinin harç ödemeksizin, tapu senedi alabileceğini öngörüyordu. Arazinin sahibiyle, ekip biçen kişi arasındaki karışıklığa, hükümetin sahip oldukları eski belgelerle taleplerini destekleyenlere, tapu verilmesine müsaade etme kararı da eklendi. Küçük üreticiye sağlanan bu koruma, 116. maddeyle zayıflatıldı. Kanun, miri toprakların borç ödemesi için satışına ancak; "borç verenin, araziyi satma niyetinden borçluyu haberdar etmesi" koşuluna bağlı olarak izin veriyordu. Arazilerin, küçük üreticilerden büyük üreticilere geçişi, üreticilerin yerel ayandan ve tefecilerden sıklıkla yüksek faizli kredi almalarıyla arttı. Ardı ardına gelen kötü hasat, genelde üreticilerin fakirleşmesi, arazilerin satılması ve bunların borç verenlerin eline geçmesiyle sonuçlandı. Birçok bölgede en iyi topraklar genellikle ayanın, tefecilerin ve kentli tüccarların elindeydi. Bu eğilim, muhtemelen üreticilerin ihracat pazarına katıldığ yerlerden biri olan İzmir ve çevresinde daha da gelişti. Dahası, toprağın faal olarak işlendiği büyük toprak sahipliği daha çok ticari tarım bölgelerinde ortaya çıkıyordu. Pazara yönelmenin muhtemel bir sonucu da bilhassa pamuk, üzüm ve incir gibi yoğun emek gerektiren ürün bölgelerinde küçük çiftçinin toprağını istimlak etme ve onu ücretli emekçi konumuna düşürme eğilimiydi. ${ }^{41}$

Tarımda ticarileşmenin öncüsü kabul edilen Batı Anadolu, ${ }^{42}$ XIX. yüzyıl boyunca

40 Orhan Kurmuş, Emperyalizmin Türkive’ye Girişi, Savaş Yay., Ankara, 1982, s. 78.

41 Donald Quataert, age, s. 61-62.

42 XIX. yüzyılda pazar için üretim Anadolu'da giderek daha fazla hâkim olmaya başlamasıyla birlikte, Anadolu tarımı XIX. yüzyılda hızla ticarileşmeye başlamıştı. Yalnızca tarımsal üretimde genel bir artış değil, pazar için üretilen ticari ürünlerde de önemli bir artış yaşanmaktaydı. Geniş bilgi için bkz. Tosun Arıcanlı, "XIX. Yüzyllda Anadolu'da Mülkiyet, Toprak ve Emek", Osmanlı'da Toprak Mülkiyeti ve Ticari Tarm, [haz.: Çağlar Keyder- Faruk Tabak], İstanbul, Tarih Vakfi Yurt Yay., 1998, s. 132-136 ve ayrıca bkz. Faruk Tabak, "Bereketli Hilal'in Batısında Tarımsal Dalgalanmalar ve Emeğin Kontrolü", Osmanli'da Toprak Mülkiyeti ve Ticari Tarm, [Editörler: Çağlar Keyder-Faruk Tabak], Çev., Zeynep Altok, İstanbul, 1998, s. 158. 
Avrupa'yla, Osmanlı Devleti arasında iktisadi yapıda organik bir değişime uğradı. Bu yüzden sadece tarımsal üretimin artırılmasına yönelik değil, aynı zamanda tarımsal üretimin çeşitlendirilmesine yönelik çabaların da sergilendiği bir bölge haline geldi. Batı Anadolu'da kırsal kesime yayılmış bulunan yüzlerce üretim birimi, bu şekilde bir ekonomik ağla birleştirildi ve iç ve dış pazarlardaki dürtülere toplu halde karşıllı verecek duruma hazır hale getirildi. ${ }^{43}$

İzmir bu yapısal dönüşümde, Osmanlı devletinde hemen hemen her dönemde olduğu gibi hammadde ihraç eden ana liman özelliğini korudu. İzmir Limanı çok çeşitli ve büyük kar getiren tarımsal ürünler yetiştiren art alanının iskelesiydi. ${ }^{44}$ Hinterlant da bulunan toprakların, hammadde kaynakları açısından verimli olması, bu bölgede demiryolunun yapılmasına ve yabancı sermaye sahiplerinin toprak satın almalarında önemli bir etken oldu. ${ }^{45}$ İngilizlerin toprak alma kararlarını etkileyen öğeler arasında, toprak fiyatlarının dönüm başına bir veya bir buçuk sterlin gibi çok düşük olmasının yanı sıra, tarlaları demiryoluna yakın yerlerde bulunan bazı köylülerin bu yeni icat karşısında çok büyük bir önyargı ve düşmanlıkla topraklarını bedava denecek kadar ucuz fiyata satmak istemelerinin de etkili olduğu görülmekteydi. ${ }^{46}$ Yetiştirilen mahsullerdeki çeşitlilik, Batı Anadolu bölgesi ziraatının başlıca coğrafi karakterlerinden biriydi. Sıcak, mutedil, soğuk iklim kuşaklarında ziraatı yapılan mahsullerden pek çoğu, Batı Anadolu bölgesi içinde yetişmekteydi. Bunlar, bölgenin birçok kesimlerinde yan yana yetiştirilebildiği gibi, birbirinin arasında yahut bir sene birbirinin, diğer seneyse diğerinin ziraatı yapılmakta ve mahsul alınmaktaydı. ${ }^{47}$ Tüm bu faktörler, öncelikle İngilizler olmak üzere Avrupalı girişimcilerin ellerinde biriken tüccar sermayesi yardımıyla, bölgenin pazar için üretim yapan bir nitelik kazandırılmasında ve ayrıca bölge tarımının kapitalistleştirilmesinde önemli bir rol oynadı. Dolayısıyla, İngilizlerin toprak satın almaları, 1867 yasasından sonra iyice hız kazandı. ${ }^{48} 1879$ yılında, Osmanlı Devleti arazi üzerinde daha fazla denetim sağlama

43 Reşat Kasaba, Osmanl Imparatorluğu ve Dünya Ekonomisi, age, s. 59.

44 Besim Darkot, "Aydın”, İslam Ansiklopedisi, II, İstanbul, 1961, s. 61.

45 Bülent Varlık, XIX. Yüzynlda Emperyalizmin Batı Anadolu'da Yaynlması, Ankara, 1976, s. 45.

46 Orhan Kurmuş, age, s. 79.

47 Süha Göney, Büyük Menderes Bölgesi, İstanbul Üniversitesi Yay., İstanbul, 1982, s. 246 ve 394. "Esas para getiren ürünlerin hasadı Temmuz ve Aralık ayları arasında birbirini kesintisiz izliyordu. Bu takvim, bir köylünün ya da bir hanenin bir tarlaya veya bir ürünle işlerini bitirip hemen ötekine geçmelerine izin veriyordu. Şubat-Mart ayı arası yoz otlar ayıklanır, Nisan-Temmuz ayları arası tütün yetiştiriciliğine ardından kuru üzüm ve incire büyük emek verilirdi." İzmir ve hinterlandındaki tarımsal üretim ve hasatıyla ilgili geniş bilgi için bkz. Dido Sotiriyu, Benden Selam Söyle Anadolu’ya, Çev., Atilla Tokatlı, 10. Baskı, Alan Yay., İstanbul, 1994, s.15, ve ayrıca bkz. Reşat Kasaba, "Batı Anadolu'da Göçer İşçiler 1750-1850”, Dünya, Imparatorluk ve Toplum-Osmanl Tazllar, İstanbul, 2005, s. 30.

48 Orhan Kurmuş, age, s. 79. 
çabalarıyla çelişen bir adım atarak, 1875-1881 yıllarındaki ağır mali kriz sırasında, şiddetle nakde ihtiyacı olduğundan ve bu yüzden gelirleri artırmak amacıyla hazineye, devlet arazilerini özel mülke çevrilmek üzere özel şahıslara satması için izin verdi. ${ }^{49} \mathrm{Bu}$ durumdan yararlanan diğer ülkelerin tüccarları da toprak satın alımlarını artırdı. Örneğin, İsveç onursal konsolosu ve bir Hollanda şirketinin sahibi olan Charles Van Lennep, Aydın ili yakınlarında büyükçe bir çiftlik satın alma fırsatını kaçırmadı.$^{50}$ Osmanlı ekonomik yapısının temeli sayılan toprak üzerindeki bu tür hukuki değişikliklere gidilmesi, toprağa bağlı olan diğer kurumlarda da hızla değişim sürecini başlattı. Bu bağlamda İzmir ve çevresi, Tanzimat'la ticaret serbestliğinin sağlanıp, toprakta özel mülkiyete öncelik tanımasından sonra özel teşebbüsün hareket ve yatırım alanlarını genişletmesinin sonuçlarının yakından izlendiği bir bölge oldu. Yabancı sermaye yatırımları İzmir ve hinterlandında genişledikçe, devlet pazar üzerindeki kontrolünü yabancı sermayeyle paylaşmaya başladı. İthalat ve ihracat işleriyle yetinmeyip, toprak satın alarak İzmir ve çevresinde çiftçiliğe başlayan İngiliz işadamları bu şekilde üretime katılarak üretimi teşvik etti. 1858 Arazi Kanunnamesi'nden sonra, İzmir ve hinterlandında, ekilebilir arazinin pek çoğu kırk bir İngiliz tüccarının sahip olduğu mülkü durumundaydı..$^{51}$

Memalik-i Mahruse-i Şahane'de kesretle bulunan servet-i tabiyenin tevsi' istimali maksadıyla İngiliz sermayedarlarını celb için, ${ }^{52} 1867$ yasasından sonra yabancıların toprak satın alıp, İzmir ve çevresinde büyük çiftlik plantasyonları meydana getirme süreci hızlanmıştı. Bu konuda en önemli gelişmeler, Batı Anadolu'da görüldü. Özellikle İngiliz şahıs ve şirketleri, 1857-1892 arasında İzmir, Kuşadası, Aydın, Tire, Bornova, Buca, Nazilli, Ayasuluğ ve Bergama gibi bölgelerde arazi satın alarak pamuk plantasyonları ve üzüm bağları kurdu. ${ }^{53} 1857$ ve 1892 yılları arasında İngilizler, İzmir ve hinterlandında yer alan Aydın'dan on iki bin dönüm [G. Meredith], Nazilli'den otuz altı bin sekiz yüz dönüm [Asia Minor Cotton Company], Aydın'dan altı bin dönüm [J. Aldrich], Ayasuluğ'dan beş bin yüz altmış dönüm [C. Gregoriades], Tire'den bin beş yüz elli altı dönüm [J. H. Hutchinson], Tire'den on sekiz bin sekiz yüz altmış sekiz dönüm [F. Whittall], Bornova'dan on altı bin üç yüz altmış [A. S. Perkins], Buca'dan seksen bin dönüm [A. Edwards], Bergama'dan seksen iki bin dönüm [Baltazzi] toprak satın almıştı. Bununla birlikte bazı bireyleri Fransız, bazı bireyleri de İngiliz uyruğunda olan Giraud ailesinin 1860'lı yıllarda Karaosmanoğulları'ndan satın

\footnotetext{
49 Donald Quataert, age., s. 61.

50 Orhan Kurmuş, age., s. 79.

51 Melih Gürsoy, Tarihi, Ekonomisi ve İnsanlarn ile Bizim İzmir'imiz, Metis Yay., İzmir, 1993, s. 94.

52 B.O.A., Y. PRK. TŞF. 5/78 [1898].

53 Murat Baskıcı, "Osmanlı Tarımında Makineleşme: 1874-1914”, Ankara Üniversitesi Siyasal Bilgiler Fakültesi Dergisi, 58 [1], Ocak-Mart 2003, s. 32.
} 
aldıkları geniş toprakların alanı veya değeri hiçbir resmi kayıtta görülmemekteydi. ${ }^{54}$ Satın aldıkları topraklarla birlikte, ilkel tarım teknolojisini de devralan İngilizlerden bazıları tarım yapılamayacağını ileri sürerek çiftlikten vazgeçtiklerini açıkladı. Bir bölümü de, kırsal kesimde hayatı felce uğratan eşkıyalık hareketlerinden son derece rahatsız olarak tarlalarını kısa zamanda satmak yoluna gitti. Bütün zorluklara karşı direnen çoğunluk, İngiliz toprak sahiplerinden, başlangıçta köylülerle ortakçılık veyaa yarıcılık anlaşmaları yapanlar olduğu gibi, daha da ileriye giderek köylüleri angaryaya koşmaya çalışanlar da oldu. Ortakçılık ve yarıcılık gibi geçiş döneminin belirtileri uzun süre devam etti. İngiliz tüccarları, toprak satın aldıktan sonra İzmir'deki işlerinin çokluğu yüzünden, tarımla gerektiği gibi ilgilenemediler. Bu nedenlerden dolayı, ortakçılık ve yarıcılık çok büyük çiftlikler ve İzmir'de büyük ticaret evleri olan İngilizlere ait geniş tarım arazilerinde devam etti. ${ }^{55}$ İngilizler ile köylüler arasında yapılan ortakçılık anlaşmaları zaman içinde çeşitli değişiklikler geçirdi. 1860'ların sonuna doğru İngilizler, köylülerden genel olarak ürünün yarısını talep ediyorlar ve köylülerin hangi ürünü yetiştireceklerine kendileri karar veriyorlardı. İzmir'in tarımsal ürünler ihraç eden bir liman olarak öneminin gitgide artması sonucu ortaklık anlaşmaları, İngilizlerin dileklerine uygun biçimde yapılmaya başlandı. ${ }^{56}$ XIX. yüzyılın sonlarında, İcar-ı Akar Nizamnamesi ile devlet küçük üretici kesimi, gelissip büyüyen toprak sermayesine karşı koruma altına almaya çalıştı. Dönemin ünlü ziraat muallimi Agop Zakaryan tarafından yazılan, Çiftlik İdaresi adlı eserde bu nizamname, maddeler halinde ayrıntılarıyla verilmiştir. Nizamnamenin ilk maddesine göre, “... gerek Dersaadet'te ve gerekse taşralarda her kim olur ise olsun hane ve dükkan ve arazi ve çiftlik gibi bir akarını icar edecek oldukda müstecir ile beynlerinde bir mukavelename tanzimine mecburdur." ${ }^{57}$ Devlet hazırladığı nizamnamenin satır aralarında, yapılacak

54 Cihan Duru-Kemal Turan- Abdurrahman Öngeoğlu, Atatürk Dönemi Maliye Politikası, 1. Kitap, TISA Yay., Ankara, 1982, s. 124 ve ayrıca bkz. Orhan Kurmuş, age., s. 80. Batı Anadolu tarımını harekete geçiren etkileşim belirli bir toprak mülkiyeti hiyerarşisine dayanıyordu. Toprak genişliğindeki farklılık, esas olarak çok büyük malikânelerle geçimlik tarlalar arasında değil, orta büyüklükteki tarlalarla küçük tarlalar arsındaydı. XIX. yüzyılın ortalarına doğru bu fark giderek belirginleşmişti. 1850'lerde büyük şehirleri çevreleyen bahçeler ve çiftliklerle kırsal kesime dağılmış olanlar arasındaki fark iyice açıldı. Bu topraklar pahalıydı ve entansif tarım yapılıyordu. İşgücü akışı büyük oranda bu bölgeye yönlenmiş ve bu bölge içinde yoğunlaşmıştı. Sonuçta, ticari tarımdan elde edilen karın çoğu bu iyi konumlanmış çiftçilerin elinde birikti. Geniş bilgi için lütfen bkz. Reşat Kasaba, "Batı Anadolu'da Göçer İşçiler 1750-1850", Dünya, Imparatorluk ve Toplum, İstanbul, 2005, s. 31.

55 Maltass, Abbott ve Whittall gibi büyük tüccarların toprak satın aldıktan sonra İmir'de işlerinin çokluğunu bahane ederek, eski toprak sahiplerinin köylülerle olan ortakçılık ve yarıcılık anlaşmalarını sürdürdükleri hakkında bilgiler vardır. Whittall'lerin İzmir'e gelişleri, ailesinin İzmir ve çevresindeki ekonomik faaliyetleri hakkında bkz., Edmund H. Giraud, Family Records-A Record Of The Origin And History Of The Giraund And Whittall Families Of Turkey, London, 1934, s. 63-78.

56 Orhan Kurmuş, age., s. 81-82.

57 Agop Zakaryan, Çiftlik İdaresi, İstanbul, 1897, s. 208-215. 
anlaşmada ileride çıkabilecek sorunlara karşı daha başından önlem almaya çalışmakta, anlaşma yapan tarafları ortakçılık ilişkilerinin sınırlarını ayrıntılı bir şekilde çizmeleri konusunda adeta uyarmaktaydl.

Yetiştirdiği mahsullerin Avrupa'da mükemmel pazarlar bulduğu Osmanlı ülkesinde, XIX. yüzyıl ortalarına gelindiğinde ulaşım imkânlarının hâla çok sınırlı olması, muntazam yolların bulunmaması, malların iskele şehirlerine kolay, rahat ve süratle sevkini güçleştirmekteydi. Bu yüzden, 1850'li yıllarda Anadolu ve Rumeli'de hinterlandın demiryollarıyla sahil şehirlerine bağlanması fikri rağbet gördü. ${ }^{58}$ Tanzimat Fermanı'yla yüzünü batıya dönen Osmanlı Devleti'nde demiryolları, batı medeniyetinin sembolü olarak görülmeye başlandı. Bunların ülke içinde yapılması konusunda başvuru da bulunan yabancı girişimcilere, bu yüzden cömertçe imtiyazlar verilmesinde bir sakınca görülmedi. ${ }^{59}$ İç bölgelerdeki tarımsal ürünleri İzmir'e daha kolay aktarmak, İzmir’e dış ülkelerden gelen malları daha geniş tüketici kitlesine ulaştırmak için, teknolojinin ulaşmış olduğu son nokta olan demiryollarının inşası, 1850'lerde gündeme geldi. İzmir'in hinterlandıyla ilişkisini kolaylaştıracak bir çalışmanın, kendileri için büyük bir kar sağlayacağını gören İngiliz tüccarları, İzmir'le Aydın arasında işleyecek bir demiryolunun inşası için Babıâli'ye başvurdular ve elçiliklerinin yardımıyla, 1856 yılının Eylül ayında istedikleri imtiyazı aldılar. ${ }^{60}$ İngiliz sermayedarlarının celbini teşvik için suhulutle icra ve istifadesi mümkün olan imtiyazdan biri olan ${ }^{61}$ İzmir-Aydın demiryolu, 1866 yılında trafiğe açıldı. İzmir-Kasaba demiryolu hattının imtiyazı yine İngilizler tarafından, 1863 yılında alınarak Afyon ve Alaşehir'e kadar uzatıldı ve 1894 yılında, Fransızlara satılan İzmir-Kasaba demiryolu hattının uzunluğu şubeleriyle beraber toplam, beş yüz on altı kilometreye kadar ulaştı. ${ }^{62}$ İngilizler, Büyük Menderes havzasında inşa ettikleri demiryoluyla bölgedeki tüm taşımacılığı, dolayısıyla da üretimi kontrol edebilmeyi hesaplamışlardı. İzmir'in hinterlandında, Büyük Menderes havzası kadar önemli bir havza daha vardı: Gediz Havzası. Gediz Nehri'nin kıyılarında, bugün olduğu gibi o günlerde de dünyanın en kaliteli çekirdeksiz üzümleri ve deri sanayide kullanılan palamut üretiliyordu. Bu nedenle İzmir'den başlayarak, o zamanlar adı 'Kasaba' olan Turgutlu’ya, Manisa üzerinden ulaşacak, bir demiryolu hattı planlandı. Batı Anadolu'da yeni bir güç sağlamak isteyen Fransızların, bu hatta

\footnotetext{
58 Mübahat Kütükoğlu, "Tanzimat Devrinde Yabancıların İktisadi Faaliyetleri”, 150. Milında Tanzimat, [haz. Hakkı Dursun Yıldız], TTK Yay., Ankara, 1992, s. 124.

59 Mehmet Özdemir, Mütareke ve Kurtuluş Savaşı Başlangı̨̧ Dönemlerinde Türk Demiryollarn-Yapısal Ekonomik Sorunlar [1918- 1920], Ankara 1998, s. 1-2.

60 Geniş bilgi için lütfen bkz. Cihan Özgün, Bereketli Topraklarda Üretmek ve Paylaşmak- İzmir ve Çevresinde Ticari Tarm [1844-1914], İzmir Büyükşehir Belediyesi Yay., İzmir, 2014, s. 43.

61 B.O.A., Y.PRK. TŞF. 5/78, 1898.

62 İzmir Ticaret Odası Tarihi: XIX Yüzynldan XXI. Yüzynla, İzmir, 2002, s. 21.
} 
göz dikmeleri sonucu İngilizlerle aralarında büyük bir mücadele yaşandı. İngiltere, Gediz hattının demiryolu haklarını aldıktan sonra, bölgedeki Fransız egemenliğini tamamen ortadan kaldıracağını hesap etti ve sonuçta kazananlar yine İngilizler oldu. Fransızlardan önce davranıp, 4 Temmuz 1863 tarihinde, İzmir-Kasaba Temdidi Demiryolu Hattı'nın imtiyazını, Bab-ı Ali'den almayı başardı. ${ }^{63}$ Edward Price adlı bir İngiliz girişimcinin adına verilen bu imtiyaz, Batı Anadolu'daki ikinci demiryolu hattının kurulması iznini de taşıyordu. Çünkü ‘Kasaba' [Turgutlu] ilçesi, Gediz Havzası'nın tarımsal ürünlerinin toplandığı en büyük yerleşim yeriydi. Bu hattın, ‘Kasaba’ya ulaşmaktan başka, iki önemli misyonu daha vardı. Kentin, Buca ve Seydiköy banliyölerinde, Aydın Demiryolu'nun ulaştığı başarıyı diğer iki önemli banliyö olan Karşıyaka ve Bornova'da da yakalamak. Fransızların bu alanda egemenlik sağlayabilme ideallerine kavuşmaları için, neredeyse otuz yıl beklemeleri gerekti. İngiliz Şirketi, 'Kasaba Hattı'nı, 27 Temmuz 1894 tarihinde Paris'te kurulan “İzmir-Kasaba ve Temdidi Demiryolu Şirketi”ne devretti. ${ }^{64}$

1894 yılında Fransa büyükelçisi Kambon, İngiltere'nin Mısır'da askeri ağırlığını artırmasındaki çabalarını, "işgali daimileştirmek maksadına dayandığına dair" beyanatlarda bulundu. Buna bağlı olarak, İzmir-Kasaba demiryolu imtiyazının İngilizlerden Fransızlara geçme sebebinin, İngilizlerin Mısır'ı işgaline dayandığına dair Standart gazetesi yoluyla yayınlar yapıldı. Dolayısıyla hükümet hem siyasal tepkinin bir sonucu olarak hem de siyasal bir denge unsuru sağlamak için, İzmir-Kasaba demiryolunun imtiyazını Fransızlara verdi. ${ }^{65}$ İzmir-Kasaba Demiryolu hattı şubelerinden, İzmir'den Turgutlu'ya kadar olan bölümüyle Manisa'yla, Soma-Bandırma ve Alaşehir-Uşak arasını Fransızlar inşa etti. ${ }^{66}$

İzmir ve hinterlandına demiryollarının yapımı, bölgede yabancı sermayeyi daha da güçlendirdi. Yabancı girişimciler, demiryolunun yapımından sonra bölgede tarım ve ticaretin gelişeceği ve kâr oranlarının yükseleceği düşüncesiyle büyük miktarda topraklar satın almaya başladı. ${ }^{67} \mathrm{Bu}$ da bölge tarımının, kapitalistleştirilmesinde önemli bir rol oynadı. ${ }^{68}$

63 Basmane Garı, 1863 yllında verilen imtiyaz gereğince inşa edildi ve İzmir-Kasaba [Turgutlu] demiryolu hattının başlangıç noktasını oluşturuyordu. Bu hattın açılmasıyla birlikte, İzmir'in Bornova, Bayraklı ve Karşıyaka yerleşimleri hızla büyüyen birer banliyö özelliğine kavuştu. Ayrıca hattın açılması, Gediz vadisinde üretilen malların, İzmir Limanı'na naklini sağlıyordu. Bu nedenle, Basmane çevresinde otellerin yoğunlaştığı bir kentsel doku oluştu. Bölgenin bu niteliği, fuar ve otogarın da etkisiyle güçlenerek kesin bir özellik haline geldi. Yaşar Ürük, İzmiri İzmir Yapan Adlar, İzmir Büyükşehir BelediyesiYay., İzmir, 2008, s. 49.

64 Nedim Atilla, İzmir Demiryollar, İzmir Büyükşehir Belediyesi Yay., İzmir, 2002, s. 107 ve 109.

65 B.O.A., Y.PRK. EŞA., 16/94, [1894].

66 Nedim Atilla, age., s. 109.

67 Gülçin Uzuntepe, Osmanl İmparatorluğunda İlk Demiryolu: İzmir-Aydın-Kasaba [Turgutlu] 1856-1897, Basılmamış Yüksek Lisans Tezi, Anadolu Üniversitesi, Sosyal Bilimler Enstitüsü, Eskişehir 2000, s. 97.

68 Orhan Kurmuş, age., s. 79. 
Demiryolu yapımıyla birikmiş servetler, toprağa yöneldi ve mevcut ekonomik sıkıntılar içinde bulunan köylülerin topraklarının tasarruflarını, bağ-bahçe ve evlerinin mülkiyetlerini, bazı direniş ve karşı koyma olaylarına rağmen ellerinden çıkarma eğilimi arttı. Demiryolları için istimlâk edilen araziler senet ve yazılı anlaşmalarla gerçekleşti. Ancak ilerleyen zamanlarda kumpanyayla arazi sahipleri arsında arazinin -türüne göre- kullanımı konusunda sorunlar ortaya çıktı. Yapılan mukaveleye göre, hiçbir ücret talep edilmeden demiryoluna terk edilmiş, boş durumda olan araziler istimlâk edilmişti. Kişilerin tasarrufundaki topraklarda da istimlâk ediliyordu. Nitekim hem vakıf yani, 'arazi-i mevkufe' hem de zahire, tahıl gibi ürünler getiren vakıf malları yani 'arazi- i müstagallat' ve hem de üzeri damla örtülü olan ev, han, dükkân gibi yerlerin olduğu, 'arazi-i müsakkafat' toprakları demiryolu kumpanyalarına geçti. Devlet kendi toprağı miri arazisini demiryolu hattı geçerken, 'meccanen terk ve tahsis ettiğinden' ücret talep etmedi. Ancak kumpanya tarafından istimlâk edilen arazilerin devlet tarafından planlı bir şekilde kontrol ve takibi de ihmal edilmedi. ${ }^{69}$

Demiryolunun, bölgedeki üretimi arttıracağı ve böylece İzmir ve hinterlandında daha çok vergi toplama imkânının ortaya çıkacağı düşüncesi hâkimdi. Tarımdan alınan verginin artmasının yanı sıra ticareti de geliştirecek olan demiryolu, hem ticaret gelirlerinin vergilendirilmesi hem de ithalat ve ihracattan alınan gümrük vergilerinin artması sonucu devlet hazinesine katkıda bulunacaktı. Demiryollarının inşasından sonra, İzmir'in büyük bir dış ticaret merkezi haline gelmesi, Osmanlı hükümetinin uzun vadeli hesaplarında haklı çıkardı. 1873-1877 yıllar arasında, İzmir gümrüklerinin yıllık geliri ortalama iki yüz otuz bin sterline ulaştı. Aydın vilayetinin bütün ihtiyaçları karşılandıktan sonra, devlet hazinesine transfer edilen miktar, yılda ortalama yedi yüz yetmiş bin sterlin dolayındaydı. 1910 yılına gelindiğinde bu miktar, bir milyon yedi yüz bin sterline kadar yükseldi. Bu rakamın, toplam devlet gelirinin \%15’i olduğu düşünülürse, demiryollarının ülkeye sağladığı kârın hayli şaşırtıcı boyutta olduğu anlaşılır. 1880-1900 yılları arasında demiryollarının geçtiği bölgelerde tarımsal vergiler \%114 arttı, buna karşılık demiryolu olmayan bölgelerdeki vergi artışı, \%63'de kaldı. ${ }^{70}$ Ülkede ticaretin serbestleşmesiyle, hızla arttığ görülen ithalata karşılık, demiryollarının etkisiyle ithalatı biraz gecikmeyle takip ederek, ihracat da yükseldi. 1865-1910 arsında ihracat 1.1 kat, ithalat 1.7 kat arttl.

İhracat değeri dalgalı bir seyir göstermekle beraber, ithalat değeri 1897 yılı hariç sürekli

69 "Demiryoluna terk olunacak mahaller meyanında bulunacak arazi-yi miriye ve tahsisat kabilinden arazi-yi mevkufe içün bedel-i öşr tahsis olunmayub ancak gerek hükümet-i seniyye namına gerek kumpanya namına kayd ve ferağ edilsün, evkaf-ı mahaliyeden olan yerlere bedel-i mukataa takdir olunarak kumpanya tarafindan tesviye olunmasi" istenmektedir. B.O.A., A. MKT. MHM., 102/54 [1891].

70 Orhan Kurmuş, age., s. 49-50. 
yükselmeye devam etti. 1865-1910 döneminde yedi yıl hariç ihracat ithalattan fazla olup, İzmir temelde bir ihracat limanı özelliğini korudu. ${ }^{71}$

Demiryollarının inşa edilmesiyle, İzmir'in hinterlandında yer alan Köşk'ün zeytinyağı ve meşe palamudu; Sultanhisar'ın meşhur portakalı, Atça'nın pamuğu, Ödemiş'in patatesi, kendiri ve tütünü, İzmir Limanı'na hızla nakledilmeye başladı. ${ }^{72}$ İhraç edilen tarımsal ürünlerin değeri ve üretimi de arttı. Demiryollarıyla daha önce önemsenmeyen yerleşimler, önem kazandı. Örneğin demiryolu gelinceye kadar, XVIII. ve XIX. yüzylllarda Cihanoğlu Ayan ailesinin topraklarının büyük bir kısmının bulunduğu, pamuk, zeytinyağı ve hububat üretimiyle ünlü olan Koçarlı'nın önemi azaldı çünkü buraya demiryolu hattı inşa edilmemişti; buna rağmen hattın ulaştığı İncirliova daha önemli bir merkez haline geldi. Yeni yerleşim alanları, tarımsal araziler üzerinde oluştu. Önceleri güvenlik nedeniyle tercih edilmeyen ovalarda, çukur alanlarda, vadilerde yeni köyler ve kasabalar kuruldu. Bu konuda en iyi örnek, Tepeköy'ün yanında kurulan ve demiryolunun gelmesiyle beraber ovada hızla büyüyen, Torbalı'dır. Demiryolunun gelmesiyle; Aydın, Çine, Muğla ve Milas'ın iskelesi haline geldi. Eskiden yağhane olarak çalışan işlikler, bir süre sonra büyük zeytinyağı fabrikalarına dönüştü. Demiryolları boyunca meyankökü ve pamuk temizleme fabrikaları kuruldu.

Sonuç olarak, tarımdan alınan vergiler demiryoluyla birlikte arttı, tarıma bağlı ticaretin de gelişmesiyle birlikte ithalat ve ihracattan alınan gümrük vergileri de devlet hazinesine büyük katkılar sağladı. ${ }^{73}$

71 Murat Baskıcı, age., s. 66; Avrupalılar için, hiç kuşkusuz Osmanlı Devleti hammadde ve pazar olma niteliği yanında jeopolitik bir önem de taşıyordu. Osmanlıların stratejik köşe noktaları mutlaka ele geçirilmesi gereken bir köprübaşı gibiydi. Nitekim, İngiltere Sefiri’nin İzmir-Aydın demiryolunun, Iğdır’a kadar uzatılması vaadinin yerine getirilmesine yönelik Osmanlı Devleti'ne başvurması bu şekilde, İngilizlerin Kafkaslara ve ötesine taşıracağı bir demiryoluyla Hindistan'1, Afganistan üzerinden bir ticari demir koridorla etkisi altına almak isteyişinin de en büyük kanıtı gibi görünmektedir. Aslında Osmanlı yöneticileri, İngiltere sefaretine Aydın Demiryolu'nun yüz kilometre daha uzatılması yönünde ki vaatlerini en kısa zamanda yerine getireceklerini belirtmişti. İngiltere Sefiri göreve geldi geleli bu vaat yerine getirilmediği için İngiltere hükümeti karşısında zor duruma düştüğünü bildiriyordu. İngiltere Sefiri böylesine ciddi ve uzun bir karar verme süresi gerektiren durum hakkında bir, iki güne kadar kesin bir cevap verilmesini ısrarla istiyor, cevabı derhal Londra'ya bildireceğini söylüyordu. Londra'da, Lordlar Kamarası'nda ve Parlamentosun'da bu vaadin yerine getirilmesi yönünde cereyan eden görüşmelerin olduğunu belirten İngiltere Sefiri, iki devlet arasında ki iyiliğin "şimdiye kadar devleteyn beynindeki münasabat hüsnünün takviyesine" yapacağı katkıyı da hatırlatmaktan geri kalmıyordu. Ancak en önemli ayrıntı ve ilgi çekici talebi, "diğer devletlere yapılan muamelenin aymısınn kendi devleti içinde yapılmasını" istemesinde kendini göstermişti. B.O.A., Y. MTV, 276/70, [1907].

72 Nedim Atilla, age., s. 84-86.

73 Geniş bilgi için bkz. Orhan Kurmuş, age., s. 50-56; Nedim Atilla, age., s. 64-68; Bilgin Çelik, Cumhuriyet Dönemi’nde Aydın’n Sosyo-Ekonomik, Kültürel Yapısı [1923-1950], Basılmamış Yüksek Lisans Tezi, D.E.Ü. A.İ.I.T. Enstitüsü, İzmir, 1996, s. 26; Engin Berber, "Yunan Kaynaklarında Kuşadası 18761923”, Geçmişten Geleceğe Kuşadası Sempozyumu [23-26 Şubat 2000], İzmir, 2001, s. 295-303; Tuncer Baykara, 


\section{Yüzyılın İkinci Yarısında İzmir’de Zeytin ve Zeytinyağı}

Zeytin ağacı sekiz-dokuz metre yüksekliğinde, Nisan-Haziran ayları arasında çiçek açan bir meyvedir. Osmanlı çiftçisi, zeytinlikleri her dört sene de bir gübreler ve her sene altlarının bellenerek sürülmesi işlemini uygulardı. ${ }^{74}$ Zeytin ağacına üçüncü veya dördüncü senesinde kabuk aşısı yapılmalıydı ${ }^{75}$ ve bu yöntem yabani zeytinler için de uygulanmalıydı. Zeytin ağaçlarını budamak, bir başka önemli etkinlikti. Bu uygulama, zeytin ürününün hasılatının artmasına yardımcı oluyordu. Zeytin ağacının ufak dalları üzerindeki danelerin yağı çok daha fazla olurdu. Zeytin ağaçlarında en çok görülen hastalık, 'karabalık' hastalığıydı. ${ }^{76}$ 'Karabalık' hastalığı şeftali, zeytin, portakal ve armut gibi meyve ağaçlarında görülen yosun cinsinden bir takım mantarlardan meydana gelmekte, bu hastalığa tutulan ağaçların yaprakları taş gibi sert bir hal almaktaydı. Hastalıkla mücadelede yöre halkı ağacın tepesinden başlayarak, göz taşı kullanırdı. ${ }^{77}$

İzmir ve çevresinde zeytin yetiştirilmesine tarihi tespit edilemeyecek kadar evvel başlanılmıştı. Tarihte yemeklik ve yağlık zeytinler beslenmede önemli olduğu kadar zeytinden elde edilen yağ aydınlatmada ve Rum ateşi gibi bazı yakıcı silahların hazırlanmasında da kullanıldı. ${ }^{78}$ Zeytin doğanın şifalı gücünden biri olarak halk arasında, halk hekimliğinde sıkça baş vurulan bir tarım ürünüydü. Aralıklı ateş gösteren hastalıklar, en akut durumlarda bile kininle kontrol altında tutuluyordu. Daha etkili bir yöntemse zeytin yapraklarını kaynatarak elde edilen özün -yaklaşık yarım litre kalana kadar kaynatılan yaklaşık bir litre su içinde yaklaşık otuz gram zeytin yaprağı belirli- bir değerde ateş düşürücü özelliğinden yararlanılmasıydı. ${ }^{79}$ Bunun yanında, küspesi gübre ve yakıt olarak kullanılmakta, kerestesi mobilyacılıkta değer taşımakta, sığır yemi olarak yapraklarından yararlanılmaktaydı. ${ }^{80}$ Osmanlı topraklarında, özellikle Akdeniz kıyılarında ve bu iklime

XIX. Yüzynlda Aydn Eyaleti, Mezuniyet Tezi, İstanbul Üniversitesi Edebiyat Fakültesi Tarih Bölümü, 19651966, s. 43-44.

74 Zeytin meyveleri, rüzgâra karşı direnemeyerek pek çok kereler dökülürlerdi. Bu yüzden fosforlu gübreler, meyveli ağaçlar için özellikle zeytin için çok önemlidir. Bu tür gübreler, zeytine kuvvet verirdi. Zeytin, dut, incir, badem, elma, kiraz, erik, şeftali gibi ağaçlara bir okka fevk fosforit, yarım okka flor potas, yarım okka da azotit sod veya kibritiyet amonyak uygulanırd.. N. Kiryako, Çifţ̧ilikte Terakki ve Kimyevi Gübreler, Ticaret ve Ziraat Nezareti, İstanbul, 1911, s. 32, 38 ve 40.

75 Her çeşit meyve ağaçlarında çok önemli bir uygulamadır. Özellikle fidanlarda en çok yapılan kabuk, kalem ve göz aşılarıdır. Hüseyin Kazım, Ziraat Albümü, Tanin Matbaası, İstanbul, 1914, s. 107.

76 Hüseyin Kazım, age., s. 107.

77 Osmanl Ziraat ve Ticaret Gazetesi, 1 Mays 1907.

78 Hüseyin Avni, “İzmir'den Aydın’a”, İktisadi Yürüyüs, yıl: 4, cilt. 9, sayı. 86, 16.07.1943, s. 11, 78, 79.

79 George Rolleston, age., s. 63.

80 Batı Anadolu'da yaygın olmasa da gübre kullanımı olmakla birlikte hayvan gübresinin yanında zeytin küspesinin de gübreleme de kullanıldığı görülmekteydi. Süha Göney, Age., s. 508-509; Zeytin için en 
benzeyen yerlerde bağ dikiminin Mart ayının sonuna doğru tamamlanması gerekirdi. Daha soğuk yerlerdeyse bağ dikimi, Mart ayının sonuna doğru başlardı. Bağların bellenmesi veya sabanla sürülmesi, bağlardan yüksek verim elde edilmesini sağladığı gibi bağlarda meydana gelen zararlı otları yok etmek için bağ kütüklerine zeytinyağıyla karıştırılmış gazhane zifti sürülürdü. Bu haliyle üzüm üretiminde zeytinyağının hiç beklenmedik bir yardımı da söz konusu olabilirdi. ${ }^{81}$

Tarımsal üretim konusunda, geleneksel yapısını sürdüren bölge köylüsü zeytinleri uzun sopalar yardımıyla düşürerek toplamaya çalışırdı. 0 yılın meyveleri toplanırken, dala vurulan her bir sopa darbesi, gelecek yılın filizlerini de bu yılın meyveleriyle birlikte düşürmekte, böylece bir yıllık ürün kaybı yaşanmaktaydı. ${ }^{82}$ Zeytin ağacının mahsulleri arasinda; Sisam veya Girit, Karazeytin, Akzeytin, Edremit, Çoban İsa, Domates, Midilli, Kekre, Memeli, Memecik, İrikara, Tekir, Yağ ve Kara, Gülümbe, Karaca, Çakır, Şakran, Yerlikara, Hurmayağ, Tohum, Devedişi, Tekke, Deli, Çilga, Azman, Yerliyeşil, Sarı, Düz, Edremit, Aydın, Boncuk gibi birçok zeytin çeşitleri sayılabilir. ${ }^{83}$

İzmir ve hinterlandı, öncelikle olarak sarayın ve başkentin ihtiyacını karşılayan iaşe kuşağındaydı. İzmir ve art alanı, birincil bir tahıl kaynağı değildi ama bölge sahasında yetişen başka ürünler özellikle eşsiz üzüm ve incirin, ayrıca zeytinyağı ve pirincin önemli müşterisi, kiler-i hümayundu. ${ }^{84}$

Hükümet tarımsal üretimin artırılması, dış ticarette tarım ürünlerinin önemli birer ihracat maddesi haline gelmesi için gösterdiği çabalardan birini de, zeytin üzerinde sarf etti. Tanzimat döneminde tarımı geliştirmek düşüncesiyle, çiftçilerin üretim alanlarını genişletmek, ticari değeri yüksek olan ürünlerin üretimini artırmak için bu ürünlere geçici vergi muafiyetleri sağlamak, üretimde modern araç kullanımını yaygınlaştırmak amacıyla yurt dışından getirtilecek araç ve gereçlerin gümrüksüz ithal edilmesi gibi politikalar uygulanmıştı. Bu politikaya bağlı olarak, 1850 yılında zeytinlik yetiştirenlere yirmi beş yıl, yabani zeytin ağaçlarını aşlayanlara yirmi yıl vergi muafiyeti getirildi. ${ }^{85}$ Yeniden yetiştirilen zeytinlikler hakkında, 27 Haziran 1862 tarihinde bir muafiyet nizamnamesi yayınlandı. Bu nizamnameye göre yeniden yetiştirilen zeytinlikler, ilk mahsul senelerinden itibaren üç yıl boyunca öşürden muaf tutuldu. Ayrıca, "iki senelikten beş

güzel azotlu gübre zeytin çekirdekleriydi. N. Kiryako, Çiftçilikte Terakki ve Kimyevi Gübreler, age., s. 40.

81 Osmanh Ziraat ve Ticaret Gazetesi, 13 Mart 1909.

82 Charles İssawi, age., s. 229.

83 TZTB, age., s. 42.

84 Daniel Goffman, Levanten Dünya ve İzmir, İstanbul, 1995, s. 28-29.

85 İsmail Yıldırım, agt., s. 315. 
seneliğe kadar aşılı olduğu halde gars olunanlar [dikili bulunanlar] gars olundukları tarihten itibaren on sene müddetle öşürden muaf olacaktı. Beş seneden ziyade aşıll olarak gars olunanlar, gars olundukları tarihten itibaren yedi sene müddetle öşürden muaf olacaktı. Bir kimse yeniden yetiştirip de nail-i muafiyet olduğu zeytinliği ahere satacak olduğu halde evvel muafiyeti dahi beraber satacaktı." ${ }^{86}$ Zeytin, XIX. yüzyılda vilayetin en verimli ve kazançlı ürünlerinden biri olarak İzmir'in özellikle iç kesimlerinde, Büyük Menderes havzasında yoğun olarak yetiştirildi. Büyük Menderes Nehri'nin sağ ve sol sahillerini çevreleyen arazinin düzlükleri, vadiyi çevreleyen dağların etek ve yamaçları, toprak ve iklim koşullarının da sağladığı imkânlarla birleşince, bu havzada zeytin tarımı büyük gelişme gösterdi. ${ }^{87}$ XIX. yüzyıl ortalarında, Büyük Menderes havzasının dışında elde edilen zeytinyağı kalın ve koyu renkli olması nedeniyle çok da talep edilmiyordu. ${ }^{88} 1840$ 'lı yılların başında Aydın Sancağı merkezinde, 11.477 kıyye zeytinyağı üretilmişti ve yağın 1 kıyyesi, kalitesine göre değişme göstermekte olup 4 kuruştan alıcı buldu. ${ }^{89}$ Küçük Menderes havzasının önemli bir ticaret kenti olan Tire'deyse, aynı tarihlerde yağın her kıyyesi 5 kuruş, 30 paraya alınıp satılmaktaydı. ${ }^{90}$ Bir okka zeytinyağı 1853-1854 yıllarında 5 kuruş, 18631864 yıllarında 7 kuruş 15 para, $1868-1869$ yılları arasında 11 kuruşa ve 1873 yılındaysa 12 kuruşa kadar düzenli bir artış seyri izledi. XX. yüzyılın başlarında, zeytinyağının fiyatı, 11 kuruş civarındaydı. ${ }^{91}$

1840'ların sonunda Karasi, Aydın, Sığla, Midilli, Ayvalık kazaları başta olmak üzere Batı Anadolu Bölgesi'nin büyük bir kısmının zeytinyağının alım satımıyla uğraşan, Baltacı Bazergan'ın sadece Sığla Sancağı'ndan 139.718 kantar, Aydın Sancağı'ndan 87.604 kantar zeytinyağı alımı yaptığı tespit edilmektedir. ${ }^{92}$ Baltacı Bazergan’ın, bölge zeytinyağını

\footnotetext{
86 “Zeytinlik Yetiştirenlerin Muafiyetine Dair Nizamname”, Düstur, T. 1, C. 2, [1862], s. 440.

87 Aydin İ Millı̆̆, 1967, s. 295.

88 Karl Von Scherzer, İzmir-1873, [çev. İlhan Pınar], İzmir Büyükşehir Belediyesi Kent Kitaplığı Yay., İzmir 2001, s. 69-70.
}

89 Cihan Özgün, age., s. 211.

90 Mehmet Başaran, Tanzimat'tan Cumhuriyet'e Tire, İzmir 2000, s. 163.

91 XIX. yüzylın ortalarından, XX. yüzyıl başlarına kadar olan süreçte İzmir ve çevresinde gözlenen bazı tarım ürünlerinin fiyatlarına ilişkin veriler şu kaynaklardan yararlanılarak derlenmiştir: Abdullah Martal, Değrşim Sürecinde İzmir, age., s. 238-239; Filiz Çolak, II. Meşrutivet'ten Cumhuriyete Batı Anadolu'da Üretim ve Dış Ticaret [1908-1923], DEÜ Aİ̈T. Enstitüsü, Basılmamış Doktora Tezi, İzmir, 2005, s. 118-121, Sabri Sürgevil, II. Meşrutiyet Döneminde İzmir, İzmir Büyükșehir Belediyesi Yay, İzmir 2009, s. 198-214; Karl Von Scherzer, age., s. 64-86; Charles İssawi, "Wages in Turkey [1850-1914]", Türkiye'nin Sosyal ve Ekonomik Tarihi, [ed.] H. İnalcık-O. Okyar, Ankara, 1980, s. 267-268; 1909-1910 yıllarında İzmir ve yakın hinterlandındaki bir kıyye zeytin yağının fiyatı Aydın'da 5.25 kuruş, Manisa'da 5.6 kuruş, İzmir'deyse 5.3 kuruş düzeyineydi. Bu rakamlarsa, Memalik-i Osmaniyenin 1330 Senesine Mahsus Ziraat Istatistiğidir; Ticaret ve Ziraat Nezareti İstatistik-i Umumiyesi, İstanbul, 1335 [Rumi], 1919 [miladi] Matbaa-i Osmaniye adlı eserlerden derlenmiştir. 92 BOA A. Cevdet Maliye, 22890 [1848]. 
alım ve satımının ne kadar sürdüğüne yönelik bir veriye sahip değiliz. Ancak 1850 yıllarda, İzmir'in hinterlandındaki vadilerde Agop gibi zeytinyağı aşarı toplayan bezirganlar, ${ }^{93}$ Sardunyalı zeytinyağı tüccarı Vikyadore Bortum, Avusturya tebasından Jozef Pensu gibi bizzat zeytinyağı toplayan tüccarların varlığını da tespit edebiliyoruz. Özellikle Pensu'nun, Bortum veya Baltazi'den en önemli farkı zeytinyağını bizzat toplamamasıdır. Bir Yahudi'yi aracı kılar ve kendisi İstanbul'da ikamet ederken, aynı zamanda tarımsal üretimde bulunan köylülerle borç-alacak ilişkisi kurar. Bortum, İzmir'in hinterlandındaki bir kısım bölgenin zeytinyağının Avrupa'ya ihraç edilmesinde, Kuşadası Limanı'nı kullanır. Bu durum, 1850'li yıllarda henüz demiryolları inşa edilmediği için ihraç kapısı olarak Kuşadası Limanı'nın önemini koruduğunu göstermesi ve bu iskelenin İzmir Limanı'na tercih edildiğini ortaya koyması açısından da önemlidir. ${ }^{94}$

XIX. yüzyılın ortalarında İzmir'in, hemen ardında bulunan bazı yerleşim yerlerinde yapılan resmi sayımlar hemen hemen bütün hanelerde en az bir zeytin ağacının olduğuna işaret etmektedir. Bu da, ev halkının kendi ihtiyacı olan sofralık zeytin ve zeytinyağını bu ağaçlardan karşıladığına yönelik bir 'ipucu' sayılabilir. İzmir'in hinterlandında bazı yerleşim yerlerinin incir, üzüm, pamuk, susam gibi ürünlerin ekilip dikilmesinde uzmanlaştığı gibi Bayındır, Tire, Kula gibi bazı yerleşim yerlerinde de zeytinciliğe diğer tarım ürünlerine nazaran biraz daha fazla önem verildiği, tarımsal etkinlikler içinde ön sıralarda geldiği de anlaşılmaktadır. Ayrıntılı bir inceleme, İzmir ve çevresinde incir, üzüm, zeytin gibi ürünlerle meyankökü, palamut, tütün ve pamuk gibi ürünlerin kabaca iki kategoriye toplanıp, bunların kendi aralarında rekabet ettiklerine ilişkin bir yoruma da fırsat verecek türdendir. Aslında bu türden yorumun ardında saklı olan temel sebebin bölgenin, Avrupa'nın taleplerine uygun şekilde ve Osmanlı hükümetinin denetiminde ticari tarım düzeninin hızla yerleşmesi ve bu yüzden sanayi bitkilerine yönelimin artmasıdır. Pamuk, tütün, susamın hasılat değerleri XIX. yüzyılın sonlarında dikkate değer ölçüde artarken hububat gibi geçimlik ürünlerin önemlerini korumasına rağmen, bunlardan sonra talep edilebilir konuma düşmesinin başka türlü açıklanması pek mümkün gözükmemektedir. Tütün, pamuk, üzüm gibi ürünlerin geçimlik değil, ticari ürün olduğu göz önünde bulundurulursa, bölgede geçimlik üründen ticari ürüne yönelişin var olduğu da anlaşllır. XIX. yüzyılın ortalarında İzmir ve çevresinde tarımsal ürünler çeşitlidir. Bunun bölgenin uYgun iklim koşulları, tarımsal kapasitenin yüksekliği ve uluslararası taleplerin henüz göz ardı edilebilir olmasından kaynaklandığı söylenebilir. Bu durumun XIX. yüzyılın sonlarında değiştiği, İzmir piyasası odaklı yeni bir ürün çeşitliliğinin oluştuğu, tek bir ürünün yetişmesinde uzmanlaşmanın yer yer söz konusu olmaya başladığı ancak bunun İzmir

93 BOA A. MKT. MHM 15/17 [1849].

94 BOA A. DVN. DVE 2/43 [1841]; BOA A. AMD 21/71 [1850]. 
ve art alanının tümü için genelleştirilemeyeceğini de eklemek gerekir. ${ }^{95}$

İzmir ve çevresinin ekonomik hayatında ticarete konu olan en önemli ürünlerden biri olan zeytin ve zeytinyağının 1850'li yıllarda durumuna ilişkin eldeki veriler, bu ürünün İzmir piyasasında afyon, üzüm ve şaraba olan talebin gerisinde olduğu yönündedir. Bunun en önemli nedeni olarak da, nakliye güçlükleri gösterilmektedir. ${ }^{96}$ Yüzyılın ortalarından, 1875'li yıllara kadar da ihracat payında diğer bazı tarım ürünlerine göre yüksek ihracat değerine ulaşamamıştır. ${ }^{97}$ Demiryollarının bölge ekonomisine gösterdiği en büyük faydanın ticari ulaşımda sağladığı 'sürat' olduğu düşünülürse, zeytin ürününün İzmir piyasalarında 1875'li yıllarından sonra artış göstermesi çok daha iyi anlaşılır.

1870'lerin başında hinterlanddan İzmir'e ihraç edilmek üzere ortalama, 75-80 kantar zeytinyağı gönderilmekteydi. Vilayette toplam olarak üretilen, 230-250 bin kantar zeytinyağının, yüz-yüz on bin kantarı iç piyasada tüketilmekte, geriye kalanın \%35'i Marsilya, \%30 Tiryeste'ye, \%20'si İngiltere'ye, \%15'i Kuzey Almanya'ya ihraç edilmekteydi. ${ }^{98}$ Art alanı, İzmir'e bağlayan demiryolunun yapımında sonra ticari önemini kaybetmesine bağlı olarak, Kuşadası'ndan ihraç edilen tarım ürünlerinde büyük düşüşler yaşandı. Kuşadası Limanı, demiryollarının inşasından sonra hinterlandından gelen ihracat ürünlerini İzmir Limanı'yla paylaşmaya başlaması sonucunda, 1893 yılından sonra Kuşadası'ndaki zeytinyağı ihracat değeri, 213.000 kg gibi düşük bir seviyede kaldı ve Marsilya, Londra ve Pire Limanlarına ihraç edildi. ${ }^{99}$

İzmir'in zengin zeytin alanlarının bulunduğu yerlerden biri olan Tire'de, 4-7 kilo zeytinden ortalama, 1 kilo yağ elde edilmekteydi. XIX. yüzyllın sonlarında da, Tire'nin zeytini İzmir'e gönderilmeye devam etti ve her kantar için altın akçe olarak, 6,5 kuruş masraf yapılmakta ve her kıyyesiyse 25 paraya satılmaktaydı. 1890-1891 yıllarında Tire'de, iki adet zeytinyağı fabrikası bulunmaktaydı. Buharla işletilmekte olan bu fabrikaların sahiplerinden biri, Hacı Ali Paşa ve diğeri de, Flemenkli Hefter'dir. 1908 yılındaysa fabrika sayısının altıya çıktığı tespit edilmektedir. Burada yıllık olarak, 25.000 kıyyeye yakın yağ çıkarıldığı bilinmektedir. İki tane sabunhane bulunmakta ve burada üretilen sabunlar içeride ve dışarıda satılmaktadır. Salnameler'de, İzmir'de zeytinyağı fabrika sayısının yedi veya sekiz adet olarak verildiğini de eklemek gerekir. ${ }^{100}$

95 Geniş bilgi için lütfen bkz. Cihan Özgün, age., s. 75- 81.

96 Nakliye güçlükleri zeytinin tuzlanmasını zorunlu kılarak ve böylelikle de yağın saflığını bozarak kaliteyi olumsuz olarak etkiler. George Rolleston, age., s. 73.8283

97 Cihan Özgün, age., s. 211.

98 Karl Von Scherzer, age., s. 70.

99 Cihan Özgün, age., s. 212.

100 Mehmet Başaran, age., s. 163. 
XIX. yüzyılın ikinci yarısında, İzmir'in başlıca ürünlerinin ihracat değerleri ve İzmir'in toplam ihracatı içindeki payları kuraklık, salgın hastalık veya dünya piyasasındaki dalgalanmalara göre şekillendi. ${ }^{101}$ Zeytin ürününden alınan mahsulün diğer ürünlere göre belirsizliği, bu ürünün büyük boyutlarda ticarileşmesini ya da en azından İzmir Limanı'ndan yapılan ihracat listelerinde en başlarda yer almasını engellemiş olmalıdır. Döneme ilişkin veriler bu doğrultudadır ve köylünün zeytin toplamasındaki yanlışlıkların alınan verimi düşürdüğü üzerinde yoğunlaşır. Aynı zamanda zeytin mahsulü, bir yıl az bir yıl fazla olmak üzere her yıl değişik miktarlarda alındığından, zeytin ve zeytinyağı üretim miktarı da, yıldan yıla değişmekteydi. Bu bakımdan zeytinyağı ihracatı, mahsulün durumuna göre, Osmanlı yönetimince ayarlanıyordu ve hükümetin iznine bağlıydı. ${ }^{102}$ XX. yüzyıl başlarında İzmir'in hinterlandında yer alan Aydın sancağında, '3.500.000 sak’ zeytin ağacı bulunmakta ve sözü geçen miktar ağaçlardan, 17.000.000 kıyye zeytinyağı elde edilmekteydi. ${ }^{103} 1907$ yılında sadece Nazilli'de 1.000 .000 kıyye zeytinyağı üretilmişti ki, Karacasu'da 1909 yılında üretilen yağ, Nazilli'nin 1/50 civarında, 20.000 kıyye dolaylarındaydı. ${ }^{104}$

1869-1881 yılları arasında, İzmir Limanı'ndan ihraç edilen zeytinyağı miktarı düzenli bir seyir izlememekteydi. 1869 yılında 16.840 ton, 1870 yılında 11.200 ton, 1871 yllında 6.210 ton, 1872 'de 2.550 ton, 1873 yllındaysa 280 ton zeytinyağı ihraç edildi. Her geçen yıl ihraç miktarı azalan zeytinyağı, 1874 yılında en düşük ihraç oranına düştü. Döneme ilişkin konsolosluk raporlarından, 1874 yılında İzmir'den sadece 45 ton zeytinyağının ihraç edildiği anlaşılmaktadır. 1875-1881 yılları arasında, zeytinyağı ihracatının düzensiz seyrini devam ettirdiği tespit edilmektedir. 1875 yılında İzmir Limanı'ndan 415 ton, 1876 yılında 350 ton, 1877 yllında 4.730 ton, 1878'de 4.776 ton, 1879 yılında 6.550 ton, 1880 yılında 310 ton ve 1881 yılındaysa 4.200 ton civarında zeytinyağının ihraç edildiği rapor edilmiştir. 1882-1892 yılları arasındaki on yıllık dilimdeyse, İzmir'den ihraç edilen zeytinyağı miktarının dalgalı seyrini koruduğu anlaşılmaktadır. 1882 yılında 7.250 varil, 1884 yılında 7.900 varil, 1885 yılında 7.200 varil, 1886 yılında 5537 varil, 1888 yılında 3.086 varil, 1890 yılında 7.578 varil, 1891 'de 7.030 varil ve 1892 yllındaysa 7.240 varil İzmir limanından zeytinyağı ihraç edildi. ${ }^{105}$ Avrupa ülkelerinin büyük rağbet gösterdiği İzmir ve çevresinde üreti-

101 Abdullah Martal, "XIX. Yüzynl Osmanlı Ekonomisi ve Bat Anadolu'da Kooperatif̧̧iliğg Yol Açan Ekonomik Gelişmeler”, Tariş Tarihi, İzmir, 1993, s. 16.

102 Melih Gürsoy, Tarihi, Ekonomisi ve İnsanlan ile Bizim İzmirimiz, Metis Yay., İzmir 1993, s. 63.

103 Cevat Sami-Hüseyin Hüsnü, İzmir 1905, [haz. Erkan Serçe], İzmir, 2000, s. 27.

104 Saadet Tekin, agt., s. 127 ve ayrıca bkz. Mehmet Başaran, age., s. 77, 84, 85.

105 Söz konusu değerler Accounts and Papers resmi yayınlarındaki verilerden yararlanılarak hazırlanmıştır. Kaynak için lütfen bkz. Parliamentary Papers, Accounts and Papers [1864-1912], "Commercial Reports" from Consular Offices in Turkey, [Annual Reports-Great Britain], Smyrna [İzmir]. 
len zeytinyağlarının kendi aralarında, hangi oranlarda paylaştıklarına ilişkin bir örnek 1889 yılı için verilebilir. 1889 yılında, İzmir limanından İngiltere'ye ihraç edilen zeytinyağı miktarı 24.041 kentaldir. Sözü edilen yılda İsveç, Norveç, Danimarka, Almanya ve Belçika gibi Baltık Ülkeleri'nin İzmir Limanı'ndan aldıkları zeytinyağı miktarıysa, 10.067 kental düzeyindedir. Avusturya-Macaristan'ın 4.508 kental, diğer ülkelerinse 4.748 kental İzmir'den zeytinyağı alımı yaptıkları tespit edilmektedir. 1 kentalin, 56 kilo olduğu göz önünde tutulması halinde bu ihracat değerlerinin yüzdelik dilim içindeki payları dikkat çekici sonuçlar ortaya koymaktadır. 1889 yılında İzmir'den ihraç edilen zeytinyağının, \%56'llk dilimini İngiltere'nin, \%23'lük dilimini Baltık Ülkeleri'nin, \%10'luk dilimini Avusturya-Macaristan'ın ve \%ll'lik dilimini de diğer ülkelerin satın aldığı anlaşılmaktadır. Bu haliyle XIX. yüzyılın sonlarına doğru zeytinyağında, İngiltere en büyük alıcı konumunu koruduğu ve onu Baltık Ülkeleri'nin izlediği söylenebilir. ${ }^{106}$

XIX. yüzyılın hemen hemen her döneminde, İzmir'in hinterlandı Büyük Menderes havzasından gelen zeytinyağı, Küçük Menderes ve Gediz havzalarından gelen zeytinyağından daha yüksek fiyatlarla satıldı. İzmir'den ihraç edilen zeytinyağı kalitesinin, bölge içinde tüketilen zeytinyağından daha düşük olduğunu da belirtmek gerekir. Midilli veya Edremit zeytinyağları, İzmir'in hinterlandında yer alan vadilerin zeytinyağlarından hem daha yüksek fiyatlarla alıcıyla buluşuyordu ve hem de Avrupa piyasası tarafından daha çok talep ediliyordu. Üreticiler yağı doğrudan piyasaya sürmek yerine, hasat esnasında zeytinlerini tüccarlara satmayı tercih ediyor, bu zeytinleri satın alan fabrika sahipleriyse çıkardıkları zeytinyağları İzmir'e gönderiyordu. ${ }^{107}$ Zeytinyağı gemiye teslim etmek üzere satılır ardından yağ, satıcı tarafından gemiye tulumlarla taşınarak burada varillere doldurulurdu. ${ }^{108}$

Savaş dönemlerinde, bölge tarım ekonomisinin içine düştüğü dar boğazlar bilinir. Ayrıca savaş nedeniyle sekteye uğrayan ticari ilişkilerdeki bozukluk, ürünün pazarlanmasında zorluklar yaratır ve ürün rekoltesi düşer. ${ }^{109}$ Buna ilişkin örnekler çoktur. I. Dünya Savaşı'nın ilk yıllarında Marmara havzasında zeytin mahsulünden yeteri kadar verim alınamaması, bölge ekonomisinde sıkıntı yaratmıştı. Aynı dönemde Ayvalık, Edremit kazalarıyla, Aydın vilayetinde zeytin mahsulünden büyük verim elde edilmişti ancak buralarda da amele sıkıntısı yaşanıyor ve fabrikaların çalışmaması, bölge zeytininin zarara uğramasına neden oluyordu. Müslüman ahalinin savaşta olması, bu mahsulün zarara uğ-

\footnotetext{
106 Abdullah Martal, Değişim Sürecinde İzmir'de Sanayileşme, age., s. 93.

107 Cevat Sami-Hüseyin Hüsnü, age., s. 202.

108 Karl Von Scherzer, age., s. 70.

109 Kemal Arı, “Türk Kurtuluş Savaşı'nın Bitiminde İzmir'in Genel Ekonomik Durumu”, Çağdaş Türkiye Araştırmalan Dergisi-Kurulusunun 70. Yil Dolayssyla İzmir Sempozyumu-, I/3, İzmir, 1993, s. 38.
} 
ramadan toplanmasını engelliyordu. Bölge ekonomisi için büyük değer taşıyan zeytinin toplanıp, yağının çıkarılması için, bu yerlerden gönderilen Rum ahalisinin bir kısmının kısmen iadesi veyahud kadınların gelmesine müsaade edilmesi ve çiftçi efradından lüzumu miktarının tahsisi bile düşünülmüştü. ${ }^{110}$

İzmir ve hinterlandında tarıma bağlı sanayinin en başat örneklerinden olan zeytinyağı ürünü, genelde sezon başında toplanan olgun zeytinlerin preslenmesiyle elde edilmekteydi. İzmir'in hinterlandında köylü, asırlardan beri zeytinden yağı aynı metotları kullanarak çıkarıyordu. "Meyve, parçalamanın yapılacağı değirmenin yakınında büyük bir haznede toplanır, bu değirmen basitçe ortasında dikey bir direğin bulunduğu bir tanktır ve büyük bir taş etrafında döner. Taşa yatay bir direkle bağlanan bir at, sistemi yavaş ve devamlı olarak çevirir. Bu yatay kazığa bağlı iki taş bununla birlikte sürüklenir. Tankın içine yeterli miktarda meyve atılırsa makine harekete başlar ve bir kişi meyveleri taşların altına itmek için demir bir direk ile atı sürer. Kısa bir süre sonra, taşların eylemini kolaylaştırmak için yaklaşık iki galon kadar kaynar su dökülür ve gerekirse daha fazla eklenebilir. Bu işlem kütle kalın bir macun kıvamına gelene kadar devam eder. Kütle daha sonra büyük bir kaba konup prese dökülür [...] Çıkan yağ açık yeşil renktedir ve presin yakınında bulunan büyük bir kavanoza alınır."111 Elde edilen bu sofralık zeytinyağlarının, parlak sarı renkte olanlarıyla kokusuz durumda bulunanları kalitesinin yüksekliğini gösteren unsurlardı. Bölgede zeytinyağının işlenmesi için kurulan fabrikaların yetersizliği, sıra bekleyen zeytin ürününün kalitesinin bozulmasına yol açmaktaydı. Elde edilen ürünün büyük kısmı iç piyasada tüketilmekte, ürünün yaklaşık dörtte biri ihraç edilmesi için İzmir Limanı'na gönderilmekteydi. ${ }^{112}$

İzmir ve çevresindeki zeytinyağı, kabaca pres edildiğinden yemek için uygun değildi. 1880'lerin başında zeytinyağının, İzmir Limanı'ndan en önemli alıcıları içinde başta İngiltere gelmekte ve bunu Fransa, Almanya, Hollanda, İtalya, Avusturya ve Rusya izlemekteydi. Kalite bakımından Ayvalık ve Edremit zeytinyağı, Avrupalılar tarafından daha çok tercih edilmekteydi. İkinci kaliteyse, Midilli'dir. Üçüncü kalite olarak, Aydın ve Bayındır zeytinyağları vardır. Üç kalitedeki zeytin, İzmir ve çevresinde preslenmektedir. 1880’lerin başında, ylllık ortalama mahsul 11.000 ton civarında olup, nakliye, vergi, varil giderleri de zeytinyağı fiyatlarını etkilediğinden ürün İzmir piyasasında yüksek fiyatla satılmaktaydı. Ton başına fiyatı, 40.000 sterline varmaktaydı. ${ }^{113}$ Eldeki veriler, XIX. yüzyılın ortalarında henüz yağ çıkarma sanayinin kurulmamış olmasından dolayı, hinterlanttan İzmir piyasasına

110 B.O.A., MV. $211 / 15$ [1917].

111 “Olive Cultivation In Turkey," Journal Of The Society Of Arts, 32 [1883 Nov. 23-1884 Nov. 14], s. 1075.

112 Accounts and Papers, Vol. 103, Smyrna, 1910, s. 8.

113 Accounts and Papers, No. 25, Smyrna, 1883, s. 1056. 
gönderilen zeytinyağı ürününün genelde düşük kalitede ve miktarda olduğuna ilişkindir. ${ }^{114}$ İzmir ve art alanının özelikle zeytin yetiştirmeye çok elverişli olması, ne kadar ilkel olursa olsun bir yağ çıkarma sanayisinin gelişmesine yol açması doğaldı; ne var ki belirli bir gelişme düzeyine erişmiş olan bu sanayi, iyi kalite yemeklik yağı ve sınai amaçlarla kullanılan yağları üretmekte başarı sağlayamadı. Hatta XIX. yüzyılda İzmir ve art alanı, Fransa'ya ve İtalya'ya zeytin ve zeytin ezmesi ihraç ederek, bu ülkelerden zeytinyağı bile ithal ettiği dönemler oldu. ${ }^{115}$ İzmir ve hinterlandında bol miktarda yetiştirilen zeytin, yağ sanayi için büyük bir potansiyel oluşturmasına karşın, bu dalda uzun zaman eski üretim biçimlerinin kullanılmasıyla yetinilmesini yabancı tüccarların ve onlara aracılık eden yerli azınlıkların yağ ticaretinden sağladıkları çıkarları, kendileri için yeterli görmelerine ve fabrikalar kurmak için fazla çaba göstermemelerine neden oldu. ${ }^{116}$ Nitekim 1891 yllında Hadkinson, Aydın'da bir zeytinyağı fabrikası kurup; yemeklik yağ, yağı çıkarılmış olan zeytin posası, bir kez daha ezilip yağlama işlerinde kullanılan daha düşük kalitede yağ ve ayrıca bunlardan başka üç tür yemeklik yağ daha üreterek, en sonunda elde edilen posada çok iyi kalite sabun yapımında kullanılabilen zeytinyağının yan ürünlerini üretmişti. Fabrikaların bu yolla elde edilen zeytin posasını kendisi işlemeyen Hadkinson, bunları İzmir'de bir sabun fabrikası bulunan R. Rose adlı bir İngiliz'e satıyordu. ${ }^{117} 1900$ yılına gelindiği zaman Hadkinson, Batı Anadolu'nun en büyük yağ üreticisiydi. Tüccarlıktan sanayiciliğe geçen bu İngiliz'in, Batı Anadolu'da sahip olduğu on zeytinyağı fabrikası, İzmir'e yerleşmiş İngiliz tüccarlarının yağ üretimine duydukları ilgiyi artırıyordu. ${ }^{118}$

Hükümet, İzmir ve çevresinde tarımsal üretimi ve buna bağlı olarak tarıma bağlı sanayiyi desteklemekteydi. Örneğin Seydiköy nahiyesinde, Felemenk tebaasından Wilhelm Muk adlı bir girişimci un öğütmeye ve zeytin sıkmaya mahsus inşa olunacak olan fabrika

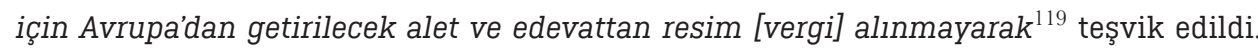
Benzer teşvikler pamuk, meyan kökü, palamut vb. fabrikaların kurulmasında da devam

114 H. 1300 Salname-i Vilayet-i Aydrn, s. 172

115 Orhan Kurmuş, age., s. 117.

116 Abdullah Martal, Deģ̆̆sism Sürecinde İzmir'de Sanayileşme, age., s. 143-144. XIX. yüzyllın sonunda tüm Anadolu'da olduğu gibi İzmir'in yakın hinterlant da büyük sanayi kuruluşlarının sahiplerinin çoğu gayrimüslimlerdi. Bunlardan biri de, Aydın'da buharla çalışır zeytinyağı fabrikasının sahibi, Miss Lorm idi. "Aydın”, Yurt Ansiklopedisi, C. II, İstanbul, 1982, s. 995-996.

117 İzmir ve çevresinde sadece yabancı kapitalinin işletmelerinde üretilen sabunların ticareti yapılmıyor aynı zamanda yerli sabun üretimi de sürdürülüyordu. Aydın'da Bosnalı Ömer Muharrem adlı bir yerli girişimci meşhur sabun üretimini yıllardır sürdürüyordu. Öyle ki, bu imalatçı İzmir'de Belediye civarında, Dutlu sokak, 5 numarada büyük bir mağaza açmış, ününü Aydın'dan İzmir'e taşımıştı. Ahenk, 9 Teşrin-i Sani 1913.

118 Melih Gürsoy, age., s. 63-64; ve ayrıca bkz. Orhan Kurmus,, age., s. 117-120.

119 B.O.A. İ.RSM, 14/1319/B-8 [1901]. 
etmiştir. I. Dünya Savaşı'nın başlamasından kısa bir süre önce yayınlanan bir zirai istatistik, 1909-1910 yılları arasında İzmir ve yakın hinterlandında, üretilen zeytinyağı miktarı konusunda hayli ayrıntılı bilgiler sunmaktadır. Sözü edilen yıllarda Aydın'da 4.823.020 adet zeytin ağacı bulunmakta, bundan 11.959.100 kıyye zeytin danesi alınmakta ve bu sayede 3.135.681 kıyye zeytinyağı üretilmekteydi. Manisa'daysa 723.605 adet zeytin ağacından 4672052 kıyye zeytin danesi alınmakta ve bundan da 948632 kıyye zeytinyağı elde edilmekteydi. İzmir'deyse 2.083.490 zeytin ağacının varlığı 15.400.005 kıyye zeytin danesinin bulunduğu ve 1909-1910 yılı itibariyle 3.619.309 kıyye zeytinyağının elde dildiği istatistik cetvelinde yer almaktaydı. ${ }^{120}$

I. Dünya Savaşı yıllarında, Anadolu'da bu tarz iki yüz altmış işleme yeri vardı. Kapasitenin \%60'ı da İzmir Sancak’taydı. Bu yerler, yılda ortalama otuz ton zeytinyağı üretiminin \%95'ini üretiyordu. İhracatta liderliği İngiliz, İtalyan ve Alman olan yabancı firmalar alıyordu. İhracatlar 1878-1882 yıllarındaki ortalama on dört bin dokuz yüz tondan, 1908-1913 yılları arasında yaklaşık olarak on bir bin iki yüz tona düştü. Fakat yüksek fiyatlar sayesinde ihracatın değeri dört yüz elli altı bin sterlinden, dört yüz seksen bin sterline yükselmişti. ${ }^{121} 1913$ ve 1914 yıllarına ait Fransız tüccarlara, yardımcı olmak amacıyla yayınlanan bir Fransızca ticaret rehberinde, İzmir'in hinterlandında küçük ve orta ölçekli sanayi işletmelerinin neredeyse tamamı yabancılardan oluşmaktaydı. Zeytin ve zeytinyağına dayalı üretim biçiminin yaygın olduğu İzmir ve çevresinde, 1914 yılında başta Hacı Dimos, Hadkinson, St Magnisalis, Missir Mercurian firmalarıyla, Boyacıoğlu Cemal Bey, Georgiadis gibi büyük tüccarlara ait zeytinyağı sıkma ve yağ fabrikaları vardı. ${ }^{122}$

Sonuç olarak, XIX. yüzyılın ikinci yarısında İzmir ve çevresinde yer yer zeytinyağının afyon, üzüm, şarap gibi ürünlerin gerisinde bir talebi olduğu anlaşılmaktadır. Gerçi bunun temel sebepleri arasında, bölge içi ve İzmir'e ulaşım konusunda nakliye güçlüklerinin olduğu da bilinir. Üstelik İzmir ve çevresindeki zeytinyağlarından çok, kalitesi daha yüksek olan Midilli, Ayvalık, Edremit zeytinyağlarının Avrupalılar tarafından tercih edilmesi de göz ardı edilmemelidir. Savaş dönemlerinde fabrikalarının çalışmaması ya da işçi sıkıntılarının yaşanması da zeytinyağı ticaretini yakından ilgilendiren diğer faktörlerdir Dahası yeteri kadar fabrikanın olmaması yüzünden sıra bekleyen zeytinin kalitesinin bozulması ve bu yüzden elde edilen zeytinin büyük bir kısmının iç piyasada tüketilmek zorunda kalması da mutlaka belirtilmesi gereken bir başka ayrıntıdır. Gerçi fabrikaların yetersizliğine, yağın taşınma masraflarının da eklenmesi, zeytinyağının maliyetini

120 Söz konusu değerler, 1325 Senesi Asya ve Afrika-yı Osmani Ziraat İstatistiği, Dersaadet 1327 adlı eserdeki verilerden oluşturulmuştur.

121 Charles İssawi, age., s. 247.

122 Annuaire Oriental, Edition 1914. s. 1046. 
artıran nedenler arasında sayılabilir. Dünya piyasasının tüm taleplerine rağmen nakliye güçlükleri, daha çok iç piyasada tüketilmesi gibi nedenler yüzünden zaman zaman bölgeden elde edilen ürünün, ancak dörtte birinin ihraç edilmesi bu nedenle şaşırtıcı değildir. Söz konusu bu durum pamuk, tütün, susam gibi ürünlerin İzmir ticaretinde zeytinyağından rol çalmalarına da kapı aralamıştır. Köylü daha çok gelir getiren ticarileşmiş tarımsal ürünlere meyletmiş, buğday yerine pamuk, sebze yerine tütün, üzüm, susam ekmenin daha çok kar getireceğini düşünmüştür. Bu yüzden yer yer zeytinin geçimlik ve yemeklik üretimiyle yetinildiği tespit edilmektedir. Devlet, bilinçli ve denetimini kaybetmeden zeytinyağının sadece dış satımını değil aynı zamanda yerel üretim ve tüketimi konusunda da teşvik edici tedbirler almakta gecikmemiştir. Tüm bu ayrıntılar bir arada değerlendirildiğinde, XIX. yüzyılın ikinci yarısında İzmir ve çevresinde tarıma dayalı sanayi ürünleri arasında, zeytin ve zeytinyağı elbette ki önemsenmiştir ama bu haliyle öncelendiğini söylemek zor olsa gerek. 



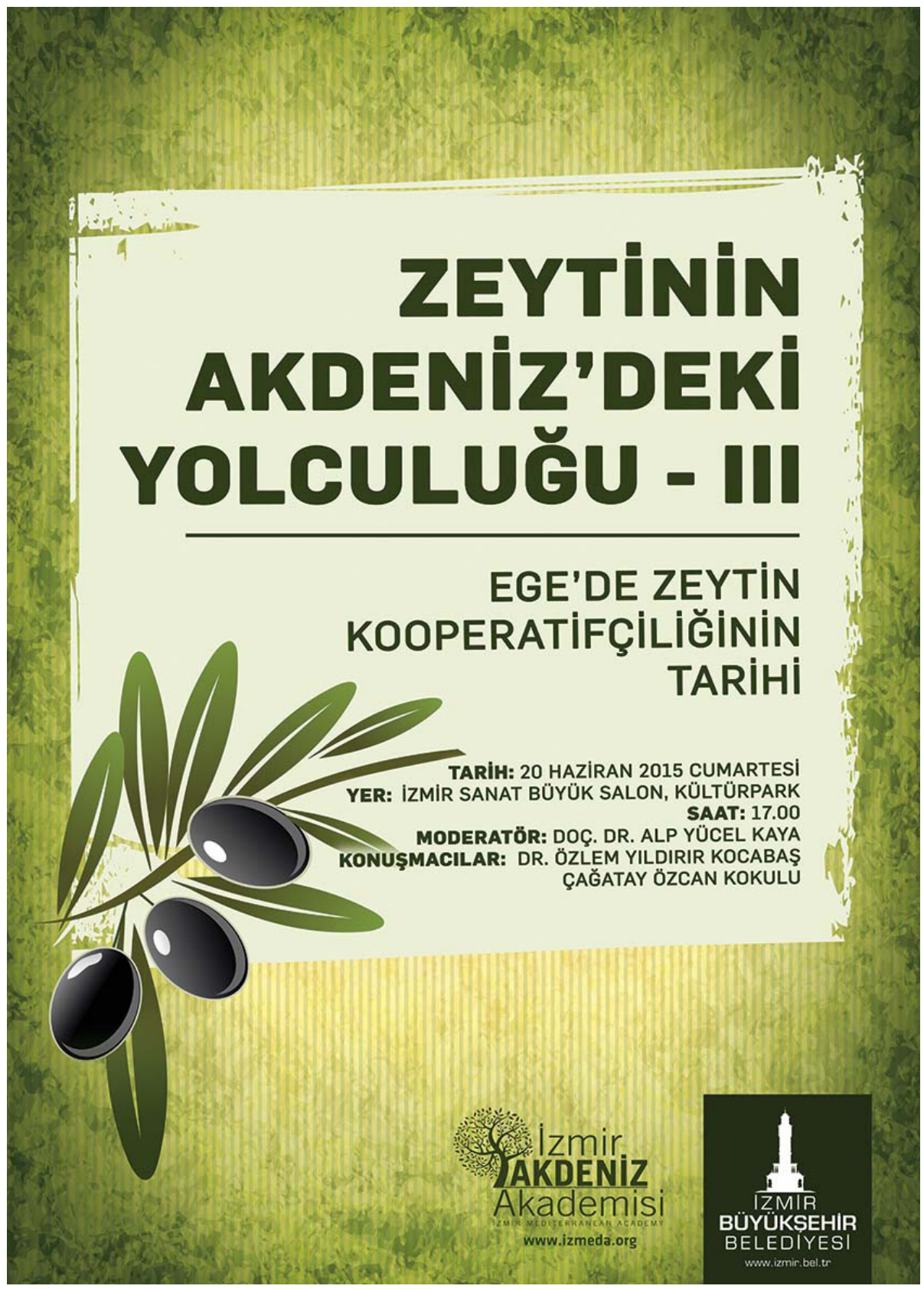




\section{Tariş Zeytin ve Zeytinyağı Tarım Satış Kooperatifleri Birliği Tarihi}

\section{Dr. Özlem YILDIRIR KOCABAŞ}

Dokuz Eylül Üniversitesi Öğretim Üyesi

İnsanlığın ilk çağlarından beri güç ve onur simgesi olarak nitelendirilen zeytin, insan yaşamında oldukça önemli bir yere sahip olmuştur. Atina'da olimpiyatlarda kazananların başlarına zeytin dallarından taçlar takılması, kutsal kitaplarda sürekli söz edilen bir meyve olarak adının geçmesi, bir onur simgesi olarak görüldüğünün bir göstergesidir. ${ }^{1}$ Eski ve köklü bir geçmişe sahip olan zeytin ağacl, iklimi Akdeniz iklimine benzeyen Kaliforniya, Arizona, Meksika, Arjantin, Şili, Brezilya gibi ülkelerde yetiştirilmeye başlamıştır. Türkiye, zeytin ağacının yetişmesi için uygun koşulları taşıyan ülkeler arasında yer almaktadır. $^{2}$

Zeytinden yağ elde edilmesi, büyük değişimlerden geçtikten sonra, günümüzdeki düzeye ulaşabilmiştir. Uygulanan ilk yöntemlerden birisi, ayakla zeytinin ezilmesi, sıcak suyla yağının alınması şeklinde olmuştur. İki taş arasında zeytinin ezilmesinde başlangıçta, insan gücü daha sonraysa hayvan gücünden yararlanma yoluna gidilmiştir. XIX. yüzyılda buharın kullanılmaya başlanmasıyla zeytinyağı sanayisi de yeni bir döneme girmiştir. Hidrolik preslerden dizel motor ve elektrikle çalışabilecek duruma getirilmesi ve modern zeytinyağı sistemi olarak kabul ettiğimiz kontinü sistemine kadar uzanan büyük bir evrim geçirmiştir. İzmir'de bir yağ fabrikası kurulması yolundaki ilk girişim, 1850'li yılların başında bir susam yağı fabrikası kurulmasıyla ilgilidir. Bu imtiyazdan sonra, 1873 yılında bir yağ fabrikasının kurulması için yurtdışından fabrika için araç ve gereç getirilmesi için ikinci bir girişim gerçekleşmiştir. 1875 yılında İngiliz tüccarlarından Hadkinson, İzmir'de bulunan ticaret evini kapatarak, zeytinyağı üretimine başlamıştır. ${ }^{3}$

1891 yılında Hadkinson, Aydın'da bir zeytinyağı fabrikası kurmuştur. Bu fabrikada zeytinyağının yan ürünlerini de üretmeye başlamıştır. Fabrikalarında elde edilen zeytin posasını kendisi işlemeyen Hadkinson, bunları İzmir'de bir sabun fabrikası bulunan R. Rose

1 Süleyman Aksu, Dünya Zeytinyağ Ekonomisi ve Türkiye, İzmir, 1972, s. 2.

2 Mehmet Ali Göktaş, Zeytin ve Zeytinyağınn Türkiye Ekonomisindeki Rolï, İzmir, 1966, s. 23.

3 Abdullah Martal, 19. Yüzylln İkinci Yansinda İzmir ve Çevresinde Sanayi ve Ticaret, İzmir, [D.E.Ü. Sosyal Bilimler Enstitüsü Doktora Tezi], 1992, s. 144-145; Erdal Aslan-Özlem Yıldırır, "Tariş Zeytin-Zeytinyağı Tarım Satı̧̧ Kooperatifleri Birliği”, Tariş Tarihi, Türkiye Toplumsal ve Ekonomik Tarih Vakfi Yay., 1993, s. 294 
adlı bir İngiliz’e satmıştır. Hadkinson, Batı Anadolu'nun en büyük yağ üreticisidir. İzmir'e yerleşmiş İngiliz tüccarları da yağ üretimine ilgi duymaya başlamışlardır. I. Dünya Savaşı'nın yaşandığı yıllarda, Anadolu'da iki yüz altmış işleme yeri bulunmaktadır. Bu yerler, yılda otuz bin ton zeytinyağı üretiminin \%95'ini üretmektedir. Zeytin ve zeytinyağına dayalı üretim biçiminin yaygın olduğu İzmir ve çevresinde 1914 yılında, Hacı Dimos, Hadkinson, St. Magnisalis, Missir Mercurian firmalarıyla, Boyacıoğlu Cemal Bey, Georgiadis gibi büyük tüccarlara ait zeytinyağı sıkma ve yağ fabrikaları vardır. ${ }^{4}$

Tarımsal ürünler içerisinde önemli bir yer tutan zeytin ve zeytinyağı, tüketim maddesi olmasının yanında ihracat yapılan bir madde olarak da önemli bir yere sahiptir. İspanya, Portekiz, İtalya, Tunus, Yunanistan ve Türkiye gibi ülkeler, zeytin üreticisidirler. Bu ülkelerin ihracatlarında zeytin ve zeytinyağının önemi büyüktür. II. Meşrutiyet yıllarında ‘kooperasyon' düşüncesi, güçlü sermayeler karşısında emeğin ucuzlaması, işçilerin aralarında dayanışma olmaması, hem sosyal hem de ekonomik açıdan kötü duruma düşmeleri sonucu yayılma göstermiş, kooperatifçilik için gerekli olan ortam doğmuştur. Osmanlı İmparatorluğu'nun içinde bulunduğu sorunların, ancak kooperatifçilik yoluyla çözüleceği bu dönemin düşünceleri arasında yer almaktadır. ${ }^{5}$

Aydın Kooperatif İncir Müstahsilleri Anonim Şirketi, II. Meşrutiyet yıllarının ‘Kooperasyon' ve 'Milli İktisat' politikalarının bir ürünü olarak ortaya çıkmıştır. İttihat ve Terakki Partisi'nin Aydın örgütü öncülüğünde kurulan şirket, ihraç ürünleri piyasasındaki koşullara bir tepki biçiminde, incir üreticilerini yabancı ve azınlık tüccarlarına karşı korumak, onlar karşısındaki durumu güçlendirmek amacını taşımaktadır. XIX. yüzyılın ikinci yarısında İngilizler, İzmir piyasasında en büyük alıcı ve satıcı olarak dış ticaretin büyük bir bölümünü ellerine geçirmişlerdi. Fransa ve Almanya'nın da katılımıyla Batı Anadolu bölgesinde kurulan bu şirketlerden en önemlisi, The Smyrna Fig Packers Limited Şirketi'dir. Köklü ve tabandan gelen bir hareketle bu şirketle mücadele etmek amacıyla, 31 Ağustos 1912 tarihinde Osmanlı, Aydın İncir ve Himaye-i Zürra Şirketi kurulmuştur. 13 Şubat 1913 yılında kuruluş nizamnamesinin yayınlanması nedeniyle, şirket belirtilen tarihte faaliyete başlamıştır. Ayrıca bu kooperatifi finanse etmek üzere 14 Mart 1914 tarihinde, Milli Aydın Bankası [Tarişbank] kurulmuştur. ${ }^{6}$ Şirketin kuruluş amacını özetlememiz gerekirse; ülkenin zirai ve ekonomik bakımdan önemli yöresinde halkın büyük çoğunluğunun çiftçilikle uğraşmakta olması, tefecilik yapanların yüksek fiyatla borç para vermesi

4 Cihan Özgün, Bereketli Topraklarda Üretmek ve Taşamak, İzmir ve Çeuresinde Ticari Tarm [1844-1914], İzmir Büyükşehir Belediyesi, İzmir, 2014, s. 216-217.

5 Özlem Yıldırır Kocabaş, Türkiye’de Tarmmsal Kooperatifçilik Düşüncesinin Gelişsimi, Libra Yay., 2010, s. 62-64.

6 Ayrıntılı bilgi için bkz. Tariş Tarihi, Türkiye Toplumsal ve Ekonomik Tarih Vakfı Yay., 1993; Tarişbank Tarihi [Milli Aydın Bankası], Türkiye Toplumsal ve Ekonomik Tarih Vakfi Yay., 1993. 
nedeniyle üreticiler büyük zarara uğramışlardır. Üreticiyi korumak ve bu şirketle mücadele etmek bu yıllarda büyük bir zorunluluk olmuştur. Aydın İncir ve Himaye-i Zürra Şirketi, kooperatifleşme hareketinin ilk temelini atmış oluyordu. Kurulan kooperatifler yörenin üretici, bağ ve bahçe sahibi, tüccar ve eşrafını bir araya getirerek güçlü ihracatçı ve tüccar sendikaları karşısına güçlü bir şekilde çıkmalarını sağlamıştır. Ege Bölgesi'nde üreticiyi 'kooperasyon' ilkeleri çerçevesinde örgütleyen kuruluş, Kooperatif Aydın İncir Müstahsilleri Anonim Şirketi'dir. Şirketin kurucuları; Kazım Nuri Çörüş, Nazmi Topçuoğlu, Ahmed Sarı'dır. Muhittin Birgen, Meslek gazetesindeki yazılarında, İzmir ve Ege Bölgesi'ndeki kooperatifçilik hareketine büyük bir ağırlık vermiştir. Ege havzasına vermiş olduğu önemi şu sözlerle dile getirmektedir: “Dünkü Türkiye'nin olduğu gibi bugünkü Türkiye’nin de en büyük en faal en feyyaz bir iktisat havzasıdır. Şimdi eski Aydın vilayeti havzasında, etraf ve havalisi ile birlikte büyük bir harabe halinde bulunuyor. Bununla birlikte Ege Bölgesi, kısa zamanda 'mamur' bir hale gelmek için gerekli koşullara da sahip bulunmaktadır."’

Cumhuriyet dönemine gelindiğinde; 1927 yılında Zeytincilik Kanunu Layihası'nın çıkarılmasıyla zeytin ağacı dikilmesi ve zeytinciliğin geliştirilmesi konusunda alınacak önlemler belirtilmiştir. 1923-1931 yılları arasında devletçilik politikası çerçevesinde, korumacı bir ekonomik politika belirlenmiş ve uygulamaya konulmuştur. 1929 yılında, Zirai Kredi Kooperatifleri Kanunu'nun çıkarılmasıyla tarımsal üretim düzene girmekte ve kırsal kesimin desteklenmesi sağlanmaktadır. ${ }^{8}$ Zeytincilik Kanunu'nun yürürlüğe girmesiyle, zeytinciliğin özendirilmesiyle ilgili en önemli adım, Mustafa Kemal Atatürk tarafından atılmıştır. Mustafa Kemal Atatürk, köylünün her alanda bilinçlenmesini istemektedir.

929 yılında Mustafa Kemal Atatürk, Yalova Millet Çiftliği'ne [günümüzdeki adı, Atatürk Bahçe Kültürleri Araştırma Enstitüsü] yapmış olduğu ziyarette, çiftliğin ıslah edilmesi ve modernleştirilmesi için zeytinciliğin kalkındırılmasının gerekliliği üzerinde durmuştur. Zeytinciliğin kalkındırılması için çiftliğin, dört bin verimi düşük olan ağaçları budanmış, sulama ve gübreleme gibi tarımsal önlemler alınarak zeytinlikler verimli hale getirilmiştir. İtalya'nın Peschia şehrindeki, Pietro Dacini fidanlığından altı bin adet zeytin fidanı ithal edilerek, Türkiye'nin ilk yabancı koleksiyon bahçesi oluşturulmuştur. ${ }^{9}$ Ayrıca Yalova, Orhangazi, Gemlik ve Mudanya zeytinliklerinin bakımı için İtalya'dan zeytincilik teknisyeni getirilmiştir. Zeytincilikle uğraşan köylerde, kurslar açılmıştır. Zeytincilikle ilgili bu gelişmeler sonrasında, 'Tarımda Tedrisat-ı Islahat Kanunu’ çıkarılmıştır. Bu kanunla

7 Muhittin Birgen, “Türkiye’nin En Mühim Servetlerine Sahip İktisat Havzası: İzmir”, Meslek, 15 Kanunuevvel 1924-24, 1925.

8 Özlem Yıldırır Kocabaş, Age., s. 119-124.

9 Martal, Agt., s. 144-145; Aslan-Yıldırır, agm., s. 295. 
birlikte, Avrupa'ya gönderilecek ziraatçılar arasında en başta zeytinciler gelmektedir. ${ }^{10}$ 1937 yılında, 3573 sayılı 'Zeytinciliğin Islahı ve Yabanilerin Aşılattırılması Hakkında Kanun' çıkarılır. 1937 yılında, İzmir Bornova'da fidan üretimi yapılması için, bir Zeytincilik İstasyonu'nun kurulduğunu görmekteyiz. İstasyon, 1950 yllında Zeytincilik Enstitüsü'ne dönüşecek, 1971 yılında Zeytincilik Araştırmaları Enstitüsü adını alacaktır. ${ }^{11}$

1935-1939 tarihleri arasında üzüm piyasasını elinde tutan, 'Tariş Üzüm Kurumu', ‘'̇zmir İncir ve Üzüm Tarım Satış Kooperatifleri Birliği'nin kurulmasında aktif rol oynamıştır. 28 Haziran 1937 tarihinde 'Tariş Limited Şirketi [Üzüm Kurumu]' ve 'İncir Kooperatifleri’, ‘'̇zmir İncir ve Üzüm Tarım Satış Kooperatifleri’ adını almıştır. 1939 yılı, birliğin idare yapısında da bazı değişimleri getiren bir yıl olmuştur. ‘Üzüm Kurumu’, 10 Haziran 1939 tarihinde tasfiye kararı almış ve bütün teşkilatını ve Tariş markasını, birliğe devretmiştir. Daha sonraki yıllarda pamuğun ve zeytinyağının da ana ürün olarak birliğe katılmasıyla, Ege Bölgesi'nin en güçlü tarım satış kooperatifi olarak tarım sektöründe önemli bir yere gelmiştir.

1937 yılında; on altı kooperatif ve üç bin sekiz yüz otuz altı ortağın bir araya gelerek oluşturduğu birlik, daha iyi bir kazanç elde edebilmek için yan ürün olarak hububat, pamuk, zeytinyağı, tütün, kendir, palamut gibi ürünler üzerinde de faaliyette bulunmuştur. 1940’lı ylllara gelinceye kadar, zeytincilikte üreticinin alın terini değerlendirebilecek nitelikte bir örgütlenmeye gidilememiştir. Yaşanan sorunları aşabilmek amacıyla, ‘̇̇zmir İncir ve Üzüm Tarım Satış Kooperatifleri Birliği'nin 27.10.1941 tarihli yönetim kurulu toplantısında, piyasadan alım yapılarak ürünün ihraç edilmesine karar verilmiştir. Zeytinyağı işini idare etmek için bir 'Yağ Servisi' oluşturulmasına ve Genel Müdürlükten uzman bir kadro istenmesine karar verilmiştir. Kuşadası'nda bulunan, Soka Yağ Tasirhanesi’nin satın alınması için incelenmek üzere heyet gönderilmiş ve bu heyet rapor hazırlamıştır. Raporda, Ticaret Bakanlığı'nın onayının alınması ve tesishane için, iki yüz altmış bin liralık bütçe ayrılmasına karar verilmiştir. ${ }^{12}$

1941 yılı içerisinde zeytinyağının teşkilatlandırılması yolunda bu adımlar atılırken, 1942 yılında zeytinyağı servisi kadrosu belirlenmiştir. Kuşadası'nda bir teneke fabrikasının yaptırılması, gerektiği kadar varil satın alınması ve İstanbul'da bir büro açılması düşünülmüştür. 1942 yılında, İzmir İncir ve Üzüm Birliği'ne zeytinyağı alımları başlamıştır. 1941-1942 iş yılında ilk kez zeytinyağı, kar ve zarar bilançolarında yer almıştır. 1942 yılındaki bu girişimlere rağmen, 1943 yılında zeytinyağı konusunda durgunluk yaşanmıştır.

10 Süleyman Aksu, Türkiye'de Zeytincilik Nasil Canlandrrllr, İzmir, 1984, s. 15-16.

11 Zeytincilik Araştırmaları Enstitüsü, Bakanlığa bağlı olarak araştırma, üretim ve eğitim alanında çalışmalarını İzmir Bornova'da sürdürmektedir.

12 İzmir İncir ve Üzüm Tarm Satı̧̧ Kooperatifleri Birliği Yönetim Kurulu Karar Defteri I, s. 212-213; s. 216-218. 
Ticaret Bakanlığı, bu sorunu çözmek amacıyla üreticinin elindeki zeytinyağının \%15’i ve muamele vergisi de dahil olmak üzere \%30'unu almak yoluna giderek, bu yolla elde edilen yağlarla sıkıntıyı gidermeye çalışmıştır. Bu görevin yürütülme görevi, İzmir İncir ve Üzüm Tarım Satış Kooperatifleri Birliği'ne verilmiştir. Birliğin topladığı yağlar, ordu ve halkın ihtiyacına gidermek için devlet denetimine verilmiştir. Piyasaya sürülen yağlar, sınırlı bir ölçüde de olsa zeytinyağı sıkıntısının giderilmesine yardımcı olmuştur. ${ }^{13} 1942-$ 1943 iş yılında Kuşadası Fabrikası, rafine ve sabun işlerinde çalıştırılarak zeytinyağının baş ürünler arasında yer alması sağlanmıştır. Aynı iş yılında Ayvalık, Edremit, Havran, Burhaniye ve Küçükkuyu Zeytinyağı Tarım Satış Kooperatifleri'nin birlik ortaklığına kabul edilmeleri, zeytinyağının kooperatifleşmesi yolundaki en önemli adım olmuştur. 1943 yılında, İzmir İncir ve Üzüm Tarım Satış Kooperatifleri Birliği'ne bağlı, Zeytinyağı Tarım Satış Kooperatifleri gerçekleştirilmiştir. Zeytinyağının kooperatifleşmesindeki esas amaç, II. Dünya Savaşı'nın olumsuz etkilerinden koruyarak zeytinyağı üreticisini tüccar, komisyoncu, işletmeci gibi vurguncuların elinden kurtarmaktır. Sultanhisar, Edremit, Burhaniye ve Bayındır kooperatiflerinde birer zeytinyağı fabrikası kurulmuştur. ${ }^{14}$

1947-1948 yılına gelindiğinde, zeytin hasadı mevsiminde devlet, üreticinin zeytinyağını üretim bölgelerinden alarak birlik aracılığıyla, tanzim satışlar şeklinde tüketiciye sunmuştur. ${ }^{15}$ II. Dünya Savaşı'na son anda kağıt üzerinde girmiş olsak da, yıkıcı etkileri tüm alanlarda olduğu gibi zeytinciliğe de yansımıştır. Üretken nüfusun pek çoğunun silah altına alınması üretimi düşürürken zeytinciliği de geriletmiş, yağ sıkıntısı bütün piyasaya yansımıştır. İç piyasayı düzenlemek amacıyla hükümet tarafından oluşturulan Devlet Yağları İdaresi'ne ait bütün işler, birliğe yüklenmiştir. Vergi tahsildarı durumuna düşürülen kooperatifler, yolsuzluklara da karışınca bu olumsuzluklar kooperatiflerin gelişememe nedenlerinden olmuştur. II. Dünya Savaşı'nın 1949 yılında sona ermesinin dışında, zeytinyağı sanayisinde de bazı gelişmeler yaşanmıştır. Koçarlı, Umurlu, Ortaklar, Germencik, Kırkağaç ve Bayındır'da birer zeytinyağı tarım satış kooperatifi açılmıştır. Ayvalık'ta İzzet Basmacı'ya ait zeytinyağı fabrikası, Umurlu'da Halit Çayırlı'ya ait bir zeytinyağı fabrikası satın alınmıştır. Ortaklar'da ve Koçarlı'da tasirhane [yağhane] yaptırılması, Sultanhisar'da zeytinyağı fabrikasının onarılması, Küçükkuyu Kooperatifi'ne arsa ve kooperatif bürosu, yağ deposu, lojman inşa edilmesi, Burhaniye Kooperatifi için İtalya'dan yağ makineleri getirilmesi gibi işler gerçekleştirilmiştir. 1946 yılından sonra başlayan Marshall yardımından yararlanarak Aydın, Umurlu, Köşk, Aliağa, Ortaklar, Bozdoğan,

13 Yeni Asir, 17 İlkkanun 1943; Yeni Asır, 5 Mart 1943.

14 Aslan-Yıldırır, agm., s. 300,301.

15 Mehmet Ali Göktaş, “Türkiye Ekonomisinde Zeytinyağı ve Meseleleri”, Türkiye Yağ Sanayii Semineri IV, Ankara, 1965, s. 63. 
Akhisar, Edremit, Havran, Küçükkuyu'da bir tasir fabrikası kurulması ve Aydın ve Burhaniye'de birer prina fabrikası kurulması için çalışmalara başlandı. ${ }^{16} 1949$ yılına gelindiğinde yaşanan en önemli gelişme, İzmir İncir ve Üzüm Tarım Satış Kooperatifleri Birliği'nin dört ana ürün üzerinden ayrı ayırı birliklere aỵılmış olmasıdır. Bu karardan sonra, her birlik, tüm işlemlerini kendi hesabına almıştır.

1950'li yıllara kadar, hükümetlerin tarımda verimliliği ve üreticiyi özendirici bir politika izlemelerine karşın, 1950'li yıllardan sonra parti politikalarının, çıkar gruplarının, tüccar sınıfının kooperatifler ve birlikler üzerindeki baskıları olumsuz yönde etkileyen girişimlerdendir. Marshall yardımı kapsamında, zeytinyağı yerine mısırözü yağı ve margarinle tanışmaya başlamamız olumsuz gelişmelerdendir. ${ }^{17} 1952$ yılına gelindiğinde, kooperatif sayısının on beşe çıkması ve Ayvalık, Burhaniye, Sultanhisar, Koçarlı ve Bayındır fabrikalarının yanında Ortaklar'da açılan yeni fabrikayla, sayının altıya yükseldiği görülür. 1954 yılına gelindiğinde, kooperatif sayıları on sekize ulaşmıştır. 1955 yılında Edremit’te bir sabun fabrikası açılmış ve sabun imal edilmiştir. 1956-1957 yıllarında Akhisar'da yağ fabrikası ve Milas deposu açılmıştır. 1958 yılına gelindiğinde, yağ sıkıntısına çözüm bulmak amacıyla yağ satışları durdurulmuş ve Tariş'in elindeki zeytinyağına el konmuştur. Yem Sanayii T.A.O. ile ortak olarak kurulan, Tariş Yem Sanayii Limited Ortaklığg'na iştirak edilmiştir. 1963 yılında, Tariş yağ ithalatına başlamıştır. Zeytinyağı Birliği, 1964 yılında piyasaya Tama ve Tarin markasıyla yemeklik ve kahvaltılık iki yeni ürün piyasaya sürmüştür. 1965-1966 iş yılında Selçuk ve Ezine'de birer zeytinyağı tarım satış kooperatifi kurulmuş ve kooperatif sayısı, yirmi bire ulaşmıştır. 1970 yılından itibaren, Rafine Zeytinyağı Fabrikası ve ek tesisleri tamamlanmıştır. 1970-1971 yıllarında ülkemizde zeytinyağı rekoltesi, yüz bin tondur. Bu miktarın, seksen bin tonu Ege Bölgesi'nde üretilmiştir. Aynı yıl içerisinde, Çine ve Edremit’te zeytinyağı fabrikası kurulmuştur. Yeterince ürün alınamadığından faaliyete geçememişlerdir. ${ }^{18}$

1973-1974 yılında devlet destekleme alımları olmadığı için, Ege Bölgesi'nde ortak ve ortak dışı üreticiye ait ürünlerin iç ve dış piyasalarda en iyi koşullarda değerlendirilmesine çalışılmıştır. 1975-1976 yılında Türkiye zeytinyağı rekoltesi, doksan dört bin ton, Tariş Zeytinyağı Tarım Satış Kooperatifleri Birliği ortaklarının taahhüt ettikleri miktar, on bir bin yedi yüz on yedi tondur. Ege Bölgesi rekoltesi, bu iş yılı içerisinde yaklaşık olarak, yetmiş beş bin ton dolaylarındandır. 1979 yılına gelindiğinde, toplam kooperatif sayısı yirmi dörte ulaşmıştır. 1979-1980 yılında Ege Bölgesi rekoltesi yaklaşık olarak, kırk sekiz bin tondur. 1980 darbesinden sonra, Tariş'e bağlı birlikler genel kurullarını ancak 1985

\footnotetext{
16 Aslan-Yıldırır, agm., s. 303,304.

17 “Zeytinyağh Tiyemem Aman ....” türküsü aslında bu dönemin yaklaşımını yansıtmaktadır.

18 Aslan-Yıldırır, age., s. 305-313.
} 
yılında yapabilmişlerdir. 1980-1981 yıllarında, Türkiye zeytinyağı rekoltesi, yüz yetmiş bin ton olup bunun yüz otuz altı bin tonu Ege Bölgesi'nden elde edilmiştir. 1981-1982 yıllarında dört katlı depo inşaatına başlanmıştır. Ayrıca, Ayvalık'ta birliğe ait arsa üzerinde kurulacak Kontinü Zeytin Sıkma Tesisi projeleri hazırlanmıştır. 1985-1986 yıllarına gelindiğinde, zeytinyağı üretimi yok yılı olarak geçmiştir. 1986-1987 yılları arasında ürün döneminde zeytincilikte yaşanan kriz, devlet eliyle toplu ilaçlama yapılması sonucu bir düzelme göstermiştir. Birliğe yapılan ortak ve ortak dışı teslimatların miktarında da olumsuzluklar yaşanmıştır. Zeytinyağı tarım satış kooperatifleri birliğinin ülke rekoltesinden aldığı payın düşük olmasının esas nedeni, fiyatların piyasadaki dalgalanmalar karşısında uyum sağlamakta güçlük çekmesidir. 1988-1989 iş yılında kuraklığın etkisiyle ortalamaların altında olan dünya üretimi, artış gösterse de Türkiye rekoltesinde aynı artış gözlenmemiştir. 1989-1990 yılında, birliğin ortak sayısı on beş bine, birliğe bağlı yirmi kooperatif işletmesinden sadece Erbeyli, Selçuk, Sultanhisar, Burhaniye, Edremit, Havran ve Zeytindağı kooperatiflerinden alınan iki yüz elli bir ton zeytin işlenmiştir. ${ }^{19}$

1991-1992 yıllarına gelindiğinde, ülkemiz zeytinyağı sektöründeki en önemli gelişmelerin başında zeytinyağının tekrar 'devlet destekleme alımları kapsamına' alınmış olmasıdır. Ülkemizin zeytinyağı rekoltesi, altmış bin ton olarak belirlenmiştir. Yine bu yıllarda, üründe yok yılı olmasına rağmen, zeytinyağı alımları kırk sekiz bin ton olan bölge rekoltesinin \%40'ını oluşturmaktadır. Ürünlerin dış piyasada pazar elde etme çabasıyla, Moskova'da düzenlenen Manage 92 Türk İhraç Ürünleri Fuarı'na bir standla, Parma İtalya'da düzenlenen Cıbus 92 Uluslararası Gıda Fuarı'na Beta Food firmasıyla müşterek olarak katılmıştır. Bin beş yüz doksan adet zeytin fidanı sağlanarak dağıtılmış ayrıca İzmir Valiliği'nden gelen talep üzerine Nahçıvan'a, yüz milyon liralık yardımda bulunulmuştur. ${ }^{20}$ Ege Bölgesi, zeytinciliğimizin ağırlık noktasını oluşturmaktadır. Üreticinin piyasadaki vurgunculardan korunarak, ortak ve ortak dişı üreticileri kooperatiflere çekebilmenin yolunu bulmak gerekmektedir. Fiyat politikaları sağlıklı olmalı, üreticiler tüccara değil kooperatiflere yönlendirilmelidir.

Türkiye'de kooperatifçilik hareketinin gelişimine baktığımızda, 1950'li yıllara gelinceye kadar kooperatif düşüncesinde yaşanan hızlı gelişim, daha sonraki yıllarda kanunlarda ve planlarda kendini göstermiş, kalkınma planlarında yer verilse de Cumhuriyet ve Atatürk dönemindeki ruhun tam olarak yakalanmadığı görülmektedir. Kooperatif hareketinin yeniden başarıya ulaşabilmesi için ticari, mali, ulusal, uluslararası, dayanışma temel alınmalıdır. Türkiye'de kooperatif hareketi içerisinde, İzmir'in ve Ege Bölgesi'nin

19 Aslan-Yıldırır, agm., s. 315-323.

2022 Şubat 1993 tarihinde yapılan Genel Kurula Sunulan 1991-1992, 43. İş Yilı Raporu, İzmir, 1993; AslanYıldırır, agm., s. 324-327. 
önemi büyüktür. Günümüzde kooperatif denilince sadece yapı kooperatiflerinin akla gelmesi, tarım sektörüne gereken değerin verilmemesi İzmir'deki ve Ege Bölgesi'ndeki kooperatifçilik hareketinin meşrutiyet ve Cumhuriyet yıllarındaki canlılığı ve hareketliliği kaybetmesinin başlıca nedenleri arasında sayılabilmektedir. Temel sorunlar çözülmeli, tarımsal kooperatifçilik, aracılık ve tefecilikle mücadelede, alımsatımda, sanayileşmede, demokratikleşmede, kamu ve özel sektörün yanında kooperatifçilik de üçüncü bir sektör olarak hak ettiği yeri almalıdır. 


\section{Kaynakça}

22 Şubat 1993 tarihinde yapılan Genel Kurula Sunulan 1991-1992, 43. İş̧ Yil Raporu, İzmir, 1993.

Aksu, Süleyman. Türkiye'de Zeytincilik Nasıl Canlanderlır, İzmir, 1984

Aslan, Erdal-Yıldırır, Özlem. "Tariş Zeytin-Zeytinyağı Tarım Satış Kooperatifleri Birliğı̀", Tariş Tarihi, Türkiye Toplumsal ve Ekonomik Tarih Vakfi Yay., İzmir, 1993

Göktaş, Mehmet Ali. “Türkiye Ekonomisinde Zeytinyağı ve Meseleleri”, Türkiye Yă̆ Sanayii Semineri IV, Ankara, 1965.

İzmir İncir ve Üzüm Tarm Satış Kooperatifleri Birliği Yönetim Kurulu Karar Defteri I-[Tariş Genel Müdürlüğü Arşivi]

Kocabaş, Özlem Yıldırır. Türkiye'de Tarmsal Kooperatif̧̧ilik Düşüncesinin Gelişimi, Libra Yay., İstanbul, 2010.

Martal, Abdullah. 19. Yüzylln İkinci Yarısnda İzmir ve Çevresinde Sanayi ve Ticaret, İzmir, D.E.Ü. Sosyal Bilimler Enstitüsü Doktora Tezi, 1992.

Muhittin, “Türkiye’nin En Mühim Servetlerine Sahip İktisat Havzass: İzmir”, Meslek, 15 Kanunuevvel 1924-24, Şubat, 1925.

Özgün, Cihan. Bereketli Topraklarda Üretmek ve Taşamak, İzmir ve Çevresinde Ticari Tarm [1844-1914], İzmir Büyükşehir Belediyesi, İzmir, 2014.

Tariş Tarihi, Türkiye Toplumsal ve Ekonomik Tarih Vakfi Yay., İzmir, 1993.

Tarişbank Tarihi [Milli Aydn Bankası], Türkiye Toplumsal ve Ekonomik Tarih Vakfi Yay., İzmir, 1993.

Yeni Ası, 17 İlkkanun [Kanunuevvel], 1943.

Yeni Astr, 5 Mart 1943. 


\section{Kırsal Kooperatifçilikte Gödence Örneği ve İzmir Kooperatifçiliğine Toplu Bir Bakış}

\section{Çağatay Özcan KOKULU}

Gödence Tarımsal Kalkınma Kooperatifi Başkanı

Son zamanlarda en çok duyduğum soru, "Zeytinyağı fiyatları neden bu kadar çok yükseldi?" oluyor. Kızıldağlar'daki bağ evimiz Efemçukuru, Çamtepe ve Kavacık köylerinin değirmen yolunun üstündeydi. Çocukluğum orada geçti. 0 yoldan değirmene giden köylüler, mutlaka rahmetli dedemin bağ kulübesine uğrarlardı. Komşu kâhyalardan, oğlak derisine basılmış on kilogramlık peynir karşıllğında, on kilogramlık zeytinyağı verdiğini bugünkü gibi anımsarım. Burada bulunmamızdan, neden umutlandım? İki yll önce hasat yapılamaz, sürdürülemez noktaya gelen zeytin ve zeytinyağıyla ilgili bu salonu dolduruyorsak, sektörün sorunlarını çözme konusunda da ciddi irade göstereceğimizin işaretini okuyorum, onun için mutlu olduğumu ifade etmek isterim.

Türkiye, petrolden sonra ithalatta ikinci kalem olarak en büyük payı, likit yağı için ödüyor. Daha önceki konuşmalarımızda, çiftçiyle sohbetlerimizde, Türkiye'nin zeytinyağı sektörü içindeki problemleri üretim, sanayici ve pazarlama bağlamındaki sorunların çözümünde, resmi devlet politikası olması gerektiğini belirtmiştik. Depolama konularındaki sıkıntılar, hala Türkiye zeytinyağı sektörünün önemli sorunlarının başında geliyor. Benim, üç kimliğim var. Birincisi emekçiyim, üreticiyim, tarlada çalışıyorum ve fili çiftçiyim. İkincisi, küçük çiftçinin temsilcisi olarak sanayiciyim. Üçüncüsü, sanayici olarak pazarlama organizasyonunu sürdüren, Gödence Tarımsal Kalkınma Kooperatifi'nin başkanıyım.

İzmir, Türkiye'de kooperatif organizasyonlarının en güçlü olduğu kentlerden birisidir. Menderes Havzası'nda Tire, Bademli; Kiraz'da İğdeli; Yarımada da Bademler, Gödence; Foça'da kooperatifler var. Bu kooperatif organizasyonları, çok ciddi işleri başarmış durumdalar. Şimdi size, Seferihisar bölgesinde İzmir'in hemen yakınında Kızıldağlar'da Gödence'de yapılan çalışmalardan bilgiler vereceğim. Sonrasında da, Türkiye'de kooperatif hareketinin bir kısa özetini çıkaracağım.

Bilindiği gibi 1968'li yıllar, Fransa'daki öğrenci hareketleriyle başlayan ilerici rüzgârların dünyaya yayıldığı yıllardır. Türkiye'ye yansıması da çok kısa sürede oldu. Kırsal alanda, kooperatifleşme hareketleri başladı. İlk olarak Urla Bademler'de, Ödemiş'te Bademli, Samsun'da Nergis kooperatiflerinin kurulduğunu görüyoruz. 1970 yılında, Yarımada da Gödence Tarımsal Kalkınma Kooperatifi kuruluyor. 1971 yılında, İzmir Kooperatifler Birliği'ni kurduk. 1974 yllına gelinceye kadar Bademli, Gödence, Ulamış, Dikili, Yahşibey 
başta olmak üzere yirmi sekiz tane kooperatif, zeytinyağında sanayi yatırımlarını yapmış oluyorlar. Tariş'ten sonra İzmir Kooperatifler Birliği, İzmir bölgesinin zeytinyağında en büyük sanayi gücü oluşuyor. 1975-1976 yıllarında İzmir Kooperatifler Birliği, dış satım için çok ciddi çalışmaların içine giriyor. Kemalpaşa bölgesinden Sosyalist Blok’a, Almanya ve Avusturalya'ya kuru üzüm ihracatı, Efemçukuru, Gödence, Kavacık köylerinden alfons ve razaki üzümü, Marmara Bölgesi'ndeki kooperatiflerden su ürünlerinin ihracatına başlanıyor, 1976 yılında Bağcılar Bankası kuruluyor. Köylüler, kooperatif aracılığıyla ve sadece kendi güçleriyle banka sahibi oluyorlar. Dünya'nın hiçbir yerinde olmamış olan, yaşanması mümkün olmayan bir olayı anlatmak isterim; o dönemde, bir kararnameyle Ticaret Bakanlığı, iktisadi kamu kuruluşlarının açıklarını kapatmak üzere Köy-Koop İzmir Birliği'nin kazançlarına, gelirlerine, banka hesaplarına el koydu ve itiraz hakkı, mahkemeye başvurma hakkı kooperatifin elinden alınmıştı. Bunun üzerine İzmir Belediye Başkanı İhsan Alyanak, İzmir Yaş Sebze ve Meyve Hali'nde bir lira karşılığında üç standı, İzmir Kooperatifler Birliği'ne sattı ve faaliyetlerimiz devam etti.

Türkiye'nin kooperatif organizasyonda, tarımın örgütlenmesinde en ciddi kırllma noktasını 1980 olarak görüyorum. Askeri darbeyle, Türkiye çok ciddi sıkıntılar, ciddi olumsuzluklar ve anti demokratik olaylar yaşanırken, bir o kadar da tarım ciddi bir sıkıntının içine girdi. "Yurtdışında daha ucuz, dışarıdan alırız" mantığı, bu olumsuzluğun başlıca kaynağıydı. 0 mantık, Turgut Özal'la bu ülkeye yapıştı. Türkiye, liberalleşmede çok şeytani bir zıplama yaşadı. SEK, Et Balık Kurumu satılmak istendiğinde, Köy-Koop olarak biz talip olduk ama çiftçi organizasyonlarına verilmedi. Tarımdaki organizasyon gücümüzle, bunu aşacağımıza inanıyorduk. Ancak şu anki geldiğimiz noktada, yerel ve lokal başarıların yetmediğini gördük. Mutlaka geniş tabana yayılan başarıları yakalamak gerekiyordu. İfade etmek isterim ki; tarımsal amaçlı kooperatifler, tüketicinin güvenebileceği en büyük dostudur. Gödence Tarımsal Kalkınma Kooperatifi slogan olarak, "Biz, tüketicinin en büyük dostuyuz" sloganını kullanmaya karar verdik. Kooperatif organizasyonları, yaşam kalitesinin yükseltilmesinin ötesinde, tüketiciyle üretici arasında çok sağlam bir köprüdür. Kooperatifler, ülke kalkınmasını ve küçük çiftçinin korunmasını sağlarken, bir o kadar önemli işlevi de yerel demokrasinin güçlenmesini dolayısıyla da ülkede demokrasi kültürünün gelişmesini sağlayan kurumlardır. Seçme, seçilme, söz söyleme hakkı, kendini ifade etme hakkı, bu organizasyonların içinde büyüyor, gelişiyor ve topluma etkin şekilde yaygınlaşıyor. 


\section{Gödence Tarımsal Kalkınma Kooperatifi’nin Tarihçesi}
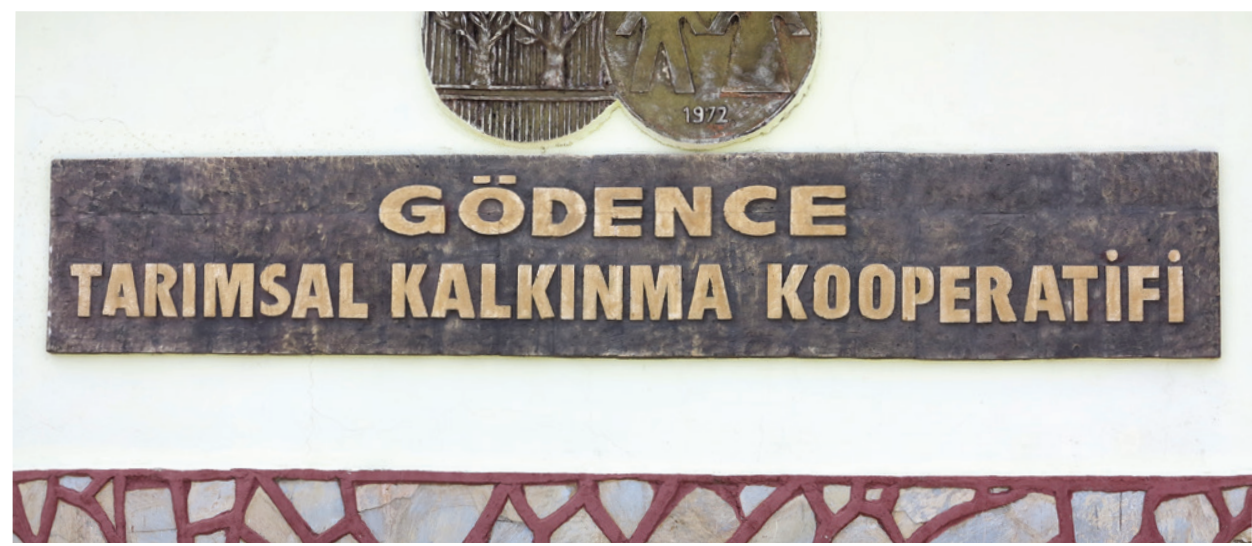

Kızıldağlar, Seferihisar Doğanbey Körfezi'nden başlayarak geniş bir yay çizer. Bir ucu Balçova üstüne, diğer ucu Menderes ilçesine ve Tahtalı Barajı'na iner. Bu dağlar, İzmir'in akciğerleridir. İzmir'in temiz bölgesi, yağış ve su havzasıdır. Gödence, bu dağlardaki beş köyden biridir. Geçmişi, üç bin yıl öncesine Antik Çağ'lara dayanır. 1800'lü yılların başında Konya bölgesindeki Selçuklu Türkmenlerinden göç alan Gödence'nin tarihsel süreç içinde zeytinyağıyla uğraşısı gelişerek büyümüştür.

Bu gelişmeyle birlikte, toplumsal ilerleme de devam etmiş ve 1970'li yıllarda örgütlenme tartışmaları gündeme gelmiştir. 1970'li yıllar, Gödence'de yoksulluğa karşı savaş açılan yıllardır. Emeğine sahip çıkma, kendini arayış, sanayileşme isteğinin ön plana çıktığı yıllardır. 1972 yılında Abdullah Duran, Ali Çetin, Muzaffer Uslu, Halil Hayta, Ümmet Aytekin, Mehmet Ali Algın ve Mustafa Mülayim tarafından kurulan Gödence Tarımsal Kalkınma Kooperatifi'nin o yıllarda dünyada esen ilerici rüzgârlarla, komşu köyümüz Bademler'deki kooperatifleşme hareketinden etkilendiği söylenebilir. Bugün bir masal gibi gelen faaliyetler, toplum olarak ne yazık ki yitirdiğimiz imece anlayışıyla başarılmıştır. 1990’lı yıllar, Gödence Tarımsal Kalkınma Kooperatifi'nde çalışma döneminin başladığı yıllardır. Hazırlanan beşer yıllık kalkınma ve gelişme planları, disiplinli bir şekilde uygulandı. Kooperatif, 1995 yılında teknolojisini Tarım ve Köy İşleri Bakanlığı'nın kredilerinden yararlanarak yeniledi. Aynı yıl, yetersiz olan köy elektrik şebekesi, kooperatifin iradesi ve katkılarıyla güçlendirilmiştir. İyi makinelere sahip olmanın çok şey ifade etmediğini fark eden Gödence Tarımsal Kalkınma Kooperatifi'nin ikinci beş yıllık kalkınma ve gelişme planının özünü, zeytinyağı kalitesinin yükseltilmesine yönelik çalışmalar oluşturdu. Üretim yapmanın yetmeyeceği, esas olanın üretimin kalitesi olduğu görüşü ve anlayışı kooperatifin tüm çalışmalarına yansıyacaktır. 1990'lı yıllarda başlayan markalaşma süreci artık tamamlanmış bulunmaktadır. Yaratılan yerel lezzet, kalite kavramlarının hayata geçi- 
rilmesi, Türkiye zeytinyağı sektörünün içinde Gödence Tarımsal Kalkınma Kooperatifi'ni hak ettiği yere taşımıştır. Gödence'de, zeytinyağı depolama sorunları büyük ölçüde çözülmüştür, hatta zeytinyağı lisanslı depoculuk deneme çalışmaları yapılmaktadır. Kooperatifin organizasyonuyla yaratılan gelişme ve kalkınma, Gödence'nin kırsal kalkınmada bir model olarak gösterilmesinin nedenidir. Gödence'de iş olanağı yaratmak, üreticilerin ürünlerine artı değer kazandırmak, kooperatif yönetiminin temel anlayışıdır. Yerel lezzetlerin markalaştırılması, kırsal turizm içinde önemli bir çalışma olarak görülmektedir. Gödence ev tarhanası, siyah ve yeşil salamura zeytin, bal, sirke, ev reçelleri, kurutulmuş domates ve badem kooperatifin zeytinyağı üretiminin dışındaki faaliyetleridir. Ülkemizde, Gödence Tarımsal Kalkınma Kooperatifi, İzmir'deki önemli kooperatif üslerinden biri olarak gösterilmektedir.
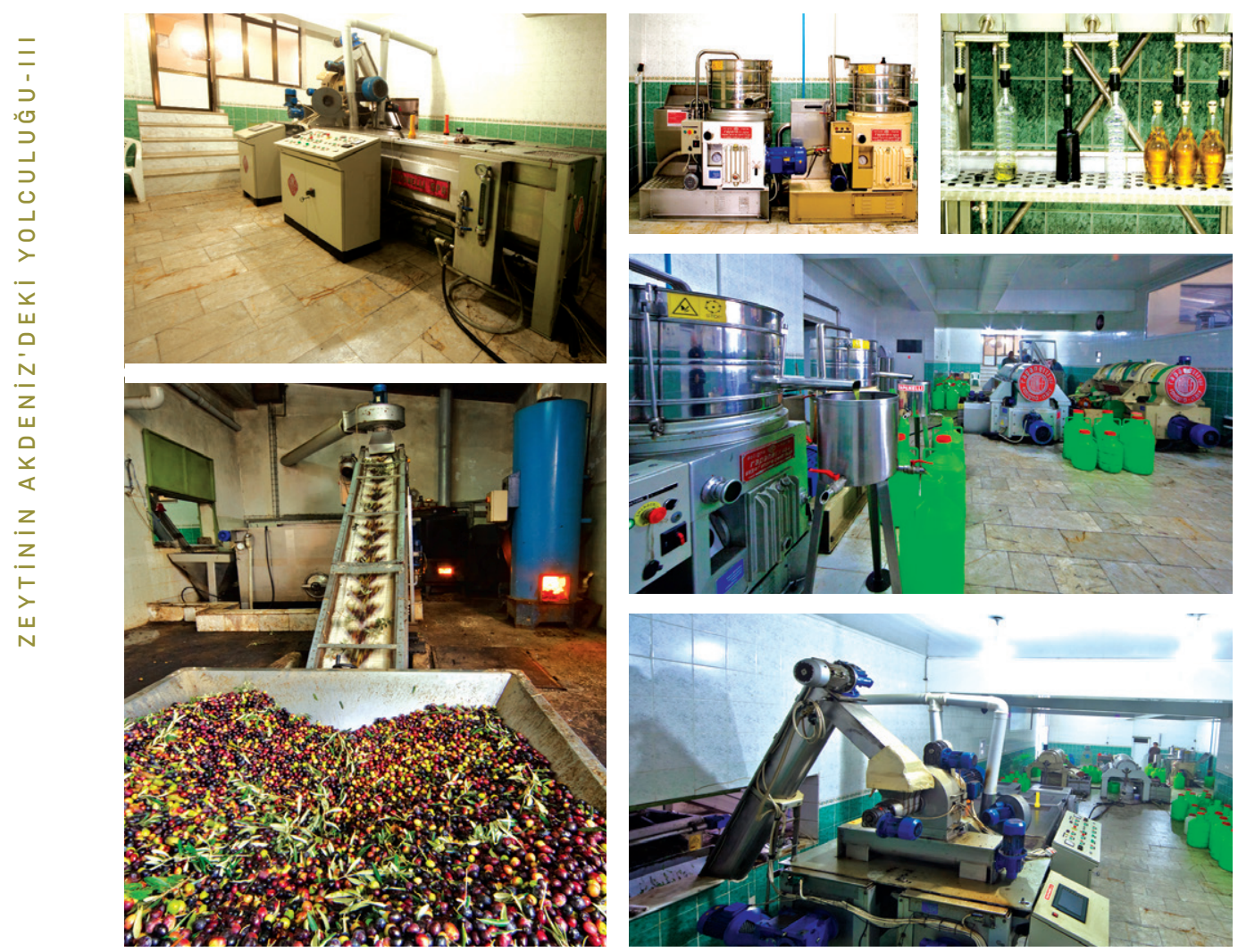

Bu nedenle yerli ve yabancı konukların Gödence'yi ziyaretleri ülkeler ve bölgeler arası deneyim, paylaşım ve bilgi akışını sağlamaktadır. Yürütülen çalışmalarda, kültürel ve toplumsal değerlerimizin korunması büyük önem arz etmektedir. Toplumumuza karşı sorumluluğumuzun hiçbir zaman bitmeyeceği Gödence'de, çalışmaların özünü oluşturmaktadır. Bu anlayışla, ‘Gödence Tarım Başarı Ödülleri’ doğmuştur. 



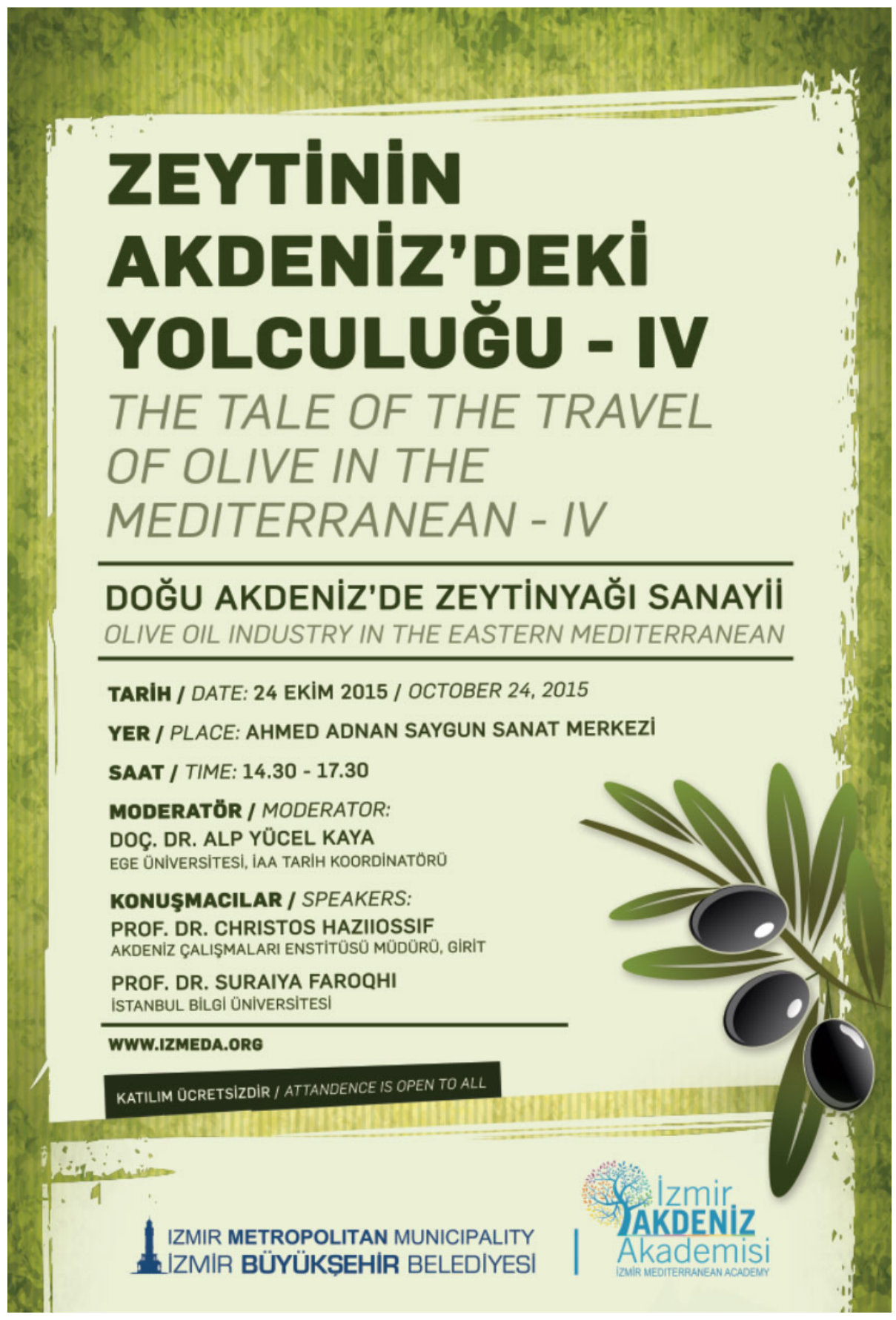




\section{Zeytin ve Zeytinyağının Tarihselliği}

\section{Prof. Dr. Christos HADZIIOSSIF}

Girit Akdeniz Araştırmaları Enstitüsü-FORTH

Olea europea. Botanikçiler, zeytin ağacını Akdeniz havzasının yerlisi gibi göründüğünden, olea mediterranea diye adlandırabilirlerdi. Zeytin ağacının genetik parmak izi, türün ilk kez Akdeniz'in iki farklı bölgesinde, yani Yakındoğu ve Kuzey Afrika'da son buzul çağından sonra ortaya çıkmış olduğunu ele veriyor. ${ }^{1} 0$ zamandan beri, zeytin ağacı Akdeniz coğrafyasının parçası olmuştur ve Akdeniz sakinlerinin gündelik hayatlarıyla o kadar iç içe geçmiştir ki XIX. yüzyıldan, XX. yüzyıla geçerken, büyük coğrafyacılar, sonra da tarihçi Fernand Braudel Akdeniz bölgesinin sınırlarını zeytin ağacının yayıldığı sınırlar olarak belirlemiştir. ${ }^{2}$ Buradan da anlaşlacağı gibi zeytin başlığı, İzmir Akdeniz Akademisi kurumu için biçilmiş kaftan.

Bu metnin amacı, insan toplumlarının zaman içinde zeytinle sürdürdükleri karmaşık ilişki üzerine birkaç düşünce sergileyerek, gelecek araştırmalara bir parça yön vermektir. Akdeniz çevresinde zeytin ağacının sürekli varlığına karşın, dikimi ve meyvelerinin kullanılmasının zaman içinde değişiklik gösterdiğini belirtmem gerekir. Zeytin, bize çağdaşı insan toplumlarıyla ilgili çok şey anlatabilecek bir tarihe sahip. İzninizle bir örnek vereyim: Paris'te ve Avrupa'nın kuzeyindeki pek çok apartmanın balkonlarında görebileceğimiz çiçek açmış zeytin ağaçları, iklim değişikliğinin sadece zeytinin değil, diğer Akdeniz bitkilerinin de sınırlarını Kuzey’e doğru itmekte olduğunu gösterir. Zeytin, Akdeniz diyeti denilen şeyin son popülaritesine de tanıktır. Eğer Fernand Braudel başyapıtı Akdeniz'i bugün yayınlamış olsaydı, kesinlikle haritalarını yeniden çizerdi. Braudel'in tarihsel zaman şemasında, insanın doğal çevresiyle etkileşim yollarındaki değişiklikler, doğal çevrenin kendisindeki değişikliklerden daha kısa zaman aralıklarında gerçekleşir. İnsan ilişkilerindeki değişim temposu, insanın doğal çevresiyle ilişkisindeki değişiklikten daha hızlıdır. Zeytinin tarihi, hem insanın çevresiyle etkileşimi, hem de bu bitki çevresinde dokunmuş toplumsal ilişki açısından değişikliklerle doludur.

Bugün zeytin ve zeytinyağı gıda maddeleri olarak önemlidir. Ancak durum her zaman böyle değildi. İnsan, zeytini Neolitik dönemde, zamanımızdan altı bin yıl kadar önce

1 Jean-Pierre Brun, Le vin et l' huile dans la Méditerranée antique. Viticulture et procédés de fabrication, Paris 2003, p. 127

2 Fernand Braudel, La Méditerrannée et le monde méditerranéen à l'époque de Philippe II, 3rd. edition, Paris 1976, vol.1, p.212 [Türkçe çev.] 1993, II. Pelipe Döneminde Akdeniz ve Akdeniz Dünyası, çev. Mehmet Ali Kılıçbay, Ankara, İmge Yay. 
evcilleştirmiş olsa da uzun bir dönem, pek çok Akdeniz ülkesinde zeytinyağının beslenmede kullanılması ender görülüyordu. Bunun nedeni, insanlar evcilleştirilmiş zeytin ağaçlarının [Olea europea L. Sativa] yanında oleasterlerin [Olea europea L. Oleaster] meyvelerini toplamaya devam ederlerken, birçok yerde zeytin ağacının az verimli olmasıdır. Ayrıca oleasterler evcilleştirilmiş zeytinlerden daha az ürün veriyordu. 0 zamanki teknolojik düzeyi düşünürsek, zeytinin ezilip posanın preslenmesi önemli bir insan gücü ve malzeme yatırımı talep ediyordu. Ona kıyasla, hayvani yağlar ve tahıllardan elde edilen yağları elde etmenin daha kolay olması, bunların yemek pişirmekte daha yaygın kullanılmasının nedeniydi. Ne var ki tuz ve sirkeyle, salamura edilmiş zeytinlerin tüketiminin yaygın olduğu görülüyordu. Bronz Çağ'ın Ege uygarlıklarında durum kesinlikle böyleydi. Girit ve Pylos saray arşivlerinde, sofralık zeytinler ile parfüm ve kozmetik imalatında kullanılmak üzere ayrılan zeytinlerin envanterine rastladık. ${ }^{3}$ Homeros destanlarının kahramanlarının da vücutlarına bakım için zeytinyağı kullandıkları görülüyordu.

Teknoloji, yani zeytinin preslenmesi için gereken aletler, zeytin kültürünü ve meyvelerinin tüketilmesini etkileyen bir faktördür. Bir diğer faktör kategorisi, kırsal bölgelerdeki mülkiyet ilişkisidir. Antik efsaneye göre, Atina şehri adını Poseidon'la girdiği yarışmayı Atinalılara zeytin ağacı sunarak kazanan tanrıça Athena'dan almıştı; Atinalılar deniz tanrısının sunduğu atları değil, zeytini tercih etmişlerdi. Edebi ve epigrafik kaynaklar, antik Atinalıların ekonomisi ve dini ayinleri için zeytinin önemini onaylıyor. Ancak yüzyıllar sonra, Romalılar döneminde yazan Plutarkhos'a göre, Solon yasaları zeytinyağını yiyecek maddeleri ihracatına konan genel yasaktan muaf tutmuştu. ${ }^{4}$ Bununla birlikte, Atina'da yağ ihracatında başı çeken, gimnazyumlarda vücut bakımı ve parfüm imalatında kullanılan yağlardı. Öyle anlaşılıyor ki, yüzyıllar boyu bu kaliteli yağın ihracata dönük ticareti, dört yılda bir tanrıça Athena onuruna yapılan Pan-Atina oyunlarının galiplerinin elindeydi. ${ }^{5}$ Pan-Atina oyunlarında, çeşitli atletizm yarışmalarında galiplere, ödül olarak her biri yaklaşık kırk litre kapasiteye sahip özel şekilli ve süslemeli amforalar verilirdi. Arkeologların epigrafik kanıtlara dayalı değişik tahminlerine göre, galiplere ödül olarak verilen zeytinyağının toplam miktarı kırkı iki ya da yetmiş iki tonu bulurdu. ${ }^{6}$ Kırım'dan,

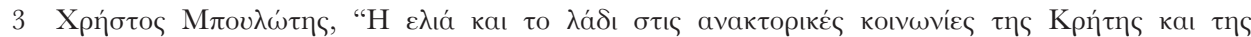

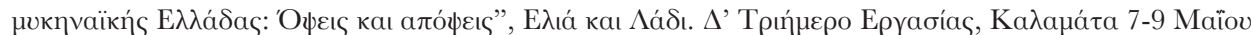
1993, [Christos Boulotis, "Olive and Olive Oil in the Palatial Societies of Crete and Mycenian Greece" in Olive and Olive Oil, 4th Threeday Workshop, Kalamata May 7-9, 1993, Athens 1993, pp. 19-58]

4 Lin Foxhall, Olive Cultivation in Ancient Greece: Seeking the Ancient Economy, Oxford, 2007, p. 17

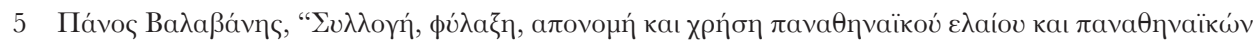
ацфорє́ $\omega v "$ "Panos Valavanis, Collecting, storing, awarding and using Panathinaic oil and Panathinaic

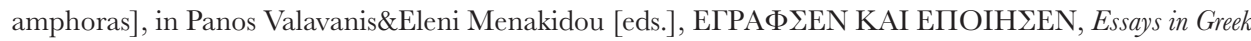
Pottery and Iconography in Honour of Professor Michalis Tiverios, Thessaloniki 2014, p. 378-379

6 Panos Valavanis, supra and Lin Foxhall, op.cit., p.117 
Afrika'daki Kirene ve Batı'daki Marsilya'ya kadar Akdeniz dünyasının farklı alanlarında arkeolojik kazılarda bulunan Pan-Atina amforaları, çok miktarda zeytinyağının ihraç edildiğine işaret eder.

Pan-Atina yağı, muhtemelen Akropolis'teki ilk zeytin ağacından türemiş kutsal zeytin ağaçları, moriae'den üretilmişti. Moriae, gerek slk zeytinlikler, gerekse özel mülklerdeki tek tek ağaçlar şeklinde Attika'nın her tarafına yayılmıştı. Ne var ki, arkeoloji Klasik Çağ'da Attika kırsalında zeytinyağı preslerinin varlığıyla ilgili kanıtları henüz sunmuş değildir. Günümüzün tarihçileri, bu eksikliği kendi ailelerinin kendi kendine yeterliliğini sağlama almaya çalışan küçük çiftçilerin ağır basmasıyla açıklıyorlar. Onlar tarlalarının kenarlarına diğer meyve ağaçlarıyla birlikte, bazı zeytin ağaçları da dikiyorlardı. Zeytin ağaçlarından iyi verim almadıkları düşünülürse, klasik Atinalı çiftçilerin büyük presleme tesislerine yatırım yapmakta hiçbir çıkarları yoktu. Zeytinlerini geriye hiç iz kalmamış olan ilkel araçlarla işlemişlerdi. Belki de Attika'daki birkaç büyük malikânede presler vardı. ${ }^{7}$

Zeytinyağı elde etme teknolojisinde önemli bir adım, İö. IV. yüzyıl sonunda, Kuzey Yunanistan'da zeytinyağı işleme tesislerinin verimliliğini büyük ölçüde yükselten yuvarlak kırma teknesinin bulunmasıyla atıldı. Yeni tip zeytin kırma teknesinin kullanılmasının, Makedonyalı üst sınıfların büyük malikânelerinin ortaya çıkışıyla ilgisi olduğu düşünülmektedir. ${ }^{8}$ Bana kalırsa, bu yeniliğin bir başka uyarıcısı, Helenistik dönemin büyük şehirlerinin gelişmesiydi. İskenderiye, Antakya ve o dönemin diğer büyük kent merkezleri, eski dönemlerin küçük şehir-devletlerinde uygulanan yöntemler kullanılarak ikmal sağlanamayacak kadar büyüktü. Yemek, vücut bakımı ve Helenistik çağın varlıklı yurttaşlarının evlerinin aydınlatılmasında tüketilen zeytinyağı miktarı, yaklaşık olarak zengin bir Atinalı ailenin ihtiyaç duyduğu miktara eşitti: Yani, yılda iki yüz-üç yüz otuz kilo. ${ }^{9}$ Yeni zeytin kırma teknesi trapetum, İ.ö. II. yüzyıldan başlayarak Roma döneminde yaygınlaşmıştır. Akdeniz havzasının birçok alanındaki arkeolojik bulgular, Latin yazarların tasvirlerini teyit ediyor. Onların zamanında, gelişerek yarım milyona ulaşan Roma gibi bir şehre gıda arzı lojistiği karmaşık bir girişimdi. İmparatorluk başkentine gemilerle nakledilen yağın başlıca tedarikçileri İspanya ve Kuzey Afrika'ydı. Suriye, Geç Antik Çağ'da Antakya, İskenderiye ve Konstantinopolis yağının büyük toptancısıydı. Bazı arkeologlar, Suriye'nin Cebel Zaviye gibi bazı bölgelerinin zeytinyağı için zeytin mono kültürüne ayrıldığına inanirlar. ${ }^{10}$

7 Lin Foxhall, op.cit., pp. 202-206

8 Lin Foxhall, op.cit., pp.140, 151-152 See another possible rotary crushing mill in ancient Macedonia

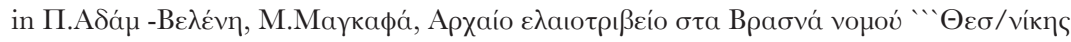

9 Lin Foxhall, op.cit., pp. 86.

10 Georges Tchalenko, Villages antiques de la Syrie du Nord. Le massif de Belus à l'époque romaine, 2 vol. Paris 
Zeytinyağı tüketimiyle ilgili dördüncü bir faktörler dizisi vardır: Dinsel emirler ve sembolik anlamlar. Orta Çağ'ın sonlarına doğru, İspanya'da Hıristiyanlar hayvani yağlarla, tocino ile yemek yaparken, Yahudi komşuları zeytinyağını tercih ederlerdi. Hıristiyanların ve Yahudilerin yemek alışkanlıkları arasındaki aynı kopukluk, Orta Çağ Sicilya'sında da varlığını sürdürdü. ${ }^{11}$ XV. yüzyıl İspanya'sında Kutsal Engizisyon'un Conversos [t.ç.n., Dönmeler, Yahudilikten ayrılıp Katolikliği seçenler] evlerinde zeytinyağı tüketimini gizli Musevilik olarak yorumlaması sürpriz sayılmamalı. ${ }^{12}$ Ancak, ben dinsel kopukluğun sadece alt sınıfları ilgilendirdiğinden şüpheleniyorum. Çünkü iki yüzyıl sonra, Fransa'nın Madrid Büyükelçisi Duke de Saint Simon, alt sınıfların kullandığı yağın kalitesiz olduğunu, oysa aristokrasinin kendi malikânelerinde üretilen çok kaliteli zeytinyağını tükettiğini belirtmişti. Saint Simon'un anlattığı bir başka olayda, sınıf tekrar karşımıza çıkıyor: Akşam yemeğinde, bir tas içindeki zeytinleri genelde Fransız soyluları gibi küçük bir kaşık yerine, çatalla yemeğe çalışan bir sahtekâr, kendisinin aşağı toplumsal tabakalardan geldiğini belli etmişti. ${ }^{13}$ Bugün, dini aidiyetleri ve toplumsal kökenlerinden bağımsız olarak, tüm İspanyollar yemeklerinde zeytinyağı kullanırlar. Ancak düşük gelir grubundakiler hilelere daha çok maruz kalırlar; ${ }^{14}$ çünkü çok sık hileli satılan ucuz yağları almak zorunda kalırlar. 1981 yılında, resmi verilere göre, hileli kolza yağı tükettikten sonra üç yüz elli kişi ölmüş ve yaklaşık yirmi bin kişi hastalanmıştı. ${ }^{15}$

Zeytinyağı tarihinde, teknoloji, mülkiyet ilişkileri ve sembolik anlamların karşılıklı etkisi, modern zamanlarda da sürmektedir. Ne var ki, Eski Çağ tarihçileri ve özellikle de arkeologlar, bu konular üzerinde yoğun araştırmalar yaparlarken, modern ve özellikle yaşadığımız dönemle ilgilenen meslektaşları, zeytinyağının tarihindeki birçok yönü boşlukta bırakmışlardır. Yazımın geri kalanında, Girit Adası örneğinde zeytinyağının tarihselliğini göstermeyi deneyeceğim.

Girit'te zeytinyağının modern tarihi, XVII. yüzyllın ikinci yarısında adanın Osmanlılarca fethedilmesiyle başlar. Adanın eski hâkimleri Venedikliler zamanında, adanın başlıca ihraç ürünü şaraptı. Batı Avrupa'da mükemmel bir ün kazanan Girit'in tatlı şarapları,

1953. See also the book review by André Chastagnol in Annales. Economies, Societés, Civilisations, vol. 13 [1958] pp. 375-378. The opinion of Tchalenko has been criticized by Georges Tate in Georges Tate, Maamoun Abdulkarim, Gérard Charpentier, Catherine Duvette et Claudine Piatton, Sergilla, Village d' Apamène, vol. 1, Beyrouth 2013 p. 26.

11 Henri Bresc, Arabes de langue fuifs de religion, Paris 2001, p. 74.

12 Jacqueline Guiral Hadziiossif, Meurtre dans la cathédrale, Paris 2012, p. 215.

13 Saint Simon, Mémoires. Anthologie, Le livre de Poche, Paris 2007, pp. 899-901, 1321-1322.

14 cadenaser.com/programa/2012/10/28/ser_consumidor/1351427840_002916.html, retrieved 12.12.2015.

15 www.elblogdelasalud.es/aceite-de-colza-intoxicacion-espana-1981/ retrieved 12.12.2015. 
İngiltere ve Flanders gibi uzak ülkelerde bile satılıyordu. Girit, XIV. yüzyılda, kötü hasat dönemlerinde Peloponnes'ten zeytinyağı ithal etmiş olabilir. ${ }^{16}$ Zeytincilik, Venedik egemenliğinin son döneminde yaygınlaşmış olmakla birlikte, Osmanlılar zamanında sektör hem nicel, hem de nitel bir sıçrama yapmıştı. Eldeki tüm göstergeler, zeytinyağının hem üretiminde, hem de ihracatında XVII. yüzyıldan XVIII. yüzyıla geçilirken önemli bir artış yaşandığına işaret ediyor. Girit'in tarımsal ihraç ürünleri sepetinde, şarabın yerini zeytinyağına bırakmasının zamanlaması ve nedenleri, tarihçiler arasında hâlâ tartışılıyor. Bağcılığın çökmesinin sorumluluğunu, siyasal değişim ve İslam’ın dinsel yasaklarının getirdiği ticaret şebekelerinin bozulmasına yol açan Osmanlı fethine bağlayanlar var. Onlara karşı çıkanlarsa Girit şaraplarının daha Venedikliler döneminde ihraç pazarlarını kaybetmekte ve daha Osmanlılar gelmeden zeytinlik alanların genişlemekte olduğunu öne sürüyorlar. ${ }^{17}$ Bana kalırsa, her iki taraf tarımsal ekonominin önemli iki faktörünü ihmal ediyor: Emeğe erişim ve mülkiyet ilişkileri. Her biri farklı emek girdileri gerektirdiğinden, zeytinlikler ve bağlar basitçe karşılıklı dönüştürülebilir plantasyonlar değildir. Ersin Gülsoy, iki üretim süreci arasındaki farklılıklara işaret ederken, bunları sadece beceri ve teknik sorun olarak düşünür. ${ }^{18}$ Gerçekte farklılıklar çok daha derindir. Bağcılık önemli oranda daha emek yoğundur ve yıl içinde birkaç kez gerekli işgücünün seferber edilmesinde uygun ekonomik ve toplumsal sinırlamalara tabidir. Asmalar için toprağın kazılması, budama işlemi, gübreleme ve hasat için gerekli işgücünü bulmak, Osmanlı fethinden sonra iki nedenle zorlaşmıştı. İlki, nüfustaki genel azalma, ikincisi de soylu toprak sahiplerinin köylüler üzerindeki baskısının ortadan kalkmasıydı. Üst sınıfların önemli bir kısmı, Venedik devletinin diğer yerlerine sığınmak için adadan ayrıldıkları gibi, öyle görünüyor ki Osmanlı rejimi köylülere ekecekleri ürünü seçmekte daha büyük özgürlük tanımıştı. Köylüler de bu özgürlükten yararlanarak kendi kendine yeten ekonomiye yönelmiş ve ticari ürünleri terk etmişlerdi. XVIII. yüzyılın ilk yarısından gelen çeşitli raporlara göre, Girit'te tahıl boldu. Oysa Venediklilerin egemenliği sırasında büyük toprak sahiplerinin otoritelerin tahıl ekimi için daha kârlı olan şarap üretimini terk etme yönündeki baskılarına direnmeleri nedeniyle, tahıl kıtlığı yaşanıyordu. Osmanlılar zamanında,

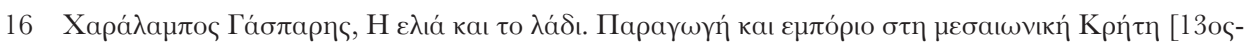

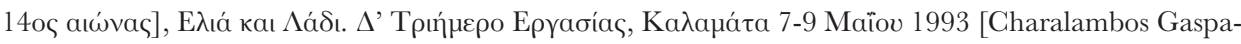
ris, Olive and oil. Production and Trade in Medieval Crete, thirteenth-fortenth centuries in Olive and Olive Oil, 4th Threeday Workshop, Kalamata May 7-9, 1993, Athens 1993, pp. 151-158.

17 Molly Greene, A Shared World. Christians and Muslims in the Early Modern Mediterranean, Princeton, 2000, pp. 110-140.

18 Ersin Gülsoy, "The Legal and Economic Status of the Reaya of Crete During Ottoman Rule [16451670]" in Antonis Anastasopoulos, The Eastern Mediterranean Under Ottoman Rule: Crete, 1645-1840, p. 66. Türkçe çeviri: 2004, Ersin Gülsoy, Girit'in Fethi ve Osmanl İdaresinin Kurulması [1645-1670], İstanbul, Tarih ve Tabiat Vakfi Yay., 383 sayfa.
} 
köylüler sadece ailelerinin ihtiyaçlarını karşılayacak birkaç zeytin ağacı dikerlerdi. Büyük zeytinlikler büyük toprak sahiplerine, Osmanlı görevlilerine ya da dini vakıflara aitti. Bu mülkler artan zeytinyağı ihracatının büyük bölümünü karşllıyorlardı. ${ }^{19}$

Osmanlı Girit'inin zeytin ekonomisindeki yeni unsur, adanın başlıca şehirlerindeki sabun imalathanelerinin kurulmasıydı. Kandiye'de kurulan ilk sabun imalathanesinin bir Fransız tüccarına ait olduğu söylenir. Tüccar çok geçmeden, 1699 yılında iflas etmiş, ama aynı zamanda büyük zeytinliklerin sahipleri de olan yerel Osmanlı görevlileri onun örneğini izlemişti. XVIII. yüzyılın ortalarına doğru, sabun imalathaneleri ortalama zeytinyağı üretiminin yaklaşlk \%22'sini yutuyordu. ${ }^{20}$

Zeytinyağının işlenmesine dönük hamle, o zamana kadar sırf gıda maddeleri ve hammaddeler ihraç edip mamul madde ithal etmiş olan Girit ekonomisinin sömürge niteliğinden önemli bir kopuşu temsil ediyordu. ${ }^{21}$ Ne var ki, bu kurumları 'sanayi' olarak adlandırmak abartı olur. Bunlar mekanik güç kullanmıyorlardı; aletleri ilkeldi ve mevsimlik temelde işliyorlardı. Ayrıca, yerel görevliler ve yeniçeri ocaklarının müdahil oldukları bu işletmelerin mülkiyet yapısı, sanayi sektöründeki sermaye birikimine uygun değildi. Girit Üniversitesi'ne son zamanlarda verilen bir doktora tezi, Osmanlı Girit'i ekonomisinin oligarşik bir yapısı olduğunu gösterir. Birkaç büyük ailenin üyeleri, eşzamanlı olarak büyük toprak sahipleri, mültezim ve sabun imalatçılarıdır. Aynı zamanda, genelde girişimlerini finanse eden yerel yeniçeri ocaklarıyla da iỵi ilişkiler sürdürdükleri gibi, İstanbul ve İzmir tüccarlarıyla da ilişkilerini koruyorlardı. ${ }^{22}$

Ne yazık ki, arkeologların çok iyi belgeledikleri Antik Çağ ve Orta Çağ zeytin presleriyle ilgili bilgilerimiz, modern zamanların zeytinyağı üretimi ve işlemesinin teknik özellikleriyle ilgili bilgilerimizden fazla. Kandiye'nin ilk sabun imalathanesinin Fransızlar tarafından kurulmuş olması, Batı Avrupa'dan Doğu'ya bir teknoloji transferiyle karşı karşıya olduğumuz anlamına gelmiyor. Sabun üretim teknolojisi Osmanlı İmparatorluğu'nda iyi biliniyordu; çünkü önemli sabun imalathaneleri orada, özellikle de Osmanlı Suriye'sinde zaten faaldi. ${ }^{23}$ Eğer bu Girit işletmelerini geniş Osmanlı ve Akdeniz ortamına yerleştirirsek, o zaman XVII. ve XVIII. yüzyıllarda sabun imalatındaki gelişmenin, genel pazarın

19 Yannis Spiropoulos, Social, Administrative, Economic and Political Functions of the Ottoman Army: thefanissaries of Crete, 1750-1826, unpublished Ph.D. dissertation, University of Crete, Rethymno, 2014.

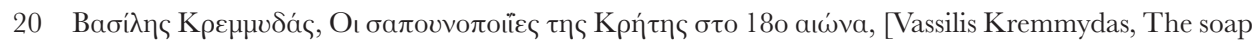
manufactures of Crete during the eighteenth century], Athens 1974, p.18.

21 V. Kremmydas, op.cit. pp. 64-69.

22 Yannis Spiropoulos, op.cit.,

23 André Raymond, "Alep à l' époque ottoman XVIe-XIX siècles", Revue du Monde Musulman et de la Méditerranée, 62 [1991], pp. 93-109. 
sürüklediği bir görüngü olduğunu anlayabiliriz. Girit sabun imalathaneleri, sadece Halep ve Mora'daki [Koron] sabun imalathanelerinin değil, aynı zamanda Provence'ın büyük işletmeleriyle de çağdaştı. Bu dönüşümün temelinde, hem Fransa, hem de Osmanlı İmparatorluğu'ndaki tekstil manüfaktürleri yatıyordu. Girit’te üretilen sabun, İstanbul'da satılır, oradan İmparatorluğun diğer yerlerine yeniden dağıtılırdı. Ne yazık ki, bu iç ağlar konusunda çok az şey biliyoruz.

Napolyon savaşlarının bitmesinden sonra, bu özel imalat dalı daha iỵi örgütlenmiş Batı Avrupa sanayiinin baskısıyla geriledi. Marsilya sabun sanayileri, Fransız kimyagerlerinin bilimsel buluşları ve denizaşırı topraklardan ithal edilen daha ucuz bitkisel yağların kullanılmasıyla, Doğu Akdeniz manüfaktürleri karşısında rekabetçi bir avantaj elde etti. 1817 yılında, Fransız ve Girit ürünleri arasındaki kalite farkı o kadar önemli hale gelmişti ki Selanik'in eski Fransız konsolosu ve Fransız-Osmanlı ticareti uzmanı Félix Beaujour, Marsilya sabun sanayilerinin hammadde olarak Girit sabununu kullanmasını önerdi. ${ }^{24}$ Hem bilgi, hem de sermaye eksikliğinden, yeni teknoloji Doğu Akdeniz manüfaktürlerine girmedi. Ancak XIX. yüzyıl sonuna doğru, Doğu Akdeniz'in bazı noktalarında yeni sabun sanayiinin başlamasına imkân verecek yeterli bilgi ve sermaye ortaya çıktı.

Bu gibi noktalardan biri de o zaman Osmanlı İmparatorluğu'nun parçası olan Midilli [Lesbos] adasıydı. Midilli'de, önemli zeytinyağı üretimi modern zeytin işleme tesisleri ve sabun sanayileri için gereken insan ve para sermayeyi seferber etme peşinde koşan ve bunu yapabilecek durumda olan dinamik bir burjuvaziyle örtüşmüştü. ${ }^{25}$ Birçok örnekte, fabrikalar zeytinlik, zeytinyağı presi ve sabun fabrikasından oluşan dikey entegre işletmelerin parçasıydı. Bu işletmelerde, bazı örneklerde bitişik tahıl değirmeni olarak da hizmet eden bir buhar makinesi kullanılırdı. Sanayi tipi, buhar gücü kullanılan, yağ işleme tesislerinin ortaya çıkışı, tarım sektöründeki toplumsal ilişkilerin tam dönüşümüyle birlikte görülmüştü. Buhar gücü kullanan yağ preslerinin kurucularının çoğu, yurtdışında, İstanbul'da ya da değişik Karadeniz limanlarında ticaret yaparak zenginleşmiş tüccarlardı. Sanayi tipi yağ presi, onlar için tarım kredilerinin yanında köylüler üzerindeki ekonomik egemenliğin ek bir aracını temsil ediyordu. Böylece yağ işlemenin makineleşmesi, adada sermaye birikimini hızlandırmıştı. Bu yolla, tüccarlar yerel zeytin ekonomisine egemen olabilecek ve kendi koşullarını küçük üreticilere dayatabilecek bir konuma gelmişlerdi. Midilli, 1912 yılında Yunan devletine katıldığında, buhar gücüyle çalışan yüz on üç yağ presine sahipti. Bu, bütün ülkede buhar gücüyle işleyen yağ işleme tesislerinin en

24 V. Kremmydas, op.cit., p. 43.

25 Evridiki Sifneos, "On Entrepreneurs and Entrepreneurship of the Olive-Oil in the Aegean: The Case of Lesvos Island", The Historical Reviere, vol.1 [2004], pp. 245-273. 
yüksek yoğunluğuydu. ${ }^{26}$

Tam karşıdaki Asya kıyısında yer alan Ayvalık’ta benzer bir gelişme yaşandı. 1864 yılında, İngiliz konsolosu, Ayvalık ekonomisinin geri ve çok parçalanmış olduğunu söylemişti: “Ayvalık’ın nüfusu yaklaşık otuz dört bindir. Çok az Avrupalı var. Sakinlerinin geri kalanı zeytin işleme ve sabun imalatıyla uğraşıyor. Doksan yedi yağ değirmeni, otuz sabun imalathanesi var. Gerekli tarım aletleri, çırçır makineleri ve yağ preslerine duyulan çok fazla ihtiyaç duyulduğu halde, yerli halkı eski sistemlerini değiştirmeye ikna etmek zor." 27

Gerçekten de Ayvalık’ın 'yerlileri' değişime az direndiklerini gösterdiler. Yukarıdaki konsolos raporundan yirmi yıl kadar sonra, buhar gücüyle çalışan yağ presi faaliyete geçmişti bile. Üretim araçlarının modernizasyonu ve beraberinde getirdiği ekonomik güç yoğunlaşması, var olan toplumsal karşıtlıkları öne çıkarmıştı. Midilli'de, pek çok Hıristiyan toplulukta zengin tüccarlarla yoksul köylüler arasında çatışmalar dinmiyordu. ${ }^{28}$ Üç köylü topluluğunda, Agia Paraskevi, Agiassos ve Mantamado'da toplumsal karşıtlıklar, belediyenin buhar gücüyle çalışan bir yağ presi kurmasıyla sonuçlanmıştı. ${ }^{29}$

Yağ işleme sanayinin makineleşmesi, ekonominin tarım ve sanayi sektörleri arasında yeni bağlar yaratmıştı. Yunanistan'da Pire'deki ve Osmanlı İmparatorluğu'nda İzmir'deki motor sanayileri, Ege çevresindeki bazı zeytinyağı preslerine ve sabun fabrikalarına makine parçaları ya da anahtar teslim ediyorlardı. Midilli'de, tesislerin çoğunluğu İzmir'deki makine işletmeleri tarafından inşa edilmişti. Örneğin, Agia Paraskevi'nin topluluğunun 'kamusal makinesi', İzmir'in Dimosthenis Isigonis makine şirketi tarafından yapılmıştı. Şimdi Midilli Yağ İşleme Sanayileri Müzesi olan eski komünal yağ işleme tesisini hâlâ hayranlıkla izliyoruz. Urla yakınlarındaki Nohutalan köyündeki Köstem Müzesi'nde, Ayvalık'taki bir yağ değirmeni için İzmir'in Rankin\&Demas şirketinin ürettiği buhar gücüyle çalışan bir yağ işleme tesisinin tamamı sergilenmektedir. Aynı müzede, 1886 yılında Ödemiş’teki bir yağ değirmeni için Yunanistan'ın Pire şehri merkezli makine işletmesi, McDowall\&Barbour'un ürettiği benzer bir tesis de görülebilir. Ben, bu makine ve alet üreticilerinin Ege'nin her iki yakasında da birleşik çok disiplinli araştırmanın konusu olmayı hak ettiklerini düşünüyorum.

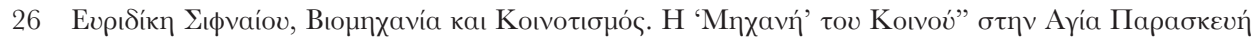
$\Lambda \varepsilon \dot{\sigma} \sigma \beta \mathrm{ov}$, [Evridiki Sifneos, Industry and Community. The 'Public Engine' in Agia Paraskevi of Lesbos], Athens, 2007, p. 8.

27 Foreign Office, Annual series, Aivali August 5, 1865.

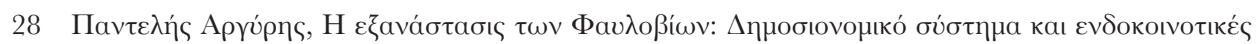

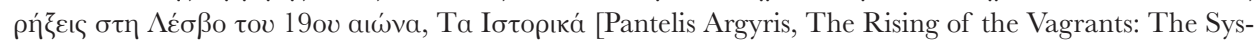
tem of Communal Finances and Intracommunal Conflicts], Ta Istorika, No 16, 1992, pp. 49-64

29 Evridiki Sifneos, op.cit., pp. 26-29. 
Zeytin kullanımındaki yeni adımın arkasında, teknoloji ve yeni pazarlar vardır. Kimyasal ve mekanik yöntemlerle, zeytin çekirdeklerinin içerdiği atık yağı çıkarıp sabun ya da gres yağı olarak kullanmak mümkün olmuştu. Bu sanayide kullanılan üretim süreci gibi, tesisler de alelade yağ presinden çok daha gelişmiş ve pahalı olduğundan, rafinerinin kurulması gıda işleme sanayiinde sermayenin yoğunlaşması yönünde büyük bir adımı temsil eder. Günümüz tahminlerine göre, bir rafineri elli-yüz yağ presinin çekirdeklerini işleyebilir. ${ }^{30}$ Bu sanayi dalı, Doğu Akdeniz'de 1870'lerde başladıysa da tarihi büyük ölçüde karanlıkta kalıyor. ${ }^{31}$ İki savaş arası dönemde yayılan zeytinyağı rafinerileri, çok sık olarak kaliteli yağları taklit etmek için kullanılan rafine zeytinyağı denilen ucuz çeşidi üretiyorlardı. Bu gelişme, artan kentli nüfusun ve özellikle de düşük gelirli tabakanın ihtiyaçlarını karşılamaya dönüktü. Piyasanın bu kesiminde sömürü, en başından beri sanayi hileleri ve çevre kirliliğinin yol açtığı sorunlarla birlikteydi. 1929 krizi sonrasında, tarım ürünlerindeki fiyat düşüşleri bu sermaye-yoğun dalı çok fena vurdu. Bankacıllk sektörü krize bağımsız işletmelerin büyük girişimler halinde birleşmesini teşvik ederek cevap verdi. Bu sanayi dalının tarihini son derece ilginç kılan şey, kapitalist karakterinin daha vurgulu olarak açığa çıkmasıdır. Aynı zamanda, tarihçilerin şimdiye kadar zeytinyağı rafinelerinin tarihini ihmal etmiş olmalarının nedenleriyle ilgili ek bir tarihsel sorunla da karşı karşıyayız. Bu ihmal, tarihçilerin zihinlerinde bu sanayinin ekonomik önemini dengeleyen sembolik nedenlerle açıklama eğilimi vardır. Rafine yağ, natürel zeytinyağından daha az saftır ve üretiminde kullanılan kimyasal yöntemler, mekanik presle karşılaştırıldığında zeytinin özgün natürel durumundan daha uzaktır.

Akdeniz çevresindeki zeytin ağaçlarının tarihindeki son evre, 1958'de Avrupa Ekonomik Topluluğu'nun kuruluşu ve Ortak Tarım Politikası'nın yürürlüğe konulması başladı. Zeytinyağı, Ortak Tarım Politikası'nın sübvanse ettiği tarım ürünleri arasındaydı. Bu politikadan kârlı çıkan ilk ülke İtalya, sonra Yunanistan olurken, İspanya ve Portekiz kulübe 1986'da katıldı. Yunanistan'da, bu ödeme transferleri zeytin üreticileri için kısa bir mali rahatlık dönemini müjdelerken, zeytin ağacı ekili alanların hâlâ süren genişleme sürecini başlattı. Aynı zamanda, Avrupa'nın yapısal fonları zeytinyağı preslerinin sahiplerinin ekipmanlarını modernize etmelerine yardımcı oldu. Bu politikaların sonuçları henüz ciddi olarak araştırılmamıştır. Ancak bazı neticeleri kolayca seçebiliriz: Birincisi, kültür yöntemlerinde önemli iyileşme olmamıştır. İkincisi, Avrupa'dan gelen paranın önemli bir kısmı, ya emlak yatırımları biçimlerinde ya da çoğunlukla ithal edilen mamul malların

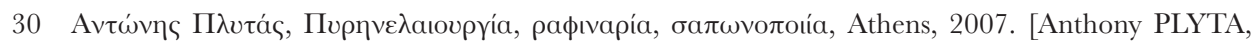
Pyrinelaiourgia, refinery, soap, Athens, 2007].

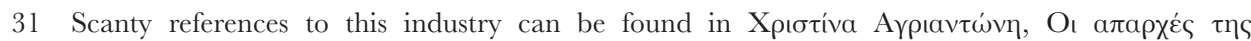

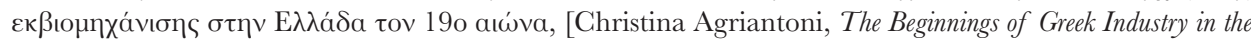
Nineteenth Century], Athens 1986, pp. 127, 242-243. 
artan tüketimi biçiminde, kentsel sektöre yeniden yönlendirilmişti. Üçüncüsü, birçok şehir sakini Avrupa sübvansiyonlarından faydalanmak için ya yeni zeytinlikler yaratmış, ya da mevcut zeytinlikleri satın almışlardı. Dördüncüsü, yağ preslerinde yemeklik zeytinyağı kalitesinde önemli bir gelişmeye yol açan yoğun bir modernizasyon yaşanmıştı. Ancak modern sanayi ekipmanlarının diğer Avrupa Birliği ülkelerinden ithal edilmesi nedeniyle, Yunanistan'da tarım ve yerel makine sektörü arasındaki bağ kopmuştu.

Bugün bir paradoksla karşı karşıyayız. Avrupa sübvansiyonları ciddi olarak tırpanlanmış ve çoğu zeytin üreticisi zararına üretim yapmaya başlamıştır. Bu olguya karşın, zeytinlikler yayılıyor ve insanlar kendi zeytinliklerine sımsıkı sarllıyorlar. Bu paradoksal durumu, şu an için mali kaygılardan daha güçlü olduğu kanıtlanan sembolik faktörler aracıllğıyla açıklayabiliriz. Böylesi uzun bir tarihten sonra, zeytin ağaçları ve zeytinyağı bir bakıma insanlarla aynı tabiata sahip olmuştur. İnsanın kendi zeytinini hasat etmesi ve kendi zeytinyağını üretmesi, yanıltıcı bir toprak sahibi toplumsal statüsünü yeniden onayladığı görülen bir çeşit tatmin duygusu yaratır. Bu, aynı zamanda bir güvenlik duygusu da yaratır; çünkü birçok ailede II. Dünya Savaşı sırasında Alman işgalinin anıları hâlâ tazedir. Bu dönemde, fiyatlar zeytinyağı miktarına sabitlenmiş ve hatta ekonomiyi yönetenler zeytinyağı fiyatını enflasyon oranını tahmin etmekte kullanmışlardı. Güvenlik duygusunun bir başka yanı daha vardır. Birçok insan bugün piyasada görülen yüksek kaliteli markalara karşın, sınai zeytinyağına içgüdüsel bir güvensizlik besler. Kendi zeytinyağlarını tüketerek, insanlar kaliteli zeytinyağı yediklerinden emin olabilirler.

Kolektif düzeyde, bireylerin duygularının irrasyonelliği, zeytinyağının baş köşeye kurulduğu Akdeniz diyetinin teşvik edilmesi gibi açıkça rasyonel bir politikayı yaratır. Keşke tüm Kuzey Avrupalılar, tüm Kuzey Amerikalılar ve tüm Çinliler hayvani ve bitkisel yağları tüketmek yerine zeytinyağı tüketmeyi kabul etseler ne güzel olur. 0 zaman Akdeniz yeniden dünyanın merkezi haline gelirdi. 


\section{Erken Modern Osmanlı İmparatorluğu'nda Zeytin ve Zeytinyağı Tüketimi}

\section{Prof. Dr. Suraiya FAROQHI}

İstanbul Bilgi Üniversitesi Öğretim Üyesi

Klasik Antik Çağ'da, Akdeniz tarımının başlıca ürünleri zeytin dışında tahıl, çoğunlukla buğday, arpa, üzüm ve üzümden imal edilen şaraptı. Bu yüzden, İstanbul'un eskiden Theodosius hanedanından kalma limanı olan Yenikapı mahallesinde yapılan kazılarda çıkartılan Bizans gemilerindeki amforalarda bol miktarda şarap dışında, önemli miktarlarda zeytin ve zeytinyağı taşınmış olmalıydı.

İslamiyet'in gelişiyle, üzümün eski önemini yitirdiği sanılabilir. Oysa en azından Osmanlı dünyasında, bu hiç de doğru değildi. Çünkü tatlılar, Osmanlı mutfağında önemli bir role sahipti. Şeker çok ender ve pahalı olduğundan, bal kolay bulunmadığından, tatlandırıCl olarak kuru üzüm ve pekmez yaygın olarak kullanılırdı. Sofralık üzümün bulunduğu yerlerde, bu meyveler taze de yenirdi. XVI. yüzyıl vergi kayıtları, bağlar, meyve bahçeleri ve bahçelerden alınan bir vergi olan resm-i bağ'ın pek çok kasaba ve köyde standart olduğunu gösterir.

\section{Az Zeytinli Bir Mutfak}

Tersine, erken Osmanlı döneminde zeytinin çok az göze çarptığı görülüyor; nedenleri tartışılmış olmakla birlikte, kesin kanıtlara sahip değiliz. Neden her neyse, erken Osmanlı döneminden, belki daha öncesinden başlayarak sadeyağ, yenilebilir yağların tercih edilen türü olmuştu. Nicolas Trépanier'nin, Orta Çağ Anadolu yemek kültürüyle ilgili son araştırmasında, zeytine bir tek yerde atıf yapması yine de semboliktir. ${ }^{1}$ Erken modern Osmanlı sultanlarına gelince, onların saray mutfaklarında tereyağına kıyasla çok mütevazi miktarlarda da olsa zeytin ve zeytinyağı yiyecek olarak kullanılırdı. ${ }^{2}$

Merkezi Osmanlı topraklarında sınırlı zeytin tüketimine dair gözlemlere oldukça sık rastlanıyordu. Faruk Doğan'ın, çok öğretici araştırmasında isabetli yorumlar bulmuştum. ${ }^{3}$ Zeytinyağının, özellikle kilisenin hayvani yağların yasaklandığı, farklı günlerde oruç

1 Arif Bilgin, Osmanl Saray Mutfağ [1453-1650], İstanbul: Kitabevi, 2004, s. 203.

2 Nicolas Trépanier, Foodways and Daily Life in Medieval Anatolia: A New Social History, Austin/Texas: Texas University Press, 2014, s. 77.

3 Faruk Doğan, "Osmanlı Devletinde Zeytinyağı Üretimi ve Tüketimi," Türk Mutfağı içinde, yay. haz. Arif Bilgin ve Özge Samancı, Ankara: T.C. Kültür ve Turizm Bakanlığı, 2008, s. 231-242. Doğan, 1800'ler 1900'lerin başıyla ilgilenir. 
tutmayı emrettiği Ortodokslar tarafından tercih edildiğini unutmayalım. Marianna Yerasimos'un söylediği gibi, bir gayrimüslim cemaatle özdeşleşmesi, belki de Müslümanlar arasında zeytinyağının prestijini azaltmıştı. ${ }^{4}$ Padişahın, Müslüman tebaalarının XVII. yüzyıldan itibaren iyi belgelenmiş olan etli dolmaya ilaveten, zeytinyağıyla pişirilen soğuk sebzeleri nasıl ve ne zaman tüketmeye başladıkları konusunda bilgimiz çok az. Belki de bu dönüm noktası, 1800'lerde geçilmişti ama kesin emin olamayı.

Gelgelelim, XVIII. yüzyılda zeytinyağının Ege kıyılarından İstanbul'a sevk edilen sofralık üzümü muhafaza etmekte kullanıldığını belirtmeden geçemeyiz. Bu bilgi kırıntısını, pekmez imalatında kullanılması gereken kalitesiz üzümün İstanbul'da muhtemelen siyasal nüfuzlarını standartlara uymayan malları müşterilere kakalamak için kullanan sultanın askerlerince sofralık üzüm diye satıldığına dair şikayetlerden öğreniyoruz. ${ }^{5}$

Bizim araştırmamız, erken modern dönemini ele alacak. Bir diğer deyişle, 1400'lü yılların ikinci yarısıyla başlatacağımız hikâyeyi 1839 yılında ilan edilen Tanzimat fermanıyla noktalayacağız. Bu çalışmanın ilk bölümünde, sofralık zeytin ürünleri ön planda yer alacak. Bu nedenle, dikkatimiz 'zeytinyağı'nın aksine, 'zeytin'den söz eden kaynaklarımıza yönelecek. Gereken işlemden geçirildikten sonra, sofralık ürün olarak satılan zeytin, sadece yemek sofrasında tüketilmiş olmalı. Ama bunun tersine zeytinyağının sabun imalatı, deri bakımı gibi sanayi dallarında kullanılması da söz konusuydu. Ayrıca Osmanlı elitine ait olan, büyük evlerin ve camilerin aydınlatılmasında da kullanılıyordu. Bu konuda az sayııda elimizde bulunan fakat yine çok ilginç belgeler, bu yazının ikinci bölümünde tartışılacaktır. Üçüncü bölümdeyse, Girit ve Suriye vilayetleri için önemli bir faaliyet dalı olan sabun üretimiyle ilgili verilere göz gezdireceğiz. ${ }^{6}$ Dördüncü bölümde, iktisat tarihçilerinin Osmanlı zeytinyağının Fransa'ya yönelik ihracatı konusundaki önemli çalışmalarını kısaca tanıtacağız. Bu literatürün büyük bölümü Fransızca olduğundan, bugün çok sayıda okur bunu görmezden gelme eğiliminde. Biz, en sonunda esas tercihimize, yani XIX. yüzyılın ilk yıllarına tarihlenen belgelerde de kaydedilmiş olan zeytin ve zeytinyağının gıda amaçlı tüketimine geri döneceğiz.

Bazı araştırmacılar, zeytini ticari mal, sanayi hammaddesi ya da üretim bölgesinin toplumsal dinamiğini ele veren bir gösterge olarak ele almışlardır. Bu bildiri boyunca, zeytin,

4 Marianna Yerasimos, Evliya Çelebi Seyahatnâmesi’nde Yemek Kültürü: Yorumlar ve Sistematik Dizin, İstanbul: Kitap Yayınevi, 2011 , s. 68.

5 Fuat Recep et al. ed., İstanbul Kadı Sicilleri İstanbul Mahkemesi, 24 Numarah Sicil [H. 1138-1151/M. 17261738], İstanbul: İSAM, 2010, s. 207.

6 Kolaylık olsun diye, bu terimi Halep’ten kuzeydeki Akabe ve güneydeki Eilat'ı içine alan bölge için kullanıyoruz. Bu durumda bugünkü Suriye, Lübnan, Filistin ve İsrail devletlerini kapsayan topraklar, makalemizde de 'Suriye' olarak anılacaktır. 
zeytinyağı ve bu ürün kaynaklı olan sabunu bir Akdeniz bağlamına oturtmayı deneyeceğiz. 1700'lü yıllarla ilgilenen ve Suriye üzerinde çalışan bir tarihçi için Nablus tartışmasız sabunun başkentiyken, günümüz Marsilya'sına odaklanmış bir başka uzman, kendi araştırma alanı olan bu şehri, sabunun başkenti olarak adlandırmakta tereddüt etmemiştir.

\section{Yüzyılın Sonu, XVI. Yüzyılın Başında Olup Bitenler}

Anladığımız kadarıyla, arşiv belgelerinin yeni çoğaldığı 1500'lü yılların başında zeytin ve zeytinyağı tüketimi bir miktar önem kazanmaktaydı. 1502 tarihli Bursa İhtisab Kanunnamesi'ne göre, bu şehrin sakinleri pazarda Karaburun, Çerkeşde ya da Çerkeşdiye ve 'yalı zeytunu' diye bilinen üç çeşit zeytin bulabilirlerdi. ${ }^{7}$ Karaburun zeytin üretim alanı, İzmir'in batısında, yerel halkın bugün bile çok benimsediği ve kendi kimliğinin inşasında kullandığı özel zeytinlerle tanımlanan bir yarımadadır. ${ }^{8}$ Evliya Çelebi, Karaburun zeytinlerinin ön işlem görmeden, tıpkı meyve gibi yenebildiğini de kaydetmişti. Belki de XVI. yüzyıl Bursa'sında rastladığımız bu yörenin zeytinleri de aynı şekilde tüketilmiş olmalıydı.

Bursa pazarında, Karaburun ve Çerkeşde zeytinin 200 dirhemi bir akçeydi; her zaman küçük farklılıklar olsa da dirhemi 3,1 gramdan hesaplarsak, bu miktar 0,62 kilograma denk düşer. Yalı zeytununun 1 kıyyesi [yaklaşık 1,28 kg] bir akçeye satılırdı: Muhtemelen kalitesi çok daha düşük olduğundan 'yarı fiyata’ satılırdı. Bu farklı fiyatlandırma, Bursa halkının farklı kaliteler arasında ayrım yaptığını gösterdiği gibi, bu olgu bazı tüketicilerin yiyeceklerinde bir ölçüde 'seçici' davranacak kadar alım gücü ve ağız tadına sahip olduklarını da gösterir. Aynı zamanda, Bursa'da şehir pazarlarında satılan çok farklı armut çeşitlerini üç çeşit zeytinle kıyasladığımızda, yerel zeytin tüketiminin sınırları daha net görülebilir.

İlginçtir, her türlü ihtisab düzenlemesinin ana kısmını oluşturan idarece belirlenmiş fiyatlar listesinde [narh], Bursa örneğinde -yanılmıyorsam- zeytinyağından hiç söz edilmediği halde, temelde mumcu ve sabuncuların satın aldıkları farklı tür hayvani yağlarla ilgili en ince ayrıntılara giriliyor. Ancak elimizde bulunan birkaç kaynaktan, XVI. yüzyıl başında Bursa'da zeytinyağı ticareti diye bir şey olmadığını çıkarmak yanıltıcı olur. Aynı zamanda, denize kıyısı olmayan Edirne'de, zeytine hiçbir atıf bulmazken, zeytinyağına sadece tek atıf olduğunu görüyoruz..$^{9}$ İstanbul'a gelince, yiyecekle ilgili bölüm kısa olduğu gibi ne sofralık zeytine, ne de zeytinyağına herhangi bir atıf yapılmıyor.

7 Ömer Lütfi Barkan, "Bazı Büyük Şehirlerde Eşya ve Yiyecek Fiyatlarının Tesbit ve Teftişi Hususlarını Tanzim Eden Kanunlar" Tarih Vesikalar, 1942, I, 5, 326-340; II, 7, 15-40; II, 9, 168-177, bkz. II, s. 21.

8 http://www.karaburunzeytinyagi.com/ [Erişim, 13 Ekim 2015].

9 Barkan, "Bazı Büyük Şehirlerde", III. Bölüm, s. 171. 
En azından, Osmanlı sarayında, Fatih Sultan Mehmet'in mutfağında tereyağı ve kuyrukyağına ek olarak zeytinyağı da kullanılmıştır. ${ }^{10}$ Gelgelelim, 1473 yılında imparatorluk mutfağına ait bir kayıtta zeytinyağının yenilebilir yağlar arasında değil, ayrı bir kategoride listelendiğine, böylece yemeklik yağ olarak değil, başka amaçlarla kullanıldığına işaret eden Faruk Doğan, Fatih'in mutfağında, zeytinyağının yiyecek olarak kullanılmasına şüpheyle yaklaşmıştır. ${ }^{11}$ Ayrıca, 1594-1595 yıllarında çok geçmeden III. Mehmed unvanıyla tahta çıkacak olan Şehzade Mehmed'in mutfağında da tereyağından az rağbet gören, ama içyağı ve kuyrukyağından daha çok tercih edilen zeytinyağı kullanımı önemli oranlara ulaşmıştı. ${ }^{12}$ Ne var ki, muazzam bir miktar farkı vardı: 1527 kıyye zeytinyağına karşılık, 7753 kıyye sadeyağ. Kâtipler, üretim yerini belirtmemiş olduklarından, bu muhtemelen yerel çeşitlere atıf yaptıkları anlamına geliyordu. Arif Bilgin'in toplayıp analiz ettiği atıflara bakarsak, sarayın belli yörelerin zeytinyağına yönelik tercihlere sahip olduğu görülmüyor. ${ }^{13}$

XVI. yüzyıl vergi kayıtlarına yansıyan Ege kıyısı topraklarındaki zeytin üreticiliği, Mübahat Kütükoğlu tarafından analiz edilmiştir. Karaburun'un ünlü zeytin üreticilerinin de bağlı olduğu Çeşme Kazası'nda, zeytinyağı üretimi 1529 ve 1575 yılları arasında önemli artış göstermişti [\% 24]. Bu iki yer, çok düşük üretim düzeyleriyle yola çıkmış olsa da, Çeşme ve Bozyaka yerleşimlerindeki artış $\% 500$ ve daha fazla olmuştu. Öte yandan, ürünün azaldığı bazı köyler de vardı. Bu değişikliklerin nedenlerini belirlemek, imkânsız gibidir: Birincisi, zeytin ağaçları bir yıl bol ürün verirken, ertesi yıl ürün çok az olur ve -genelde mevzuata uymayan gerçek hayatta- kayıtların tutulmasından sorumlu kişilerin bu değişiklikleri ne ölçüde kaydettiklerini söyleyecek durumda değiliz. İkincisi, ender belgelemelerde fazla rastlanmayan, ama bir şekilde yine de ürünü etkilemiş olması gereken hırsızlarla ilgili yerel sorunlar da olmalıydı.

\section{$1600^{\prime}$ lerin Narh Defterleri}

1600'e geldiğimizde, zeytinyağı İstanbul pazarında geçerli olan bir Narh listesinde görülür; bu liste daha önce geçerli olan piyasa fiyatlarını indirmek amacıyla meydana getirilmiştir. ${ }^{14}$ Zeytinyağı sadece tek maddede geçtiğinden, menşei ve kalitesine göre yağ

10 Necdet Sakaoğlu. "Sources for our ancient culinary culture," The Illuminated Table, the Prosperous House, Food and Shelter in Ottoman Material Culture, yay. haz. Suraiya Faroqhi ve Christoph Neumann, İstanbul: Orient-Institut, 2003, s. 35-49, bkz. s. 40.

11 Doğan, "Osmanl Devletinde Zeytinyağ Üretimi", s. 240.

12 Feridun Emecen, "The şehzade's kitchen and its expenditures: An account book from Şehzade Mehmed's Palace in Manisa, 1594-1595”, age., s. 89-126, bkz. s. 96.

13 Bilgin, Saray Mutfă̆g, passim [bkz. defter].

14 Mübahat Kütükoğlu, “1009 [1600] tarihli Narh Defteri’ne göre İstanbul’da çeşitli eşya ve hizmet 
sınıflandırması olmadığı anlaşılır. Tersine, zeytinin kendisi daha çok dikkat toplamış^tır: Metin, Aydıncık/Edincik ve Midilli adası isimleriyle tanımlanmış sofralık zeytinden söz eder. Bunun yanı sıra coğrafi menşei belirtilmeyen, diğer ikisinden pahalı olan ve sırf hasır zeytunu diye geçen üçüncü bir çeşit mevcuttur. Defterde, hasır zeytininin diğer çeşitlerden daha iyi olduğu yazılmıştır; fiyatıysa yeni fiyatlandırmadan önce 5-6 akçeyken sonra 3-4 akçe olmuştur. Dolayısıyla, hasat sırasında halkın zeytini ağaçların altına serdiği hasıra düşürdüğünü varsaymak mantıklı olacaktır. 1700'lü yıllarda, Fransız tüccarlar, üreticilerin prese her tür saf olmayan ürünü soktukları için genelde Girit zeytinyağının kalitesizliğinden şikayet ediyorlardı. Bu nedenle, hasır zeytununun daha özenli işlemden geçtiğini varsayabiliriz. ${ }^{15}$ Manisa sarayı, 1594-1595 yıllarında muhtemelen indirimli olarak aldığı zeytine 4 akçe ödediği için, şehzadenin dairesinde tüketilen zeytinin kalite yönünden hasır zeytununa benzediği söylenebilir.

Ünlü 1640 Narh defterinde, kâtipler zeytin konusunda çok az şey yazmadıkları halde en azından zeytinyağının, susamyağına [şir-i revgan] eşit değer taşıdığı netleşmektedir; ikisinin de kıyyesi 20 akçe etmiştir. ${ }^{16}$ Zeytin çeşitlerine gelince, 'Karaburun'u görürüz; 1502'den de tanıdığımız bu çeşit, 1640 yılında Edincik/Aydıncık çeşitlerinden iki kat pahalı olmaktadır. Böylesine büyük fiyat farkı konusunda, kâtiplerin bir açıklaması olmadığı gibi bu defterde Midilli zeytininden hiç söz edilmemiştir.

Biraz harcayacak parası olan İstanbullu tüketicilerin, dört çeşit zeytin satın aldığını böylece bilmekle birlikte, zeytinyağı standart bir kaliteyi yakalamış olmalı; sarayda bile değişik ve daha nadide bir ürün tercih edilmiyordu. Bu durumda, İstanbul'da kullanılan zeytinyağının ne kadarının yemeklik olarak, ne kadarının sultanın sarayında çok sayıda bulunması gereken lambalarda yakıt olarak kullanıldığını merak etmekten kendimizi alamiyoruz.

\section{Edremit'e Odaklanmak:}

Evliya Çelebi, Kazanın Ölmüşleri ve Müridoğlu

Kalburüstü bir seyyah olarak Evliya Çelebi, imparatorluğun zeytin ağaçlarının yetiştiği birçok vilayetini gezdiği için olsa gerek, çok sayıda zeytin çeşidini bilir. ${ }^{17}$ Aydıncık/ Edincik ya da Midilli’den söz etmeyişi ilginçtir; seyyahın veri topladığı yüzyllın ortasında,

fiyatları," Tarih Enstitiusü Dergisi, IX [1978], 1-86, bkz. s. 26-27.

15 Patrick Boulanger, Marseille marché international de l'huile d'olive: Un produit et des hommes 1725-1825 [Marseilles: Institut Historique de Provence, Économies modernes et contemporaines, 1997], s. 45.

16 Mübahat Kütükoğlu, Osmanlllarda Narh Müessesesi ve 1640 Tarihli Narh Defteri, İstanbul: Enderun Kitabevi, 1983, s. 91 ve 94 .

17 Yerasimos, Evliya Çelebi Seyahatnâmesinnde Yemek Kültürü, s. 538. 
bu zeytinlerin İstanbul'a ulaşıp ulaşmadığını bilmek zor. Narh Defterleri'nden ve Evliya Çelebi'nin yazdıklarından tek bildiğimiz çeşit Karaburun'dur; ayrıca Urla yakınlarındaki zeytinlerden de söz eder. Dahası, seyyah Anadolu'nun batı kıyısındaki Mekri [günümüzün Fethiye'si] ve Edremit dışında, bugünkü Güney Yunanistan [Aydonat, Gaçiça, Koron, Modon] gibi tanınmış zeytin üretim alanlarındaki zeytinlerden de söz eder.

Evliya Çelebi'nin, Edremit'le ilgili notu ilginçtir; çünkü bu kısa metin, sonradan zeytinyağı pek ünlü olan kasabanın bu konuda yapılmış olan ilk atıflarından biridir. Edremit zeytinciliği gerçi daha eskidir. Zira Fikret Yllmaz, bölgedeki büyük zeytinliklerin, XVI. yüzyılın sonlarına doğru ölen kişilerin tereke defterlerinde, ilk kez ortaya çıktığına işaret etmiştir. Ne var ki, 1500'lerin başında bile, Edremit'in köyleri saraydaki tüketim için mütevazi bir ölçüde olsa bile bir miktar zeytinyağı üretmiştir. ${ }^{18}$ Üretim daha sonra -çalkantılı bir biçimde olsa bile- devam edebilmiştir. Zira kötü bir hasadın yerel tüccarları izin verilenden daha yüksek fiyatlar talep etmeye zorladığı 1144/[1731-1732] yılında, Edremit zeytinyağları, İstanbul kayıtlarında yeniden boy göstermiştir. ${ }^{19}$

Edremit zeytinleri, burada incelenen dönemin sonundan kısa süre önce, 1822-1823 yılları arasında bir kez daha dikkatimizi çekti. Çünkü bu sırada Müridoğlu diye bilindiğinden derviş çevrelerinden geldiği sanılan Hacı Mehmed Ağa adlı yerel bir mültezim, en az 19.209 zeytin ağacı sahibi olarak ortaya çıkmıştı. Kendi zeytinyağı preslerini ve sabun atölyelerini işlettiği; zeytinyağını ve sabununu en azından kısmen krediyle sattığı anlaşılmıştı. Müridoğlu'nun, yörenin köylülerine borç verip ödeme zorluğu çekenlerin ağaçlarına el koymuş olması, kanıtlanmasa da mümkündü. ${ }^{20}$ Zeytinyağının bir kısmı İstanbul'da Askeri Tersane'ye gidiyor; burada işçilerin beslenmesinde kullanıldığı gibi karanlıkta iş yerlerini aydınlatmakta da kullanılıyordu. Bütün bu süre boyunca, İstanbul'a oldukça yakın olan Edremitli üreticilerin, Osmanlı başkentine mal göndermekte yoğunlaştıkları anlaşılıyor.

\section{Eski Zeytin Ağaçlarının Toprağı: Suriye Vilayetleri}

Evliya Çelebi, Osmanlı anakara toprakları dışında, Gazze, Şam, Trablusşam ve Kudüs'te de zeytin üretildiğini biliyordu. Arşiv belgelerinden anladığımız kadarıyla, XVI. yüzyıl

18 Fikret Yılmaz, "XVI. yüzyılda tarımsal yapılarda değişim ve yağ kullanımı", Tarih ve Toplum, 10 [ilkbahar 2010], s. 23-42.

19 Recep et al. ed., 24 Numaral Sicil, s. 398: Verilen dilekçeden.

20 Suraiya Faroqhi, "Wealth and Power in the Land of Olives: the Economic and Political Activities of Müridoğlu Hacı Mehmed Ağa, Notable of Edremit [died in or before 1823]", Landholding and Commercial Agriculture in the Middle East içinde; yayına hazırlayanlar: Çağlar Keyder ve Faruk Tabak, Albany: SUNY Press, 1991, s. 77-96, Making a Living in the Ottoman Lands, 1480-1820'de yeniden basılmıştır, İstanbul: The Isis Press, 1995, s. 297-317. 
Osmanlı kâtipleri, Kudüs vilayetinde İslamiyet öncesi zamanlardan kaldığı düşünülen [zeytun-ı rumani] zeytinlerle, İslam fethinden sonra ekilen zeytinler [zeytun-ı islami] arasında ayrım yapmışlardı. Halep bölgesinde de aynı ayrım geçerliydi. ${ }^{21}$ Bu iki kategori arasındaki fark, vergi biçiminde görülüyordu: Bazen kâfiri de denilen zeytun-ı rumani örneğinde, köylü ürünün yarısını alırken, diğer yarısı vergi toplayana verilirdi. Oysa Kudüs vergi defterlerinde, 'zeytun-ı islami' diye tanımlanan her iki ağaçtan bir akçe olmak üzere standart bir miktar alındığı yazılıdır. Ne var ki, istisnalar da az olmadığından, iki kategori arasındaki fark çok bulanıklaşmıştı. Söz konusu ağaçların yaşlarını bilmediğimiz halde, bazılarının Osmanlı fethinde bin yıllık olması imkânsız değildi. Ne olursa olsun, sultan ve vezirleri Kudüs ve Halep'in, Osmanlıların bölgeye gelişinden asırlar önce zeytin ürettiğinin farkındaydılar.

Filistin'in Nablus kazası örneğinde, zeytinciliğe Memluk dönemi kayıtlarında rastladığımız halde, zeytinciliğin çok daha eski tarihlerde başlamış olması pekâlâ mümkün. 1700'ler ve 1800'lerde ağaçlar, zeytinyağını sabun tacirlerine satan köylülerin elindeydi; yerel güç sahibi olan bu sabun tacirleri, sıklıkla Osmanlı vilayet yöneticileriyle iş ya da akrabalık ilişkisi içindeydiler. Köylüler vergi ödemek, kötü hasat dönemlerini atlatmak ya da ailevi yükümlüklerini yerine getirmek için çok slk paraya ihtiyaç duyduklarından, genelde selem diye bilinen sözleşmeler yaparlardı. Bu yolla para alıp, karşılığında borcunu kredi veren tüccarla önceden kararlaştırılan bir miktarda zeytinyağıyla ödemeyi taahhüt ederlerdi; bu yolla köylülere verilen fiyat mallarının piyasa değerinin altında olurdu ve genelde bu fark oldukça büyüktü. ${ }^{22}$

\section{Aydınlatmada Kullanılan Zeytinyağı}

Erken modern dönemde, İstanbulluların evlerini nasıl aydınlattığı konusunda neredeyse hiçbir bilgiye sahip değiliz. Genelde, sıradan şehir halkının güneş batınca yattığı, güneş doğduğunda kalktığı iddia edilmiştir; ama böyle bile olsa aydınlatmaya ihtiyaçları vardı. Sözgelimi, İstanbul'da yılın en kısa gününde alınan gün ışığı, sadece dokuz saatti. Ne var ki, özel evlerde, en azından sıradan günlerde ve geceleri çoğunlukla hayvani yağ yakılan lambaların kullanıldığı anlaşılıyor.

Öte yandan, sultanın birkaç gece donanma, başka bir deyişle kentteki tüm evlerin dıştan aydınlatılması emri vermesi de yeterince bilgilendiricidir. Çatılara ve pencerelere mum koymak çok riskli olduğundan, muhtemelen bu tür şenliklerde zeytinyağı kandillerinin

21 Amy Singer, Palestinian Peasants and Ottoman Officials: Rural Administration Around Sixteenth-Century Ferusalem, Cambridge: Cambridge University Press, 1994, s. 48-50.

22 Beshara Doumani, Rediscovering Palestine: Merchants and Peasants in Fabal Nablus, 1700-1900, Berkeley: University of California Press, 1995, s. 134-139. 
yakılması tercih edilirdi. Ne var ki, bu amaçla zeytinyağının mı, yoksa daha ucuz olan sıvıyağların mı kullanıldığını bilme şansımız yok. Donanma, bir sultan ya da şehzadenin doğumunu ya da savaşta kazanılan bir zaferi kutlamak için emredilebilirdi. Bu uygulama İstanbul'la sınırlı değildi; diğer büyük şehirlerde de görülüyordu. 1671 yılında, bu tür bir olaya Halep'te tanık olan Venedikli seyyah Ambrosio Bembo, aydınlatmanın gece gezintisi için yeterli olduğunu söylemişti. ${ }^{23}$ İçinde zeytinyağı yakılan fitilli cam kandiller, bayram münasebetiyle minareler arasına asılırdı. Bugün de süren bu uygulamada, kandiller ışıklı yazılar oluşturacak şekilde dizilirdi. Bu süsleme, mahya diye bilinirdi. Erken modern şehirlerde, sıradan gecelerin zifiri karanlık olduğu düşünülürse, bu şekilde ışıklı dini yazılar özellikle etkileyici olmalıydı.

24 Ramazan 1128/[11 Eylül 1716] tarihinde, bu uygulamanın yeni bir versiyonu ortaya çıktı. İstanbul, Galata, Eyüp ve Üsküdar'da sultan ve vezirlerin yaptırdıkları camilerin idarelerine, Mekke, Medine, Kudüs, Şam ve Halep'te uzun süredir var olan bir adeti taklit etmeleri emredildi. Bu yeni uygulama, Müslümanların iki büyük bayramını kutlamak için, akşam ezanının tamamlanmasından sonra, şerefelere yanan kandiller yerleştirmekten ibaretti. ${ }^{24}$ Yorumumuz doğruysa zamanın sultan ve ileri gelenleri için -günümüzde halen devam eden- bu geleneğin Arap eyaletlerinde ve özellikle Hicaz'daki bir uygulamadan kaynaklanması özellikle önemliydi. Yine de idareciler, İstanbul'da çok miktarda zeytinyağı yakmaktan açıkça çekiniyorlardı. Bu yüzden de cami idarelerine, ısrarla bayramın sadece ilk günleri kandilleri yakmaları emredilmişti. Belki de Sultan III. Ahmed'in para tasarrufuyla ilgili endişeleri, bu özel uyarının yapılmasına neden olmuştu.

Anlaşılan o ki Ramazan gecelerinde minarelerin aydınlatılması, İstanbul'da bu fermanın verilmesinden çok önceleri adet olmuştu. Çünkü ferman, kandillerin iki bayram gecelerinde ramazandakinden farklı düzenlenmesini vurgularken, mahyalar açıkça 'id-i şerif, id-i mübarek'e atıf yapacaktı. Tekrarlarsak, fermanda hangi tür yağın kullanılacağı hakkında hiçbir şey söylenmiyordu; fakat en azından kısmen zeytinyağının kullanıldığını varsayabiliriz.

Tüm para tasarruf etme çabalarına karşın, hatırı sayılır miktarlarda zeytinyağı tüketmiş olmaları gereken mahyalarla ilgili biraz daha fazla bilgimiz var. Müzelerde ilk önceleri Orta Çağ Suriye'sinde imal edilen, ama çok geçmeden Venedik'in Murano Adası'ndaki atölyelerde başarılı taklitleri üretilen çok sayıda zarif işlemeli cam kandiller bulunur. Muhtemelen çok az süslemeli ya da hatta sadece kandiller, İstanbul'a büyük miktarlarda

23 Ambrosio Bembo, The Travels and Fournal of Ambrosio Bembo, tr. by Clara Bargellini, baskiya hazırlayan ve notları düzenleyen: Anthony Welch, Berkeley, Los Angeles, London: University of California Press, s. 78.

24 Recep et al, ed., 24 Numarah Sicil, s. 38-39. 
ihraç edilmişti. 1579 yılında öldürülen Sadrazam Sokollu Mehmed Paşa'nın, bir keresinde Venedik’e camiler için dokuz yüz kandil sipariş ettiğini biliyoruz. İmalatçıların onun tasarladığı şeyi iyi öğrenmeleri için, model çizimler bile göndermişti. ${ }^{25}$

Zeytinyağı, ayrıca Mekke'deki Mescid-i Haram'ın aydınlatılmasında da kullanılmıştı. Bu örnekte, gerçekten de zeytinyağı kullanıldığını bilmekten hoşnutuz. 1565-1566 tarihli, başka bir deyişle, Kanuni Sultan Süleyman'ın hükümdarlığının [r. 1520-66] son yılında hazırlanmış bir belge, Mescid-i Haram'ın idarecilerinden İbrahim'in camii ambarlarında zeytinyağının kalmadığından şikâyet ettiğini okuruz. ${ }^{26}$ İbrahim, bu ürünün bulunmamasına işaretle, Mescid-i Haram'ın kötü aydınlatıldığını, dolayısıyla da akşam ve yatsı namazlarında camiye gelenlerin çoğunun yaşlı olduğunu, müminlerin namazı kıldıran imamı bile göremediklerini söylemişti. İbrahim'in şikâyetine bakılırsa, avluyu aydınlatması gereken üç yüz seksen yedi kandil olmalıydı; ama zeytinyağı kalmadığı için bunlardan, iki yüz seksen beşi yakılmıyordu. Kalan küçük kandillerin de aydınlatması yetersiz olduğundan, avlunun büyük bölümü karanlıkta kalmış olmalıydı. Ayrıca, idareciler tasarruf etmek amacıyla kandilleri yatsı namazından sonra söndürtüyorlardı. Ama bu çözüm de soruna çare bulmamıştı, çünkü birçok kişi gece yarısı bile camiyi ziyaret ediyordu. İbrahim, bu nedenle padişahın bağışı olarak, yüz elli kantar zeytinyağını talep ediyordu. Ancak hükümdar muhtemelen yolsuzluğun önüne geçmek için, bu bağışın kadı defterlerine yazılmasını emretmişti. Bu emirlerin yerine getirilmediğini belirtelim. 1568 tarihli bir belgede, Mekke'ye gönderilen balmumu ve zeytinyağının istenen amaçlarla kullanılmadığı belirtilmişti. İstanbul ve Anadolu'daki vakıfların belgelerinde de çoğu örnekte muhtemelen aydınlatma amacıyla kullanılan zeytinyağına atıflar vardı.

\section{Zeytinyağının Sabun Yapımında Kullanılması}

Sabun, günümüzde palmiye ağaçlarından elde edilen nispeten ucuz yağlar dâhil çok çeşitli yağlı malzemelerden imal edilebilir. Ayrıca, defne yağı Suriye ve Lübnan'da hâlâ revaçtadır. Ne var ki, bugün bile en çok rağbet gören zeytinyağından yapılan sabunlardır; bu Tanzimat öncesi dönem için de kesinlikle doğruydu. ${ }^{27}$ Osmanlı döneminin Suriye'sini

25 Rosa Barovier Mentasti and Stefano Carboni, "Enameled Glass between the Eastern Mediterranean and Venice," Venice and the Islamic World 828-1797 içinde, yay. haz. Stefano Carboni, New York, New Haven, London: The Metropolitan Museum of Art, Yale University Press, 2007, s. 252-275, bkz. s. 268-271.

26 Suraiya Faroqhi, Pilgrims and Sultans, Londra: I. B. Tauris Press, 1994, s. 103-104.

27 https://www.saudiaramcoworld.com/issue/201004/soaping.up.htm [Erişim: 16 Ekim 2015].

Eric Calderwood and Alexandra Avakian, "Sabunlamak,” XXI. yüzyıl Halep, Trablus ve Sayda'daki zeytinyağı ve defne sabunu üreticilerinin piyasanın kaprislerine nasıl uyum gösterdiklerine dair iyi belgelenmiş bir makaledir. Calderwood ve Avakian’ın röportaj yaptıkları sabuncu ailelerden biri olan Şarkass'ta 
oluşturan eyaletlerde sadece zeytinyağı değil, hem cam, hem de sabun imalatında kullanılan yosun sodası [barilla] gibi bazı bitkilerin külleri de kolayca bulunabiliyordu ve 1700'lü yılların başında, İngiliz tüccarlar bazen bunları ihraç ediyorlardı. ${ }^{28}$

XVIII. yüzyılda, sabun imalatı Kudüs ve Nablus bölgesi gibi, özellikle Halep hinterlandındaki şehirlerde olmak üzere bugünkü Suriye'de önemli bir sanayiydi. Daha 1500'lü yılların ortasında, Kudüs bölgesinde üretilen sabunlar Mısır'da ve hatta İstanbul'da satılıyordu. ${ }^{29}$ Ayrıca, bugünkü Lübnan'da bulunan Trablus ve Sayda sabun imalathaneleriyle de meşhurdu. Trablus'ta, Sabun Hanı XVI. yüzyılda inşa edilmişken yerel sanayi daha çok 1600'ler ve 1700'lerde gelişmişti. Girit Adası'nda, sabun imalatı Osmanlı egemenliğinin artık yerleştiği XVIII. yüzyıl boyunca önemli ölçüde artmıştı. 1723 yılında, altı olan sabun imalathanelerinin sayısı, 1700'lerin ortasında on ikiyi bulmuş ve 1783 yılında on sekize Çıkmıştı. ${ }^{30}$

XVII. yüzyılda, Tunus'ta sabun imalatı belli bir öneme sahip bir sanayiydi; pek çok mahallinde tüketildiği halde, Tunuslu tüccarlarca en güvenilir pazarlar sayılan Mısır'a ve Osmanlı merkezi vilayetlerine de sevk ediliyordu. ${ }^{31}$ Ayrıca, yaklaşık 1660 yılına kadar, 'Tunus Malı sabun' Marsilya ve Livorno'ya da ihraç edilirdi. Ama 1660 yılından sonra, muhtemelen 166l'de kişisel yönetimi başlayan XIV Louis [1638-1715] hükümetinin korumacı politikalarına bağlı olarak, Güney Fransa'ya sabun ihracatı aniden kesildi.

Ama XVIII. ve erken XIX. yüzyıl Nablus'unun, sabun sanayiyle ilgili oldukça çok bilgiye sahibiz. 1820'lerde, sabun imalatı fabrika ayarında büyük atölyelerle birlikte ciddi ölçülerde büyüme gösterdi. Bu imalathanelerin tümü, bunları çalıştıran kişilerin ailelerinin faydalandığı vakıflara dönüştüklerinden, çok sayıda mirasçı arasında bölünmekten ve dolayısıyla ortadan kaybolmaktan korundular. ${ }^{32}$ Üretim, kısmen selem ile köylülerden zeytinyağı satın alan ve yerel Bedevilerden yosun sodası [barilla] temin eden sabun tacir-

1803’ten beri Lübnan’ın Trablus şehrindeki tarihi Sabun Hanı'nda sabun imal ediyordu. Bu nedenle, Calderwood ve Avakian yazılarında yakın gecmişsle yetinmeyip XIX. yüzyılı da araştırmalarının kapsamina aldılar.

28 Bu bilgiyi, M. Sait Türkhan’ın şifahen ilettiği bir tebliğe borçluyum: "1704-1706 Yılları Arasında İskenderun Limanı'ndan Yapılan İngiliz İhracatı Hakkında Bazı Gözlemler”, Uluslararası Osmanlı Araştırmalar Kongresi, Sakarya Üniversitesi [14-17 Ekim 2015].

29 Singer, Palestinian Peasants, s. 78.

30 Molly Greene, A Shared World: Christians and Muslims in the early modern Mediterranean, Princeton, N. J.: Princeton University Press, 2000, s. 137, not: 132.

31 Boubaker Sadok, La Régence de Tunis au XVIIe siècle: ses relations commerciales avec les ports de l'Europe méditerranéenne, Marseille et Livourne, Zaghuan: Centre d'Études et de Recherches Ottomanes et Morisco-andalouses, 1987, s. 130.

32 Doumani, Rediscovering Palestine, s. 182-217. 
lerince kontrol ediliyordu. Sonra bu hammaddeleri fabrikalara veriyor; fabrikalar da tacirlerin yerel olarak pazarladıkları ve/ya da diğer Osmanlı vilayetlerinde oturan ve yüksek kaliteye değer veren müşterilere gönderdikleri kalıp sabunlar üretiyorlardı. Ayrıca fabrika sahipleri da hammadde satın alıp ürettikleri sabunu kendi nam ve hesaplarına satıyorlardı. Özellikle Tanzimat yasaları işadamlarına yerel güç verdikten sonra, bu adamlar şehir hayatına egemen olmuşlardı.

\section{İhracata Dönük Zeytincilik}

Osmanlı zeytinleri ve zeytinyağıyla ilgili bilgilerin bir kısmını, Fransız kaynaklarında buluyoruz. Çünkü 1700'lü yıllara geldiğimizde, Marsilya şehri hem Fransa'nın içindeki, hem de dışındaki üretim merkezlerinden gelen zeytinyağı için, büyük bir uluslararası piyasaya dönüşmüştü. Ne var ki, 1709 yılındaki dondurucu soğuklar ve şiddetli yağmurlar yüzünden, ağaçların büyük bir bölümü öldüğünden zeytinyağı piyasası büyük bir krize girmişti. ${ }^{33} 1709$ yılındaki iklim felaketi, bütün Akdeniz havzasında kendini hissettirdiğine göre Midilli, Edremit ya da Karaburun gibi, Osmanlı dünyasının kuzey alanlarındaki ağaçlarını da etkilenmiş olması mümkün. Ancak bu konuda, herhangi bir kanıt elde etmiş değiliz. Ancak komşu Aix-en-Provence'da üretilen zeytinyağını yemek pişirmekte kullanmaya alışık olan Marsilyalı tüketiciler, daha güneydeki kaynaklara yönelmiş olmalı. Bir zeytinliğin yeniden yetişmesi uzun yıllar aldığından, bu ithalat uzun bir zaman dilimine yayılmış olmalı.

Oysa daha iyi zamanlarda Aix-en-Provence zeytinyağı, üreticilerin hasattaki özeni nedeniyle meşhur olmuştu. Öte yandan, önceden not ettiğimiz gibi Fransız tüccarları genelde bu konularda Girit ya da anakara Yunanistan köylüsünden özensiz davranışları nedeniyle şikayetçiydiler. Faruk Doğan, Anadolu örneğinde bu durumu detaylı anlatmıştır. En başta, birçok üretici ağaçlarını budamıyordu. Ayrıca zeytinlik sahipleri, olgun zeytinlerin çalınacağı korkusuyla, beklemeden hasat yapmak istiyorlardı; ama genelde alelacele çalışmalar ağaçlara zarar veriyordu. Ayrıca, uygun depolama tesisleri olmadığından, zeytinler preslenmeden önce bozuluyordu. Daha kötüsü, bazı üreticiler zeytinin çürümesine izin verildiği takdirde, zeytinyağının daha kolay elde edileceğine inanıyorlardı. Sonuçta, zeytinyağının insanların tüketmesi için uygun olmayan kötü bir kokusu oluyordu. ${ }^{34}$ Muhtemelen, 1923 Mübadelesi'nin de Anadolu'daki zeytinlikler üzerinde olumsuz etkisi olmuştu: Ege sahil şeridinde zeytin yetiştiren pek çok üretici, XX. yüzyıl ortasında bile toprağa henüz yeni yerleşmiş ve muhtemelen gerek ağaçlarının bakımı, gerekse İstanbul ve dış

33 Emmanuel Le Roy Ladurie, The Peasants of Languedoc, çev.: John Day, Urbana, Chicago, London: University of Illinois Press, 1974, s. 230. Ayrica bkz ; Boulanger, Marseille, s. 32.

34 Faruk Doğan, Osmanh Devletinde Zeytinyağı Üretimi, s. 236. 
piyasaların talepleri konusunda fazla tecrübe sahibi olmayan eski göçebelerdi. ${ }^{35}$ Faruk Doğan'ın yararlandığı kaynaklar, 1800'ler ve 1900'lere ait olmakla birlikte, Fransız kaynaklarının şikâyetlerini defalarca tekrarladığına göre, aynı problemler geniş bir zaman dilimine yayılmıştı. ${ }^{36}$

Bununla birlikte, 1700’lerde ‘sabunun başkenti’ne dönüşmüş bir kent olan Marsilya'nın tüccarları için, kalite sorunları o kadar önemli değildi. Çünkü sabun imalatında kullanılan ithal zeytinyağında yüksek kaliteli üretim gerekli değildi. 1688 tarihli bir kraliyet fermanı, Marsilya şehrinde sabun imalatında zeytinyağı dışında herhangi bir yağın kullanılmasını yasakladığı halde, başka yerlerde kolza, fındık ve tohum yağları da kullanılıyordu. Oysa Suriye'deki gibi, zeytinyağından üretilen sabunların daha kaliteli olduğuna inanılıyordu. XVIII. yüzyılda Avrupalılar çok sık yıkanmadıkları halde, düzenli giysilerini değiştirdiklerinden, sıradan el sabunları çok talep görürdü. Bunun dışında, renkli ve parfümlü lüks sabunlar da Provence sanayince üretiliyordu; bu tip üretim, bugün de sürmektedir. ${ }^{37}$ Ayrıca, sıcağa ve ışığa bilerek maruz bırakılarak ‘bozulan' zeytinyağı, boya sanayinde kullanılıyordu. 1700'lerin ikinci yarısından başlayarak, imalatçılar zeytinyağını Osmanlı dünyasından ithal edildiği açık olan bir teknolojiyle, Türk Kırmızısı ya da Edirne Kırmızısı [kök boya] denilen boyanın üretiminde kullanmışlardı. 1700'lerde, zeytinyağı çeşitli Avrupa ülkesinde üretilen ve Osmanlı topraklarına ihraç edilen imitasyon 'Tunus bonesi' ya da feste kullanılan yünün işlenmesinde de kullanılmıştı. Yüzyılın sonunda, bu pazarın giderek küçülmesinden sonra, feslere benzer boneler güney Fransa'da işçiler arasinda popüler olmuştu. ${ }^{38}$

Erken modern dönemde, ancak gerektiğinde yapılan ithalatın çoğunlukla hammaddelerden, ihracatınsa mamul mallardan oluşması ilkesine dayanan yaygınlaşmış Avrupa siyasetine uygun olarak, Marsilya sabununun en büyük kısmı sonuçta yurtdışına giderdi. Ürün Hollanda'da, bir Kuzey Denizi limanı olan Hamburg'ta ve hatta İsveç'te müşteri bulurdu. Marsilyalı sanayi malları üreticileri, kesinlikle yabancı pazarlarını kaybetmek istemediklerinden, 1709'da çok sayıda zeytin ağacını don vurması yüzünden, başka yabancı zeytinyağı tedarikçilerine ihtiyaç duydular ve yeni kaynaklar elde ettiler. Bu yeni tedarikçilerin tümü değilse bile birçoğu Osmanlı tebaasıydı.

İspanya ve özellikle İtalya, Marsilya sanayinin ana kaynakları oldukları halde, biz

35 Altan Gökalp, Têtes rouges et bouches noires: une confrérie tribale de l'ouest anatolien, Paris: Société d'Ethnographie, 1980, s.157-168. Yazar, saha çalışması sırasında gözlemlediği teknolojilerin çok eski olduğuna işaret etmiştir.

36 Boulanger, Marseille, s. 48.

37 Boulanger, Marseille, s. 36.

38 Boulanger, Marseille, s. 66, 142, 143. 
sadece Fransa'ya Osmanlı topraklarından ithal edilen zeytinyağına göz gezdireceğiz. Bugünkü Güney Yunanistan, Ege Adaları ve Anadolu'nun batı kıyısı dışında, başlıca üç zeytin üreticisi doğu Akdeniz kıyı şeridi, Girit ve Tunus'tu. 1770 yılında, Peloponnes'te Prens Orlov komutasındaki bir Rus donanma filosunun çıkarma yapmasından kaynaklanan bir ayaklanma oldu. Orada bulunan Fransızların güvenliğini sağlamaya çalışan, Fransız konsolosunun bir raporu elimizde. Fransızların orada bulunma nedeni, muhtemelen zeytinyağı ticaretiydi. ${ }^{39}$ Ama miktar yönünden Girit, özellikle bir dizi yıpratıcı savaşın arkasından, padişahın oldukça yüksek özel bir vergi [bid'at] ödenmesi karşılığında, zeytinyağı ihracatına eskiden konan yasağı kaldırdığı 1718 yılından sonra, Girit’in önemi iyice artmıştı. Mali nedenler dışında, çoğunlukla Fransız tüccarları için yararlı olan bu izin, kesinlikle savaş sonrasının ekonomik canlanmasının yaygınlaştığı bir dönemde, Fransa'yla ilişkilere istikrar kazandırma ihtiyacıyla ilgiliydi. Ayrıca, Osmanlı merkezinin vilayetler üzerindeki kontrolü şimdi bir ya da iki yüzyıl öncesine göre azalmış durumdaydı. Ancak muhtemelen barışla birlikte Girit Adası'nın Osmanlı toprağı olmasıyla, zeytinyağı üretimindeki artışın da bu tutum değişikliğinde rolü olmuştu. ${ }^{40}$ Girit, gerek meşru ihracat yoluyla, isterse kaçak yollarla, Marsilya sanayii için İtalyan Riviera'sıyla birlikte başlıca tedarik kaynağıydı: 1726 yılında, toplam ithalat 144.021 birim zeytinyağıyken, bunun kabaca 80.189'u [\%55'ten çoğu] Osmanlı topraklarından geliyordu. Ayrıca o zamana kadar 32.800 birimle, Girit'teki Hanya kazası Marsilya'da kullanılan zeytinyağının en önemli tekil kaynağıydı [\%22'den fazla]. ${ }^{41}$

\section{Yerel İhtiyaçlara Dönüş: 1800 ’lerin Başında Beslenme Amaçlı Zeytin ve Zeytinyağı Tưketimi}

XVIII. yüzyılda ve XIX. yüzyılın ilk yıllarında, Rusya'yla savaşlar ve arkasından Güney Yunanistan'daki ayaklanmalar dolayısıyla yapılan deniz seferleri neticesinde, İstanbul'daki gıda stokları tehlikeli bir biçimde azalmıştı. Belki de şimdiki bakış açımız yönünden en önemli olanı, Sultan II. Mahmud'un [saltanatı 1808-1839] Mısır Paşası Mehmed Ali'yle uzun süreli bir çatışmaya girmesiydi; Mehmet Ali'nin oğlu, İbrahim Paşa 1840 yılına kadar Suriye'yi elinde tutmuştu. Sonuçta, uzun yıllar boyunca ne Girit, ne de Suriye, İstanbul'a artık herhangi bir miktarda zeytinyağı sağlayamamıştı ve dahası, devir Sultanlarının İstanbul sakinlerine yiyecek temin etmek için genelde beyhude çabalarla, ferman

39 Suraiya Faroqhi, "Representing France in the Peloponnesus: a Wealthy French Dwelling in 1770", Suraiya Faroqhi and Christoph Neumann içinde, ed., The Illuminated Table, the Prosperous House, Food and Shelter in Ottoman Material Culture, İstanbul: Orient-Institut, 2003, s. 255-273.

40 Greene, A Shared World, s. 132-137. Boulanger, Marseille, s. 46.

41 Boulanger, Marseille, s. 162. 
üstüne ferman çıkardıkları yıllardı. ${ }^{42}$ II. Mahmud'un başkent sakinlerine zeytinyağı tedarikiyle ilgili bir fermanını, işte bu bağlamda yorumluyoruz. 1818 yılında yetkililer, İstanbul'un yılda 5.632 .000 kilogram zeytinyağı ihtiyacı olduğunu ilan etmişlerdi. Ne yazık ki, bu miktarı hesaplarken nasıl bir kıstas kullandıklarını bilmediğimiz gibi, bu yağın ne kadarının aydınlatmada ve beslenme dışında kullanıldığını da söyleyebilecek durumda değiliz. 1830 yılında, İstanbul'a yakın bölgelerin üreticileri, gerekli yağı aylık bölümler halinde gönderme emri alırlarken, zeytinyağı ticaretini organize ederek, yetkililerin vurguncu saydıkları özel tacirleri denetleyecek ya da devreden çıkaracak özel bir daire kuruldu. ${ }^{43}$ Oysa bu düzenlemeler duruma çare olmadığından, Tanzimat’a kadar İstanbul'a zeytinyağı arzında önemli eksiklikler görüldü. Üretimin sekteye uğramasında, belki de Edremitli Müridoğlu gibi büyük üreticilerin tasfiyesinin payı vardı.

XIX. yüzyılın başında, Osmanlı idarenin önceden alışık olmadığımız bir biçimde zeytinyağı ticaretine müdahalesi de dikkat çekicidir. XVI. yüzyılda, tahıl, deri, metaller, silah, pamuk ve üzüm/kuru üzüm, hükümetin dikkat alanındaki başlıca kaynaklarken, XVIII. yüzyılın çoğu bölümünde ihracata dönük zeytinyağı ticareti, en azından Peloponnes ve Girit örneğinde badirelerden kurtularak sürdürülmüştü. ${ }^{44}$ Osmanlı merkezi yönetiminin zeytinyağı arzını düzenlemeye duyduğu ilginin, artan tüketimin göstergesi mi olduğunu, yoksa sadece 1800'lerin başında yaşanan kriz durumundan mı kaynaklandığını merak edebiliriz.

\section{Sonuç}

Birincil ve ikincil kaynakların bu kısa incelemesi, Faruk Doğan, Marianna Yerasimos, Fikret Yllmaz ve diğer akademisyenlerin bulgularını, yani zeytinyağının Tanzimat öncesi İstanbul mutfağında gıda olarak sınırlı role sahip olduğunu doğruluyor. Anlaşılan, en azından 1500'lü yıllardan başlayarak, gurmeler 'olduğu gibi' yenen bazı zeytin çeşitlerini, özellikle Karaburun zeytinini beğenmişlerdi. Ne yazık ki, kahvaltıda peynir ekmekle birlikte zeytin yeme adetinin ne zaman başladığını söyleyebilecek durumda değiliz. Sözgelimi, armut ya da üzümle karşılaştırılırsa, idarenin belirlediği fiyat listelerinde zeytine ender atıf yapılmış olması da tüketicilerin sınırlı ilgisini yansıtıyordu. Bu gözlemi, Faruk Doğan'ın pek çok üreticinin ancak son zamanlarda göstermeye başladığı zeytinyağı ka-

42 Örnek olması için karşılaştırın: Özge Samancı [ed.], "1835 Yılına Ait bir Narh Defterine Göre İstanbul'da Bazı Gıdaların Fiyatları," Yemek ve Kültuir, 17, 2009, s. 56-60.

43 Faruk Doğan, Osmanh Devletinde Zeytinyağı Üretimi, s. 234.

44 Zeki Arıkan, "Osmanlı İmparatorluğunda İhracı Yasak Mallar [Memnu Meta] Prof. Dr. Bekir Kütükoğlu’na Armağan, İstanbul: İstanbul Üniversitesi Edebiyat Fakültesi, 1991, s. 279-307; Boulanger, Marseille, s. 45. 
litesine asgari ilgi gözlemiyle karşllaştırabiliriz. Özellikle yerel Bey’in pazarlamada kimi zaman kilit rol oynadığı Tunus vilayetinde, üreticilerin kaliteli zeytinyağı satışından gelecek kârın, kendi ceplerine değil de Bey'in hazinesine gideceğini düşünmüş olmaları da mümkündü.

Fikret Yllmaz, Edremit Bölgesi için göstermiş olduğu zeytinliklerin genişlemesinin temelde büyüyen nüfusun aydınlatma ve sabun ihtiyacını karşılamaya hizmet ettiğini varsaymıştı. Onun perspektifinden bakacak olursak, 1500'lü ve 1600'lü yıllarda insanlar sıvı yağlar talep ettiklerinde, genelde susam yağına yönelmişlerdi. Fikret Yılmaz, susam yağının zeytin ve zeytin ürünleri kadar ciddiyetle incelenmesi önerisinde kesinlikle haklıdır: 1500'lerin ikinci yarısında, Kudüs bölgesi gibi geleneksel zeytin topraklarında bile susam, zeytinle rekabet halindeydi. ${ }^{45}$

Aynı zamanda, elimizdeki metinlerden biri, literatürde ender rastlanan bir bilgi kırıntısını ele veriyor; en azından 1700'lerde, Ege kıyılarında sofralık üzüm korunması için zeytinyağında tutulurdu. Bu tekniğin, eskiden bu amaçla kullanılan hardal tohumunun yerini ne zaman aldığını söylemek imkansız. ${ }^{46}$ Tüketicilerin, bu işlemin meyvenin tadını etkilediğini hissedip hissetmediklerini anlamak için herhalde biraz daha beklememiz gerekecek. Ancak 1700'lerde, İstanbul yakınlarında üzüm bağları olduğunu ve ürünün muhtemelen bu tür bir işlem görmeden pazara getirildiğini hatırlamamız gerekmektedir. ${ }^{47}$ Zeytinyağlı üzümün bu durumda ciddi bir rakibi varmış!

Aydınlatma konusuna geçelim: Zeytinyağının örneğini Kanuni Sultan Süleyman, Mekke'ye padişahın hediyesi olarak gönderdiğinde, zeytinyağının aydınlatma amacıyla kullanıldığını biliyoruz. Ama nispeten pahalı olan bu tip yağların, gündelik hayatta ne ölçüde kullanıldığını gerçekten bilmiyoruz. Özel evler bir padişahın kızı ya da şehzadenin doğumunun şerefine aydınlatıldığında ya da müminlere Ramazan ve büyük bayramları hatırlatmak için camiler mahyalarla süslendiğinde, ev sahipleri ve vakıf idarecileri daha ucuz yanıcı maddeler aramış olabilirler. Kimi zaman susam yağı, zeytinyağıyla neredeyse aynı maliyete sahip olduğundan, diğer tohum çeşitlerinden preslenerek elde edilen yağ çeşitleri [beziryağı] kullanışlı alternatifler olarak görülmüş olabilir. Zaten bu tür aydınlatmalar dış mekanlara yönelik olduğundan, düşük kaliteli yağların kokuları çabuk dağılırdı. Ama bunların tümü spekülasyondan ibaret; belki de varlıklı vakıfların bazı ekâbirleri ve/ya da idarecileri zenginliklerini zeytinyağı yakarak sergilemek istemiş olabilirler. Kim bilir?

45 Yılmaz, "XVI. Yüzyılda Tarımsal Değişim,” s. 36-42.

46 Suraiya Faroqhi, "Supplying Seventeenth -and Eighteenth- Century Istanbul with Fresh Produce" Nourrir les cités de la Méditerranée, antiquité-temps modernes içinde; yayına hazırlayan Brigitte Marin ve Catherine Virlouvet, Paris: MMSH and Adrien Maisonneuve, 2003, s. 273-301, bkz. s. 296.

47 Domenico Sestini, Opuscoli del Signor Abbate Domenico Sestini, Florence, 1785, s. 46-49. 
En sonunda, 1800'lerin ikinci yarısının bir anında ve sonra da XX. yüzyılda, zeytinyağının sadece tohumlardan preslenen diğer yağların değil ama tereyağının da önüne geçerek en revaçtaki yemeklik yağ haline nasıl ve neden geldiği sorusu hâlâ cevapsız kalıyor. Zeytinyağının, doymamış yağ olarak bir avantajı olduğu kesin olmakla birlikte, tıp eğitimi almamış insanlar arasında bu özel sağlık kaygısının ancak son yirmi, otuz yılda ön plana çıkmış olduğu da unutulmamalı.

Çeviri: Ali Çakıroğlu 
